\title{
Embedded Sensor Technology Evaluation
}

Federal Manufacturing \& Technologies

C. J. Kennedy

KCP 613-8690

December 2009

Final Report

Approved for public release; distribution is unlimited.

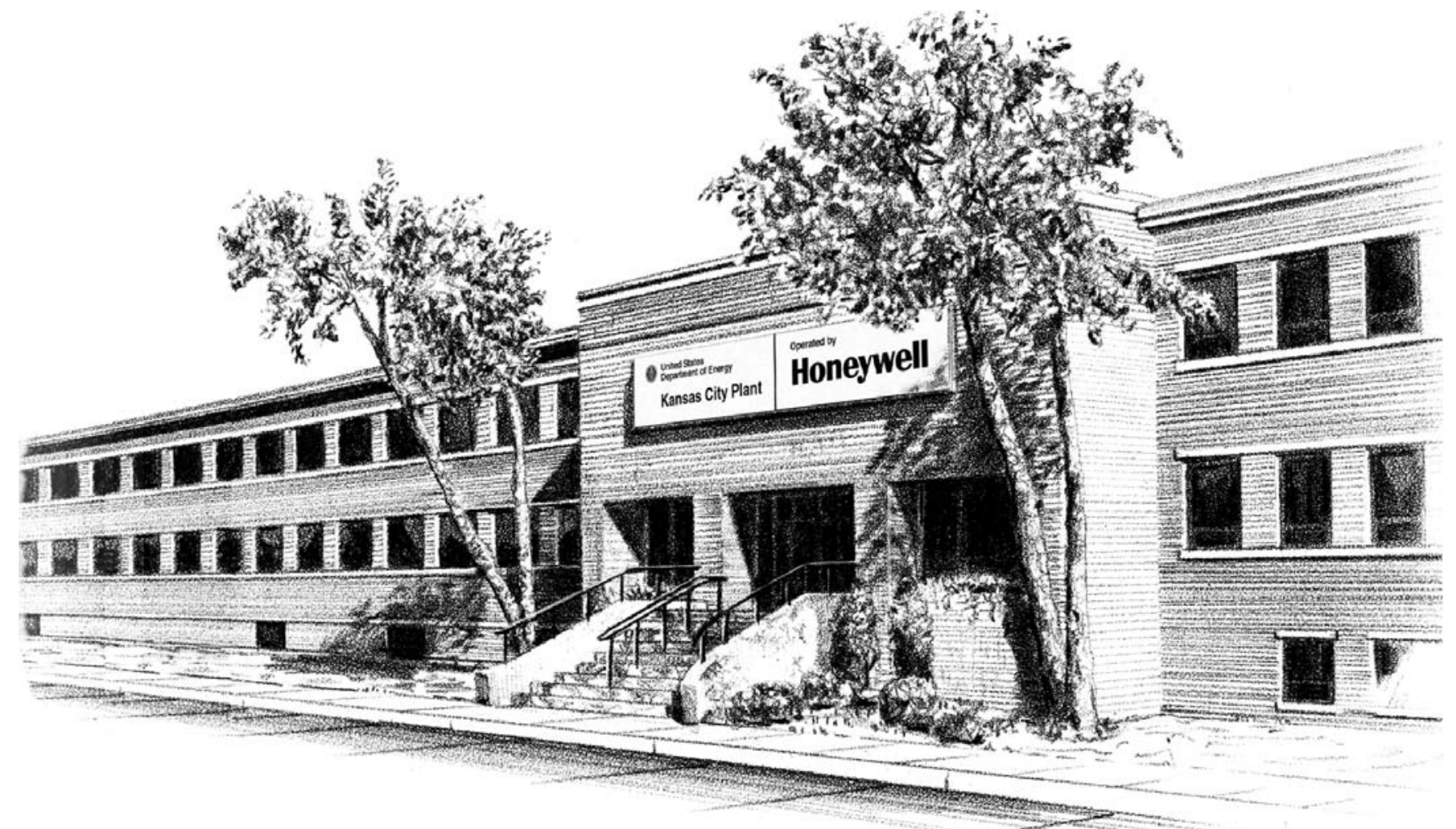

Prepared under prime contract DE-ACO4-01AL66850 for the

United States Department of Energy 


\section{DISCLAIMER}

This report was prepared as an account of work sponsored by an agency of the United States Government. Neither the United States Government nor any agency thereof, nor any of their employees, makes any warranty, express or implied, or assumes any legal liability or responsibility for the accuracy, completeness, or usefulness of any information, apparatus, product, or process disclosed, or represents that its use would not infringe privately owned rights. Reference herein to any specific commercial product, process or service by trade names, trademark, manufacturer, or otherwise, does not necessarily constitute or imply its endorsement, recommendation or favoring by the United States Government or any agency thereof. The views and opinions of authors expressed herein do not necessarily state or reflect those of the United States Government or any agency thereof.

All data prepared, analyzed and presented has been developed in a specific context of work and was prepared for internal evaluation and use pursuant to that work authorized under the reference contract. Reference herein to any specific commercial product, process or service by trade name, trademark, manufacturer, or otherwise, does not necessarily constitute or imply its endorsement, recommendation or favoring by the United States Government, any agency thereof or Honeywell Federal Manufacturing \& Technologies, LLC.

Printed in the United States of America.

This report has been reproduced from the best available copy.

Available to DOE and DOE contractors from the Office of Scientific and Technical Information, P.O. Box 62, Oak Ridge, Tennessee 37831; prices available from (865) 576-8401, FTS 626-8401.

Available to the public from the National Technical Information Service, U.S. Department of Commerce, 5285 Port Royal, Rd., Springfield, Virginia 22161, (703) 487-4650.

A prime contractor with the United States Department of Energy under Contract Number DE-AC04-O1AL66850

\author{
Honeywell Federal Manufacturing \& Technologies \\ P.O. Box 419159 \\ Kansas City, Missouri, 64141-6159
}




\title{
Honeywell
}

KCP-613-8681

Distribution Category UC-42

Approved for public release; distribution is unlimited.

\section{Embedded Sensor Technology Evaluation}

\author{
C.J. Kennedy \\ December 2009
}

Final Report

C.J. Kennedy, Project Leader 



\section{Contents}

Section Page

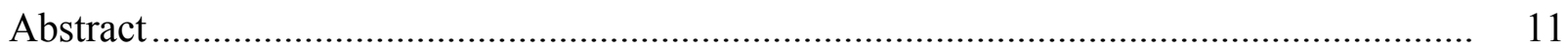

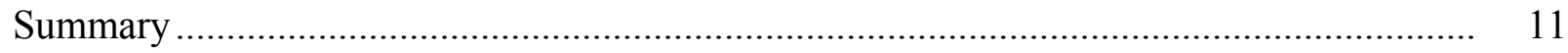

Discussion ...................................................................................................... 11

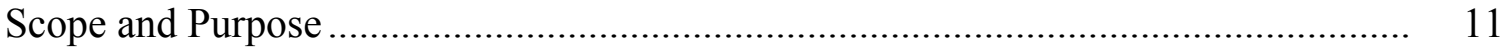

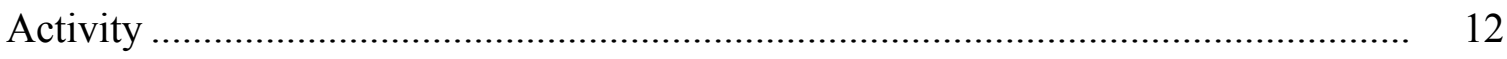

Bragg Grating Demodulation Systems ............................................... 12

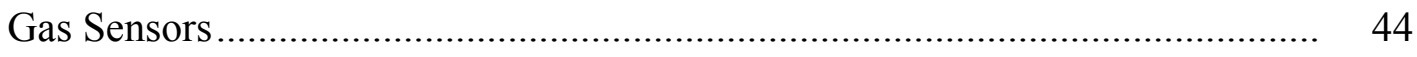

Displacement and Time of Arrival Sensors .............................................. 51

Fiber Optic COTS Sensors................................................................ $\quad 70$

Fiber Optic Connector Systems …................................................... 78

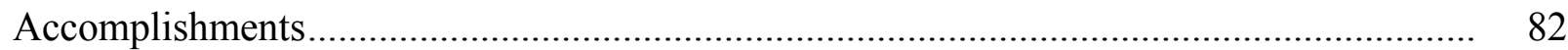

Appendices

A. COTS Hermetic Fiber Optic

Connector Specifications .......................................................................... 83

B. Fiber Optic Sensor

Shock and Vibration Data................................................................... 96 


\section{Illustrations}

Figure Page

1 MEMS Component of AXSUN 1 .............................................................. 13

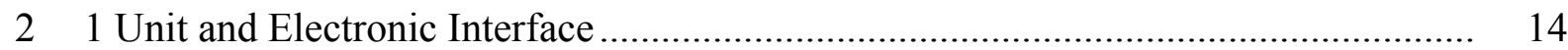

3 Normal Probability Plot Showing

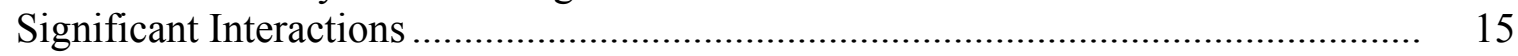

4 Pareto Chart Showing Significant Interactions ............................................. 15

5 Interactive Plot of Temperature,

Wavelength and Power ................................................................................. 16

6 Main Effects Plot Showing Standard Deviation ............................................. 16

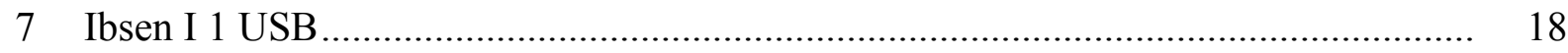

8 Ibsen and Bayspec Fiber

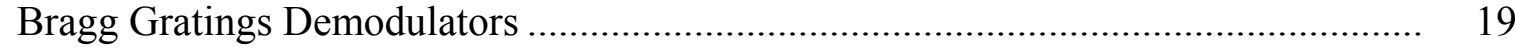

9 Stability Results for Ibsen

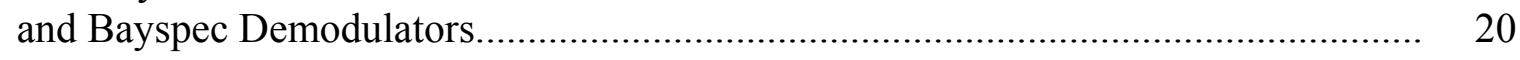

10 Bragg Grating Demodulators with Fiber Amplifier.............................................. 21

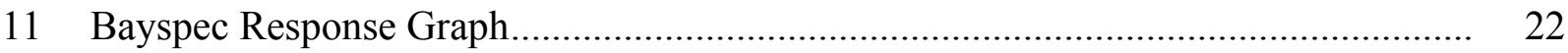

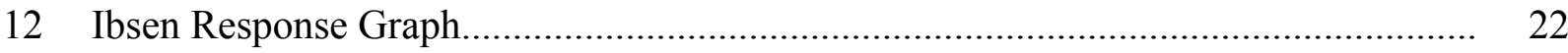

13 Fiber Sensors on Cantilever Beam........................................................................ 23

14 Fiber Bragg Grating in Stainless Tube............................................................ 24

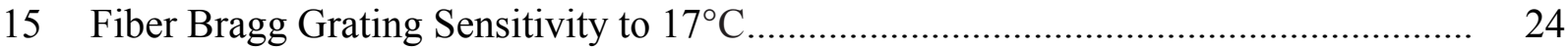

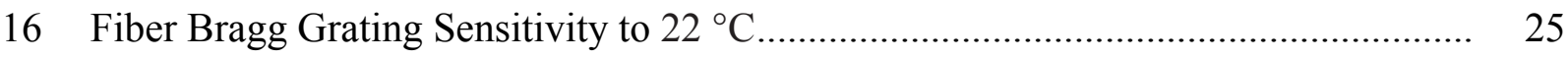

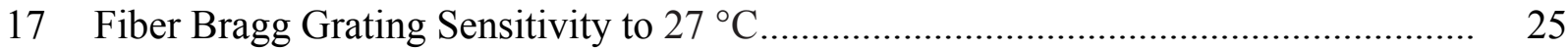

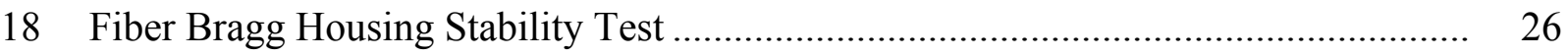

19 Single Mode Fiber Glass Sealed to Kovar Ferrule ............................................. 27 
20 Compact Tension With a Bragg

Grating and Conventional Sensor ......................................................................... 28

21 Precision Crack Growth Monitoring ........................................................................ 28

22 Fiber Laser Ultrasonic Sensor............................................................................ 29

23 Fiber Laser Ultrasonic Detector System .................................................................. 29

24 Ultrasonic Signal from Crack Growth in Kovar ..................................................... 30

25 Signal from Bragg Fiber Laser

in Kovar Compact Tension .................................................................................. 31

26 Bragg Grating Signal from

Delrin Compact Tension .................................................................................. 31

27 Fitel Fusion Splicer ................................................................................... 33

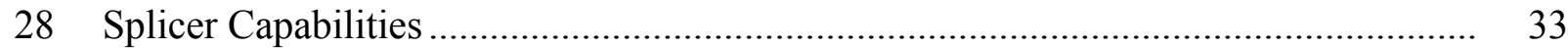

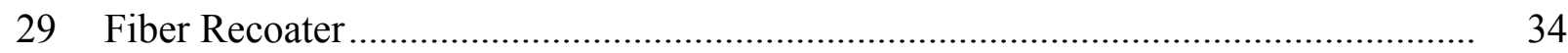

30 Wavelength Display of 5 Grating in Series .............................................................. 34

31 Optical Backscatter Reflectometer (OBR) ............................................................ 35

32 Tensile Test of Single Mode Fiber, 475 Microstrains

33 Tensile Test of Single Mode Fiber, 660 Microstrains

34 Tensile Test of Single Mode Fiber, 5000 Microstrains

35 Tensile Test of Single Mode Fiber, 30 Microstrains

36 Multiple Gauge Length of Strained Fiber Section ................................................. 38

37 Demodulation of $1527 \mathrm{~mm}$ Bragg Gratings............................................................... 40 
38 Demodulation of 1537 mm Bragg Gratings............................................................ 40

39 Demodulation of $1547 \mathrm{~mm}$ Bragg Gratings.............................................................. 41

40 Demodulation of $1557 \mathrm{~mm}$ Bragg Gratings............................................................ 41

41 Demodulation of $1567 \mathrm{~mm}$ Bragg Gratings............................................................ 42

42 OBR Measured Strain Vs. Fiber

Bragg Grating Readings................................................................................ 43

43 COTS Components for Interfacing to Fiber Optics................................................... 45

44 VCSEL Laser Diode Controller and Detector .......................................................... 46

45 Hollow Fiber Gas Cell ............................................................................................ 4

46 Sensor Response to Carbon Dioxide........................................................................ 47

$47 \quad$ Stainless Steel Plug....................................................................................... 48

48 Fiber Bonded to Stainless Steel Plug ……………................................................ 48

49 Stainless Steel Gas Cell with Hollow Wave Guide ..................................................... 49

$50 \quad$ Bolt 1 Hermetic Feed-Through............................................................................... 49

$51 \quad$ FO1 Hermetic Feed-Through......................................................................... 50

52 Dimensions of Bolt 1

Hermetic Feed-Through............................................................................ 50

53 Dimensions of FO1

Hermetic Feed-Through..................................................................................... 51

54 "In Line" 90-Degee and

"Bent Fiber" Displacement Sensors ........................................................................ 53

55 Performance of the "In Line" Displacement Sensor ...................................................... 54

$56 \quad$ Small Diameter Loops in Multimode Fiber …………………................................. 54

57 Perpendicular Time of Arrival Sensor (PTOA) ………........................................... 55 
$58 \quad$ PTOA Installed in a Simulated Next Assembly ...................................................... 56

59 PTOA in the up Position (For Transport) …………............................................. 57

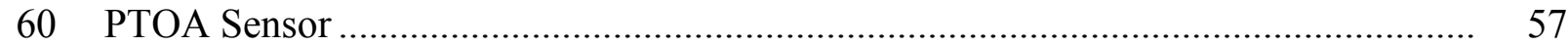

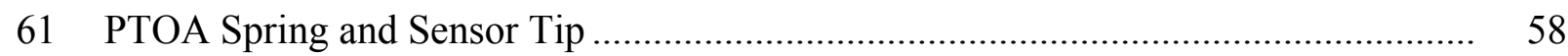

62 Tube Assembly Fixture ..................................................................................... 58

63 Sleeve to Tube Alignment Fixture ……………….................................................... 59

64 Sleeve to Tube Alignment Fixture (Close-Up View) ................................................ 59

65 Epoxy Holding Fiber Within ST Connector ........................................................... 60

66 PTOA Assemblies Attached to ST Connectors …………………………................... 61

67 PTOA Protected for Polishing by a Plastic Tube........................................................ 61

68 PTOA Attached to the Polishing Fixture ………….............................................. 62

69 PTOA ST Connector Being Polished ………………........................................... 62

70 Visible Light Transmission Through the PTOA Polished Fiber........................................................................................ 63

$71 \quad$ PTOA Sensor Tip Alignment Fixture _.................................................................. 64

72 PTOA Sensor Tip Alignment Fixture (Close-Up View) ............................................ 64

73 PTOA Sensor Tip Being Bonded (Close-Up View) ..................................................... 65

74 PTOA Sensor Tip Being Bonded in Place (Close-Up View) ..................................... 66

75 Self-Check Test Set-Up Configurations

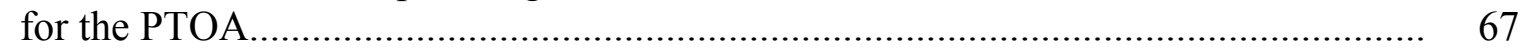

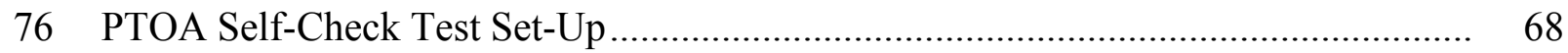

77 Temperature Sensors..................................................................................... 71

78 Temperature Sensor Results .............................................................................. 


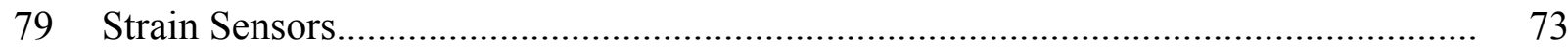

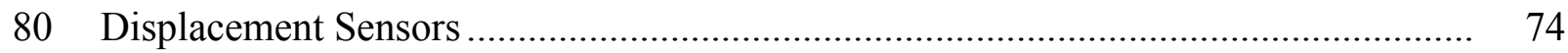

81 Pro-Engineer Model of Text Fixture........................................................................

82 Component Placement Within Text Fixture .................................................... 77

83 Miniature MT Optical Assembly (MMTOA) ................................................... 79

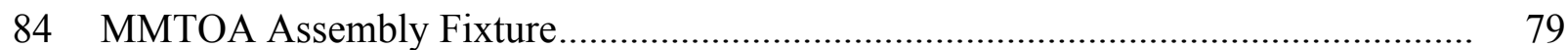

85 Flip-Chip MMTOA Optical Efficiency Calculations .......................................... 79

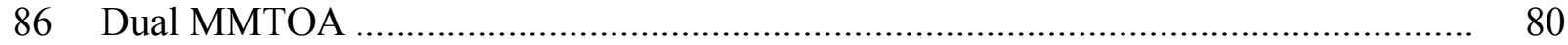

87 Right Angle MT and Normalized Output ................................................. 81

\section{Tables}

Number Page

1 Temperature, Power and Wavelength

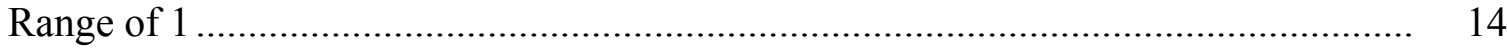

2 Gauge Length and Loose Fiber

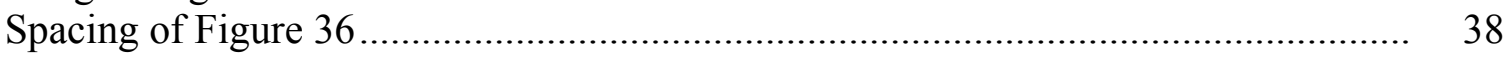

3 Typical Measurements with Various Gas Concentrations....................................... 44

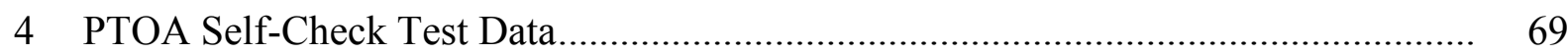




\begin{abstract}
Fiber Sensors are poised to be used in future LEPs. The three primary vehicles for fiber sensors are Department 1, Joint Test Assembly (JTA), and Shelf Life (SL). The National Security Enterprise (NSE) community plans to incorporate optical sensors or systems into these vehicles. Additionally, hermetic sealing of optical systems is required if optical technology is to be integrated into LEP and future weapons applications. Hermetic seals will reduce the long-term risk of contamination which can degrade or incapacitate optical components. This study was funded through the Kansas City Plant's (KCP) ESC work package between 2007 and 2009 to develop optical sensors, identify commercial fiber sensors and hermetic connectors, and qualify these sensors against likely weapon lifetime environments.
\end{abstract}

\title{
Summary
}

Bragg grating demodulation systems were analyzed, fiber sensors and hermetic connectors were evaluated, and optical sensors were designed to detect outgassing and displacement. In addition, a process for performing environmental testing on optical fibers and sensors was established. This process involves temperature cycling, helium leak testing, and shock and vibration at up to $5000 \mathrm{~g}$ 's. Bragg grating demodulators were compared in recognition that future weapon systems will require miniature data reduction capabilities. Temperature, strain, and gas sensors were researched in order to provide better predictive aging models on the life expectancy of components. Time of Arrival (TOA) and Miniature MT Optical Assembly's (MMTOA's) were designed and built to monitor shock wave propagation of High Explosives (HE). Commercial fiber optic sensors were investigated as part of the site-wide objective of Lean development and evaluation of existing design solutions. Fiber optic sensors offer several advantages over traditional sensors such as immunity to EMI and non-contact capabilities. The technologies described here will require ruggedization and continued refinement before they can be implemented in future systems.

\section{Discussion}

\section{Scope and Purpose}

The purpose of this project is to team with LLNL, LANL, SNL, PX, SRS and Y-12 to develop, characterize, ruggedize, and ultimately field, fiber optic sensor systems for embedded surveillance of future weapon systems. These include temperature, strain, gas, displacement, crack, and shock sensors. The two primary advantages of fiber optic sensors over more traditional methods of monitoring are immunity to EMI and the ability to be non-contact. When used in their final application, these fiber sensors will require feed-throughs. Additional scope is focused on evaluation and industrial review of hermetic fiber optic feed-throughs. Prototype glass-to-metal seals were fabricated. Fiber optic stripping, fusion splicing, and recoating were acquired and evaluated. Gas sensing (CO2) using infrared absorption through hollow fibers was investigated. Shock sensors, for LANL, were designed and fabricated. Fiber optic connector 
systems will be included in this effort as an enabling technology. This project is guided by and worked in collaboration with the Advanced Embedded Sensor-Joint Working Group (AESJWG). This working group presently includes LANL, LLNL, SNL, Honeywell FM\&T, PX, SRS and $\mathrm{Y}-12$.

\section{Activity}

\section{Bragg Grating Demodulation Systems}

Embedding fiber optic strain sensors in weapon systems will require miniature data reduction capability that can translate the optical signatures into usable electronic data. Two laboratory grade and two miniature-Bragg grating demodulators were evaluated as potential candidates. The laboratory systems were a Micron Optics 1 and a Luna Technology Optical Backscatter Reflectometer. The miniature demodulators include an AXSUN Technology 1 unit and an Ibsen Technology spectrometer, both engineered for Bragg demodulation.

The Micron Optics 1 is a laboratory grade instrument capable of scanning up to 512 sensors on 16 channels at 250 Hertz. This is a rack panel instrument that could be wheeled up to weapons in storage and connected to take periodic strain and temperature measurements. It could then be moved to nearby weapons and the cycle repeated. The 1 is a very stable and reliable system that has been in use by the Department of Defense (DoD) and private industry for some time. The purpose of the acquisition of this device was to have a laboratory standard that the team could compare the new miniaturized demodulators to. A Burleigh Wavemeter and HP Optical Spectrum Analyzer were used to cross check the 1 with good results.

A much tougher problem is to measure the Bragg grating wavelength in a flyable system where miniaturization, integration, low current draw, and durability are important considerations. Two commercial off-the-shelf (COTS) miniature demodulators were acquired for evaluation. The first is a Micro-Electro-Mechanical Systems (MEMS) based frequency measuring device from AXSUN Technologies. This system runs off of a 3.3 volt DC supply and has a serial and dualport RAM (DPRAM) interface. Binary code commands are furnished by the vendor and a custom Labview program was written to evaluate this demodulator. A Six Sigma analysis of the AXSUN unit provided an objective analysis of its capabilities.

The following commercial demodulators were evaluated:

Demodulator

AXSUN 2

Bayspec 1

Ibsen 1

FISO

Opsens

Neoptix

LUXTRON fluoroptic

\section{Measurement}

Strain

Strain

Strain

Strain, Temp

Strain, Temp

Temperature

Temperature
Sensor type

Bragg Grating

Bragg Grating

Bragg Grating

Fabry-Pérot

Fabry-Pérot

Gallium Arsenide

Fluorescent Decay 


\section{AXSUN 1}

A Design of Experiment (DoE) tool was utilized to evaluate the statistical output of a commercial Bragg interrogator. The unit evaluated was a model 1 from AXSUN Technologies (Livermore, CA). The 1 is a MEMS-based spectrometer capable of interfacing to DPRAM or 3. It was engineered specifically to read out Bragg grating strain sensors for the oil industry. It is a superb example of miniaturization with "value added engineering" to solve the specific Bragg grating problem. An issue was noted when comparing the output of the AXSUN unit with another commercial product, the Micron Optic 1 Demodulator. The 1 system is close to a laboratory standard for this application. Using third party software, the 1 unit has superior stability and can read out stable measurements in picometers. However, it also is a rack mount sized device and is not embeddable due to its size and energy consumption. Repeated data collection with the AXSUN unit showed a variation of 0.02 nanometers in all repetitive measurements.

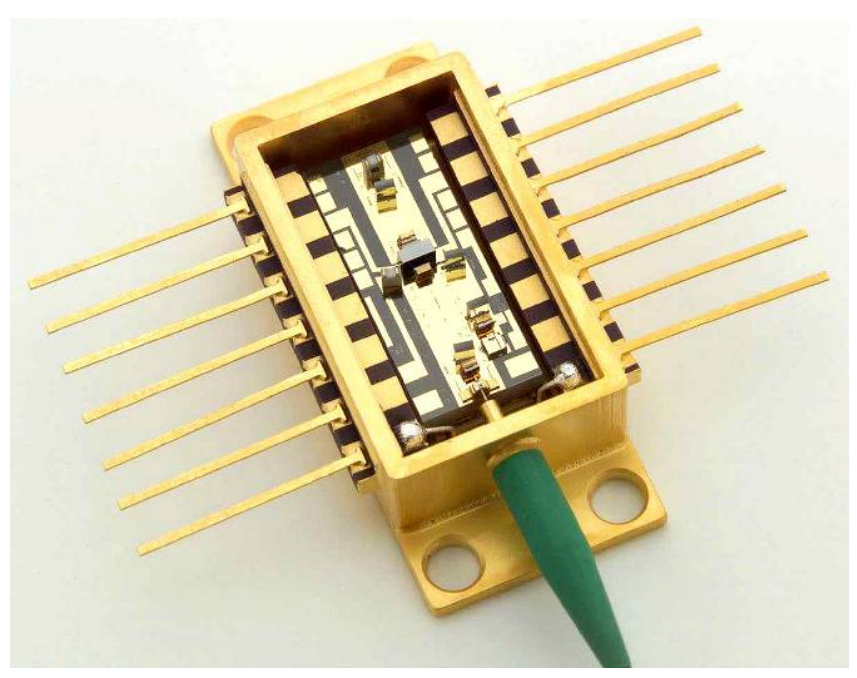

Figure 1. MEMS Component of AXSUN 1

The light source for the MEMS spectrometer was fabricated from a pumped fiber amplifier to provide a broadband 1520 to 1570 nanometer signal. This broadband source was then reflected off of two Bragg gratings to provide a spectral signature for the MEMS device to measure. The Bragg gratings were connected, one at a time, and provided either a 1527 nanometer signal or a 1566 nanometer signal to the spectrometer. The gratings were mounted inside of a thermoelectrically controlled temperature unit that was mounted inside of an incubator oven maintained at $22^{\circ} \mathrm{C}$.

The result is that the team could select the temperature, wavelength, and power level of the signals. A 3 X2 factor design selected the following options:

$\begin{array}{lll}\text { Temperature } & 20{ }^{\circ} \mathrm{C} & 40{ }^{\circ} \mathrm{C} \\ \text { Wavelength } & 1527 \mathrm{~nm} & 1566 \mathrm{~nm} \\ \text { PowerASE } & -60 \mathrm{dBm} & -50 \mathrm{dBm}\end{array}$




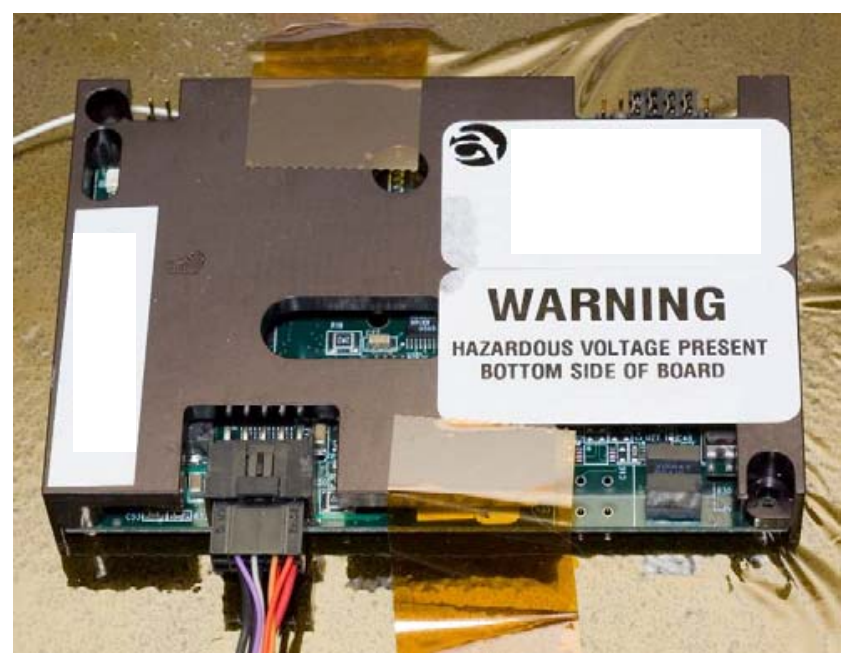

Figure 2. 1 Unit and Electronic Interface

The wavelengths used allowed testing at the extremes of the spectrometer. The temperature range was arbitrary similar to what would be considered an everyday plant environment. The power levels of the Amplified Spontaneous Emission (ASE) were adjustable and within the linear range of the amplifier. At each temperature, wavelength, and power level, five data points of the wavelength in nanometers were taken and their standard deviation entered as yield in the following experiment profile.

\begin{tabular}{|c|c|c|c|c|c|c|c|c|}
\hline & C1 & C2 & $\mathrm{C} 3$ & C4 & C5 & C6 & c7 & C8 \\
\hline & StdOrder & RunOrder & CenterPt & Blocks & TEMP & WAVELNGTH & POWER ASE & YIELD \\
\hline 1 & 2 & 1 & 1 & \begin{tabular}{r|}
1 \\
\end{tabular} & 40 & 1526 & $\begin{array}{r}-60 \\
\end{array}$ & 0.0607 \\
\hline 2 & 14 & 2 & 1 & 1 & 40 & 1526 & -50 & -0.0420 \\
\hline 3 & 4 & 3 & 1 & 1 & 40 & 1566 & -60 & -0.0113 \\
\hline 4 & 3 & 4 & 1 & 1 & 20 & 1566 & -60 & 0.0114 \\
\hline 5 & 1 & 5 & 1 & 1 & 20 & 1526 & -60 & 0.0135 \\
\hline 6 & 16 & 6 & 1 & 1 & 40 & 1566 & -50 & -0.0262 \\
\hline 7 & 11 & 7 & 1 & 1 & 20 & 1566 & -60 & 0.0417 \\
\hline 8 & 7 & 8 & 1 & 1 & 20 & 1566 & -50 & -0.0447 \\
\hline 9 & 6 & 9 & 1 & 1 & 40 & 1526 & -50 & -0.0506 \\
\hline 10 & 8 & 10 & 1 & 1 & 40 & 1566 & -50 & -0.0414 \\
\hline 11 & 5 & 11 & 1 & 1 & 20 & 1526 & -50 & -0.0319 \\
\hline 12 & 9 & 12 & 1 & 1 & 20 & 1526 & -60 & -0.0224 \\
\hline 13 & 12 & 13 & 1 & 1 & 40 & 1566 & -60 & -0.0037 \\
\hline 14 & 10 & 14 & 1 & 1 & 40 & 1526 & -60 & 0.0682 \\
\hline 15 & 15 & 15 & 1 & 1 & 20 & 1566 & -50 & -0.0354 \\
\hline 16 & 13 & 16 & 1 & 1 & 20 & 1526 & -50 & -0.0193 \\
\hline
\end{tabular}

Table 1. Eight Experiments Were Replicated one Time, in the Order Specified in Column 2 


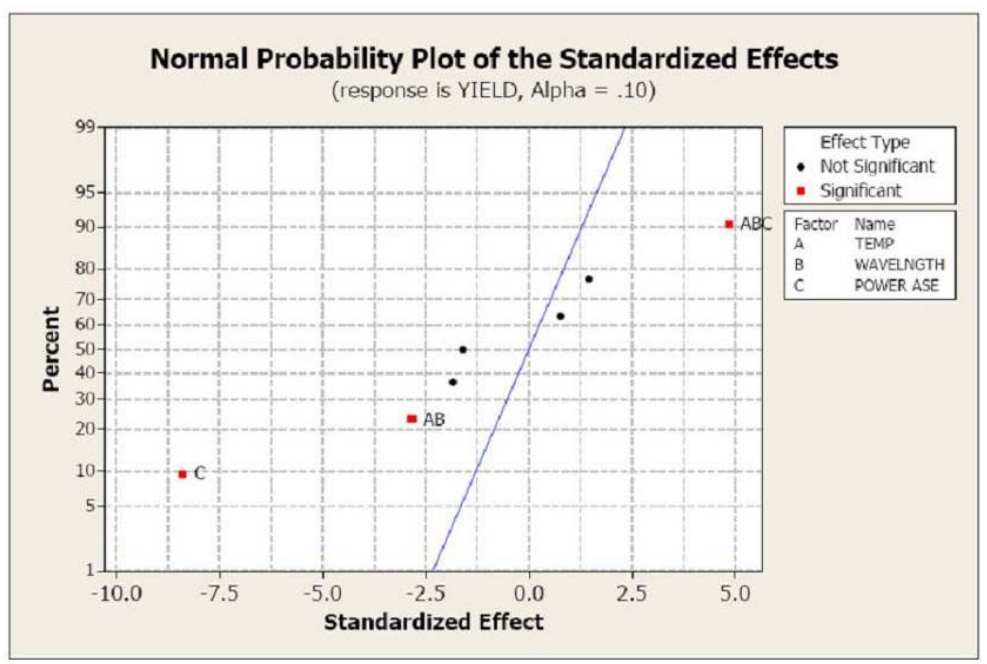

Figure 3. Normal Probability Plot Showing the Significant Interactions

The Power ASE is the most significant along with multiple factor interactions of Temperature* Wavelength and Temperature* Wavelength*PowerASE.

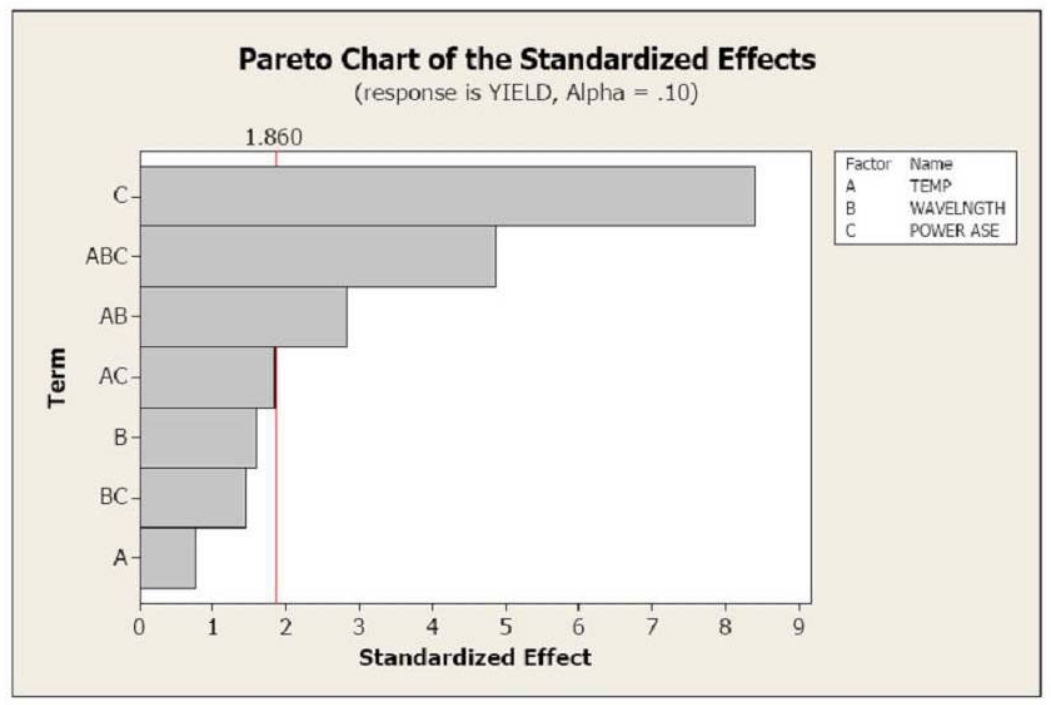

Figure 4. Pareto Chart adds Perspective to These Interactions 
The PowerASE component has significantly more effect than the other interactions. A more direct comparison between the three variables is shown in the Interaction Plot.

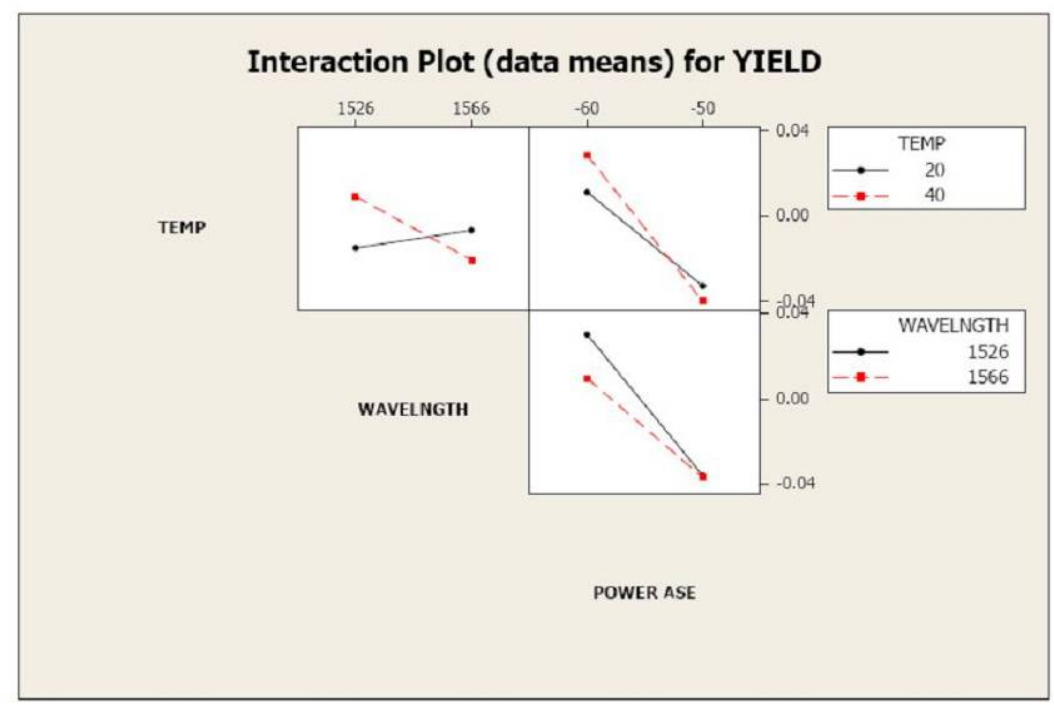

Figure 5. Interaction Plot Showing a More Direct Comparison Between the Three Variables

The temperature wavelength interaction is interesting but not surprising. A Bragg grating's wavelength is certainly determined by both temperature and mechanical strain not factored in this analysis. The critical point here is that temperature is one variable that the team does not have control of in the field, especially in embedded applications.

To minimize confusion, a second run was completed without the third order interactions. The main effects plot in this instance provides valuable insight into the three variables contribution to the standard deviation.

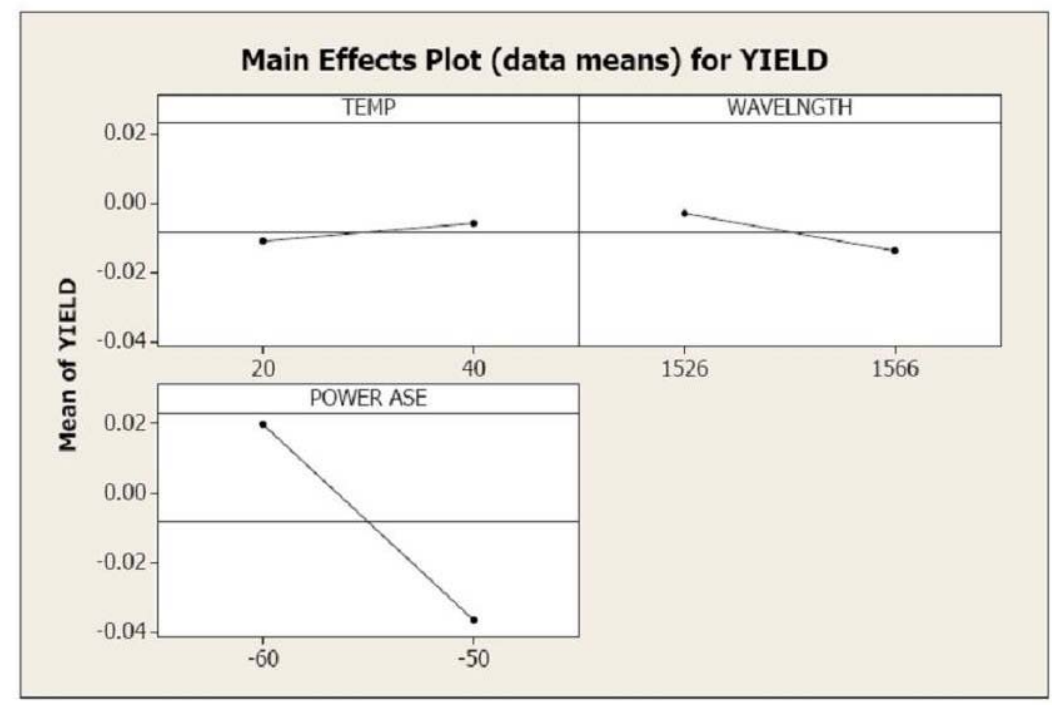

Figure 6. Main Effects Plot Showing Variables Contribution to Standard Deviation 
Clearly, the ASE power level has a significantly greater impact on the data spread than that shown in the three way interaction. There appears to be a minimum yield standard deviation around $-57 \mathrm{dBm}$. The DoE provides coefficients for the interaction that can be expressed in the following equation.

YIELD $=-2.1136+0.0737 *$ TEMP $+0.001157 * \lambda-0.00562 * \mathrm{P}_{\mathrm{ASE}}-4.75 \mathrm{e}-5 * \mathrm{TEMP} * \lambda$

If Temp $=20^{\circ} \mathrm{C}$ and $\lambda=1550$ nanometers, then

YIELD $=-0.319-0.00562 * \mathrm{P}_{\mathrm{ASE}}$

If the YIELD is minimized, than the standard deviation tends to zero

$\mathrm{P}_{\mathrm{ASE}}=-56.76 \mathrm{dBm}$

Therefore if the team set the PowerASE level to $-56.76 \mathrm{dBm}$ by adjusting the pump level of the fiber amplifier ASE source, out data should have a minimum standard deviation near the center of the spectrometer's wavelength range, 1550 nanometers. The above main effects plot also indicates that temperature and wavelength are not that significant a contributor to data spread. This conclusion is interesting theoretically, but the Bragg gratings will not all show the same power level. In fact, ten to one hundred gratings could be employed and each would assume the power level dictated by the gain curve of the fiber amplifier and also the reflectivity of each individual grating. Since gratings are manufactured one at a time, there is no reason to believe that their reflectivity will be equal or even similar on a linear scale.

An alternate approach to reduce the standard deviation, is to take the average of 100 readings at a constant PowerASE, $\lambda$, and temperature. Keeping the PowerASE, $\lambda$, and temperature the same, find the average of an additional 24 sets of 100 readings. This standard approach, suggested by $\mathrm{KCP}$, was implemented in the Labview data reduction program written at KCP for the Axsun 1. The results of this study are a standard deviation of less than $0.001 \mathrm{THz}$ and less than 0.009 nanometers. This analysis employed 10000 points of data. As the power level approached -56 $\mathrm{dBm}$, which occurred for the Bragg grating at 1567 nanometers, the standard deviation for wavelength reduced to less than 0.0012 , as predicted by minimizing the YIELD equation above.

The wavelength resolution, as in any digital system, is limited by the analog to digital conversion implemented in the Axsun 1. Prompting the Axsun 1 with a command to read digital peaks will return the frequency of the peaks in terahertz, but coded in hexadecimal. E.g. the Axsun 1 returns hex: 302D. 302D Hex converts to 12333 decimal. The frequency is derived by the formula $(12333 / 1000)+180=192.333$. Likewise, the next highest hex number available from the device is 302E. 302E Hex converts to 12334 decimal. Likewise, the frequency is $(12334 / 1000)+180=$ 192.334. The smallest frequency interval that can be read with this device is $0.001 \mathrm{THz}$.

Dividing the speed of light by the frequency, $192.333 \mathrm{THz}$, calculates the wavelength 1558.716 nanometers. Likewise, $192.334 \mathrm{THz}$ has a wavelength of 1558.708 nanometers. Therefore, the smallest wavelength interval that can be read with this device is 0.008 nanometers. This restriction is imposed by the spectrometer $\mathrm{A} / \mathrm{D}$ converter and cannot be improved through statistical means.

Raw data from the Axsun 1 resulted in a wavelength standard deviation of 0.018 nanometers for 150 consecutive readings from the Axsun 1 at $20^{\circ} \mathrm{C}$. By deploying DoE a power level was 
established to minimize the standard deviation. Also, massive statistical averaging techniques were employed to minimize the data spread. The result of this common statistical approach reduced the standard deviation of the wavelength spread to less than 1.2 picometers at the power adjusted YIELD minimum.

One future objective is to establish a level of statistical averaging that accomplishes an acceptable data spread with a minimum amount of data collection. This will be critical due to the time required to sample multiple readings from the Axsun 1. Using the statistical approach to acquire data within the precision needed required 10,000 data points. The same statistical approach was applied to reducing the number of data points taken and evaluating the precision of the measurement each time. Actual test data indicates that the same statistical approach can be applied to only 20 data points. This was possible because the physical limitations of the analog to digital converter artificially impose a boundary condition on the precision. That is, it is less than what it theoretically could be, even with statistical data analysis. This reduction from 10,000 data points to 20 data points could extend the life of the demodulator by a factor of 500 .

\section{Ibsen Technologies 1 and Bayspec 1}

The Ibsen 1 is a transmission diffraction grating implementation of an infrared fiber optic spectrometer. The unit interfaces, like the AXSUN unit, to a single board computer for data reduction. The interface is a USB port with software furnished by the vendor. The CCD detector and electronics are manufactured by Hamamatsu and a redesign of the spectrometer using transmission diffraction gratings was done by Ibsen. The team was able to achieve Bragg wavelength measurements repeatable to several picometers, without significant standard deviation. A Six Sigma analysis was not performed on this spectrometer, because the stability and repeatability of measurements did not seem to warrant the additional analysis. This unit is slightly larger than the AXSUN unit but the optical spectrometer can be separated from the electronics board allowing a distribution of smaller components.

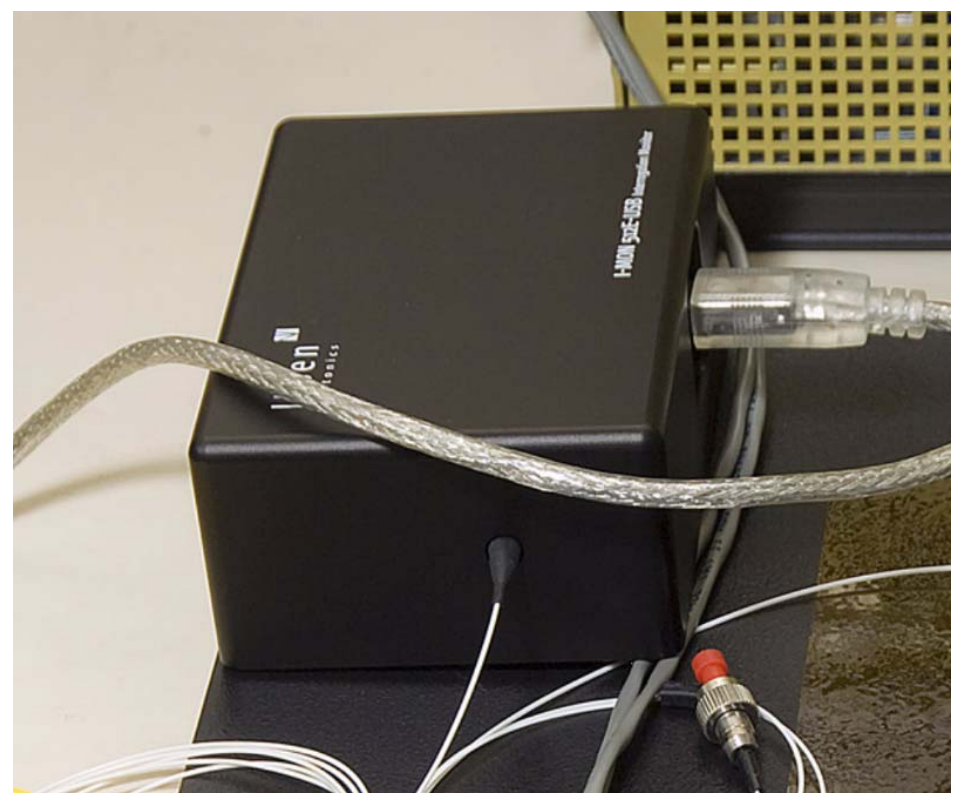

Figure 7. Ibsen 1 USB 
The Ibsen and AXSUN demodulators both measure strain by the monitoring wavelength change of a strained fiber Bragg grating. These gratings are produced by interferometric ultraviolet (UV) radiation of single mode fiber. The UV source wavelength is typically 266 nanometers in the UV. A double beam, or equivalent, arrangement produce interference fringes in the 5-to-9 micron core of germanium-doped photosensitive single mode fiber. The fringes create a permanent optical grating in the core of fiber, which reflects broadband light at a single wavelength. Straining the fiber produces a change in wavelength, which is typically measured by various types of spectrometers.

Long-term stability tests were run on the Bayspec and Ibsen demodulators. The strain gages were glass soldered to a metal strain fixture and the entire incubator was held at $40^{\circ}$ centigrade for months.

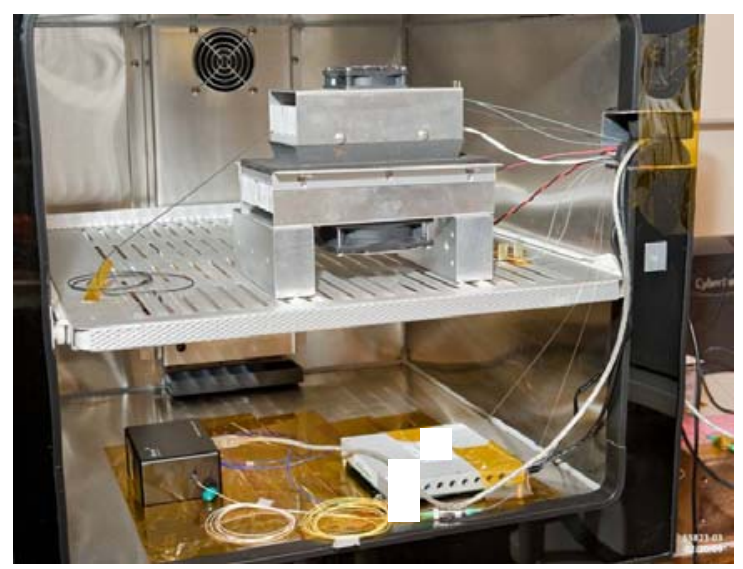

Figure 8. Ibsen and Bayspec Fiber Bragg Grating Demodulators, Lower Shelf, Inside a Temperature-Controlled Incubator. The Thermoelectric Controller, Top Shelf, Houses the Fiber Bragg Gratings

A commercial fiber amplifier was used as an ASE broad source to illuminate the fiber Bragg gratings. The reflected signals from the Bragg gratings were fiber routed to the Ibsen and Bayspec demodulators. The Bayspec unit required an external power source. The Ibsen unit is powered from the USB connection. Computer control and data acquisition of the Ibsen and Bayspec units was through a USB port. 


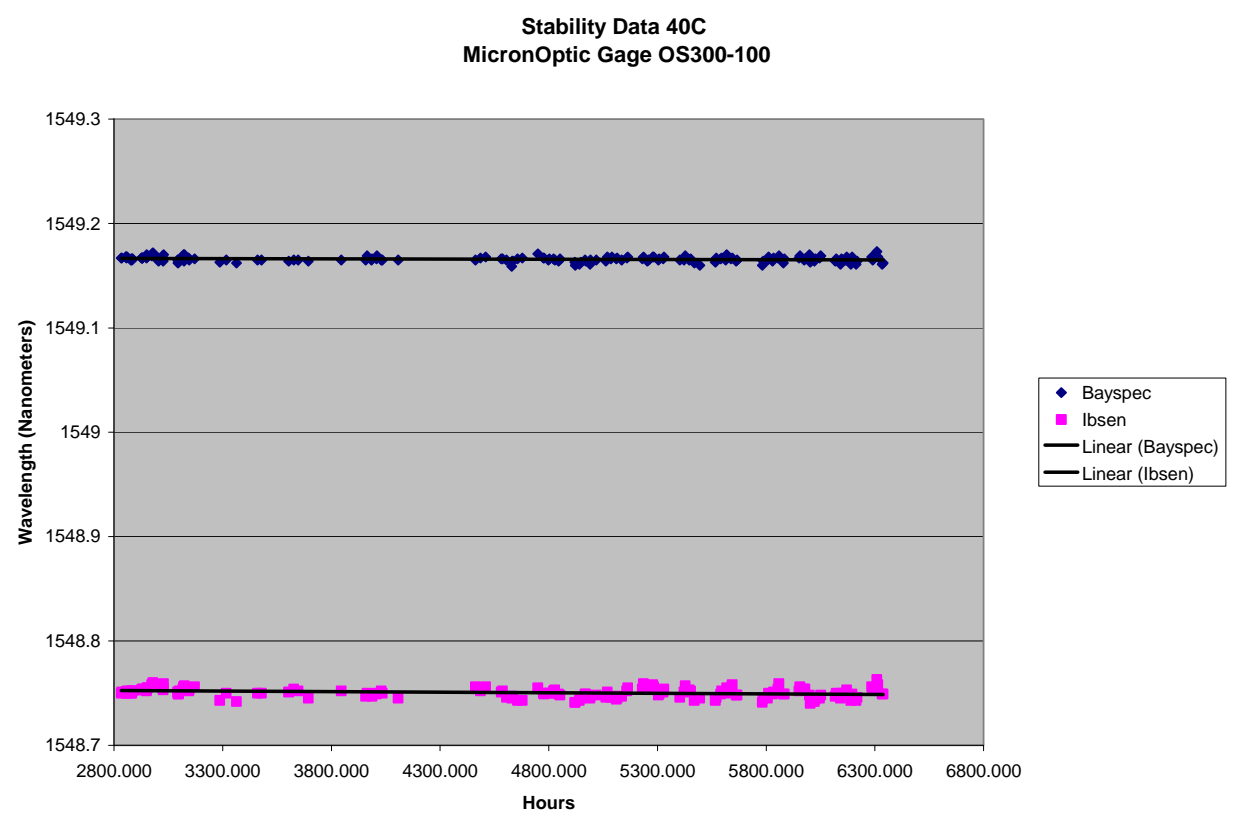

Figure 9. Stability Results for the Ibsen 1 and the Bayspec 1 Fiber Bragg Grating Demodulators

The standard deviation for the Bayspec was 2.3 picometers and the Ibsen was 4.3 picometers. The slightly better performance of the Bayspec unit was offset by a significant number of false readings captured over the 6,300 hour test. This problem was corrected by purchasing a new Bayspec unit with an updated USB driver that appeared to eliminate the problem under computer control; however it was not checked for stability. Both units had no trouble distinguishing adjacent signals if their wavelengths were sufficiently different.

\section{Strain Measurement using Brillouin Backscatter}

An optical backscatter reflectometer was purchased under another project. The instrument is manufactured by Luna Technologies. The Optical Backscatter Reflectometer is normally used for locating optical defects and interfaces in fiber optics and optical components. The vendor claims that their strain measurement software allows distributed strain and temperature measurement along the length of a continuous optical fiber. The software to accomplish this was purchased in November and a cursory look at its capability indicated serious potential for measuring strain or dislocations in HE by merely stretching a fiber throughout an assembly. This would be a state of the art capability for measuring distributed fiber in storage assemblies if it proves feasible. The system has been tested for observing interference fringes in Fabry-Pérot shock sensors, interfaces in short fiber lasers, and Bragg grating reflections. Preliminary tests have measured thermal distribution in distributed fiber optics. 
This project was initiated to evaluate the state of the art in Bragg Grating demodulator systems for embedded applications. Three commercial demodulators were evaluated. The demodulators are as follows:

\section{AXSUN 2}

Bayspec 1

Ibsen 1

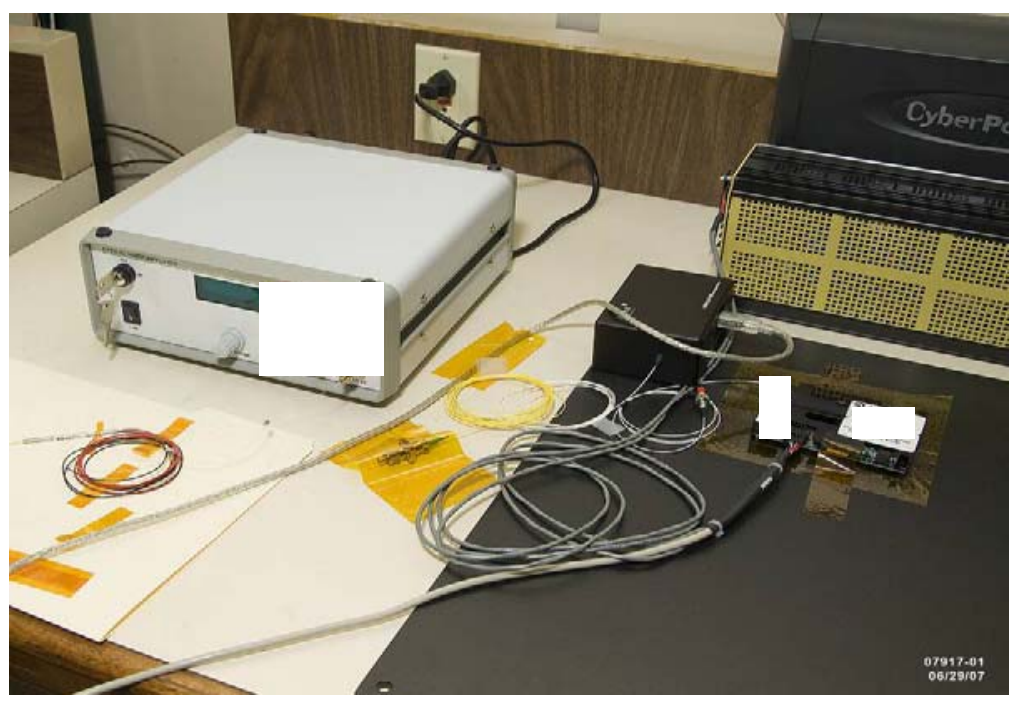

Figure 10. Ibsen and AXSUN Fiber Bragg Grating Demodulators with Fiber Amplifier ASE Source and Power

A commercial fiber amplifier was used as an ASE broad source to illuminate fiber Bragg gratings. The reflected signals from the Bragg gratings were fiber routed to the three demodulators. Both the AXSUN and the Bayspec unit require an external power source. The Ibsen unit is powered from the USB connection. Both the Ibsen and Bayspec units were controlled by external computer connections through the USB port. The AXSUN unit required a 3 link. Guidance provided by LANL, requested that the demodulators be evaluated for their capability to measure 5 microstrains over a 0 to 2,000 microstrain range and a stability analysis over time.

The AXSUN unit was the first to be evaluated. The resolution of the AXSUN demodulator did not approach that of the other two without significant software statistical averaging. Although the AXSUN unit might be perfectly suitable for certain embedded applications, the 5 microstrain requirement immediately eliminated it from consideration. The Ibsen and Bayspec were closely evaluated for resolution and stability requirements. In order to evaluate relative strain measurements in fine increments, a fiber Bragg grating was bonded to computer controlled staging and strained in $1 / 4$ micron increments from 0 to 2000 microstrain. 


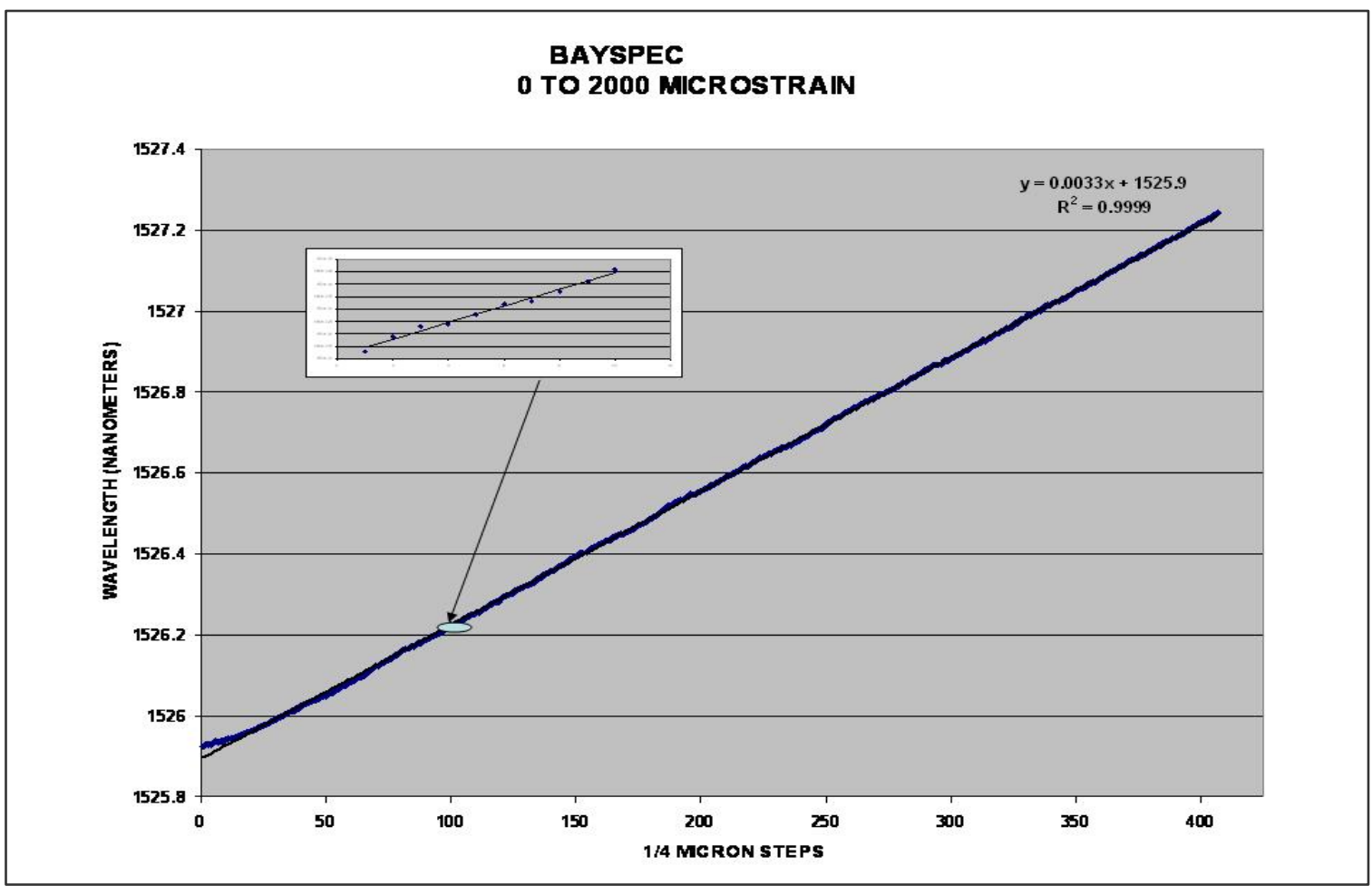

Figure 11. Bayspec Response From 0 to 2000 Microstrain in $1 / 4$ Micron Displacement Increments

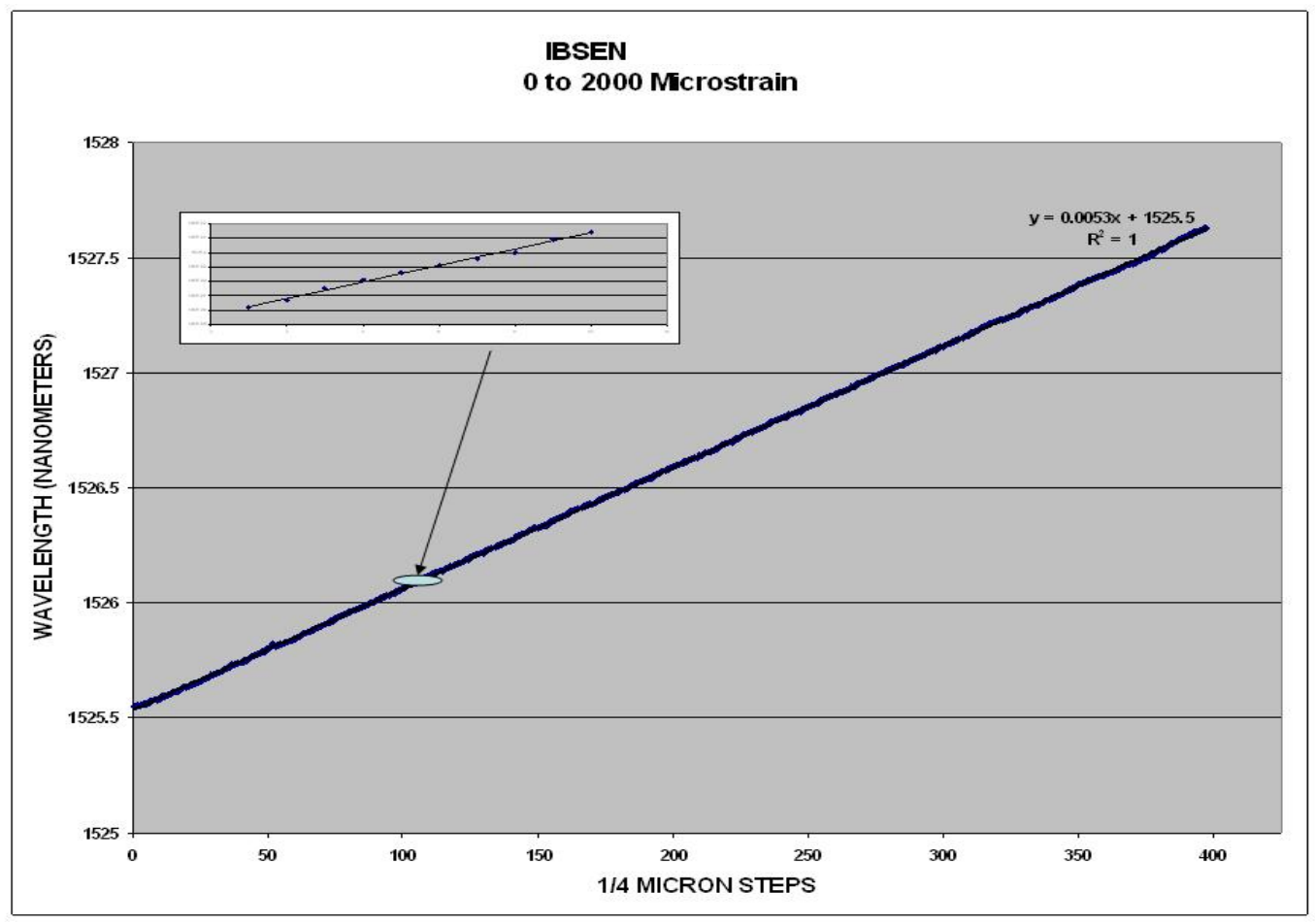

Figure 12. Ibsen Response from 0 to 2000 Microstrain in $1 / 4$ Micron Displacement Increments 
The computer staging employed was part of a Newport fiber alignment system with 0.1 micron positioning capability. The Newport auto-align system employs screw driven staging with moiré grid readout achieving high precision. However, the demodulator measurements in Figure 9 and 10 revealed a mechanical relaxation of the staging not previously recognized. The data was possible by very rapidly taking data at each $1 / 4$ micron increment prior to the relaxation movement.

To eliminate the mechanical relaxation issue, experienced with the loaded Newport staging, two Bragg gratings and a Fabry Pérot fiber sensor were attached to a loaded cantilever beam. In addition, an electrical strain gage was attached in the same location. The results were consistent with the load equation and demonstrated that 2000 microstrain is not an issue with the fiber optic sensors. To determine whether the demodulators could repeatedly measure 5 microstrains, a different technique was employed. A 30 millimeter stainless tube with a precision 160 micron bore was used to form a thermometer with the fiber Bragg grating, bonded at both ends.

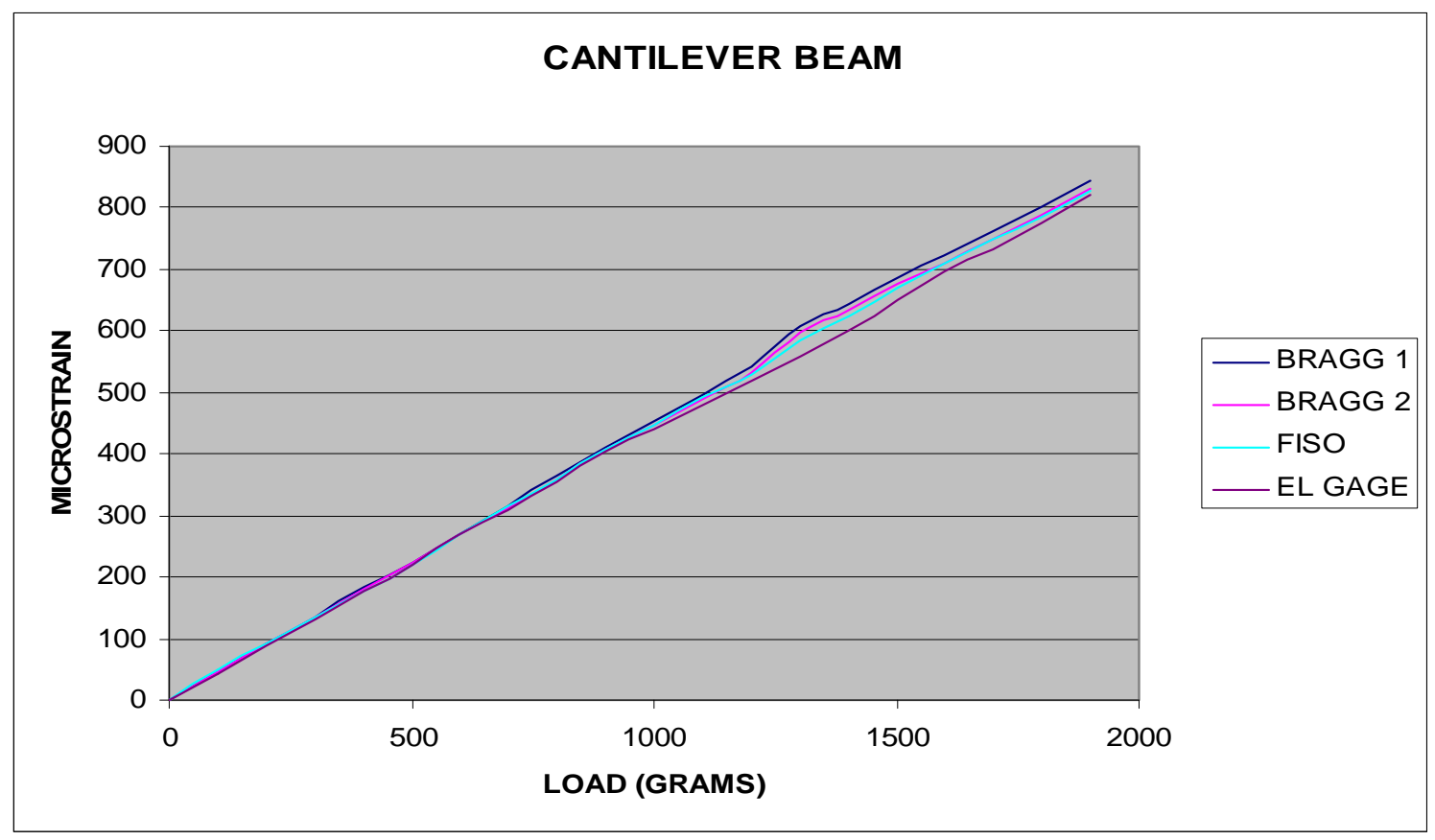

Figure 13. Fiber Sensors on Cantilever Beam

\section{Stainless Tube Thermometer}

A different technique was required to determine whether the demodulators could repeatedly measure 5 microstrains. A 30 millimeter stainless tube with a precision 160 micron bore was used to form a thermometer with the fiber Bragg grating bonded at both ends. The Stainless thermometer was then attached to a Melcor 1 thermoelectric control plate with an external Melcor controller. The Melcor TEC plate with thermometer was then placed inside a temperature controlled incubator in order to minimize room fluctuations. This way, the entire incubator could be at the same temperature as the thermometer. Incremental temperature changes of $0.29{ }^{\circ} \mathrm{C}$ on the TEC plate would provide 5 microstrains on the Bragg grating. Since the objective was to 
determine stability of the demodulator units, both the Bayspec and the Ibsen demodulators were placed inside the incubator. The 5 microstrain on the fiber Bragg gratings would produce the wavelength changes shown in Figures 12 through 14.

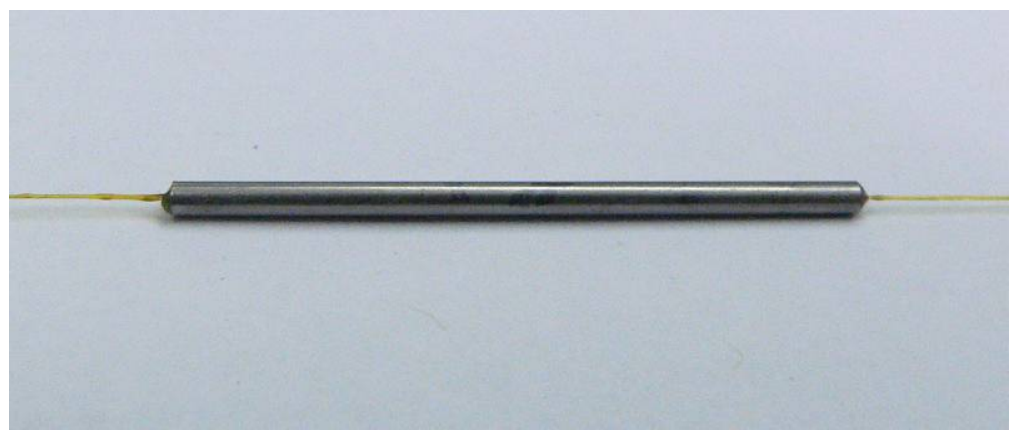

Figure 14. Fiber Bragg Grating in Stainless Tube From Minitool Inc

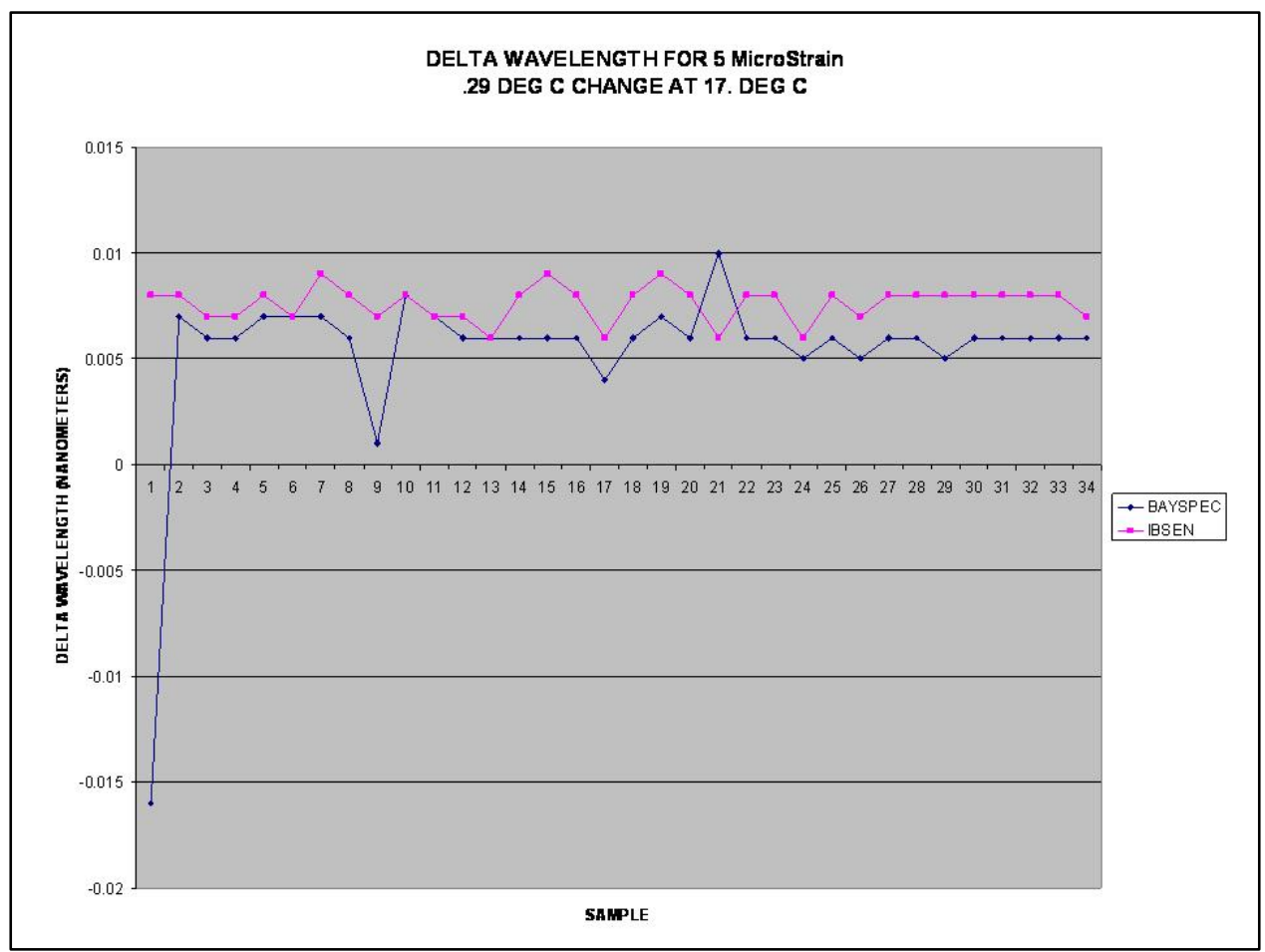

Figure 15. Fiber Bragg Grating Sensitivity to Temperature at $17^{\circ} \mathrm{C}$ 


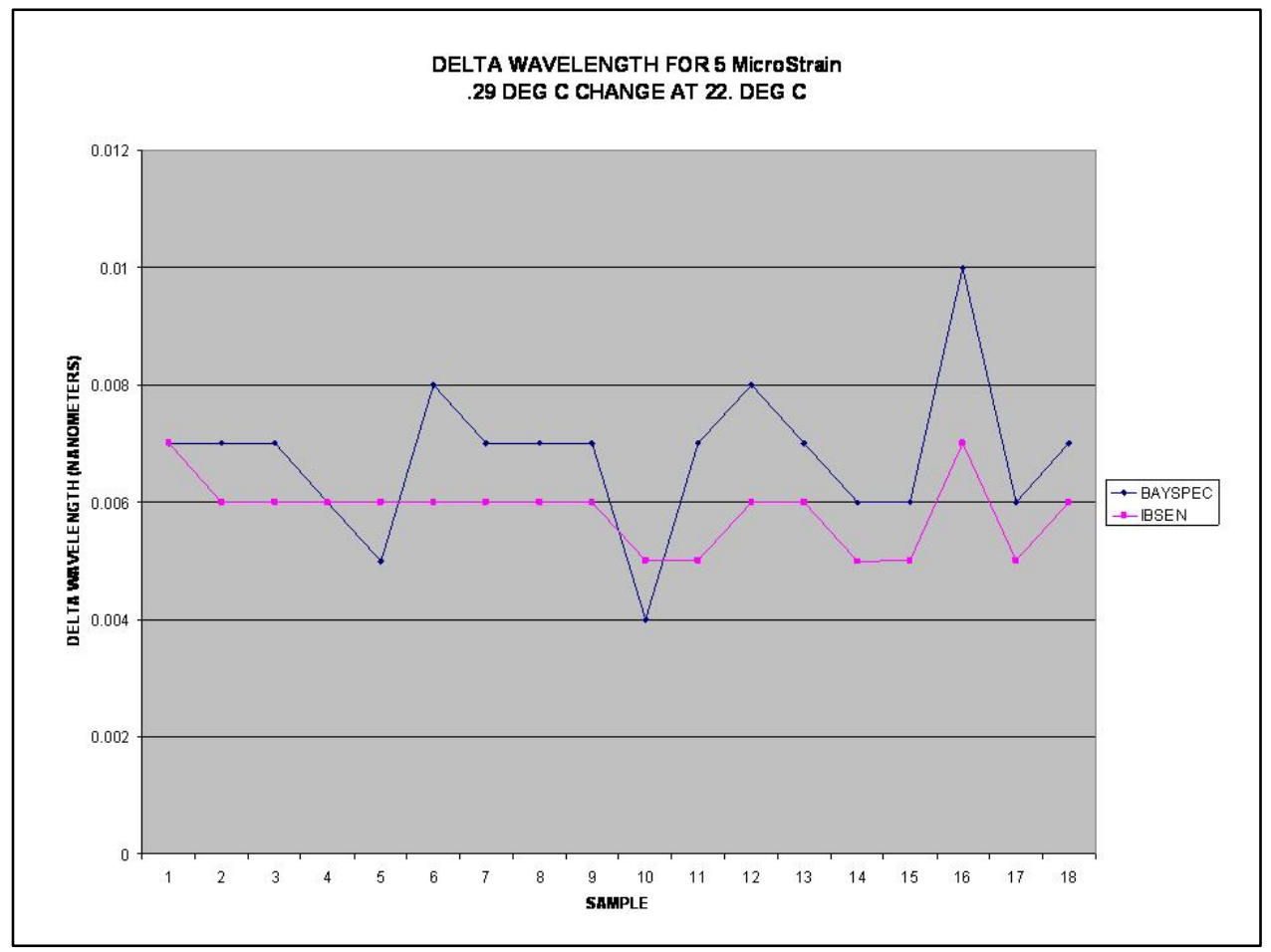

Figure 16. Fiber Bragg Grating Sensitivity to Temperature at $22^{\circ} \mathrm{C}$

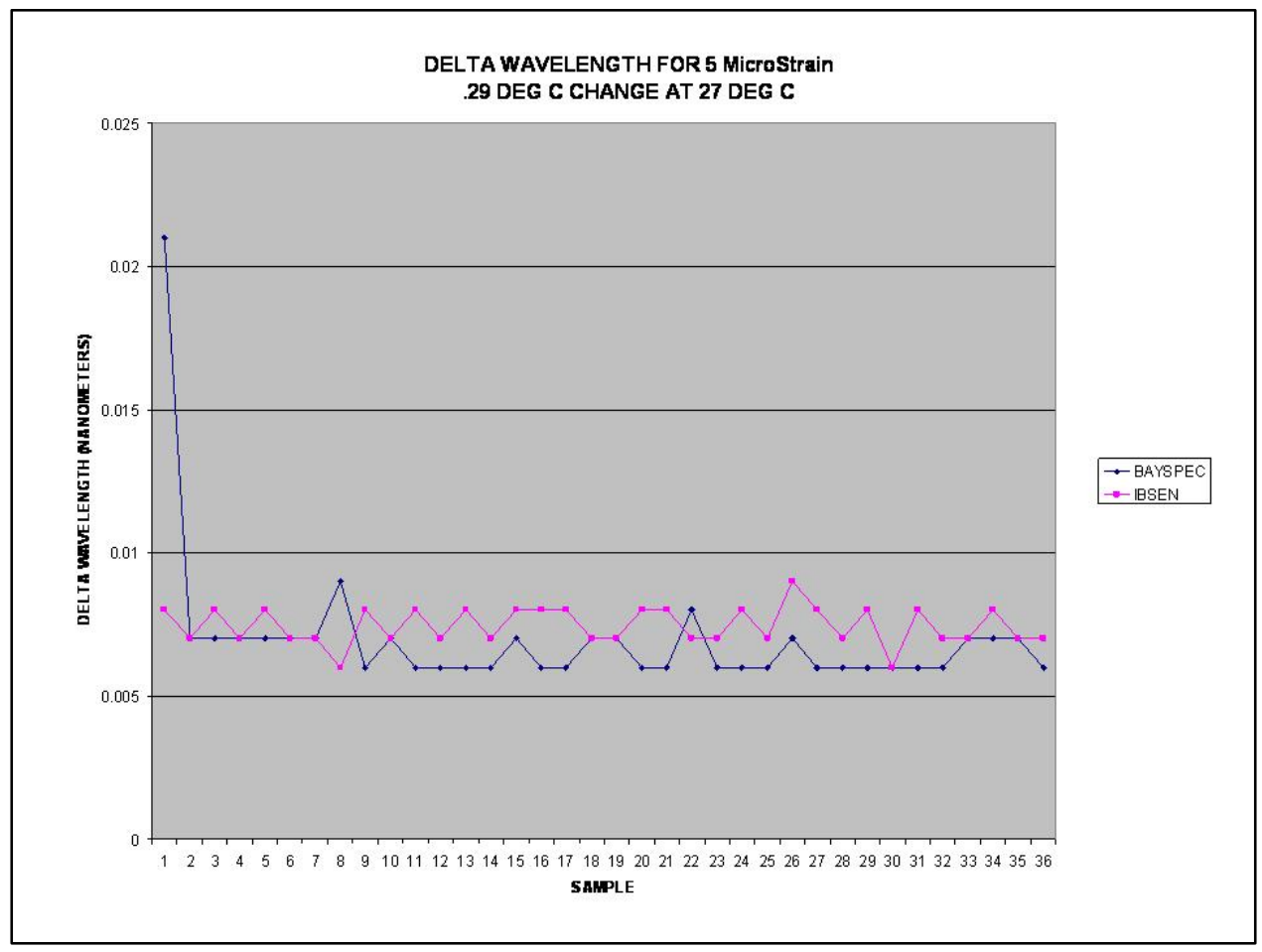

Figure 17. Fiber Bragg Grating Sensitivity to Temperature at $27^{\circ} \mathrm{C}$ 
Note that occasional excursions of data points occurred for the Bayspec unit beyond the normal data spread. This proved to be a recurring problem with the Bayspec. The USB Labview drivers provided by Bayspec were locked and the software could not be viewed to eliminate this problem. Bayspec has since informed the team that a new hardware unit with programmable USB drivers is now available. The current unit cannot be recommended for embedded applications due to this recurring problem. The Ibsen unit did not display this problem at all. The $\mathrm{CCD}$ and electronics for the Ibsen unit were from Hamamatsu, an old standard in this technology. The Bayspec unit is quoted as American made. The conclusion is that either unit could be used for 5 micron strain measurements with a reasonable error band, with the exception of occasional glitches by the Bayspec unit.

A stability test was run on the stainless Bragg housing. Significant creep was seen in the $3 \mathrm{M}$ epoxy at both ends of the tube. The mechanical creep experienced with epoxy mounting supports further glass solder or ceramic techniques for attaching the fiber Bragg gratings.

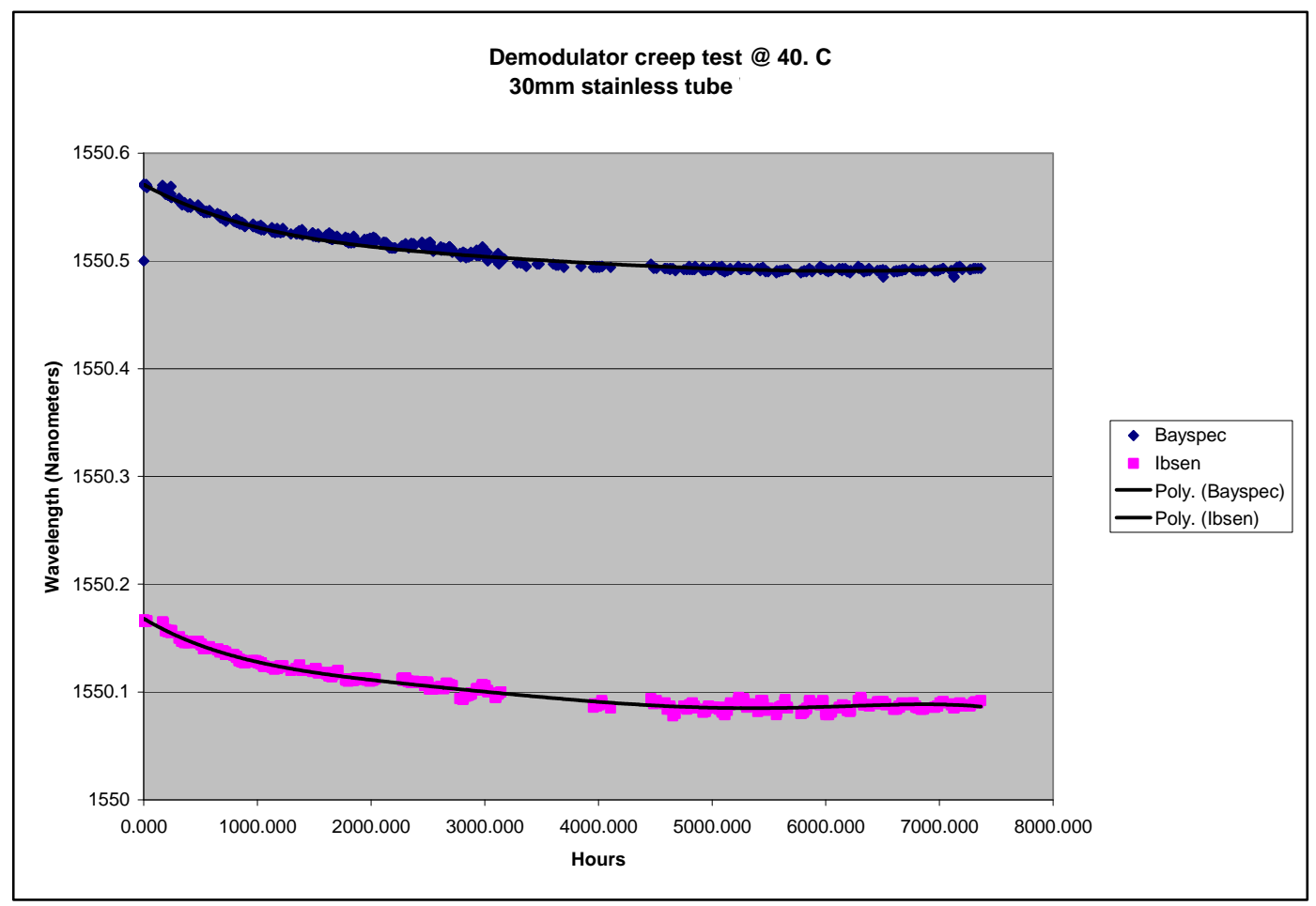

Figure 18. Fiber Bragg Housing Stability Test 


\section{Glass to Metal Seal Technology}

After determining that $3 \mathrm{M}$ suffered from creep during the thermal sensor test (Figure 18) a study was initiated to attach fiber Bragg gratings inside Kovar ferrules using a glass to metal seal. A sealed ferrule is shown in Figure 19.

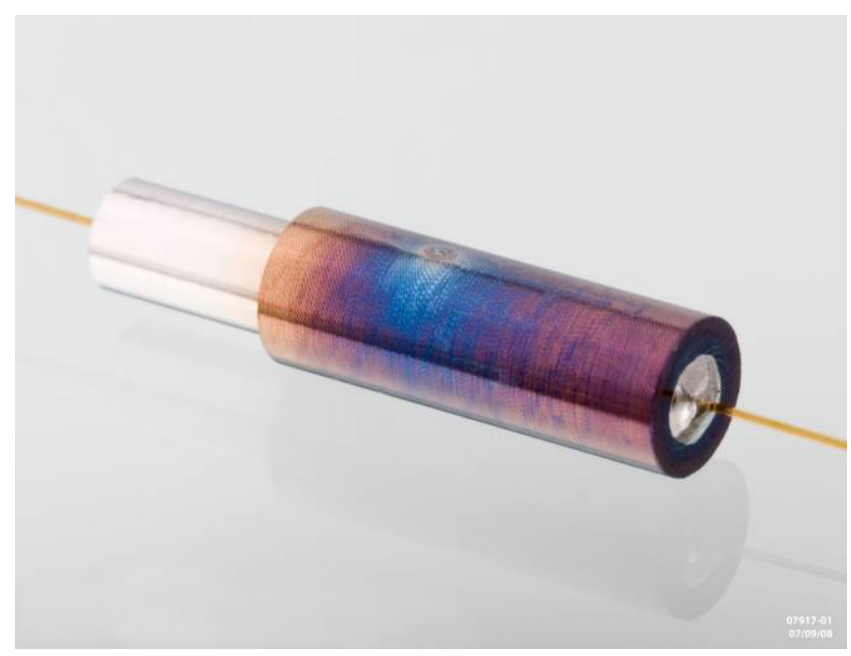

Figure 19. Stripped Single Mode Fiber Glass Sealed to Kovar Ferrule

The glass solder used was Diemat. The solder preform is a lead glass which melts at $375^{\circ} \mathrm{C}$. This temperature exceeded the safe level for heating lead, a known carcinogen, so special processing was required. Also, the fiber polyimide coating had to be window stripped prior to soldering. A plasma-based window stripper was acquired and used to strip a 1 millimeter window of the polyimide, allowing a direct solder to glass interface.

\section{Crack Initiation Measurement Using Fiber Bragg Gratings}

The technology of measuring strain with fiber optic Bragg gratings provides a sensor that is minimally intrusive, highly accurate, and totally optical with no electrical elements at the sensor. The penetration aperture required for a single sensor, or series array of sensors, is only 150-250 microns diameter with resolution available to the pico-strain.

Previous claims of ultrasonic measurements pointed to a possible crack initiation and propagation monitor. A crack initiation and propagation study was performed to confirm the viability of Bragg gratings for this application. A test was designed using precracked compact tension specimens with both Bragg grating and ultrasonic sensors to 'listen' for crack growth. 


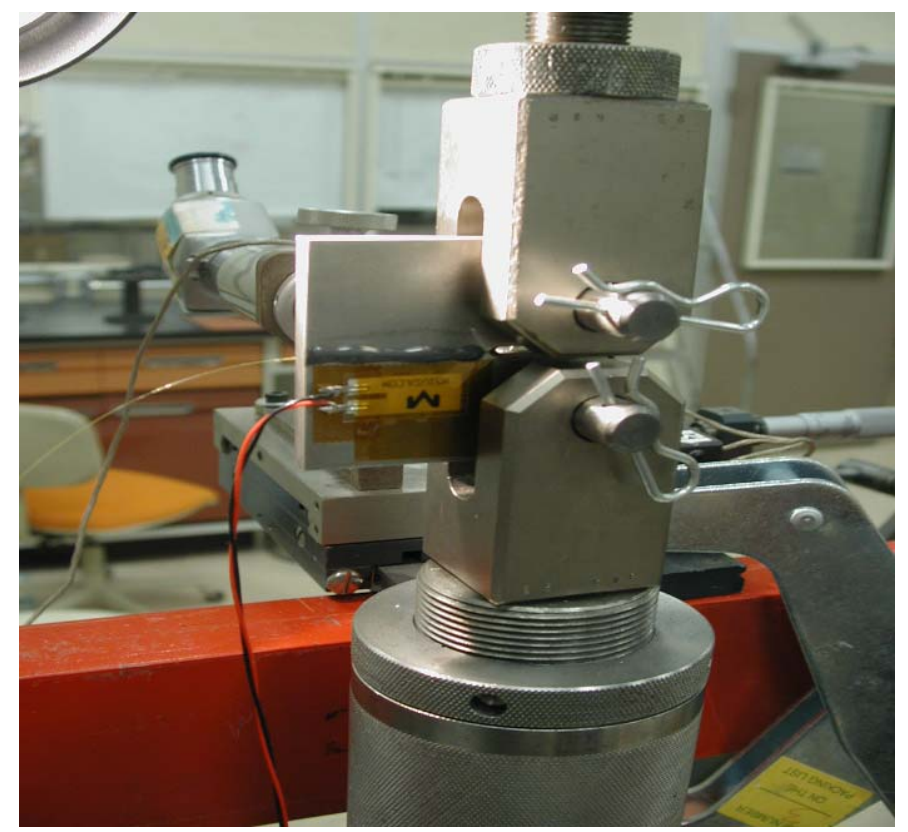

Figure 20. Compact Tension Specimen with a Bragg Grating and a Conventional Ultrasonic Sensor

The pre-cracked specimens were fatigue cycled in a universal test machine that enabled precision crack growth over several hours.

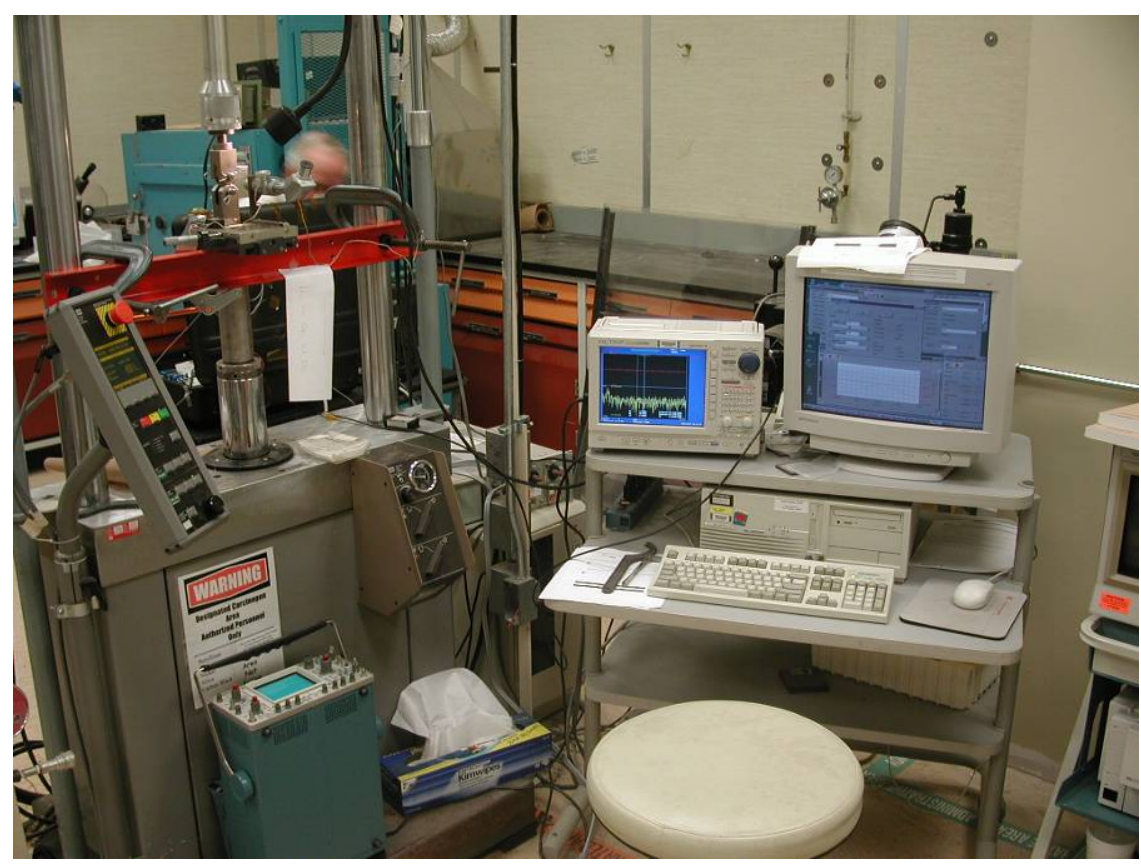

Figure 21. Precision Crack Growth Monitoring Using a MTS Universal Test Machine in Cyclic Fatigue 
The optical system employed to derive the ultrasonic signal from the Bragg grating was a fiber optic laser, shown in Figure 22. The frequency of the laser was determined by the Bragg grating strain. As the crack growth extended, an ultrasonic signal vibrates the Bragg grating, which in turn produces a frequency change in the fiber laser.

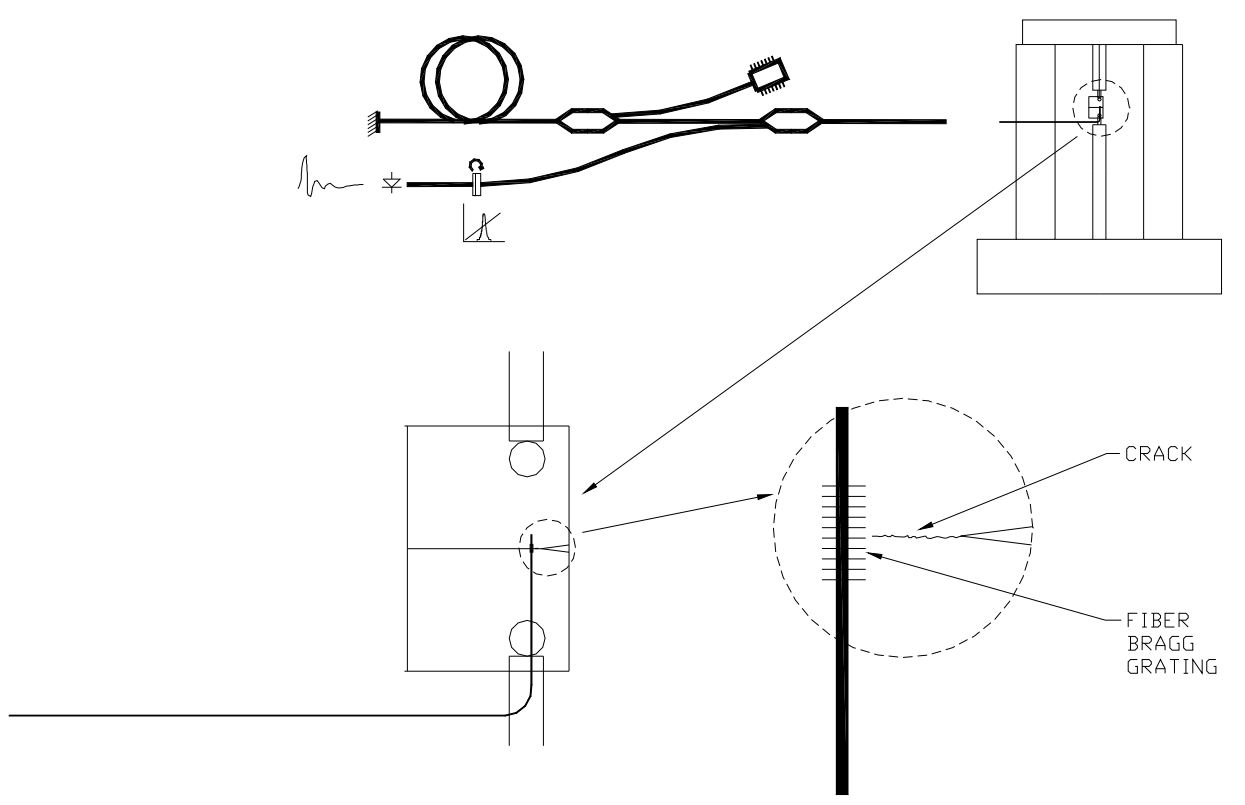

Figure 22. Fiber Laser Bragg Grating Demodulator Ultrasonic Sensor

In the fiber laser diagram, an edge filter is used to change the vibrating laser frequency output created by the ultrasonic signal from the crack to an intensity output. A high speed InGaAs photodetector then outputs to a digital storage oscilloscope. A photo of the fiber laser is shown in Figure 23.

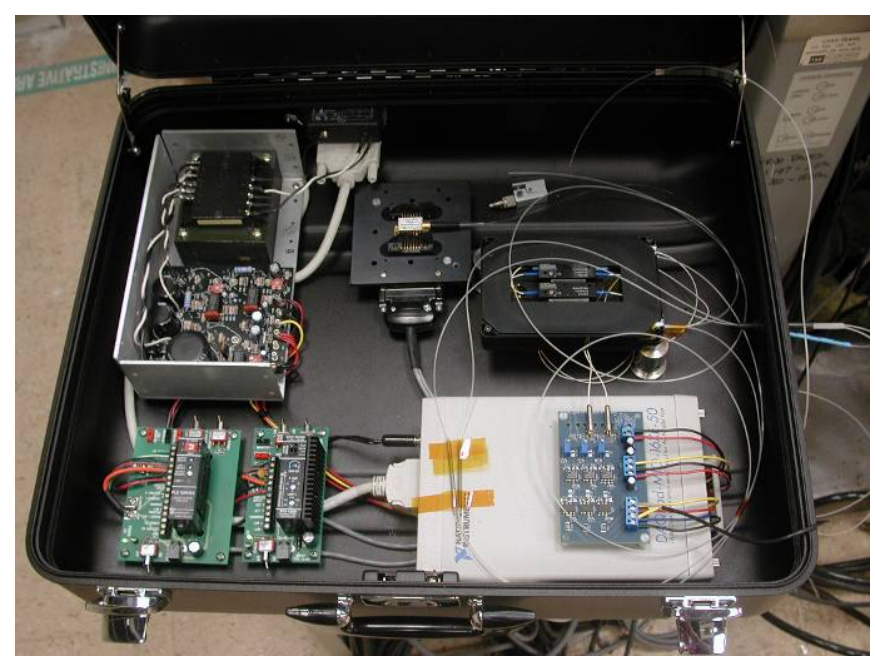

Figure 23. Fiber Laser Ultrasonic Detector System 
The intent of this study was not to build yet another ultra-high speed Bragg demodulator, but to evaluate whether HE could be monitored for cracks using embedded Bragg gratings. Since the fiber optic containing the Bragg grating is only 125 in microns diameter and the grating itself can be as small as a few millimeters in length, the placement of gratings in molded HE could have little effect on the explosive wavefront. Several factors determine the practicality of this measurement: Can the Bragg see crack initiation and growth? Will crack growth in HE produce an ultrasonic signal? For one thing, the crack initiation growth event is dynamic. A crack monitoring system either has to be listening at all times for a dynamic event, or the crack must produce a permanent change in the sensor. This investigation only considers the dynamic 'listening' mode. A more fragile sensor than fiber optic might be required to monitor statically after the crack had occurred. A fracture of the grating would produce a permanent change in the reflected output.

A crack growth event is shown in Figure 24 from an ultrasonic transducer and in Figure 25 from the fiber laser. Both of these signals occurred on the same crack growth event. The compact tension specimen used was fabricated from Kovar. The Bragg grating was bonded to the Kovar sample with the grating under tension. Multiple tests with multiple specimens were obtained to verify that actual crack growth had been detected.

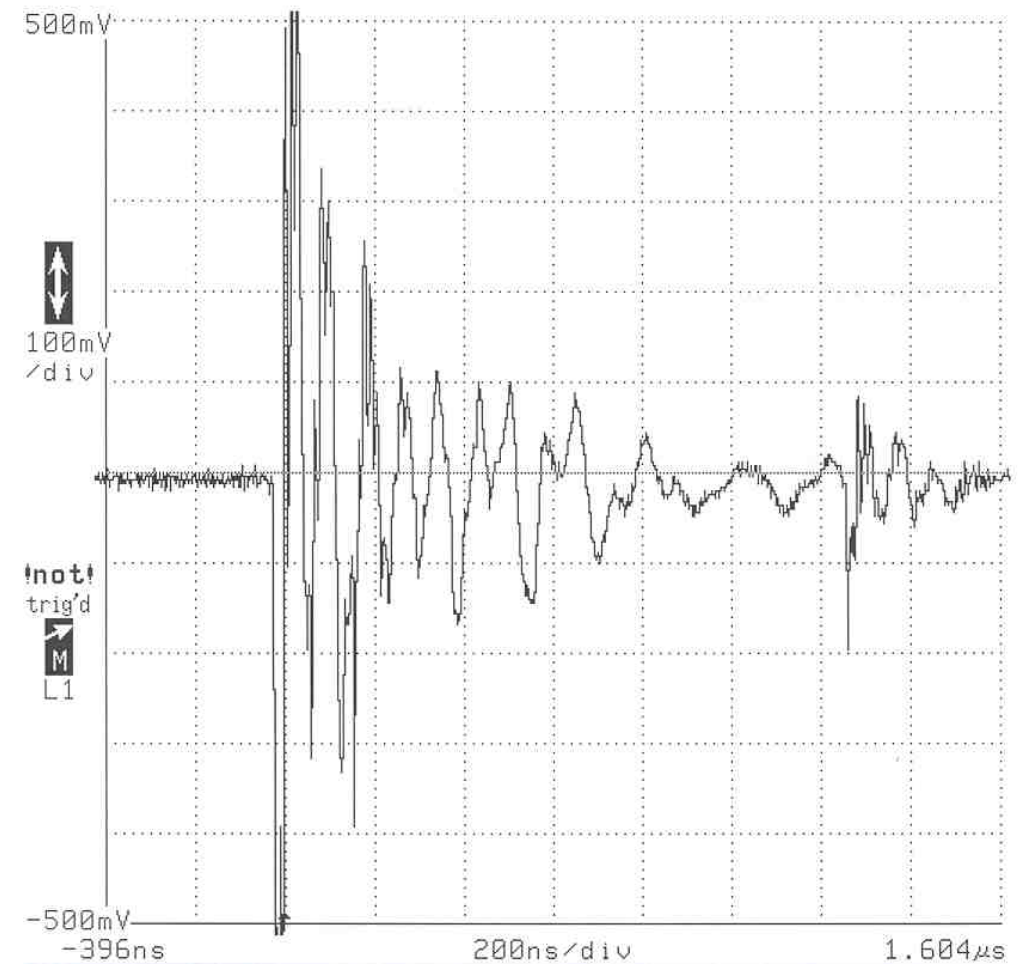

Figure 24. Ultrasonic Signal From Crack Growth in Kovar Compact Tension Specimen 


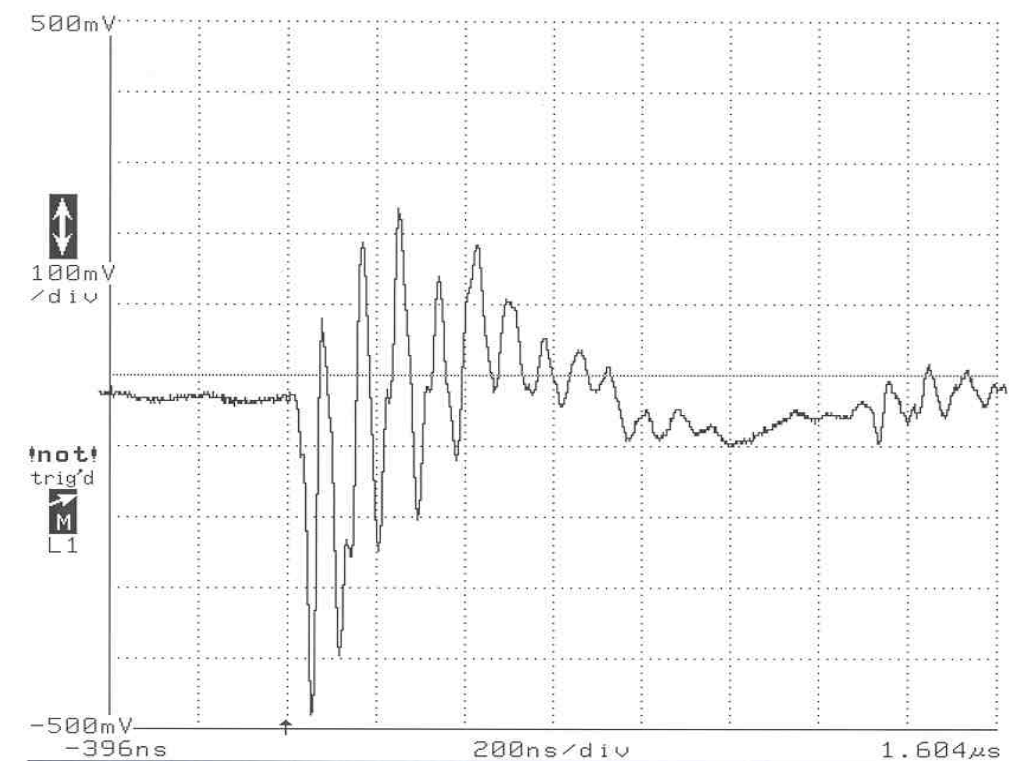

Figure 25. Signal From Bragg Fiber Laser in Kovar Compact Tension Specimen

Kovar is obviously not a good surrogate for HE material. Several Delrin compact tension specimens were fabricated to more closely simulate HM. The Bragg laser signal, obtained from an instantaneous crack to total failure is shown in Figure 26. Even with the tightest control of the universal test machine, the team was unable to control crack growth in this material.

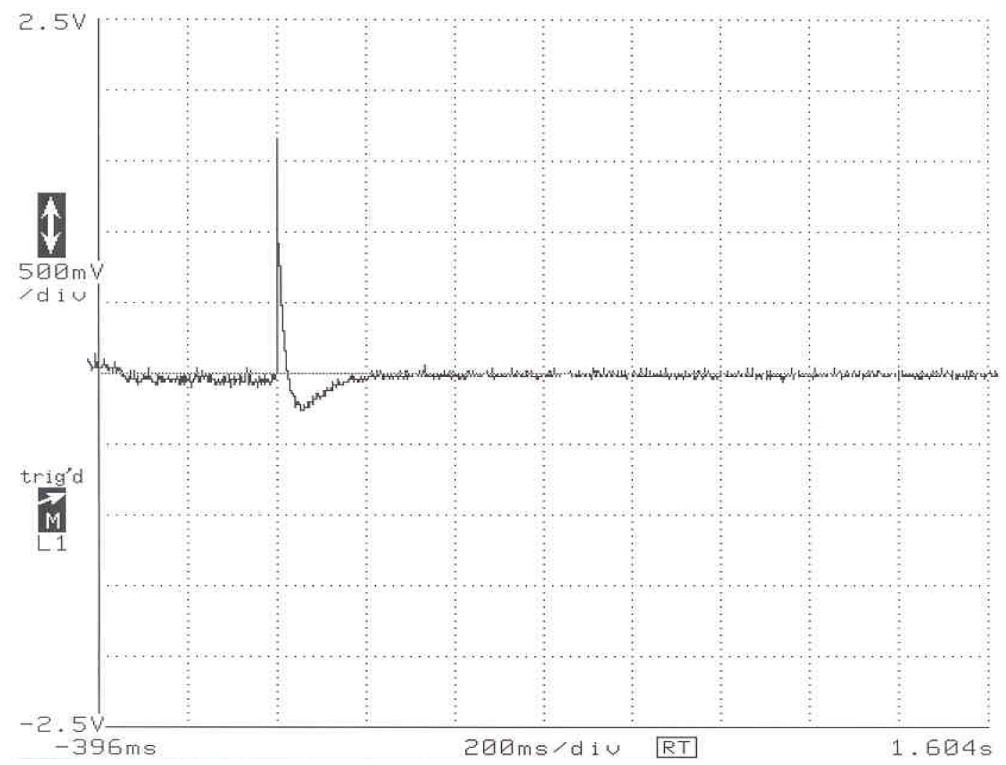

Figure 26. Bragg Grating Signal From Delrin Compact Tension Specimen 
Several conclusions can be drawn from the extensive mechanical testing from these gratings:

- Bragg gratings can detect crack growth, but their ultrasonic signature is often different from the ultrasonic sensor;

- Crack growth signals are instantaneous and quickly dampen out; and

- Gratings parallel to the crack responded better than gratings perpendicular to the crack.

The ultrasonic sensor output has a higher frequency substance than the Bragg grating output. This may be due to roll off of the frequency response of the detector used in the fiber laser. The Indium Gallium Arsenide (InGaAs) detector that was used had a $150 \mathrm{MHz}$ response. The ability to detect crack growth did not seem to be hindered by this lower frequency response. It was noted that it was significantly easier to trigger off of the ultrasonic signal than the Bragg grating signal. This was attributed to the reduced gain in the parametric amplifier chain of the InGaAs photodetector.

The Bragg grating signal in the Delrin sample (Figure 26) was obtained as the sample initiated a crack and propagated to failure. As noted, the team found it difficult to grow a crack in Delrin due to its low $\mathrm{K}_{1 \mathrm{C}}$ (the critical stress intensity factor or simply the fracture toughness). The longer time base in Figure 26 was chosen to aid in capturing the data.

The data indicates that Bragg gratings can be used to monitor for crack growth in low and medium $\mathrm{K}_{1 \mathrm{C}}$ such as HE. However, no significant improvement in capturing the crack growth signal was noted in the Bragg grating response relative to the standard ultrasonic sensor response. The all optical nature of the Bragg grating system is a plus from the embedded sensor concept. Also, an actual fracture of the Bragg grating, or its feed fiber optic, would create a signal change that could be monitored for crack location. This would be the case for a series chain of Bragg gratings on a single fiber. 


\section{Fiber Processing}

A capability was established to fuse single mode and multimode, up to 250 micron diameter, optical fiber. The fiber fusion splicer is shown in Figure 27.

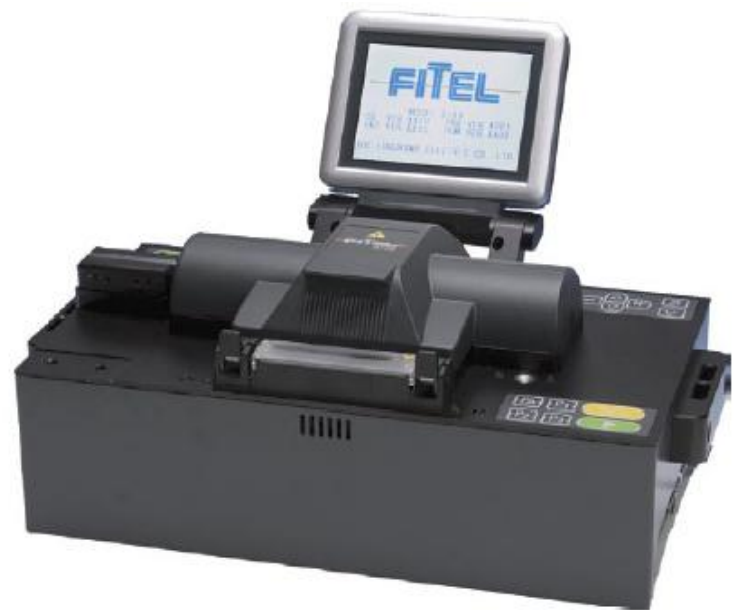

Figure 27. Fitel Fusion Splicer

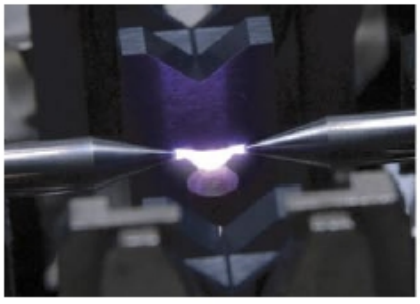

ADVANCED FUSION CONTROL

Arc curving, arr cermencing and arc scanning functions on th allowit to performa wide variety of advanced fusion controltechiques tensile strength for any specialty fiber combinatensile strength for any specialty fiber combina-

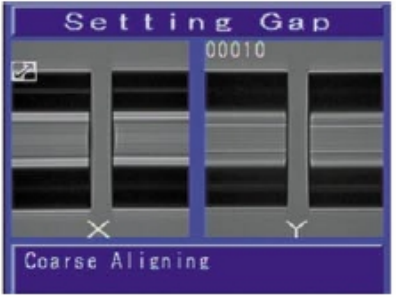

FAST SPLICE TIME!!

The splice time is lightning fast at 42 seconds for DANMA and 20 seconds for the fastest in the allowing allowing you to increase efficiency on

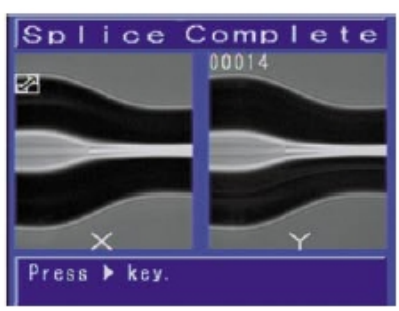

SPECIALTY SPLICING MADE EASY

The advanced features of the allow you to types. Whether performing high-strength splices, splicing small cladding fibers $(80 \mathrm{~mm})$, large

cladding fibers $(400 \mathrm{~mm})$, high MFD splicing cladding fibers ( $400 \mathrm{~mm})$, high MFD splicing
combinations, PM fibers, or erbium-doped fiber, the is the splicer for your high-end applications.

Figure 28. Splicer Capabilities 
The Fitel splicer is capable of automated fusing of polarization fiber, different size fibers, and selective fiber attenuation. To complement this capability, a fiber recoater and tensile tester was acquired to allow recoating the acrylate buffer after the fusion process. The recoater is shown in Figure 29.

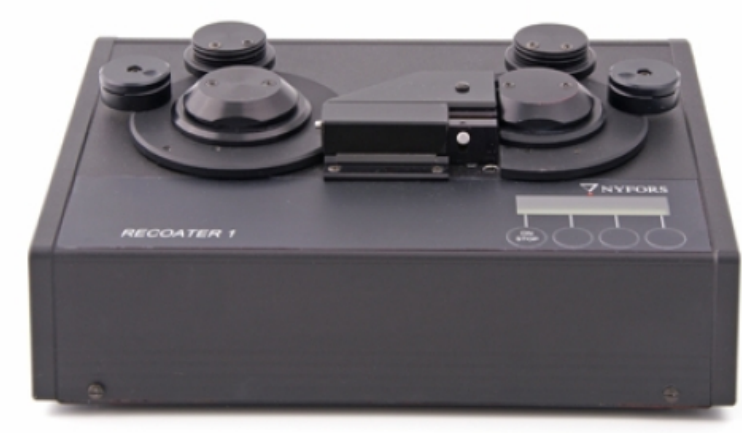

Figure 29. Fiber Recoater

Both the fusion splicer and the fiber recoater provide the capability to custom design linear multiple fiber arrays. An example would be a single fiber with five gratings or more in series that could be molded into a material to check for cracks or localized strain. The demodulated signal from a series of five gratings is shown in Figure 30. Each fiber Bragg grating in the single fiber reflects a different wavelength. Each wavelength measurement determines the strain at that particular grating in the fiber length.

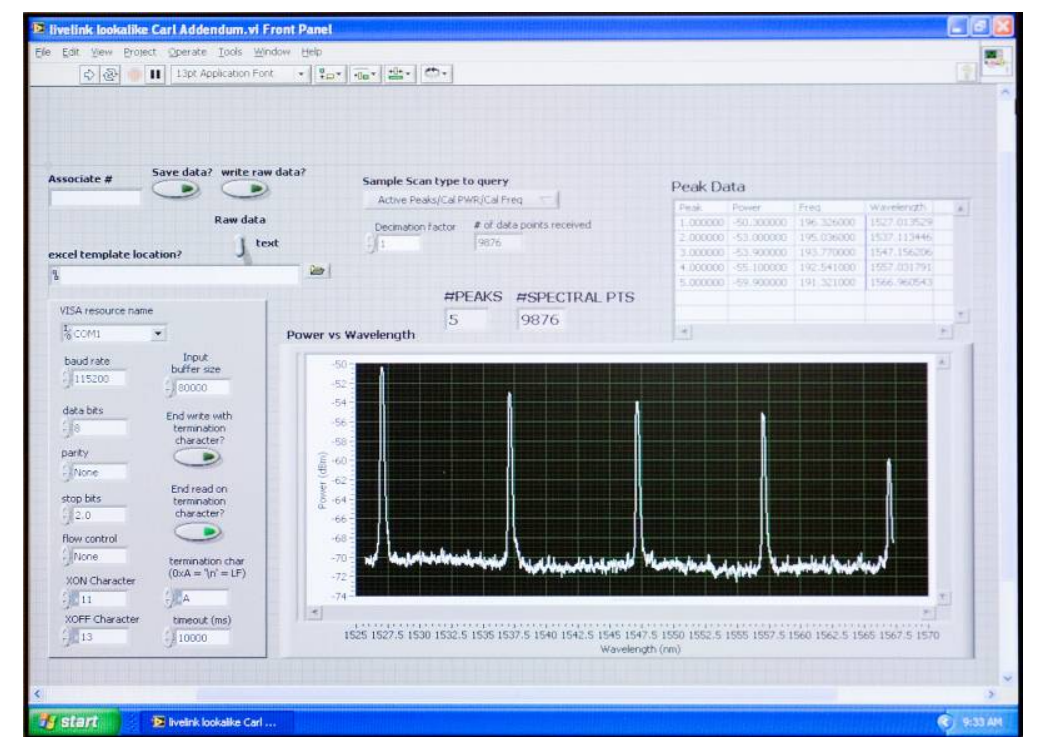

Figure 30. Demodulated Wavelength Display of Five Gratings in Series in a Single Mode Fiber 


\section{Evaluation of the Luna OBR as a Strain Measuring Device}

The Luna Technologies "Optical Backscatter Reflectometer" (OBR) is marketed with software that the manufacturer claims is capable of measuring strain in a single mode fiber, in the team's case, up to 32 meters in length. They claim 1 microstrain resolution in these measurements. Several critical tests were designed to investigate these claims. The application would be a rollup test system that would plug into a single fiber in a storage assembly. The fiber could be embedded into HE or other material whose integrity, from the date of manufacture, was a critical issue. Dislocations due to cracks, material displacement, and unexpected strains would all be monitored in the path length of this single fiber.

The strain measuring software provided by Luna is sensitive to strain variations due to temperature as it is to other mechanical causes. This is not necessarily a limitation since temperature generating components also could be monitored by the same fiber.

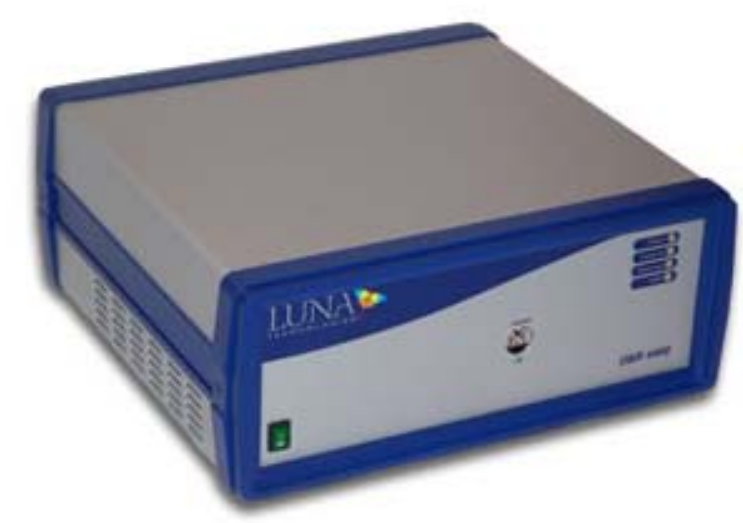

Figure 31. Optical Backscattering Reflectometer (OBR)

The following tests were conducted:

1) Mechanical tensile strain over a half-inch gauge length

2) Mechanical tensile strain over a one-inch gauge length

3) Mechanical tensile strain over a three-inch gauge length

4) A thermally strained array of varying gauge lengths with loose fiber in between strain elements

5) Resolve a five Bragg grating array with the OBR

6) Compare fiber Bragg versus OBR strain measurement

In these tests, no attempt was made to determine the absolute accuracy of the observed strain measurement. However, the final test compares the mechanical strain measured by a Luna Technologies OBR to a Micron Optics 1 fiber Bragg grating demodulator. The application for this instrument would be a global mapping of the integrity of the system. Critical strain measurements would be more easily obtained by implanting fiber Bragg gratings where required, 
one for strain and one for temperature compensation. Also, test results showed that really low values of strain, such as 0 to 10 microstrains, have significant noise which makes measurements at this level rather meaningless. This result prevented the 1 microstrain resolution from being evaluated for mechanical strain. This claim by the vendor is probably related to the readout resolution, rather than the true measurement capability. The fact that this machine can measure strain in a random fiber length and show its location is a remarkable feat in itself.

\section{Test 1}

Figure 32 shows the strain distribution measured by the OBR for a half-inch gauge length of fiber. The fiber was stressed by clamping at two locations separated by one half inch and pulling the fiber by a micrometer driven stage.

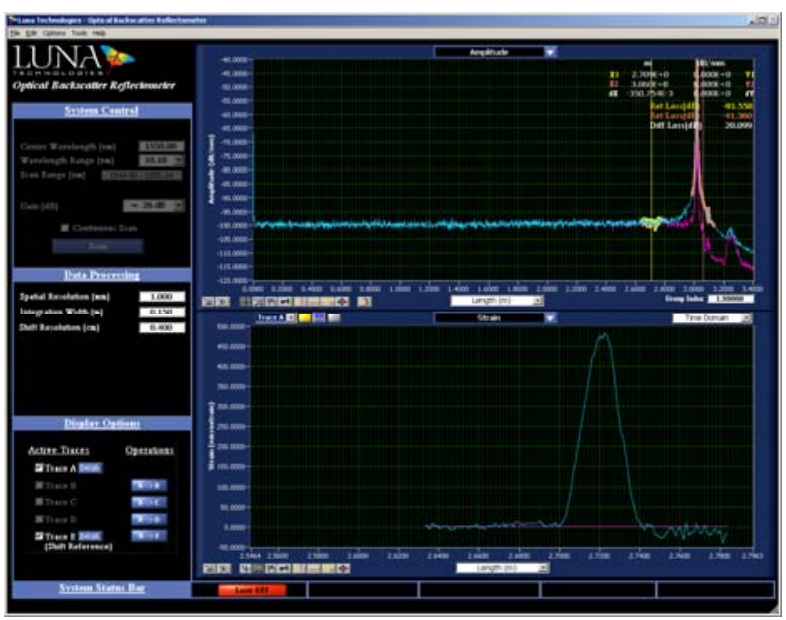

Figure 32. Lower Graph: $1 / 2$-inch Gauge Tensile Test of Single Mode Fiber. $~ 475$ microstrains 


\section{Test 2}

Figure 33 shows the strain distribution measured by the OBR for a one-inch gauge length of fiber. The fiber was stressed by clamping at two locations separated by one inch and pulling the fiber by a micrometer driven stage.

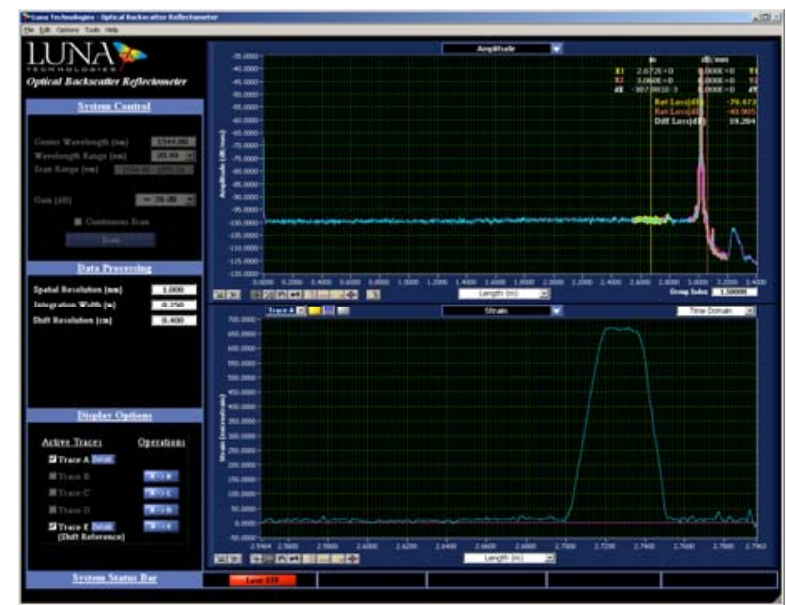

Figure 33. Lower Graph: One inch Gauge Tensile Test of Single Mode Fiber. $\sim 660$ microstrains

\section{Test 3}

Figure 34 shows the strain distribution measured by the OBR for a three-inch gauge length of fiber. The fiber was stressed by clamping at two locations separated by three inches and pulling the fiber by a micrometer driven stage.

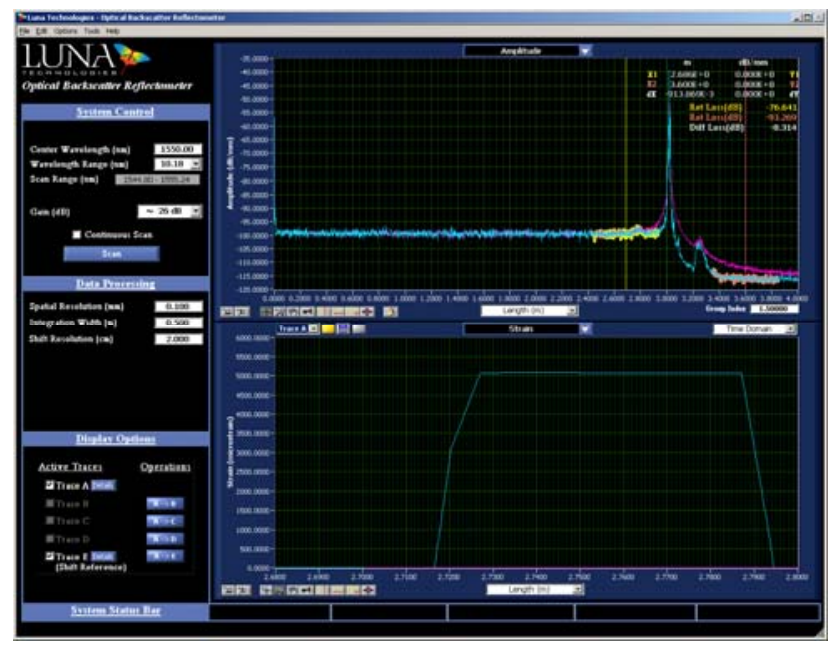

Figure 34. Lower Graph: Three-Inch Gauge Tensile Test of Single Mode Fiber. 5,000 microstrains 
Additional tests for three-inch gauge lengths at strains at 30, 35, 90, 140, 220, 425, 1100, 1450, $1700,2000,2400,2750,2900,4100$, and 5000 microstrain were run.

Some of the noise in the data, referred to earlier for low strain levels, is apparent in the 30 microstrain graph, Figure 35.

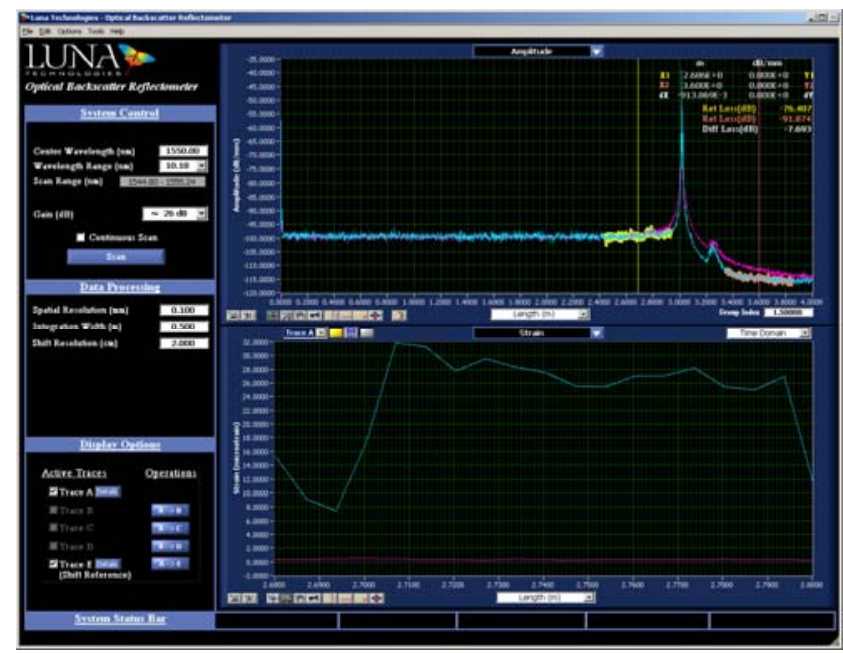

Figure 35. Lower Graph: Three Inch Gauge Tensile Test of Single Mode Fiber. $\sim \mathbf{3 0}$ microstrains

\section{Test 4}

Figure 36 shows the strain pattern obtained from a fiber array of multiple gauge lengths with loose fiber lengths in between. The gauge lengths in inches and loose fiber separation lengths from right to left in the lower graph of Figure 36 were:

GAGE LENGTH SPACING

\begin{tabular}{|c|c|}
\hline $6 / 32$ & $11 / 32$ \\
\hline & $11 / 32$ \\
\hline $8 / 32$ & \\
\hline $12 / 32$ & $15 / 32$ \\
\hline & \\
\hline $19 / 32$ & $30 / 32$ \\
\hline & \\
\hline 1 & $30 / 32$ \\
\hline & \\
\hline 2.25 & \\
\hline &
\end{tabular}

Table 2. Gauge Length and Loose Fiber Spacing of Figure 36 
The surprising result seen in Figure 36 does not clearly show the zero strain regions of the loose fiber separations. Tests run at $50,60,70$, and $80^{\circ} \mathrm{C}$ yielded basically the same results. Each strained fiber section consisted of a length of fiber bonded at two points onto a stainless steel machining ruler. The sections were stressed by placing the entire assembly into an oven. Each individual ruler, and its corresponding strained fiber section, was separated by loose unstrained fiber. The gauge lengths for the strained fiber sections were shorter, and in some cases longer, than the minimum resolvable length quoted by the manufacturer.

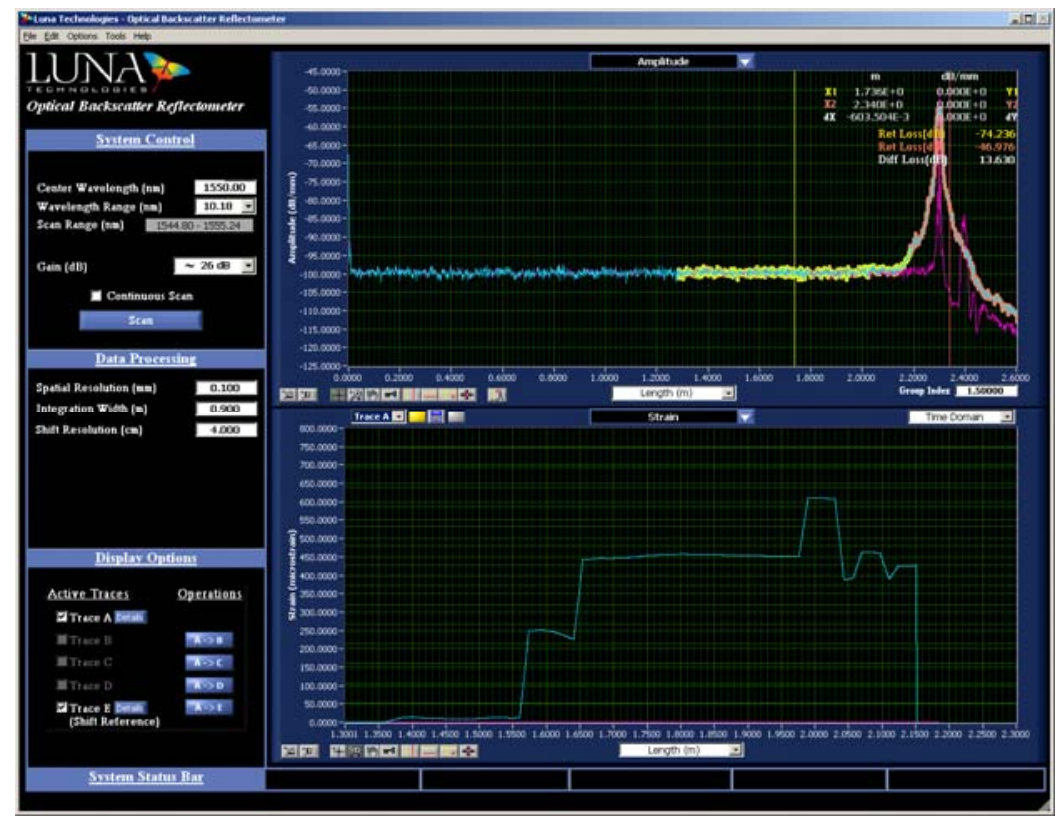

Figure 36. Lower Graph: Multiple Gauge Length Strained Fiber Sections on a Single Fiber

\section{Test 5}

This test demonstrates that the OBR is capable of measuring the wavelength of five gratings in series on a single fiber. The OBR can only calculate one grating wavelength at a time to do the measurement technique employed by the software. The operator has to position a vertical cross hair over the reflected signal in the top half of the graph to display the wavelength on the bottom half of the graph. Although it is demonstrated that Bragg gratings can be demodulated with this equipment, the micron optic approach is considerably simpler to use and has much higher accuracy. 


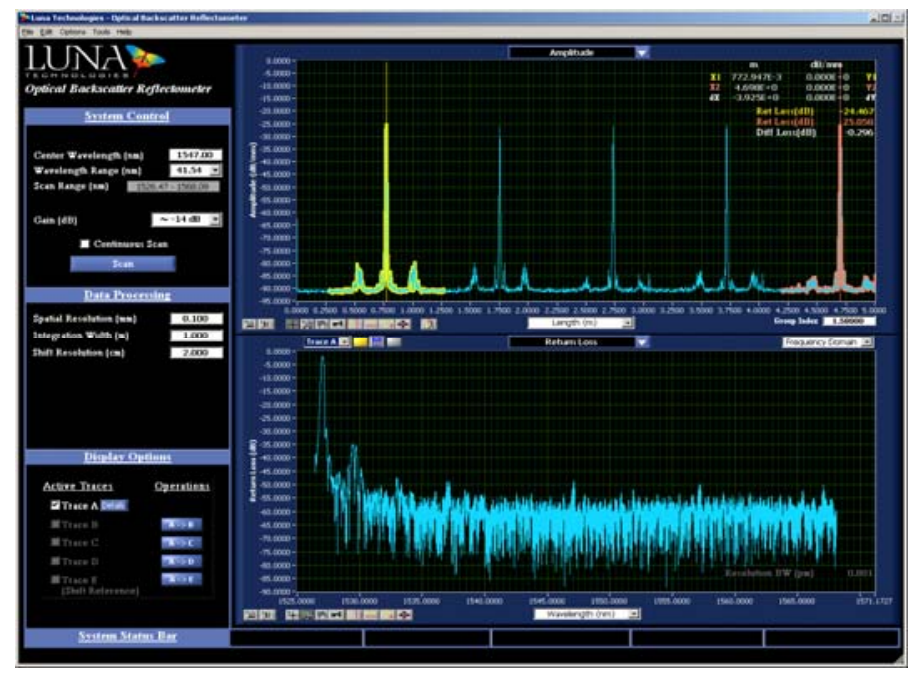

Figure 37. Demodulation of 1527 Nanometer Bragg Grating

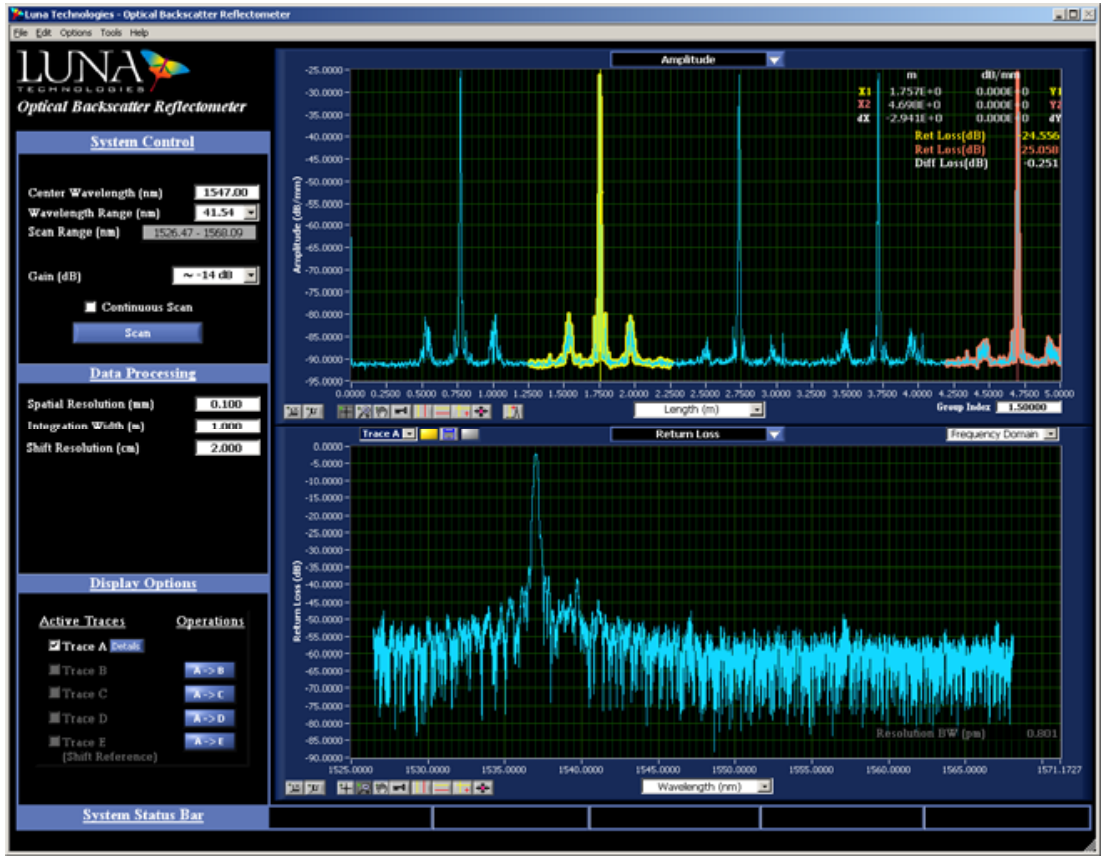

Figure 38. Demodulation of 1537 Nanometer Bragg Grating 


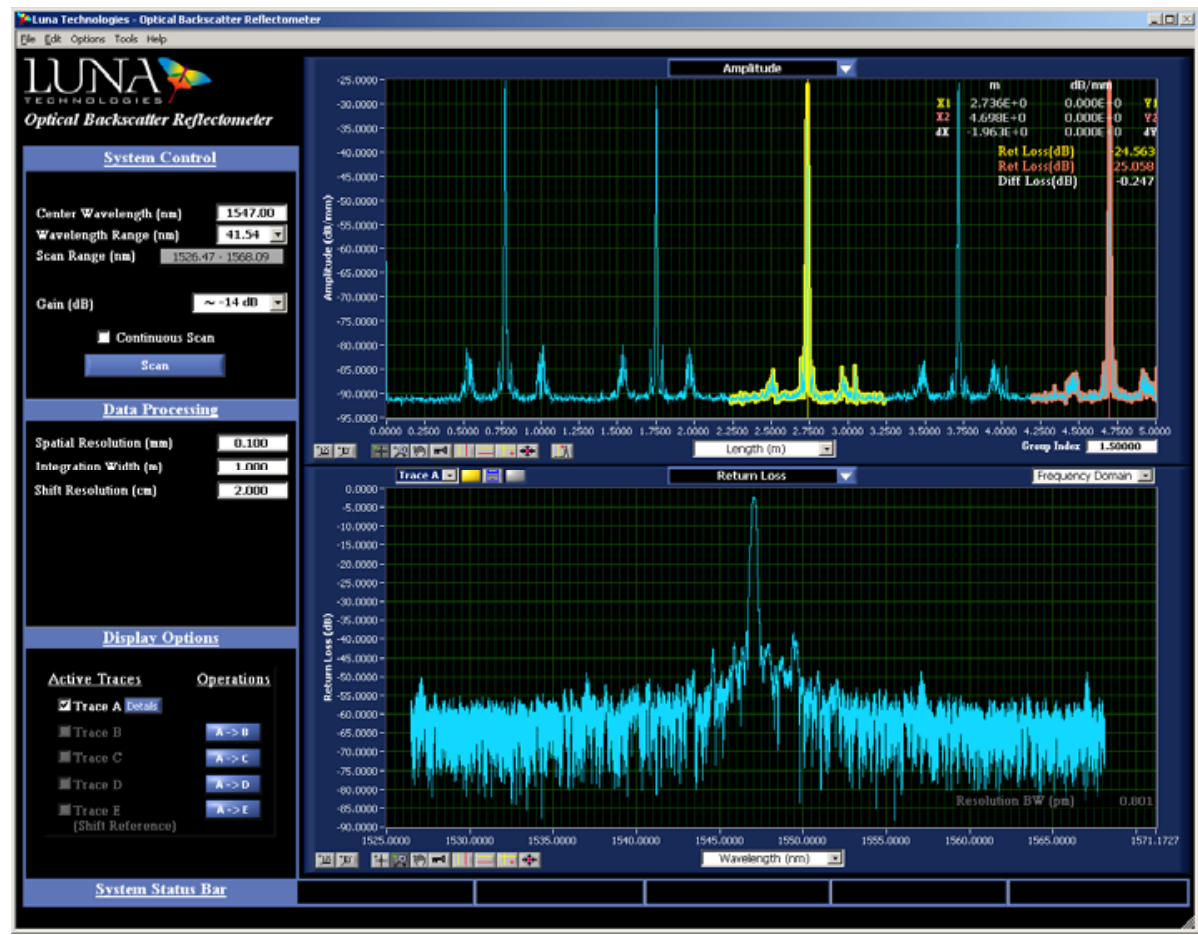

Figure 39. Demodulation of 1547 Nanometer Bragg Grating

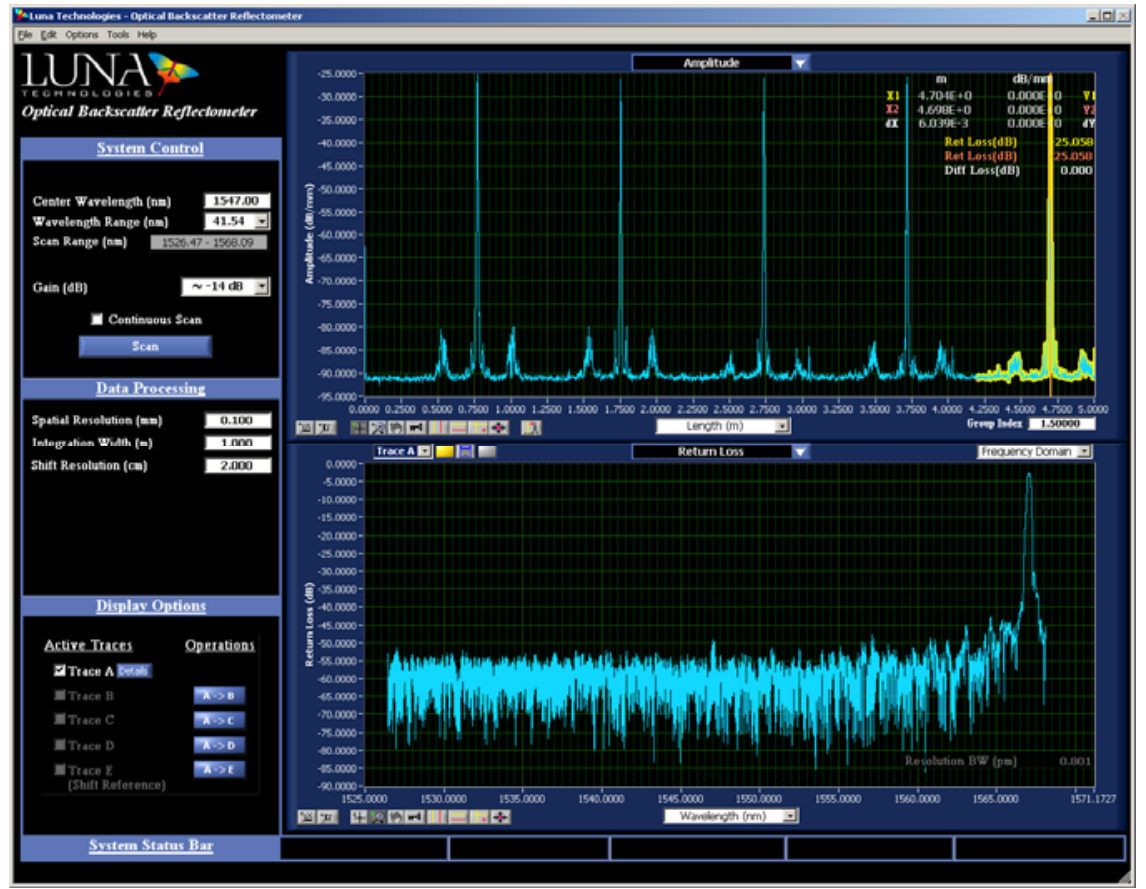

Figure 40. Demodulation of 1557 Nanometer Bragg Grating 


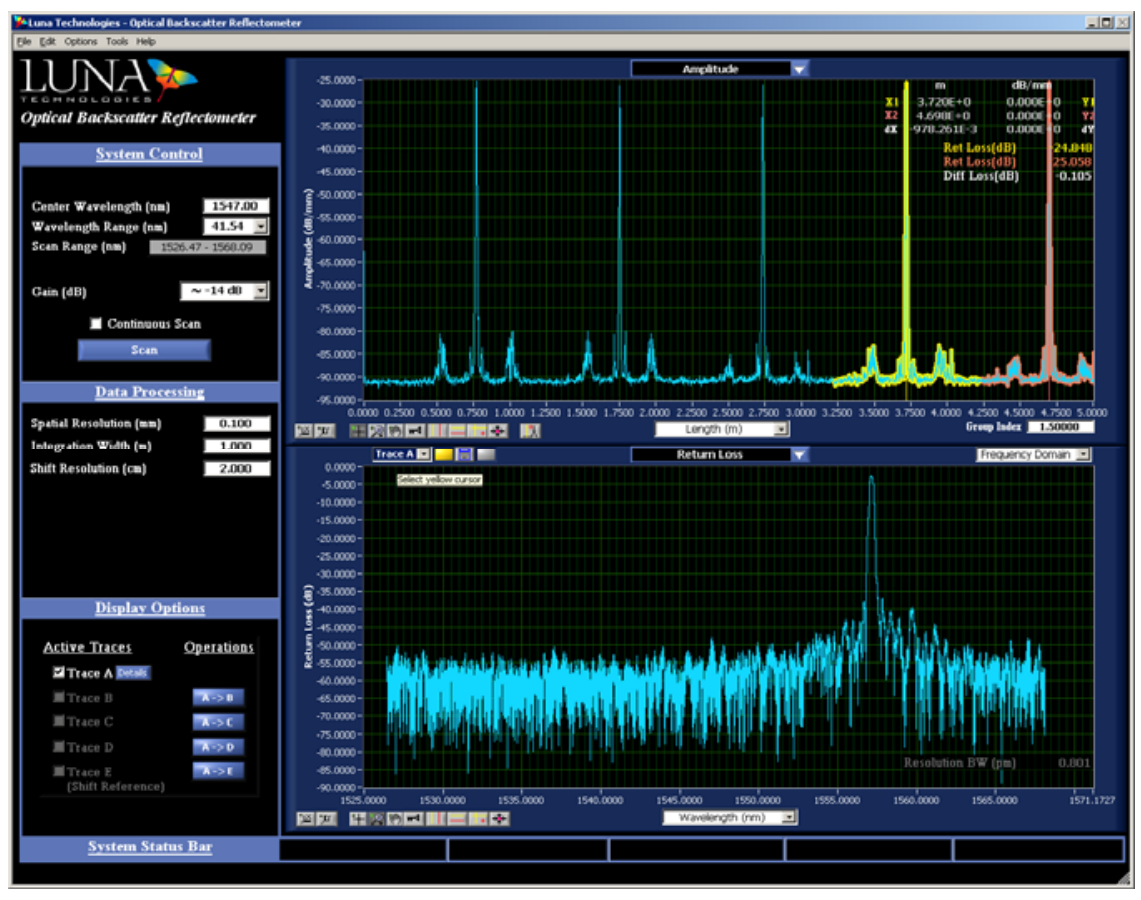

Figure 41. Demodulation of 1567 Nanometer Bragg Grating

The final test was probably the most critical for the intended application of the OBR. The unit would be required to take a measurement in the field, record the measurement, disconnect, and return at a later date. At a later time, the original reflected signal from the fiber would be reloaded off of the computer hard drive and a new measurement taken to find stress concentrations and broken fiber ends. The test is described as follows:

Set up single mode fiber into a mechanical strain fixture with a 3-inch gauge length. The fixturing was set near the end of a ten foot length. No gratings were employed in these measurements, just plain single mode fiber. A reference signal was captured and saved at zero strain. The fiber was pulled to 2000 microstrain as read on the OBR and held there. At this point the fiber was detached from the OBR. The OBR was then turned off.

Next the OBR was turned back on. A new calibration run was performed on the OBR. The zerostrain reference signal was loaded off of the hard drive. The test fiber was reattached to the OBR and a new scan of the 2000 microstrain level fiber was performed. The strain software of the OBR was exercised. The result was a duplicate of the original 2000 microstrain curve measured the first time. The tests determined that it is possible to record a reference low strain signal from a single mode fiber, remove the equipment, come back at a later time or date, recalibrate the OBR, and measure new strain levels existing on the original fiber. 


\section{Test 6}

The final test compares the strain measured on two independent fibers, one on the Micron Optics 1 with a Bragg grating and the other a single mode fiber, without gratings, in the LUNA OBR. Both fibers were placed in the same clamps and the strain was applied with micrometer staging. The results are shown in Figure 42.

Fiber Bragg VS OBR Strain

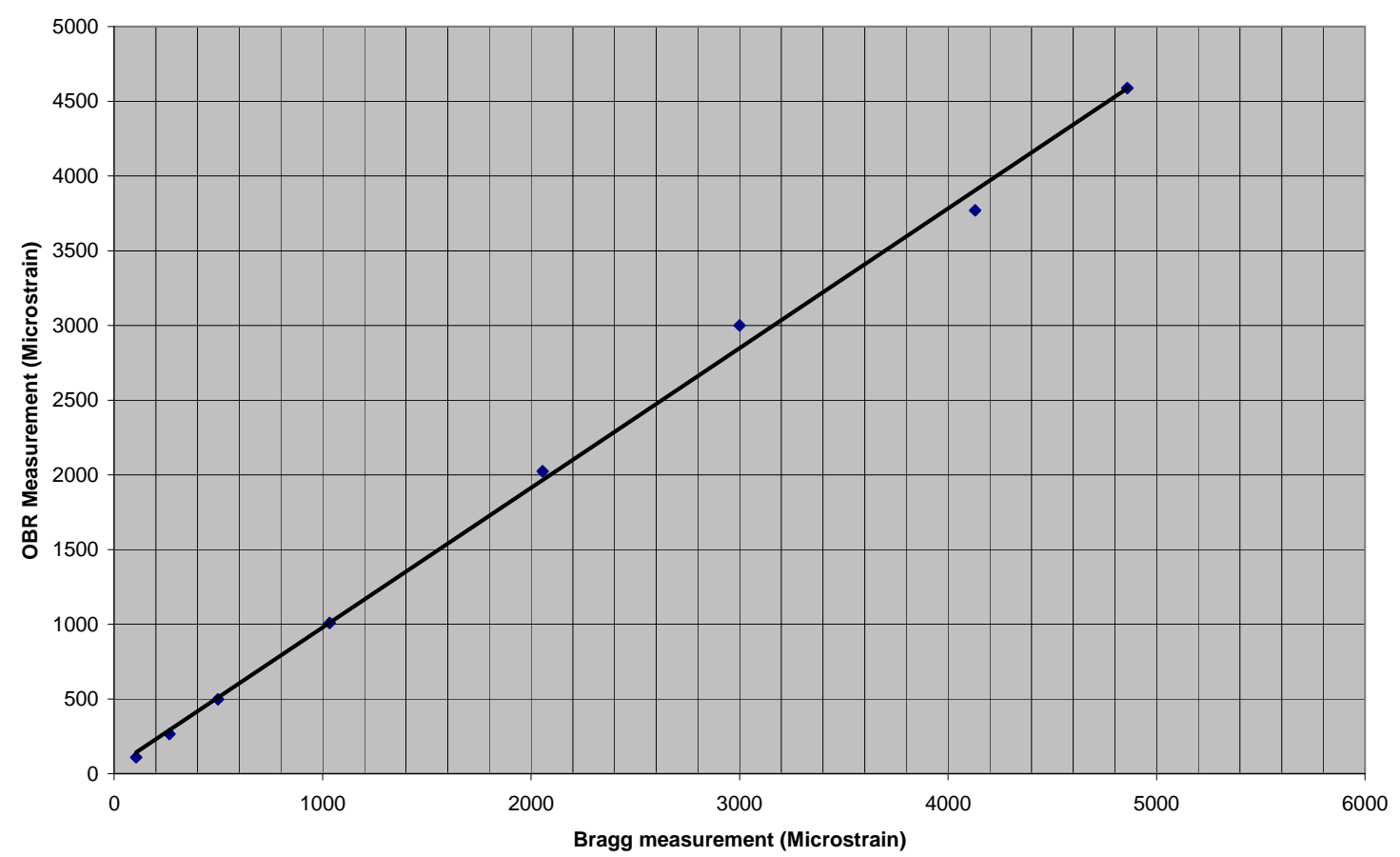

Figure 42. OBR Measured Strain Versus Fiber Bragg Grating Readings

Although the data shows discrepancies at the higher strains, these results are acceptable considering the added versatility of the OBR to detect broken fiber and extended strain measurements. At very low strain levels, zero to about 10 microstrains, the noise was significant enough to make judgment calls on the strain levels and gauge lengths difficult. The question whether this instrument is capable of resolving $+/-1$ microstrain, as stated by the manufacturer, was not resolved by this test. However, if it is possible it would most likely occur at elevated strain levels. The adjustments at low strain levels seemed critical and the graphed strain data, at these levels, was entirely inconsistent. At the higher strain levels, the $1 / 2,1$, and 3 -inch gauge length results were reasonable. An attempt to measure an array of strained fiber sections in plain single mode fiber was difficult because the unstrained connecting regions were not readily identifiable. Each grating of the five Bragg grating array was measured independently. Although there are other cheaper instruments that can perform the Bragg demodulation, the ability to observe the spectrum of the fiber grating in such detail would be very useful in grating manufacturing. The instrument provided consistent results even after a total shutdown and recalibration of the OBR. This last feature makes this an invaluable addition to field tests to check the mechanical integrity of a complex assembly in storage. The ability to find and measure 
a strain event in a length of single mode fiber was dependent upon the settings and the level of strain. Improper settings or very low strain levels could make target signatures hard to locate. Operator experience will be very important in using this piece of equipment.

\section{Gas Sensors}

Gas analysis is currently performed at the end of a product life in the stockpile. These analyses are used to try to model aging mechanisms but are based on one snap-shot at the end of life. Better aging models can be developed with real-time aging data and better predictions can be made on the life expectancy of components that age and when they need to be replaced. This project is supporting LANL and LLNL in determining aging characteristics of materials in the stockpile. Real-time identification of outgassing materials and their concentrations will allow for an improved fundamental understanding of the current aging mechanisms. Testing and analysis techniques are being developed to measure gases and their concentrations inside sealed weapon systems.

\section{Tunable Diode Laser Absorption Spectroscopy}

TDLAS is a technique for measuring the concentration of gases in a gaseous mixture. An advantage of TDLAS over other concentration measurement techniques is its ability to achieve very low detection limits. TDLAS can be used in applications for combustion process monitoring, trace species monitoring, leak detection, emissions monitoring and process control. Among the chemical species that can be detected by TDLAS instruments include: $\mathrm{CO}, \mathrm{NO}, \mathrm{CO}_{2}$, $\mathrm{NO}_{2}, \mathrm{CH}_{4}, \mathrm{NH}_{3}, \mathrm{O}_{2}, \mathrm{H}_{2} \mathrm{O}, \mathrm{HCL}, \mathrm{HF}, \mathrm{HBr}$ and $\mathrm{C}_{6} \mathrm{H}_{6}$. Typical detection limits for TDLAS range from 0.3 to 80 parts per million (ppm) when utilizing a 1 meter long gas cell. Typical detection limits, from various sources, for TDLAS using a 1 meter gas cell are listed in Table 3.

\begin{tabular}{|l|l|l|}
\hline Gas & Wavelength, $\lambda(\mu \mathrm{m})$ & Detection Limit $(\mathrm{ppm})$ \\
\hline $\mathrm{NH}_{3}$ & 1.5 & 0.8 \\
\hline $\mathrm{CO}_{2}$ & 1.96 & 3.0 \\
\hline $\mathrm{CO}$ & 1.57 & 3.0 \\
& 2.33 & 0.5 \\
\hline $\mathrm{CH}_{4}$ & 1.65 & 0.6 \\
\hline $\mathrm{NO}$ & 1.8 & 60 \\
& 2.65 & 1.0 \\
\hline $\mathrm{NO}_{2}$ & 0.68 & 0.3 \\
\hline $\mathrm{N}_{2} \mathrm{O}$ & 2.26 & 1.0 \\
\hline $\mathrm{O}_{2}$ & 0.76 & 80 \\
\hline $\mathrm{H}_{2} \mathrm{O}$ & 1.39 & 0.06 \\
\hline
\end{tabular}

Table 3: Typical Measurements with Various gas Concentrations 
COTS components, shown in Figures 43 and 44, were used to interface a vertical-cavity surfaceemitting laser (VCSEL) to a 400 micron fiber optic fiber. The VCSEL operates at $2004 \mathrm{~nm}$. Light from the fiber was focused into a 500 micron I.D. hollow wave guide, from Polymicro Technologies, used as the gas cell. Additional off-the-shelf components were used to connect the photodiode detector to a fiber optic cable.

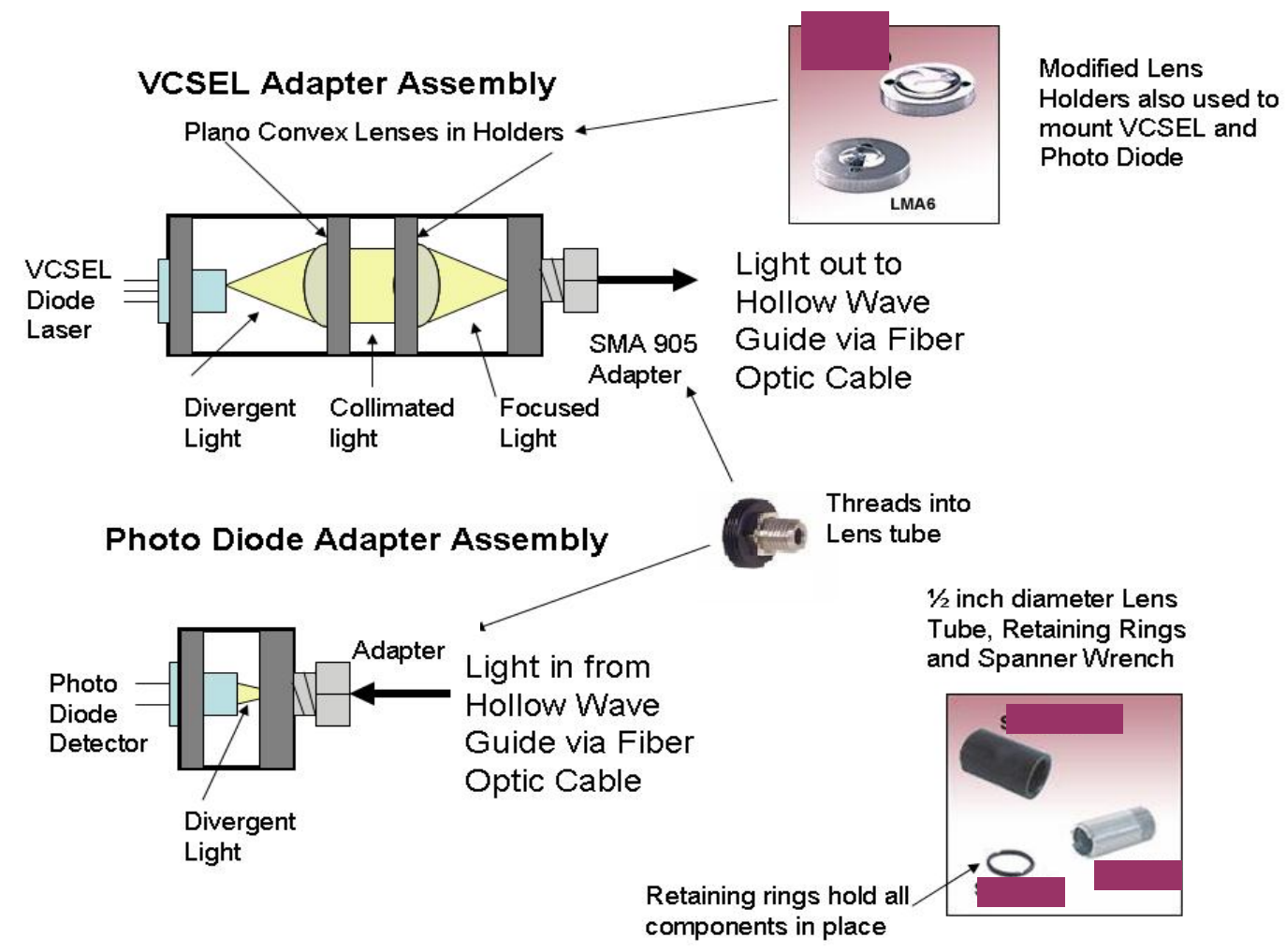

Figure 43. COTS Components for Interfacing to Fiber Optics 


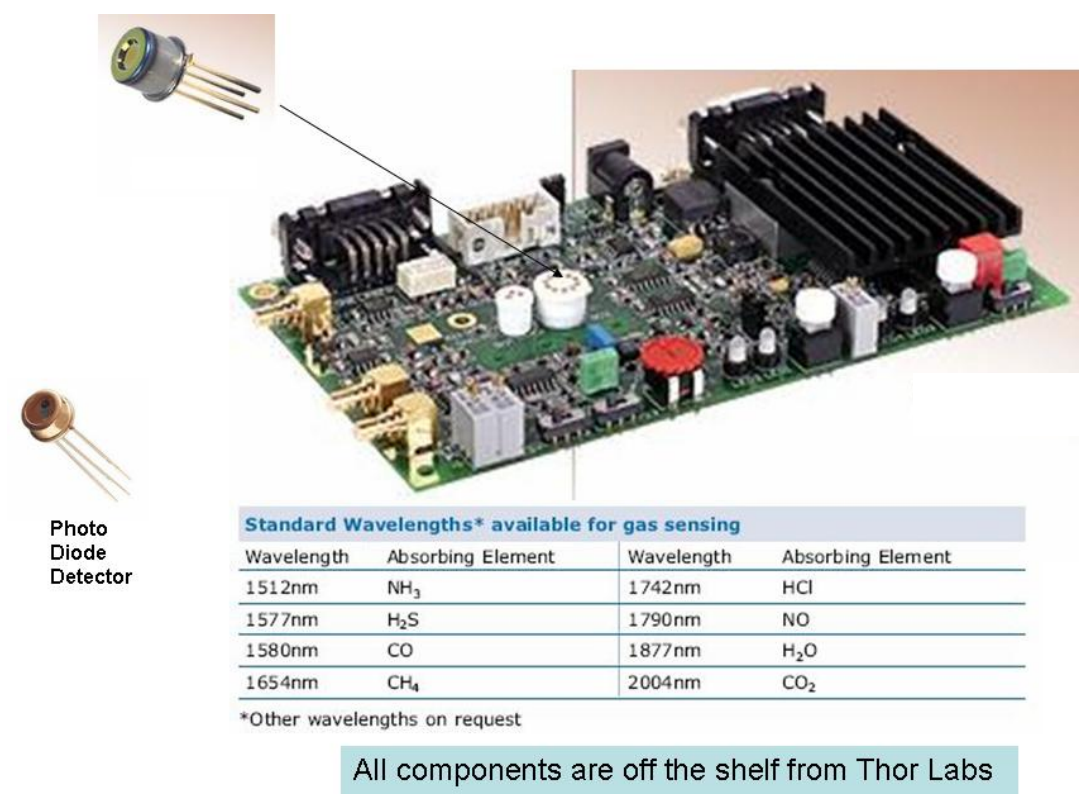

Figure 44. VCSEL Laser Diode Controller and Photodiode Detector

The 450 micron O.D. fiber was placed in the end of the 500 micron I.D. hollow waveguide. A bent syringe was placed beside the fiber in front of the hollow waveguide and sealed with heat shrink tubing shown in Figure 45. Another 450 micron O.D. fiber was inserted into the opposite end of the hollow waveguide. The path length of the gas cell was $15 \mathrm{~cm}$. Helium was flowed through the syringe to flush out air from the hollow wave guide. Light output was measured on a photodiode detection system. With the helium flow the detection system measured $300 \mathrm{nW}$. The helium flow was disconnected and room air, containing $385 \mathrm{ppm} \mathrm{CO}_{2}$, was allowed to enter. The detection system showed a $4 \mathrm{nW}$ decrease in light intensity. Based on detection limits in the literature, 200 ppm $\mathrm{CO}_{2}$ would be able to be detected with a $15 \mathrm{~cm}$ path length.

This system was to be used to evaluate hermetic sealing options for delivering the laser light to a hollow wave guide inside a sealed container. An additional VCSEL for water also was evaluated. Utilizing the hollow waveguide-VCSEL methodology proved effective for detecting carbon dioxide gas, additional VCSEL's were identified with lasing wavelengths that should be capable of detecting other gases of interest. A second VCSEL source was obtained with a different output wavelength specific for water. A photodiode amplifier with both digital and analog outputs also was ordered to allow test data recording. An IO Tech DAQ was interfaced to the photo diode amplifier to allow real-time data acquisition. 


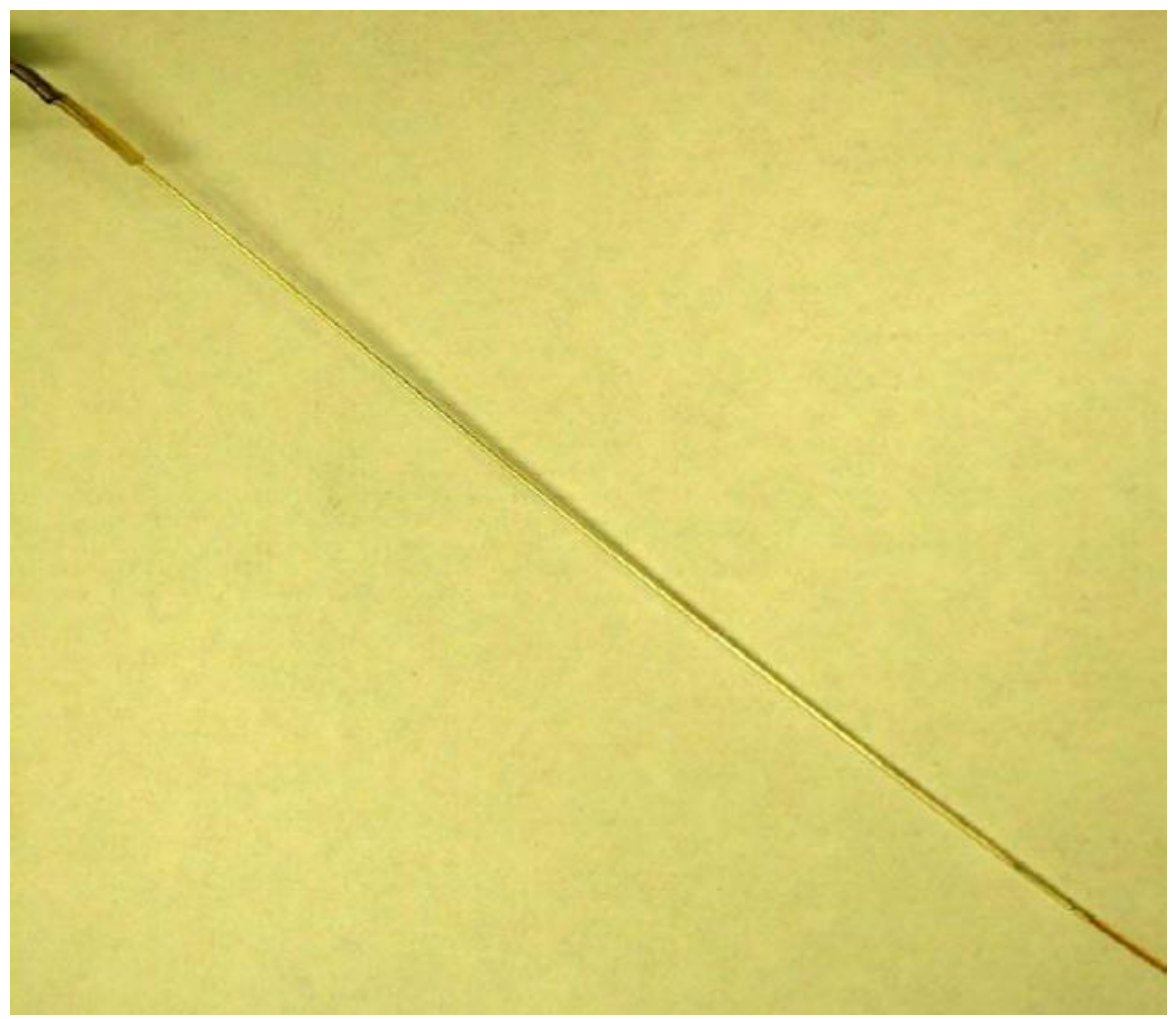

Figure 45. Hollow Fiber Gas Cell

An initial repeatability of approximately $4 \%$ has been obtained when measuring atmospheric carbon dioxide (approximately 350 ppm) shown in Figure 46.

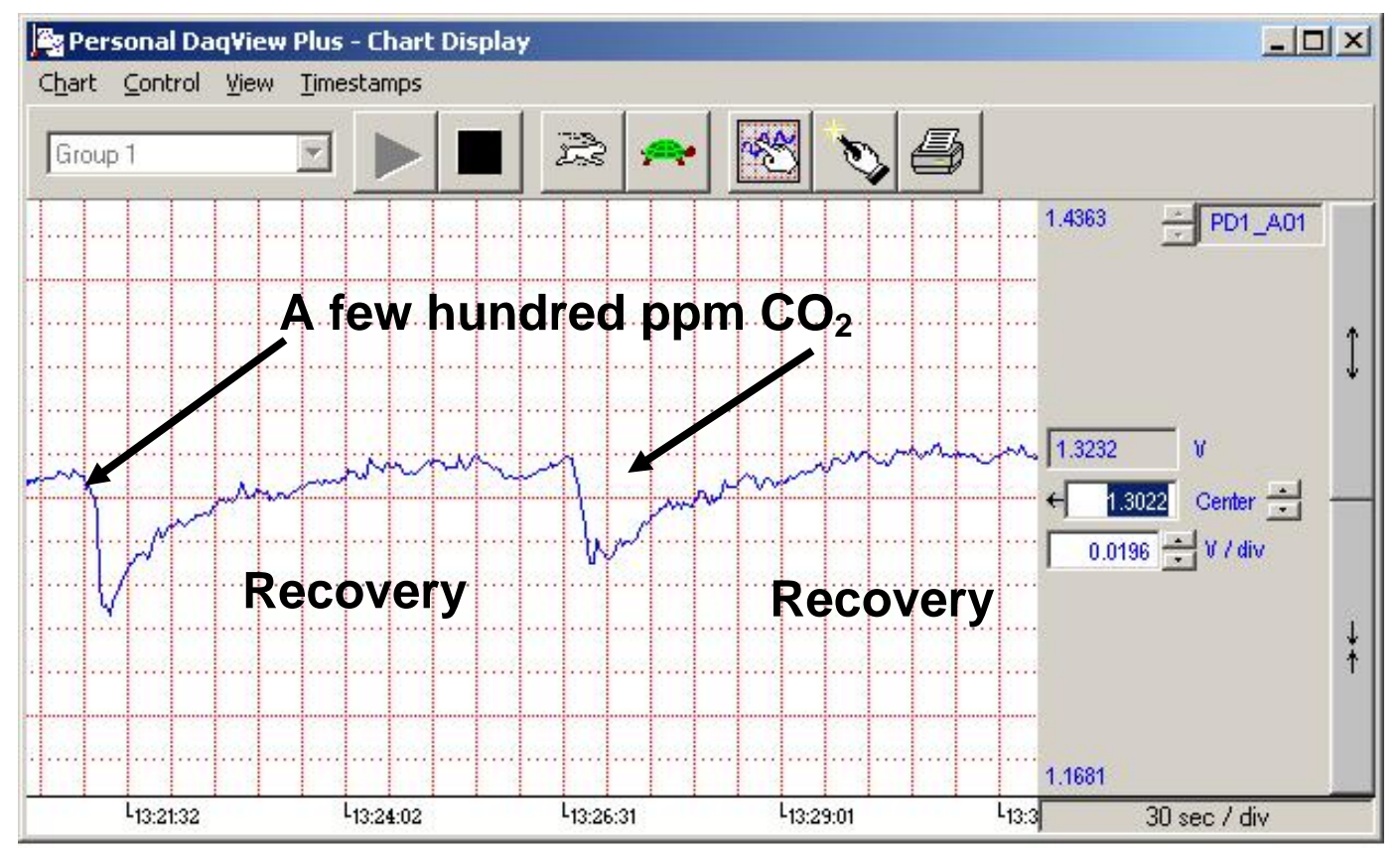

Figure 46. Response to Carbon Dioxide 
The optics required for $\mathrm{H}_{2} \mathrm{O}$ sensing was assembled and the VCSEL controller was mounted into an electrical isolation box. Detection of $\mathrm{H}_{2} \mathrm{O}$ was demonstrated using the VCSEL diode laser at $1877 \mathrm{~nm}$.

Stainless steel tubing and gas fittings where assembled to house the hollow wave guide. The initial design used epoxy to seal the optical fibers from the VCSEL and the photodiode detector to stainless steel Swagelok plugs. Drill bits, 0.0189 inch in diameter, were obtained and used for drilling holes in a stainless steel plug shown in Figure 47. The optical fiber was bonded into these plugs to give a semi-hermitic seal shown in Figure 47. The fiber was first bonded to the flat side of the plug, it was then inverted and vacuum encapsulated on the interior of the plug and assembled into a stainless steel gas cell shown in Figure 49.
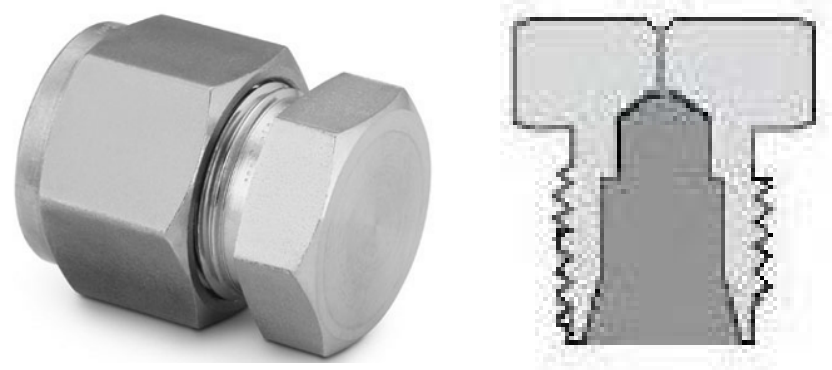

Figure 47. Stainless Steel Plug
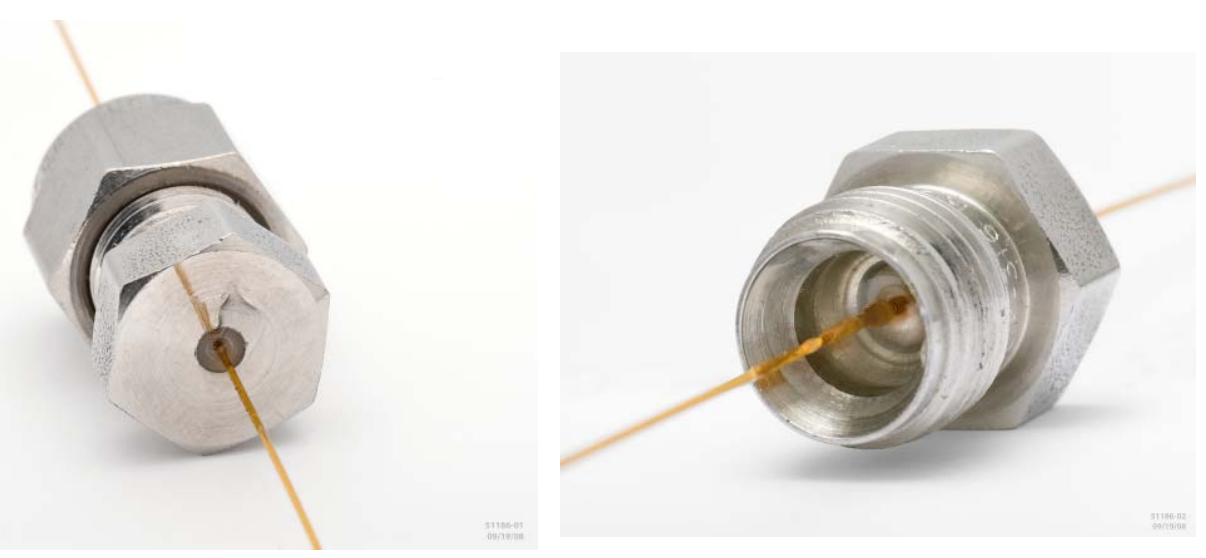

Figure 48. Fiber Bonded to Stainless Steel Plug 


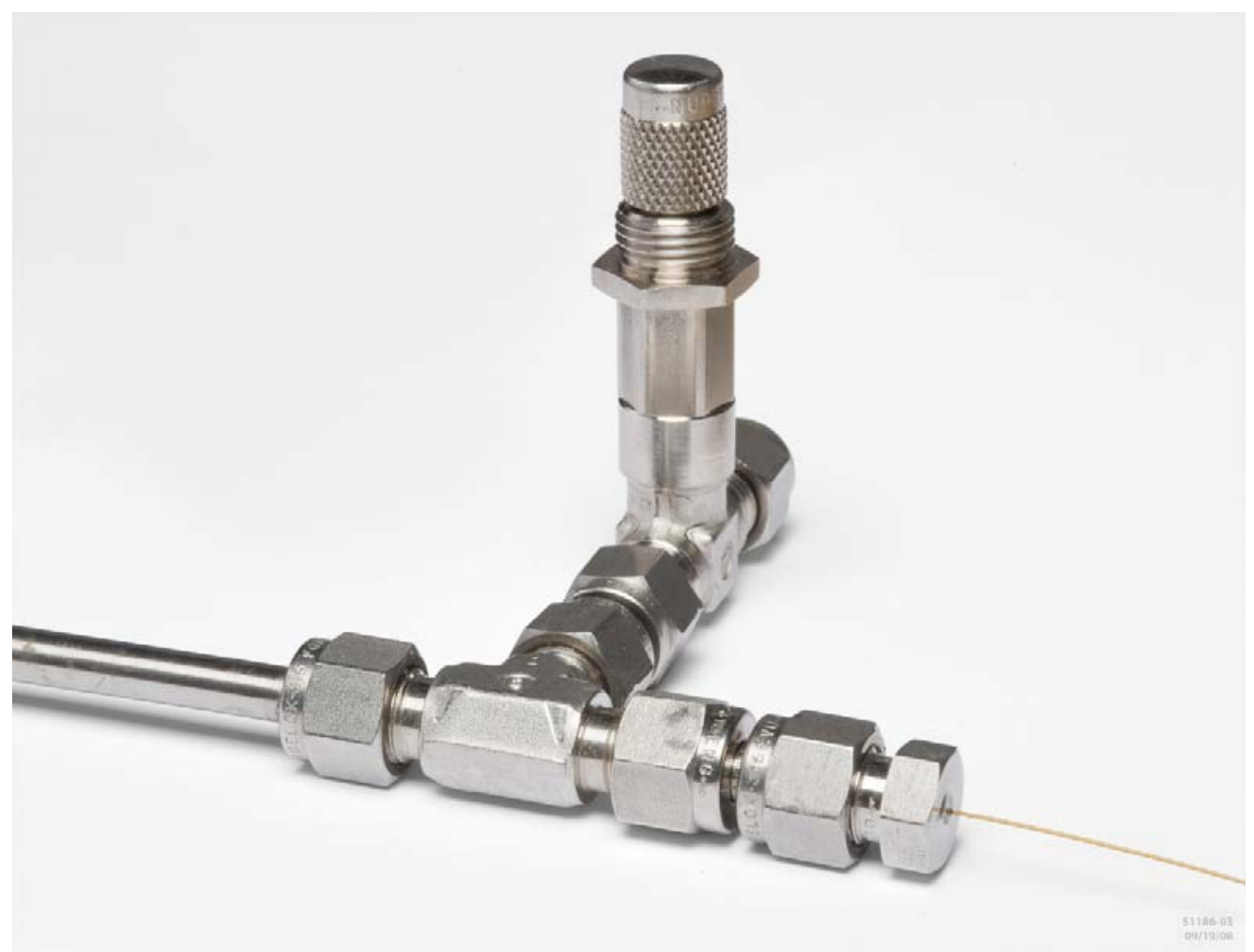

Figure 49. Stainless Steel Gas Cell with Hollow Wave Guide Inside

\section{Commercial Hermetic Fiber Optic Connectors}

Data was gathered from searches on the internet on the availability and specifications for commercial hermetic fiber optic connectors. This data was placed in a database for selection purposes. There are 100 COTS feed-throughs in the database. The database contains the names of the supplier, brand name, cost, connector, fiber profile, mode, fiber diameter, connector material, hermeticity, wave length range as well as other information. This data base is listed in Appendix A. Two feed-throughs were selected for in-house testing based on hermeticity and upper temperature use. Testing was performed on a FO1 and a Bolt-1 from Accuglass. These feed-throughs are shown in Figures 50 through 51.

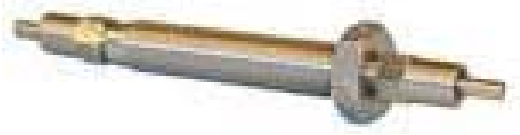

Figure 50. Bolt-1 Hermetic Feed-Through 


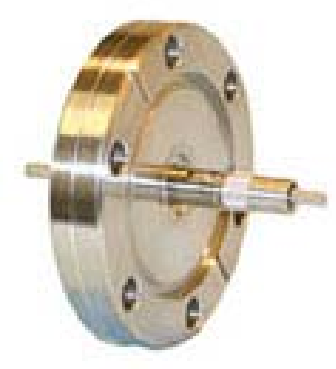

Figure 51. FO1 Hermetic Feed-Through

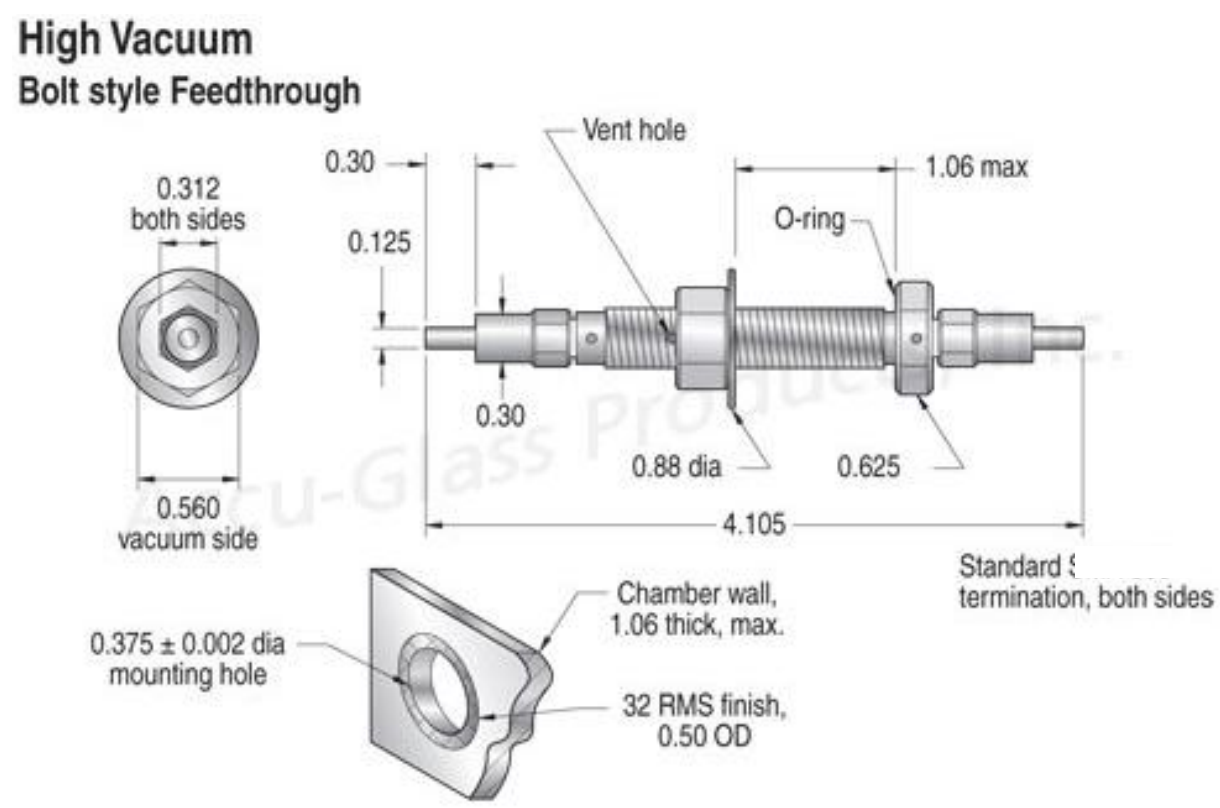

Figure 52. Dimensions of Bolt-1 Feed-Through 


\section{Ultrahigh Vacuum \\ CF Flange Feedthrough}
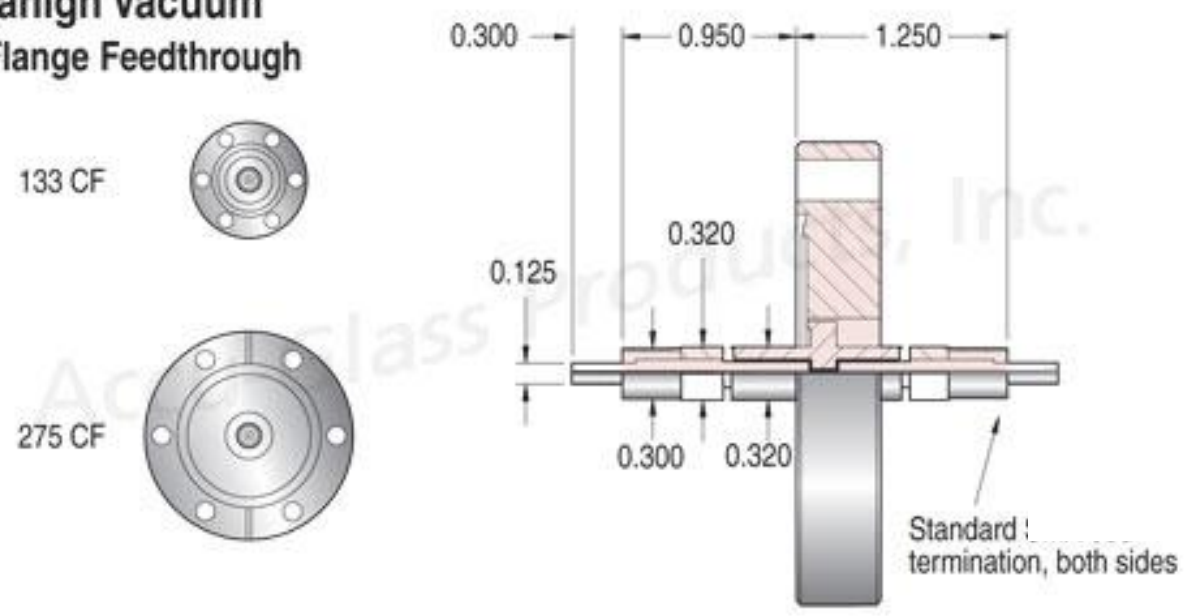

Figure 53. Dimensions of FO1 Feed-Through

\section{Leak Testing and Temperature Cycling}

Both feed-throughs are certified to greater than $5 \times 10^{-10} \mathrm{std} \mathrm{cc} / \mathrm{s} \mathrm{He}$. The results of leak testing after temperature cycling are $8.2 \times 10^{-10} \mathrm{std} \mathrm{cc} / \mathrm{s} \mathrm{He}$ for the FO4IR 275 and 7 X $10^{-10} \mathrm{std} \mathrm{cc} / \mathrm{s} \mathrm{He}$ for the Bolt-1 feed-through. During vibration testing and shock testing the Bolt-1 feed-through failed optical transmission at $3300 \mathrm{G}$ 's. The FO1 survived all vibration and shock testing and had a leak rate of $4 \times 10^{-10} \mathrm{std} \mathrm{cc} / \mathrm{s}$ He. The shock and vibration data is shown in Appendix B.

The temperature was cycled twice from $-55 \mathrm{C}$ to $+75 \mathrm{C}$ with 1 hour soak at each temperature on the FO1. The feed-through was tested by sending a laser signal through it with an Ocean Optics 1 LED light source and comparing its through-put energy to original energy without feed-through. The through-put loss was measured with a Newport power meter.

Before temperature cycling readings were: $\quad 6.25 \mathrm{uW} / 8.37 \mathrm{uW}(74.7 \%)$. After temperature cycling readings were: $\quad 6.16 \mathrm{uW} / 8.40 \mathrm{uW}(73.3 \%)$.

\section{Displacement and Time of Arrival Sensors}

\section{Displacement/Gap Sensors}

Displacement and Gap sensor development and characterization was performed for three different configurations (Figure 54). An "in-line", a 90 degree, and a "bent fiber" displacement/gap senor were assembled and characterized. The performance sensitivity of the "in-line" displacement/gap sensor was characterized utilizing a number of different focal length lenses (Figure 55). 
Techniques for bending fibers to obtain very small radius of curvature loops (Figure 56) were investigated as an enabling process for fabricating "bent fiber" displacement/gap sensors. A furnace and a $\mathrm{CO}_{2}$ laser were the two different heating methods evaluated for creating permanent bends in the optical fibers. While the $\mathrm{CO}_{2}$ laser can be applied in a more localized area, the furnace also had some advantages. Utilizing the furnace, it was possible to achieve smaller bends as the heating tended to relieve a portion of the stress in the fiber attributed to micro-bending. Several multi-mode and step-index fibers with different core diameters were tested. 25 micron, 50 micron and 100 micron diameter fibers were used to obtain small, medium and large diameter bends. The optical transmission loss as a function of bend radius and fiber diameter was investigated. A qualitative evaluation of the fiber's post-bending strength was also noted.

Clearly the stress is very high for small bends in these fibers. Firing the fibers in the furnace tends to relieve some of the stress. Unfortunately, the firing process removes the protective polymer coating. When this coating is removed, the fibers become brittle and are very easily damaged. It has been suggested that if the fibers are re-coated, that some of the strength may return. This remains an area of interest and planned future investigation. 

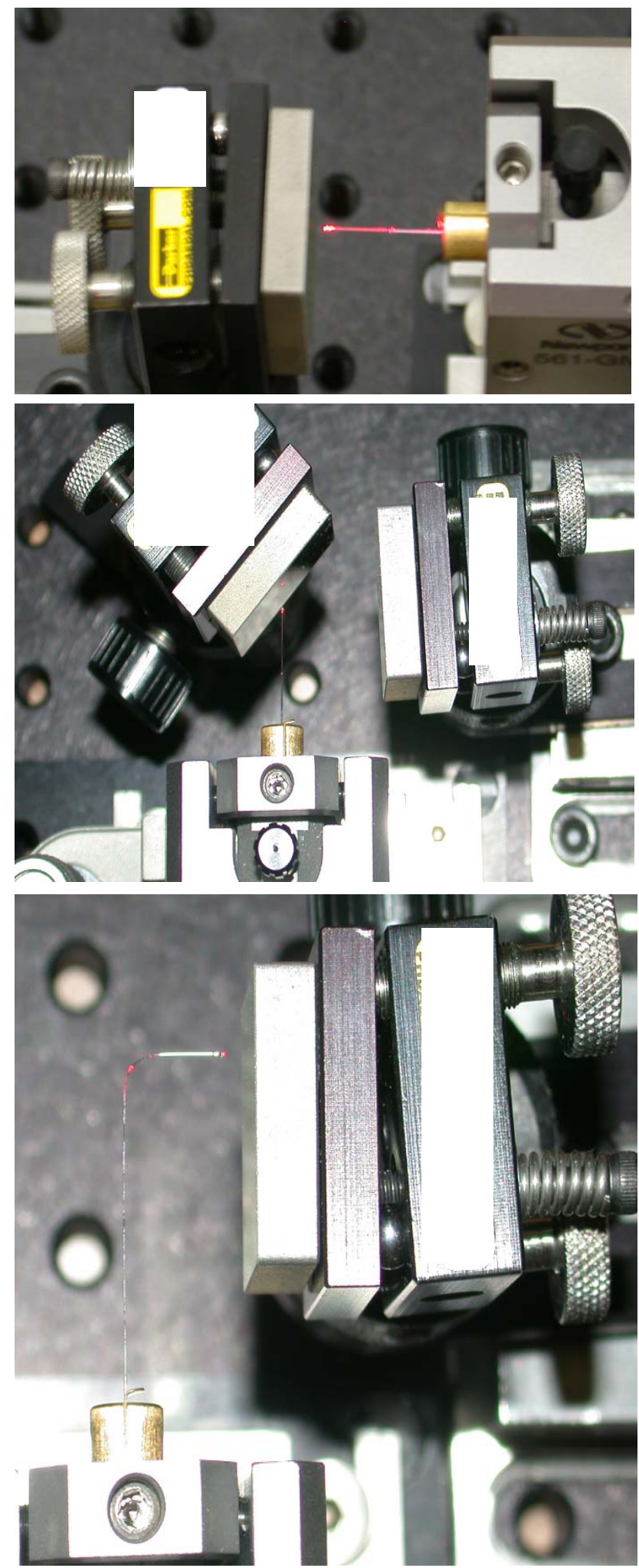

Figure 54. Fiber Based "in-line", 90 degree, and "Bent Fiber" Displacement/gap Sensors 


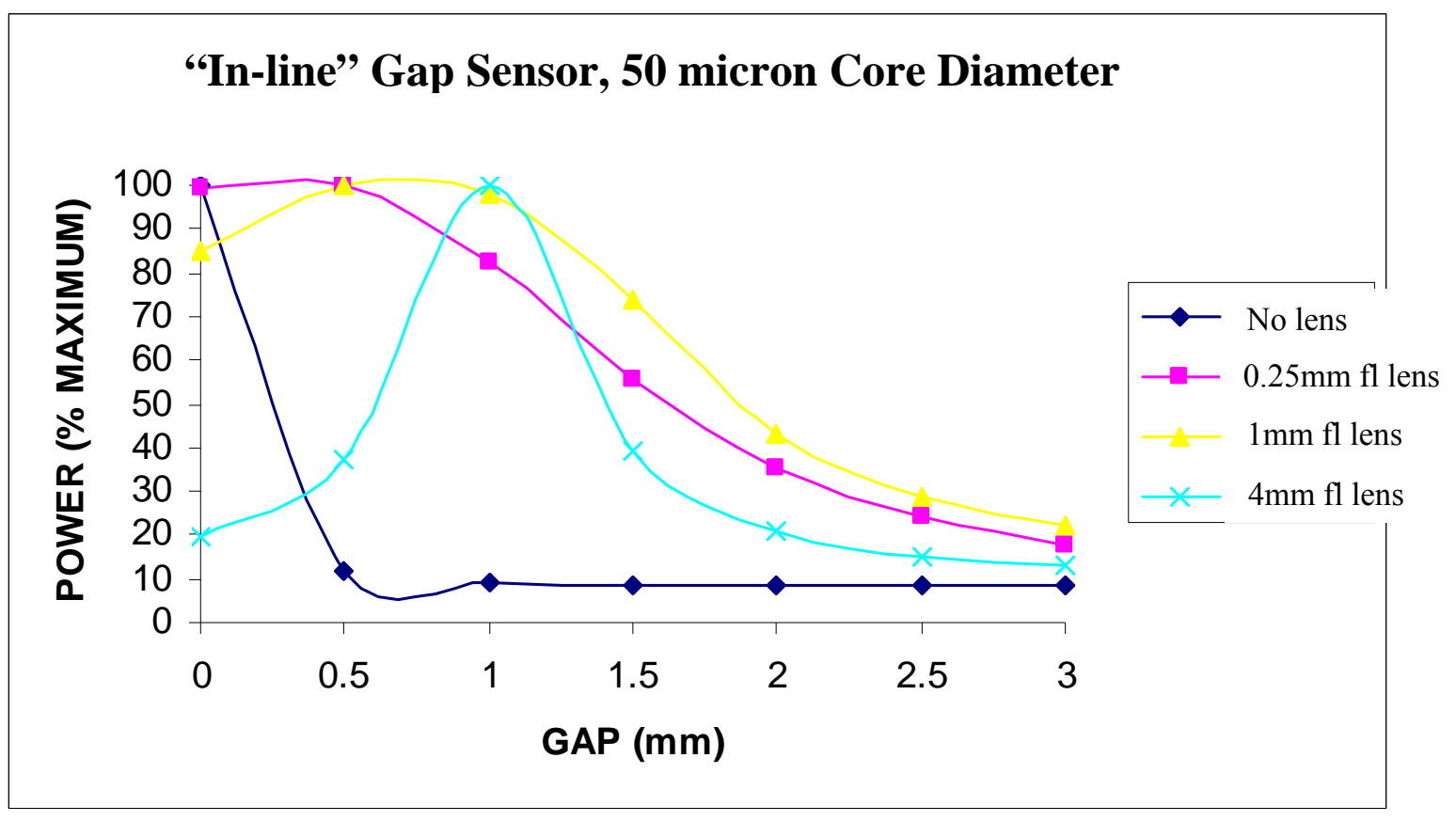

Figure 55. Performance of the "in-line" Displacement/gap Sensor for Different Focal Length Lenses

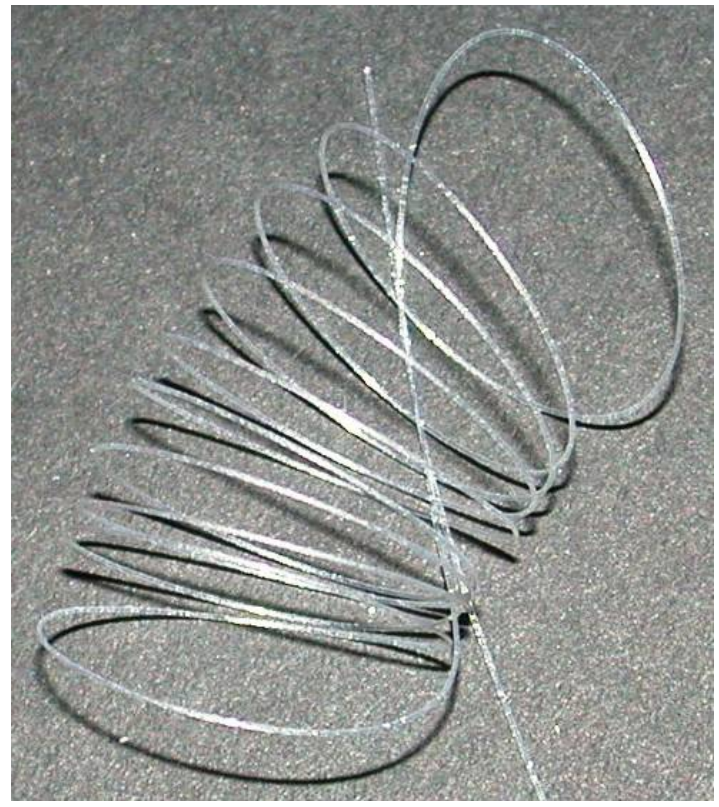

Figure 56. Small Diameter Loops Obtained by Firing Multi-Mode Fiber in a Furnace 


\section{PTOA Sensors}

PTOA sensors were designed, built, and tested. Samples sensors were shipped to LANL for further evaluation. Previous TOA sensors were bonded tangent to the explosive being evaluated. This project required the sensors to come in perpendicular to the explosive without being bonded to it. A spring loaded PTOA was designed and works in a way that is similar to a spring loaded electrical contact (commonly called a pogo). Figure 57 indicates the final design that was implemented.

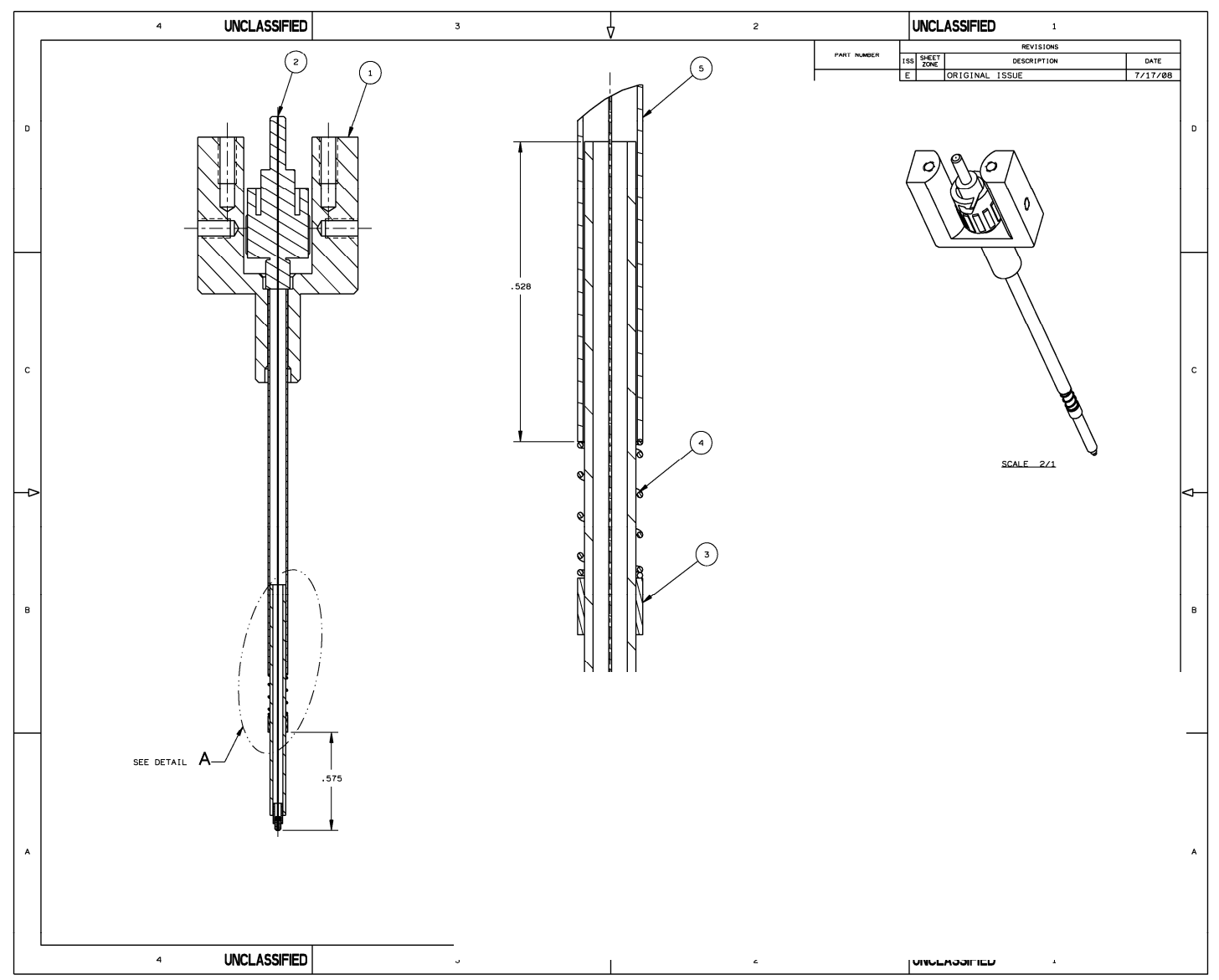

Figure 57. PTOA Sensor

Figure 58 shows how the PTOA could be installed in a simulated assembly entering through a guide with the probe extended for use. 


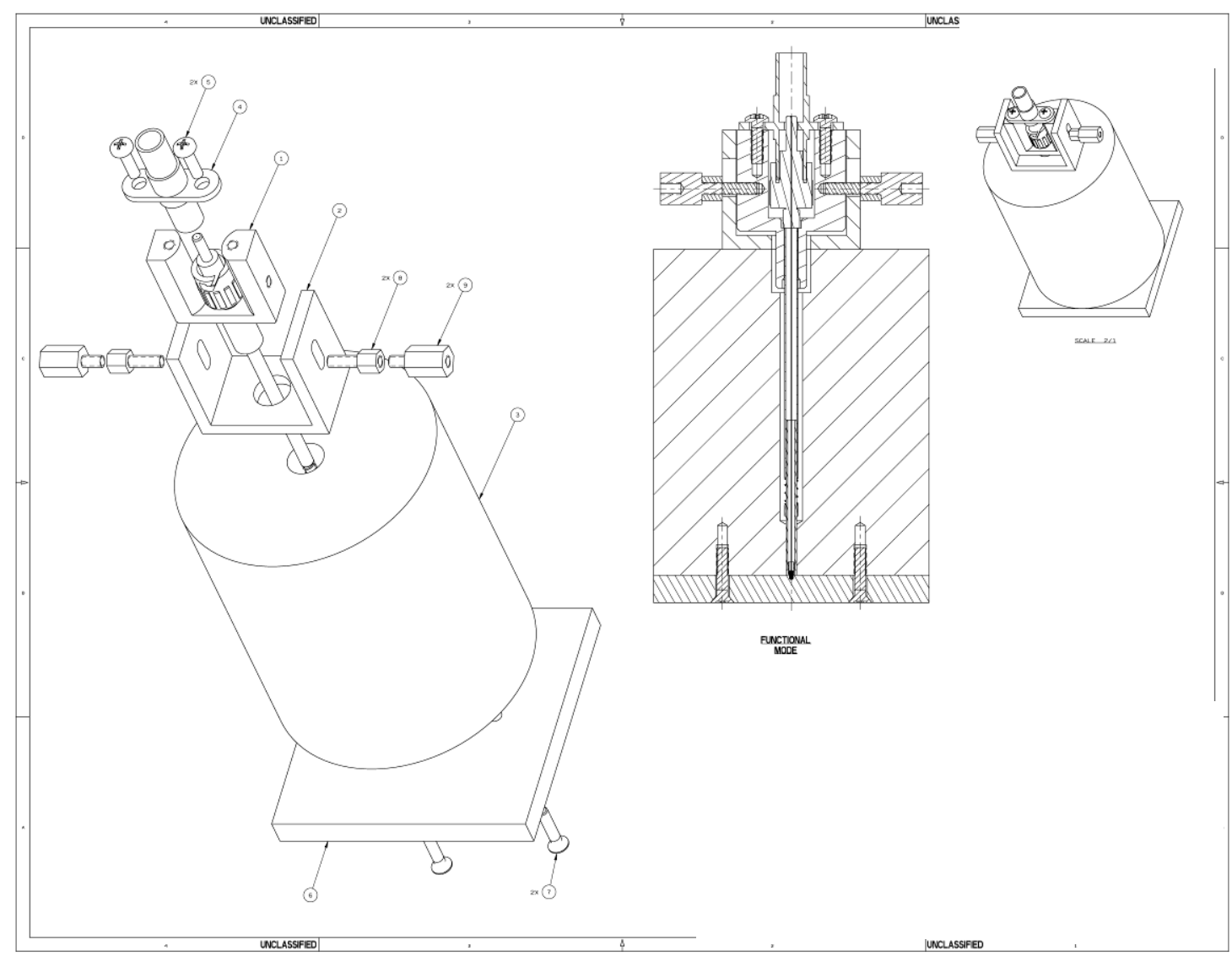

Figure 58. PTOA Installed in a Simulated Next Assembly. The Cross-Section View Shows the PTOA in the Down Position

The cross-section view of the installed PTOA shows it extending into the material at the bottom of the hole. In reality, the spring would compress and the PTOA probe tip would contact the material but would not go into it. This view shows the down (or engaged) mode of the PTOA. The customer also wanted to raise the sensor and hold it in that position for shipment. Figure 59 shows the sensor locked in the up position for transportation purposes. 


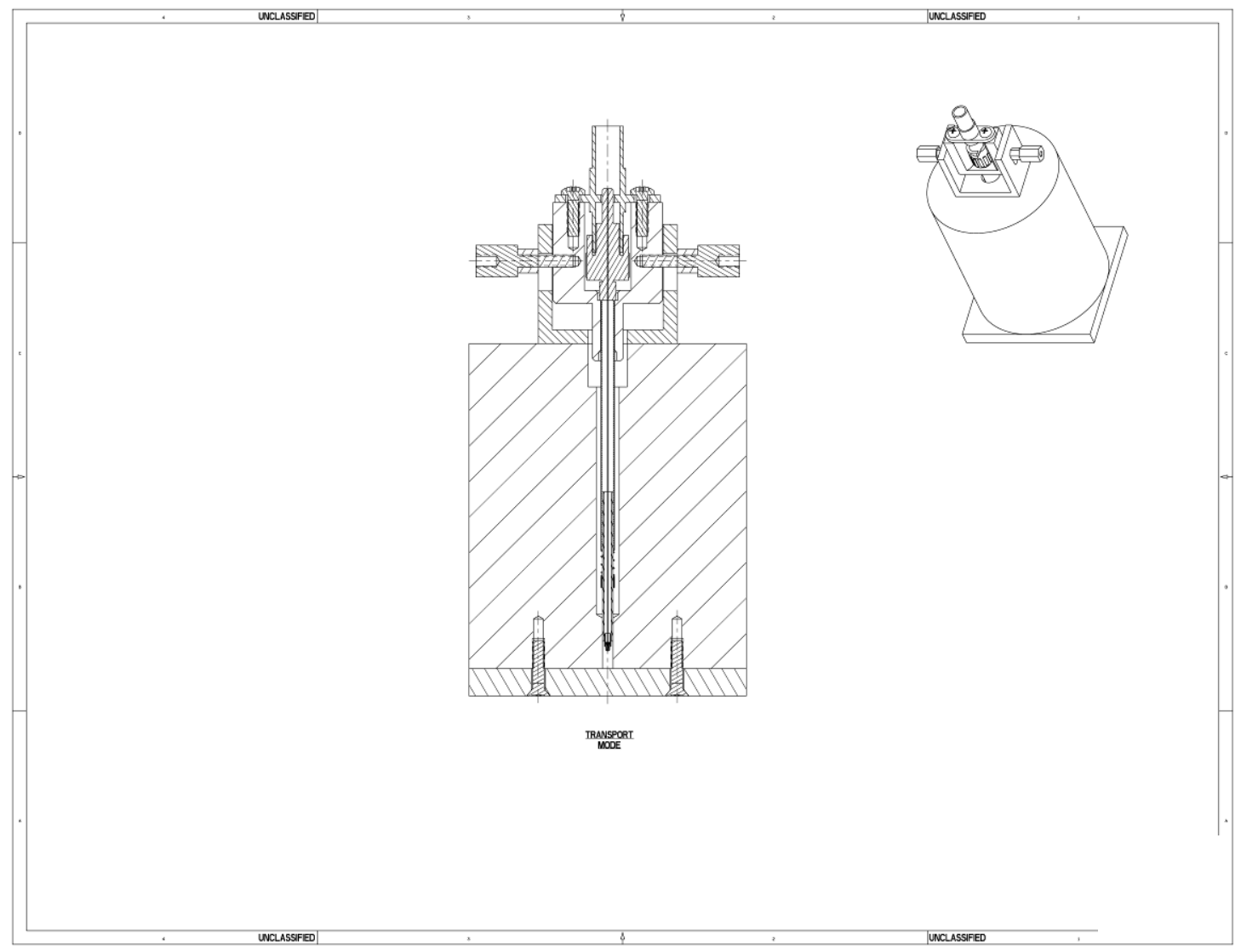

Figure 59. PTOA is in the up Position (for Transport)

Figure 60 shows an actual PTOA assembly that was built, tested, and shipped to LANL for testing.

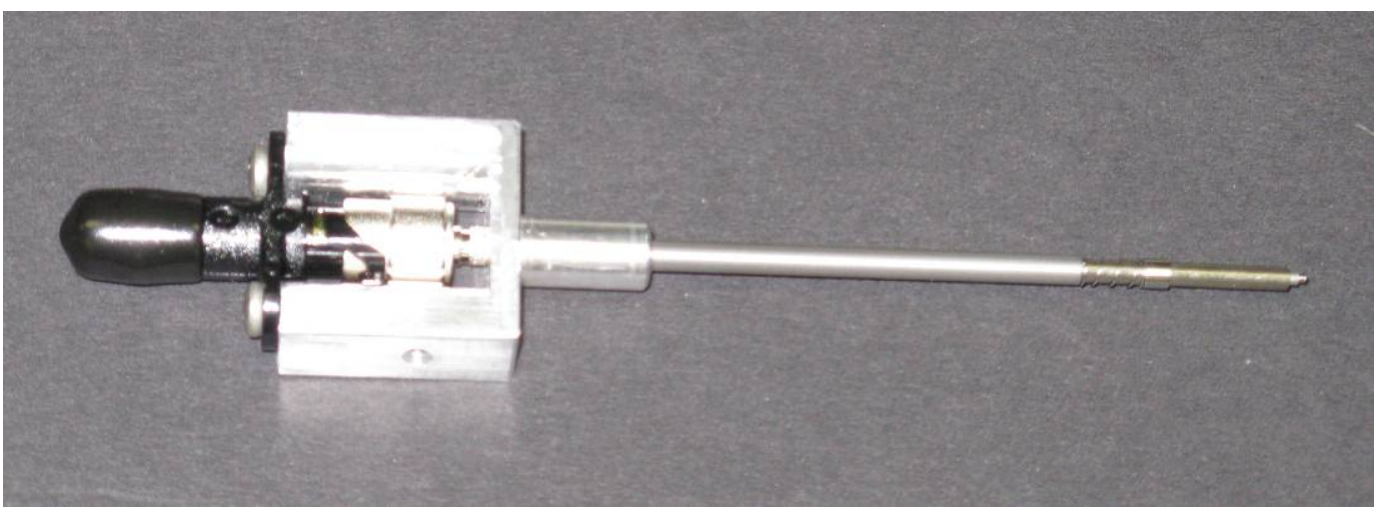

Figure 60. PTOA Sensor

To keep the probe from extending into the material, a spring loaded tip was employed. Figure 61 shows a closer view of the spring assembly and sensor tip. 


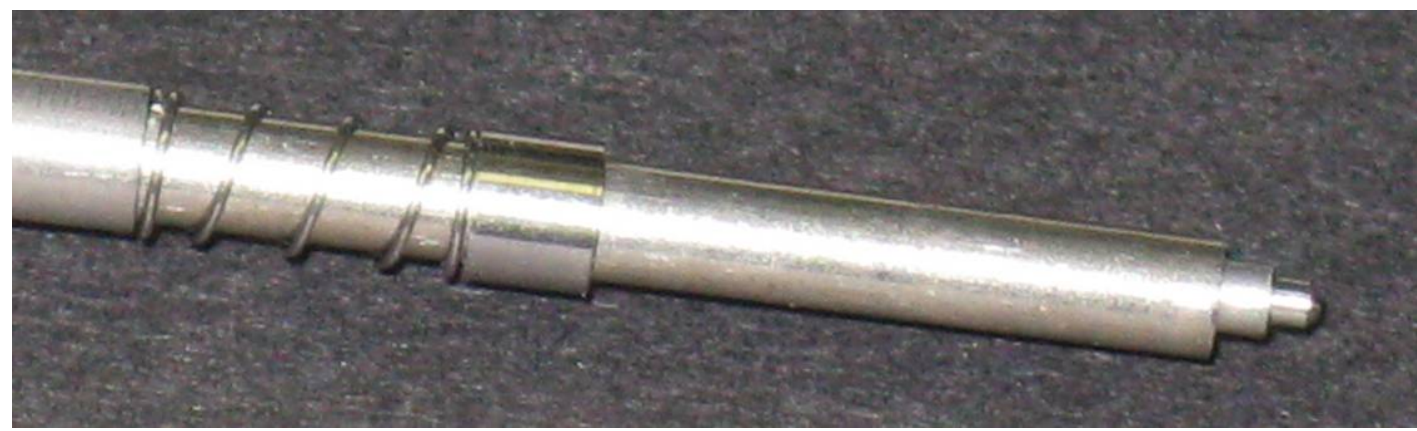

Figure 61. PTOA Spring and Sensor tip

Assembly of the PTOA sections required tooling and delicate handling of the probe parts. Figure 62 shows a fixture used to assemble the tube to the adapter.

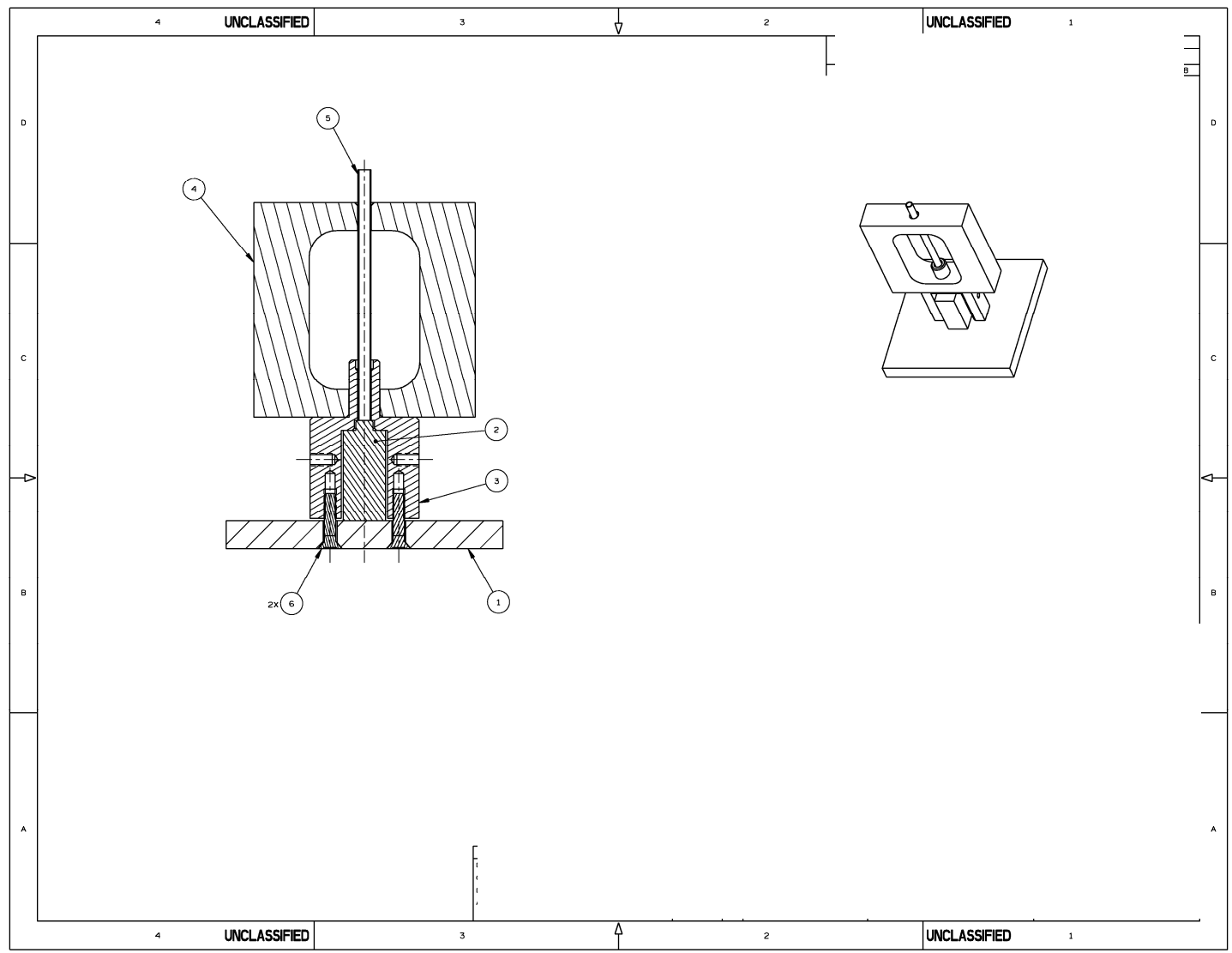

Figure 62. Tube Assembly Fixture (and a Cross-Section View) 
Figures 63 and 64 show the fixture used to align the sleeve to the tube.

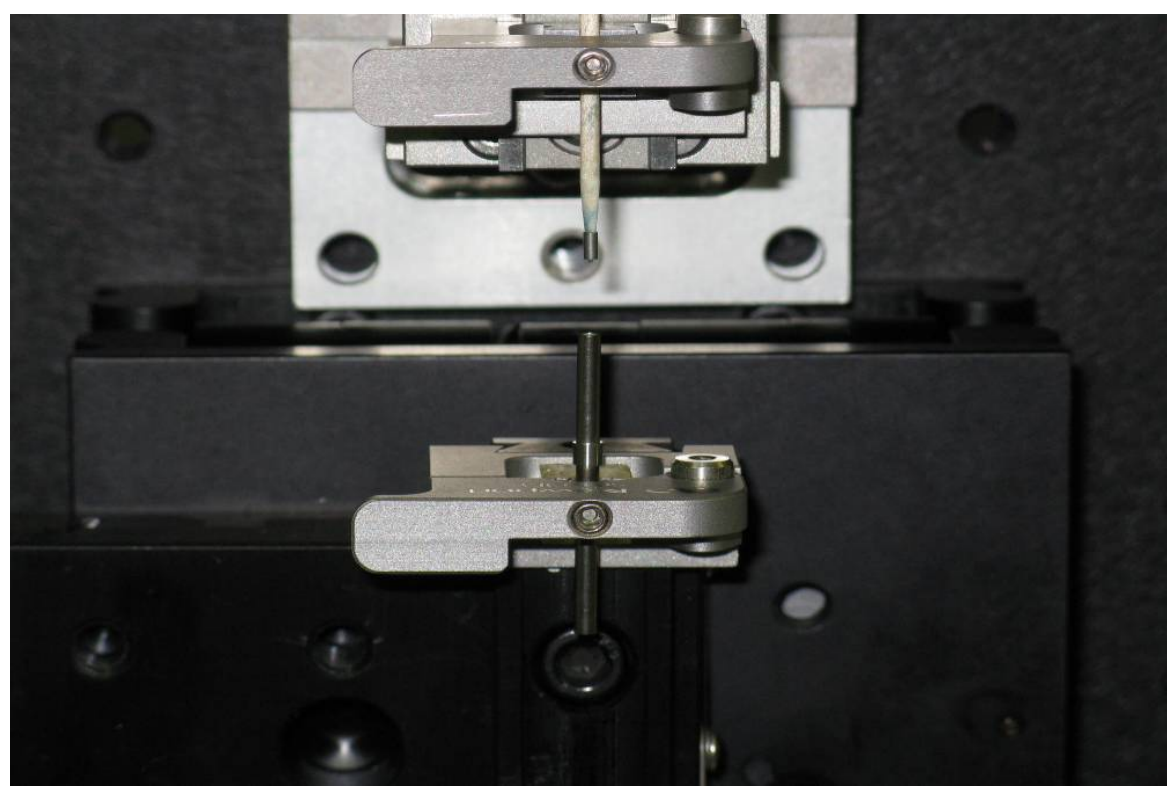

Figure 63. Sleeve to Tube Alignment Fixture

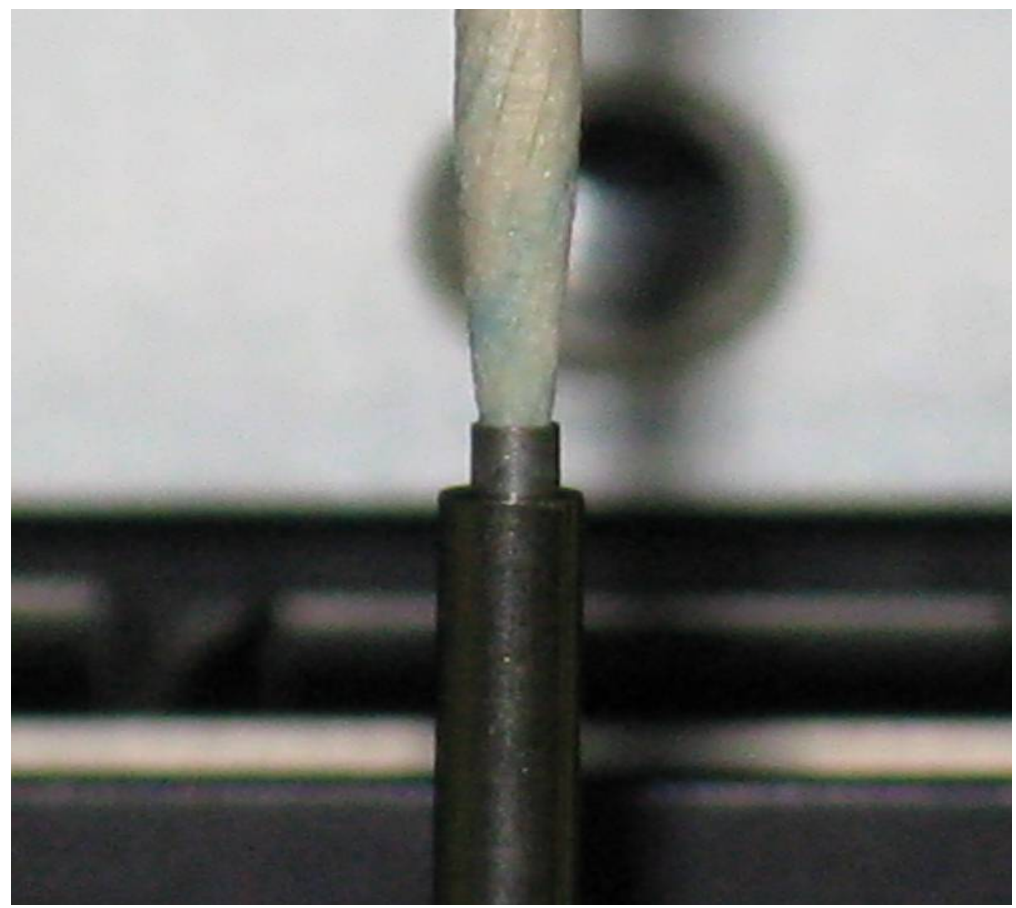

Figure 64. Sleeve to Tube Alignment Fixture (Close-up View) 
Figure 65 shows the bond material being injected into the ST connector to hold the fiber in place.

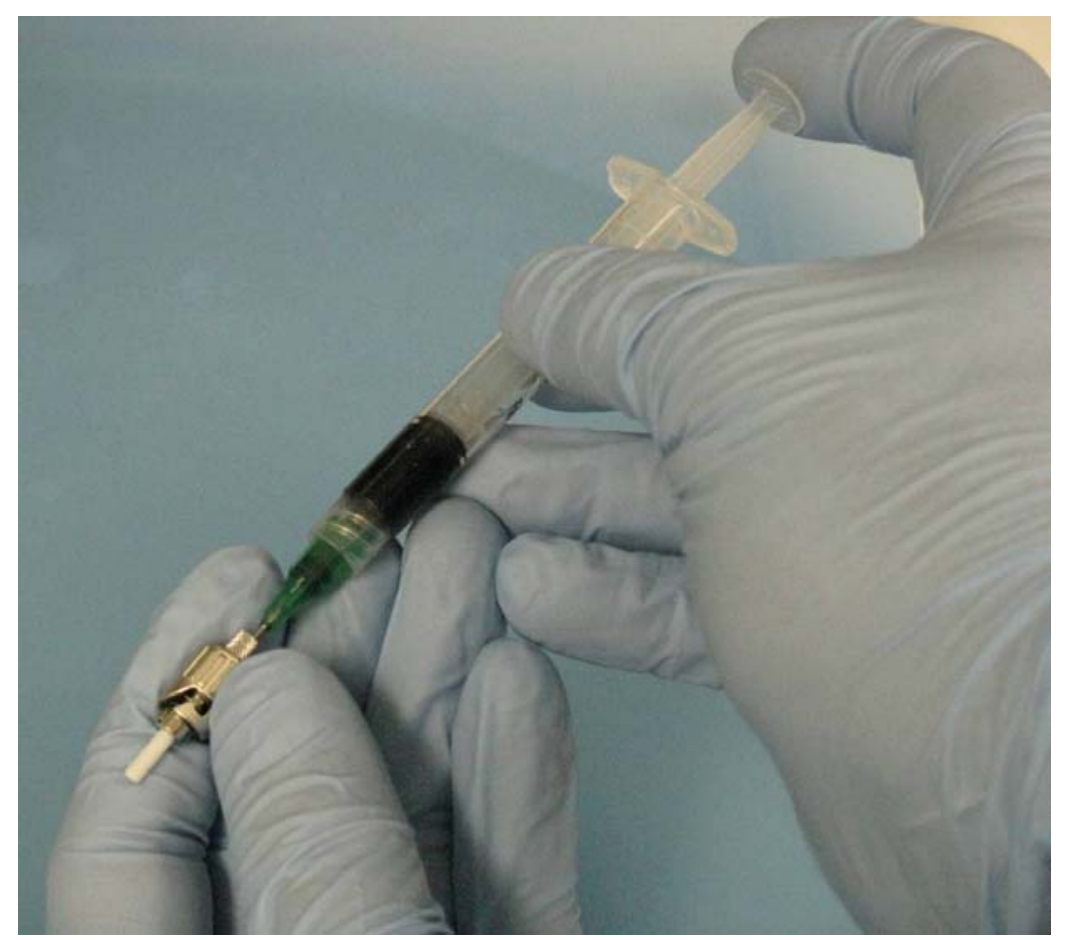

Figure 65. Bond Material was Added to the ST Connector (to Hold the Fiber in Place)

Figure 66 shows the PTOA assemblies attached to ST connectors. Protective covers must be used to avoid damage to the assembly during the polishing of the fiber tip, as shown in Figure 67. 


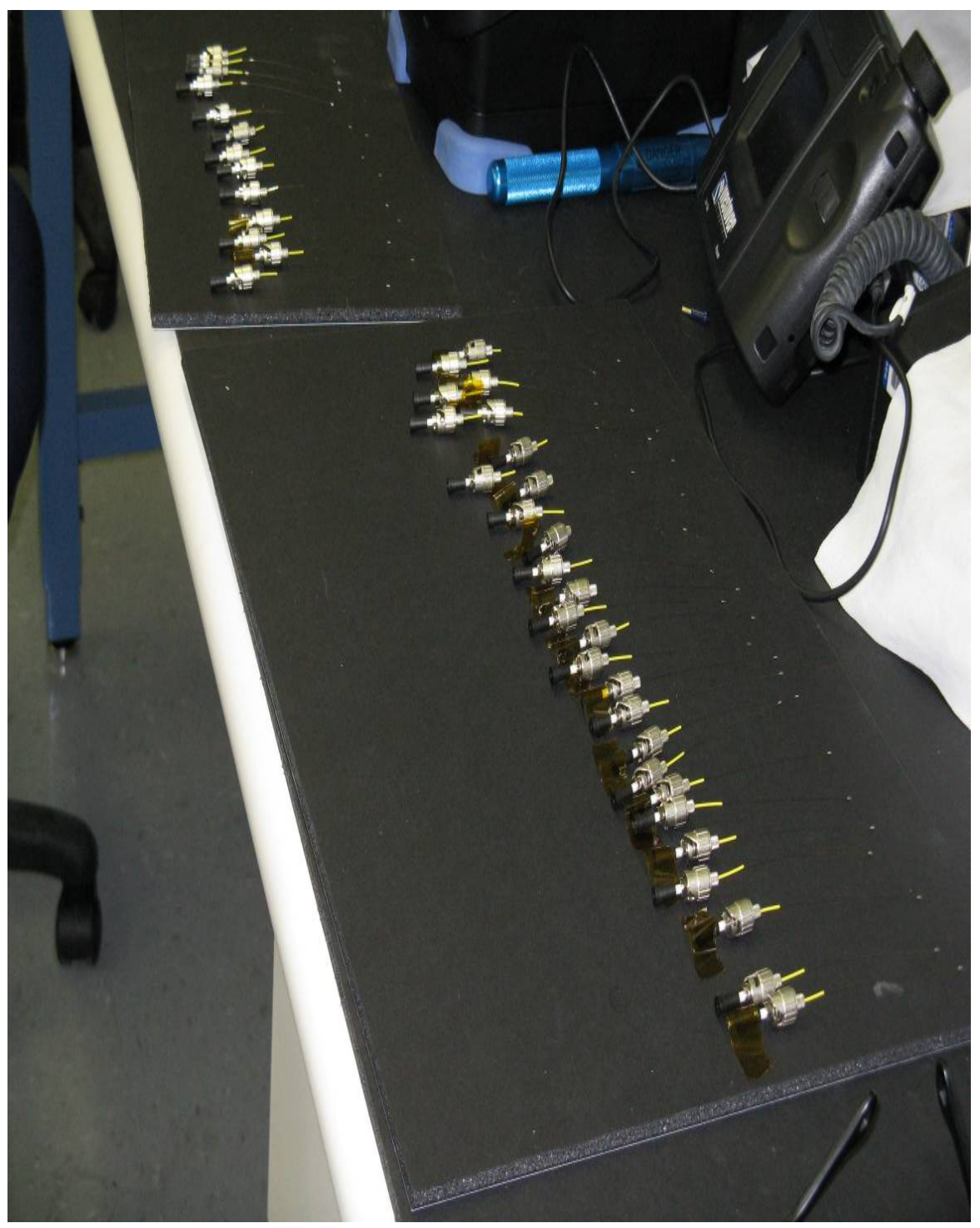

Figure 66. PTOA Assemblies Attached to ST Connectors

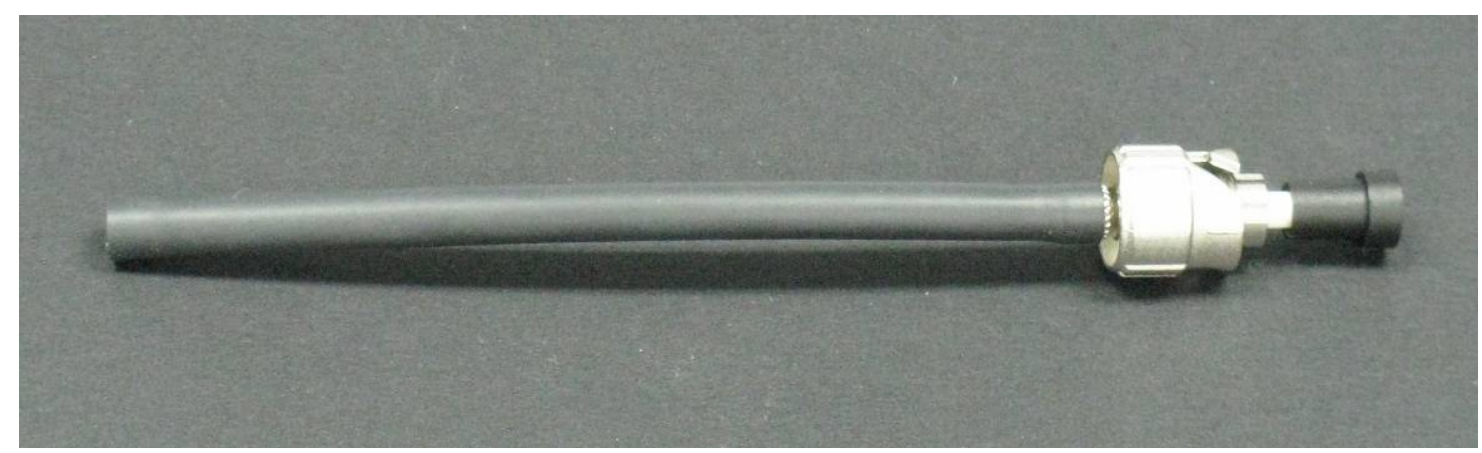

Figure 67. PTOA Protected for Polishing by a Plastic Tube 
Figure 68 shows the PTOA attached to the special polishing fixture. From there, the fiber face of the PTOA is polished using a very fine abrasive disc. Figure 69 shows the PTOA ST connector being polished, and Figure 70 shows the results looking through a polished fiber.

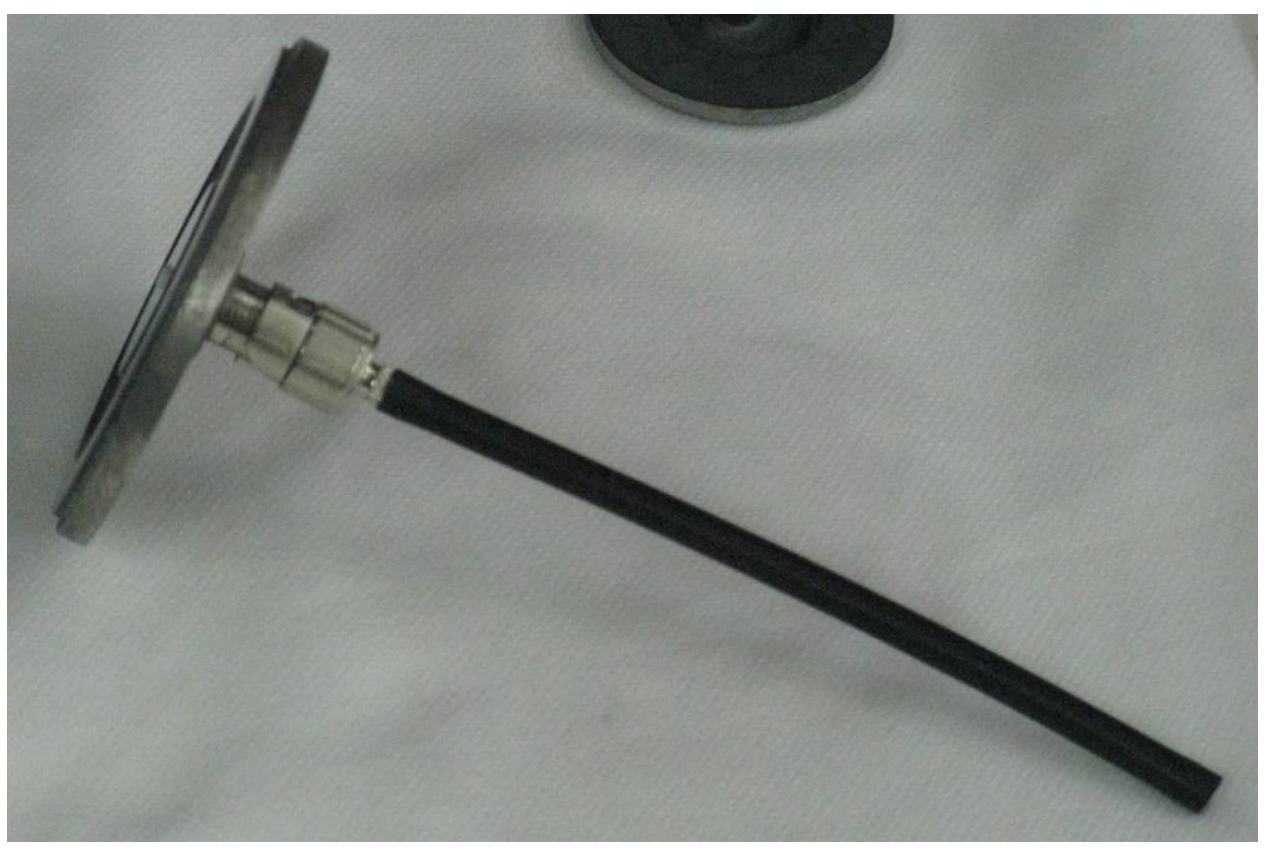

Figure 68. PTOA Attached to the Polishing Fixture

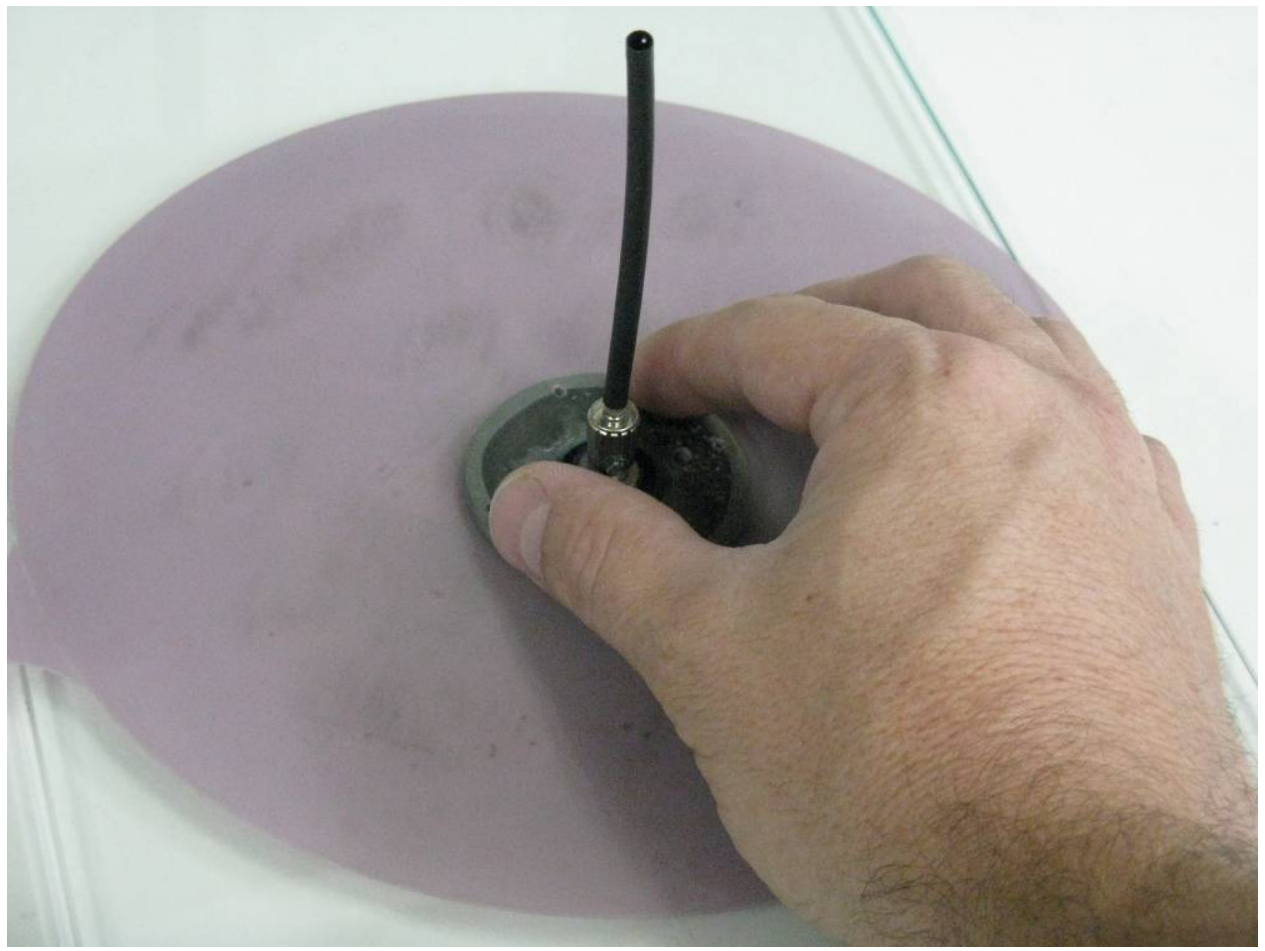

Figure 69. PTOA ST Connector Being Polished 


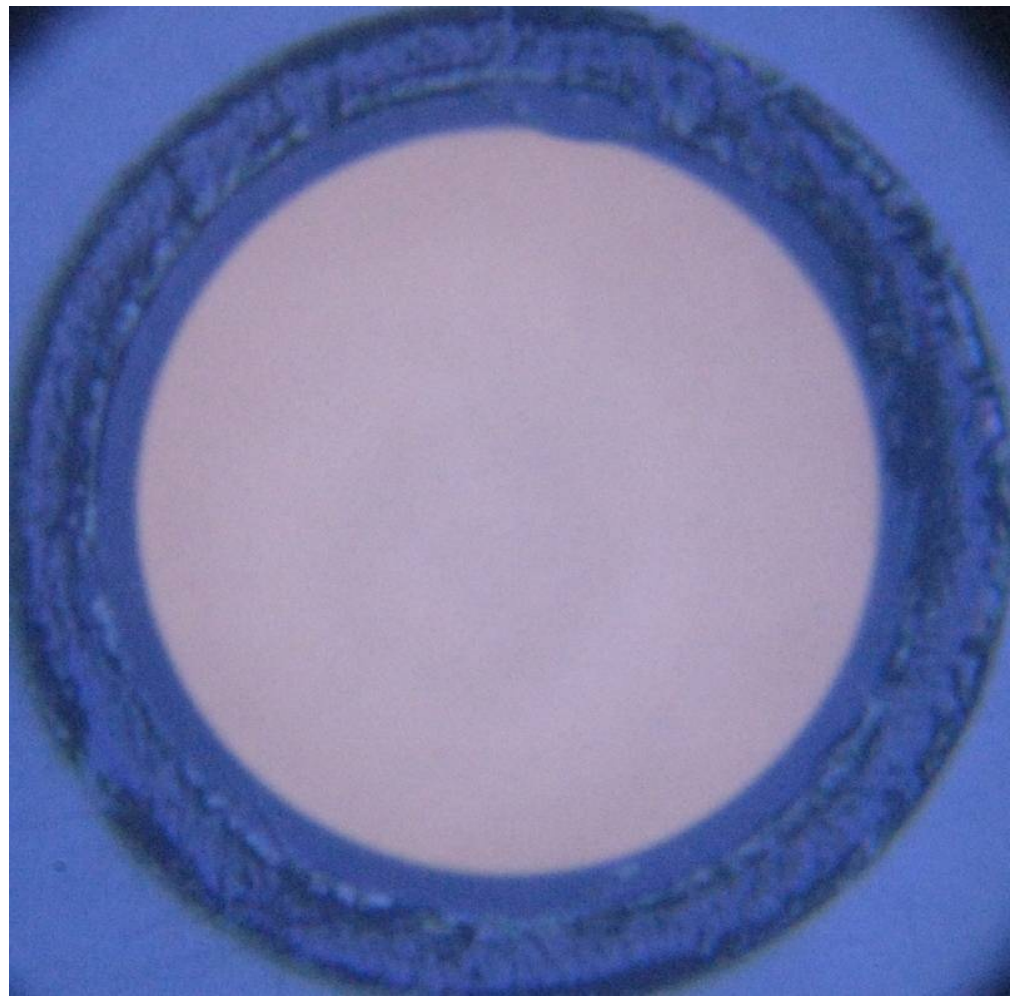

Figure 70. Visible Light Transmission Through the PTOA Polished Fiber 
The next assembly is shown in Figure 71 and Figure 72 show the entire PTOA sensor assembly in the tip alignment fixture.

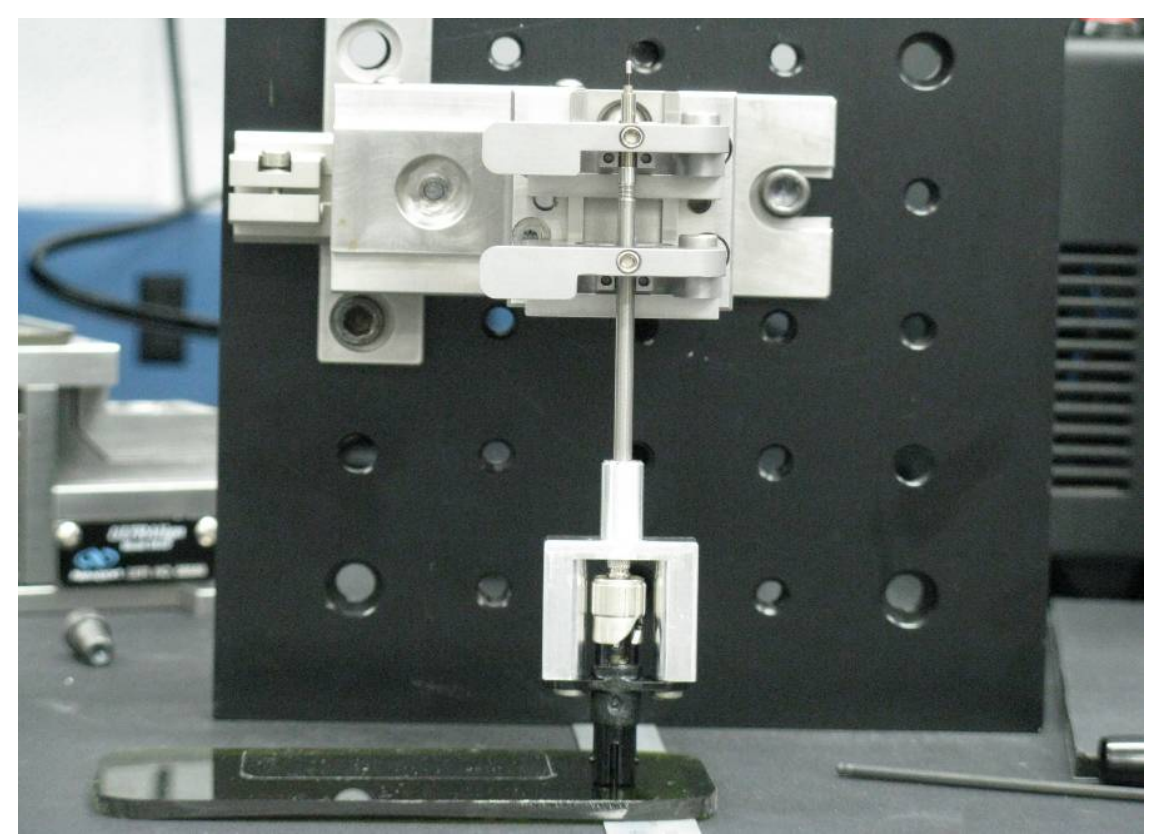

Figure 71. PTOA Sensor Tip Alignment Fixture

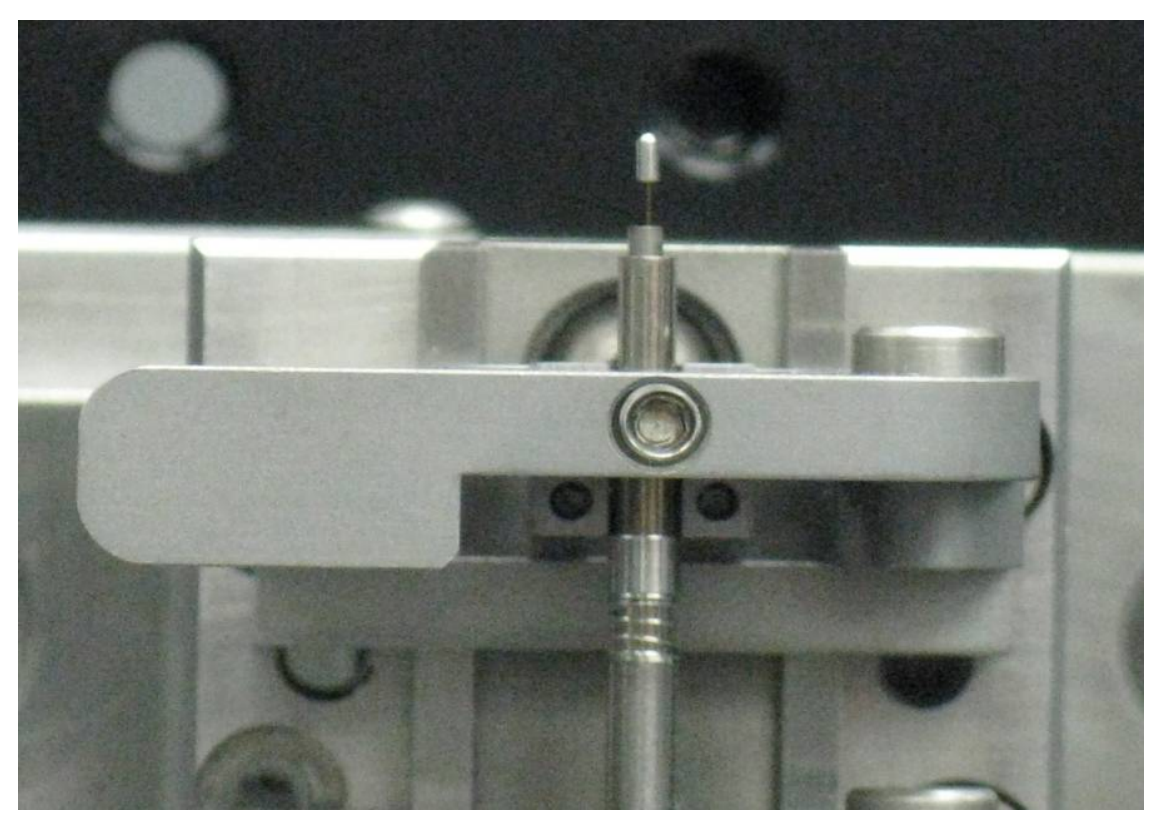

Figure 72. PTOA Sensor tip Alignment Fixture (Close-up) 
Figure 73 shows the bonding material being added to the PTOA sensor tip. The toothpick gives a good indication of the size of this assembly.

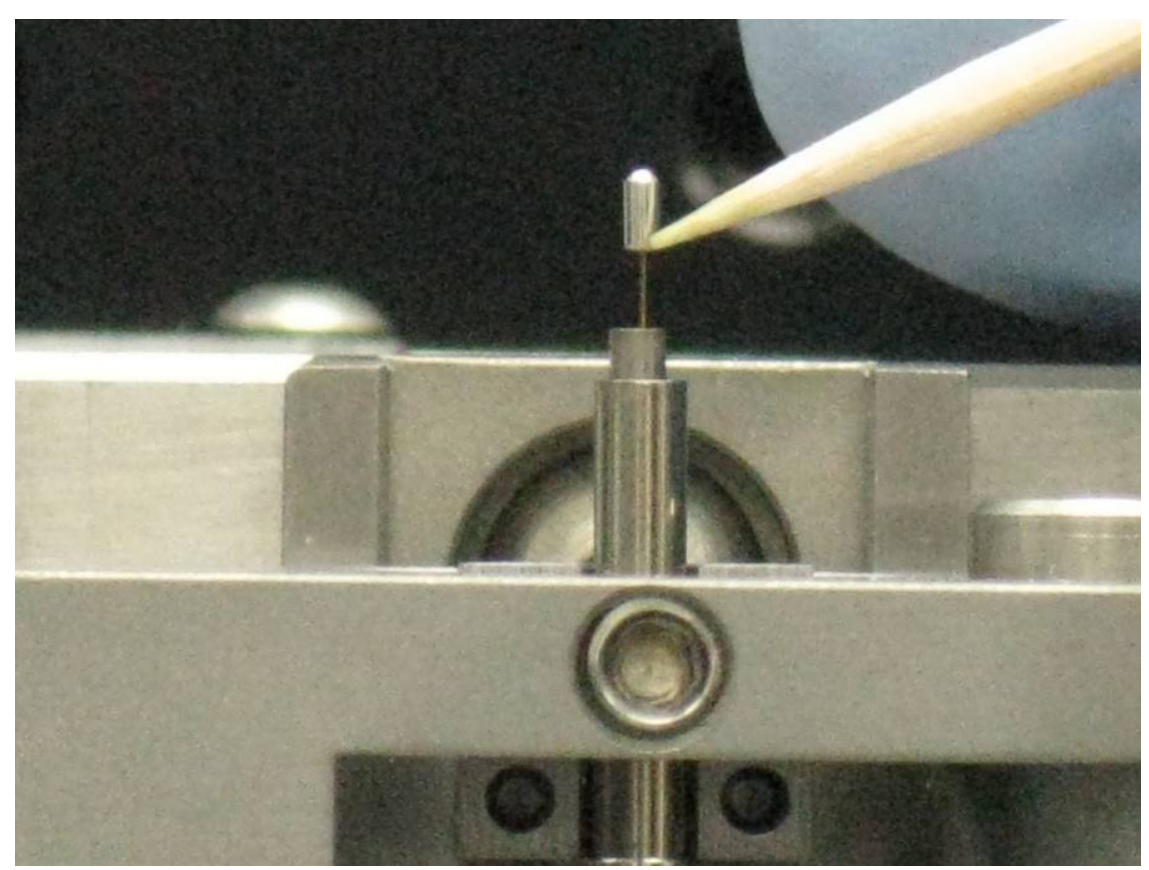

Figure 73. PTOA Sensor tip Being Bonded (Close-up) 
Figure 74 also shows the collar in place around the PTOA sensor tip.

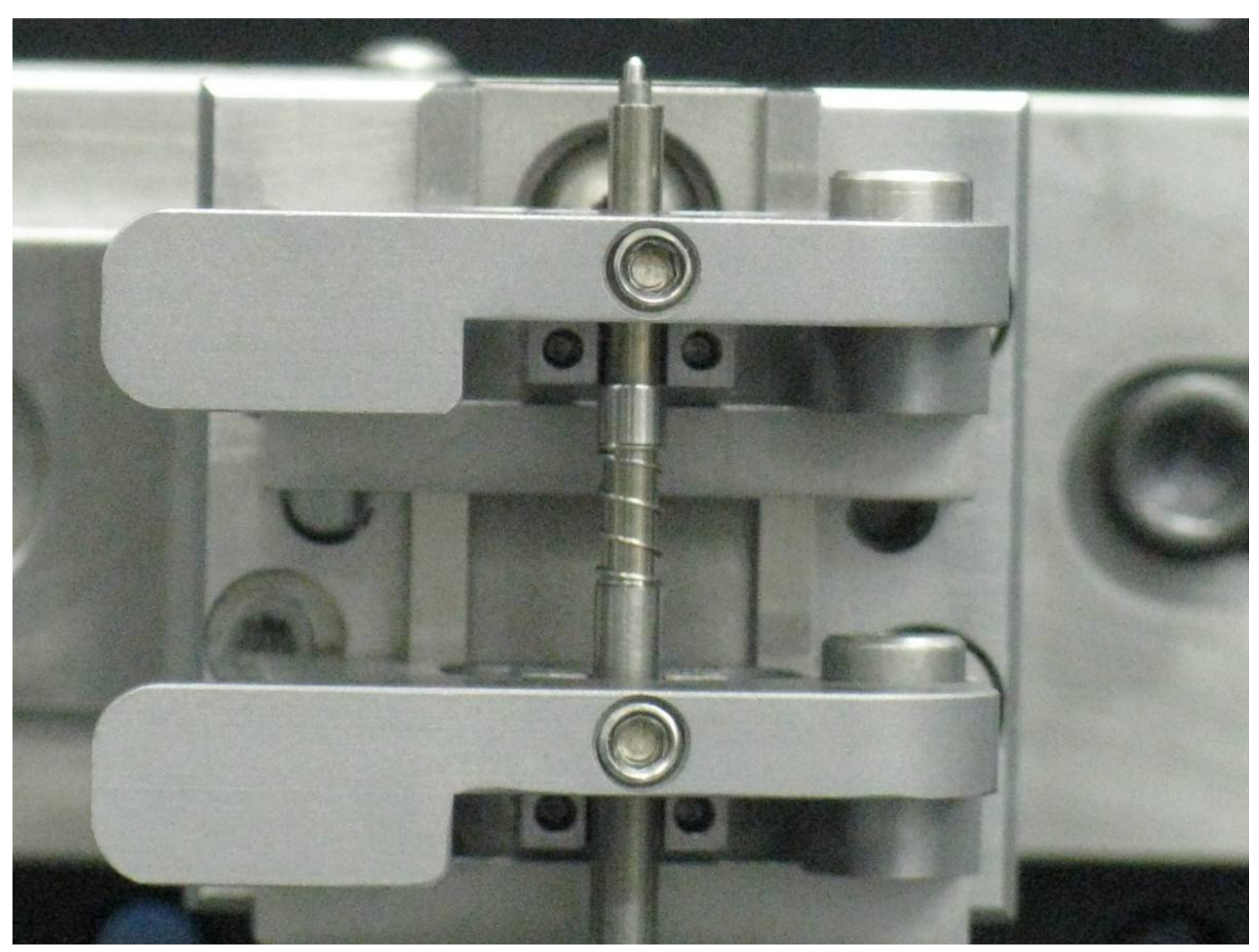

Figure 74. PTOA Sensor tip Bonded in Place (Close-up)

The following self-check test was performed to verify the assembled PTOA sensors function properly. To establish a baseline measurement, a fiber coupled VCSEL was mated directly to a fiber coupled photodetector with bare fiber Bullet adaptors. The VCSEL was driven with a 2 volt amplitude single 10 microsecond pulse from the pulse generator. The detector was measured on the o-scope with a $50 \mathrm{ohm}$ load. The initial pulse amplitude shown on the o-scope was $71 \mathrm{mV}$. The VCSEL and detector were each connected to one leg of the 50/50 coupler as inputs. The output of the coupler was connected to the sensor and the VCSEL pulse travels down one leg of the coupler and $50 \%$ of the signal is bounced off of the sensor mirror. The reflected signal then returns back to the coupler and $50 \%$ of that signal is directed to the detector. Assuming an average of $90 \%$ reflection from the sensor mirror and ignoring insertion losses, the maximum amplitude of the return signal would be approximately $16 \mathrm{mV}$. The actual measured returns varied from $8.2 \mathrm{mV}$ to $12.5 \mathrm{mV}$. Three measurements were taken to verify proper operation in the static, compressed and relaxed states. It should be noted that the sensors were only compressed until a noticeable drop in reflection was observed. This drop in reflection is due to attenuation caused by stressing the fiber with a micro bend. Stressing the fiber beyond this condition dramatically increases the chance of breaking the fiber and ruining the sensor. 
Figure 75 shows a block diagram of the PTOA self-check test set-up configuration.

The test set-up consisted of the following equipment in the following configuration:

Agilent Function Generator

Tektronix O-scope

-PDLD fiber pigtailed VCSEL

$\square$ PDLD fiber pigtailed photo detector

Bullet bare fiber adaptors (2)

Bullet $2.5 \mathrm{~mm}$ to $2.5 \mathrm{~mm}$ split sleeve couplers (3)

-Gould 50/50 coupler

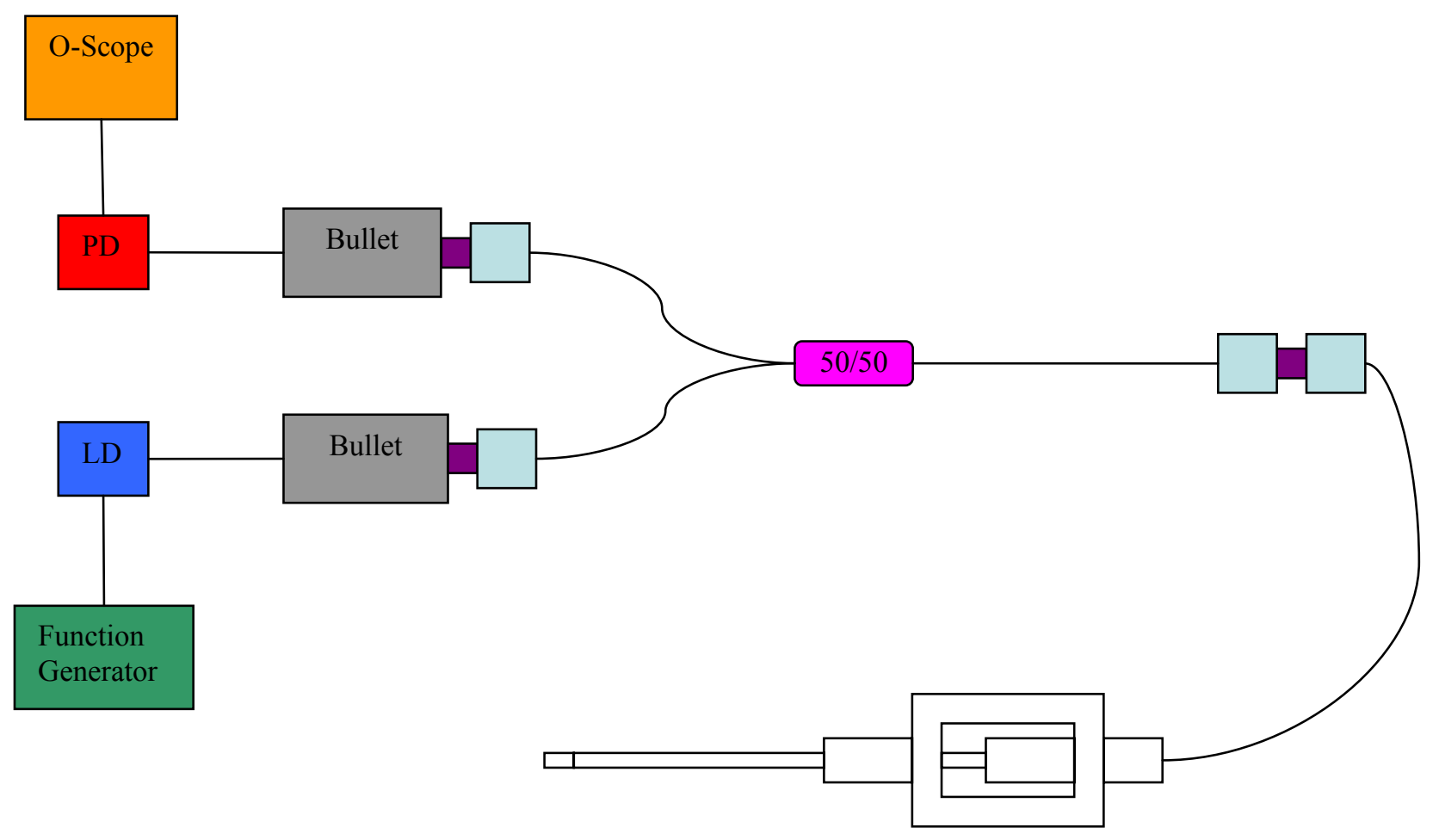

Figure 75. PTOA Self-Check Test set-up Configuration 
Figure 76 shows the actual equipment and set-up used for the PTOA self-check test.

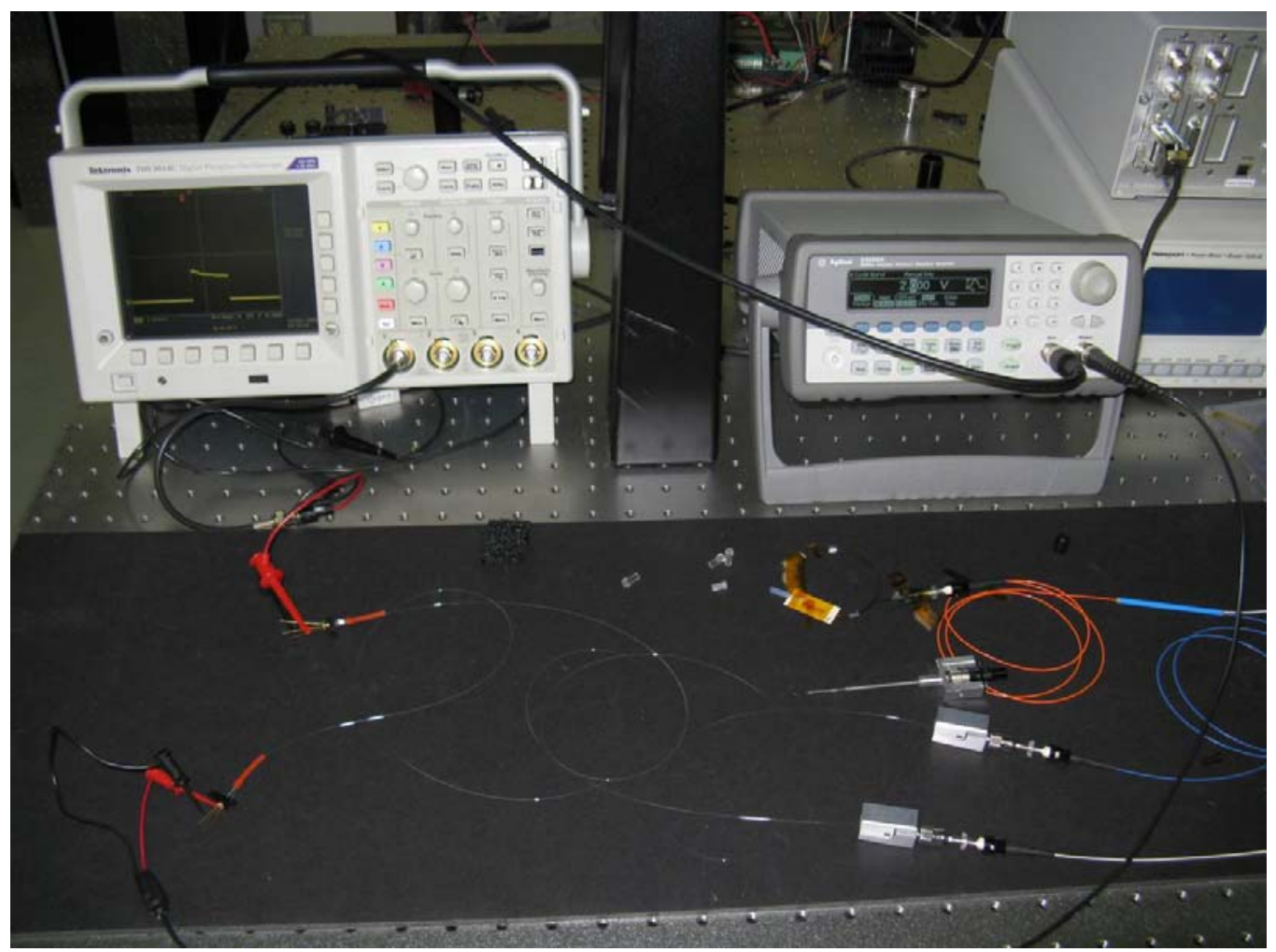

Figure 76. PTOA Self-Check Test set-up 
Table 4 shows the results from the 47 assembled units evaluated on the PTOA self-check test.

\begin{tabular}{|c|c|c|c|}
\hline Unit \# & Initial Reading (mV) & Compressed & Post Comp. \\
\hline 1 & 9.5 & 3 & 9.5 \\
\hline 2 & 9.8 & 8.5 & 10 \\
\hline 3 & 9.3 & 7.4 & 9.2 \\
\hline 4 & 1.7 & $\sim$ & Broken \\
\hline 5 & 10.7 & 8 & 10.5 \\
\hline 6 & 11.2 & 9.8 & 11.1 \\
\hline 7 & 11.4 & 7.9 & 11.5 \\
\hline 8 & 11 & 7.7 & 11 \\
\hline 9 & 9 & $\sim$ & $\sim$ Broken \\
\hline 10 & 11.7 & 10.5 & 11.7 \\
\hline 11 & 10.8 & 9.6 & 10.9 \\
\hline 12 & 8.2 & 6.1 & 8.3 \\
\hline 13 & 11 & 9.7 & 11.1 \\
\hline 14 & 10.2 & 9.2 & 10.3 \\
\hline 15 & 11.2 & 9.4 & 11.3 \\
\hline 16 & 10.8 & 9.9 & 10.7 \\
\hline 17 & 10.1 & 9 & 10 \\
\hline 18 & 11.4 & 10.6 & 11.4 \\
\hline 19 & 11.6 & 10.4 & 11.6 \\
\hline 20 & 10.4 & 8.8 & 10.4 \\
\hline 21 & 11.6 & 10.4 & 11.6 \\
\hline 22 & 12.1 & 9.6 & 11.9 \\
\hline 23 & 11.1 & 9.7 & 11.2 \\
\hline 24 & 12.3 & 10.7 & 12.3 \\
\hline 25 & 10.8 & 7.8 & 11 \\
\hline 26 & 11.7 & 10.9 & 11.9 \\
\hline 27 & 11.9 & 10.9 & 12 \\
\hline 28 & 11.8 & 10.8 & 11.7 \\
\hline 29 & 12.2 & 10.9 & 12.5 \\
\hline 30 & 11.8 & 10.8 & 12 \\
\hline 31 & 11.7 & 10.8 & 11.6 \\
\hline 32 & 11.2 & 10.5 & $\sim$ Broken \\
\hline 33 & 11.1 & 10.6 & 11 \\
\hline 34 & 10.9 & 10.5 & 10.8 \\
\hline 35 & 12.2 & 11.6 & 12.4 \\
\hline 36 & 12.2 & 11.7 & 12.2 \\
\hline 37 & 10.4 & 10 & 10.5 \\
\hline 38 & 12.4 & 11.6 & 12.2 \\
\hline 39 & 9.5 & 9 & 9.4 \\
\hline 40 & 9.9 & 9 & 9.9 \\
\hline 41 & 12.4 & 11.8 & 12.5 \\
\hline 42 & 10.7 & 10.2 & 10.8 \\
\hline 43 & 10.1 & 9.6 & 10.1 \\
\hline 44 & 11.2 & 10.5 & 11.3 \\
\hline 45 & 8.4 & 6.8 & 8.3 \\
\hline 46 & 9.3 & 8 & 9.2 \\
\hline 47 & 11 & $\sim$ & Broken \\
\hline
\end{tabular}

Table 4. PTOA Self-Check Test Data 
Yield loss was around 8.5\%. Units were sent to LANL for testing. LANL verified the PTOA concept was valid with successful explosive testing.

\section{Fiber Optic COTS Sensors}

As part of the site-wide objective of Lean development, and evaluation of existing design solutions, this scope was focused on finding COTS fiber optic sensors for monitoring and evaluating their performance in various configurations. The key areas of focus were temperature, strain and displacement. The two primary advantages of fiber optic sensors over more traditional methods of monitoring are immunity to EMI and the ability to be non-contact. When used in their final application, these fiber sensors will require feed-throughs. Additional scope is focused on evaluation and industrial review of hermetic fiber optic feed-throughs.

\section{Temperature Fiber Optics COTS Sensors}

A target design agency specification was between $-40{ }^{\circ} \mathrm{C}$ and $60{ }^{\circ} \mathrm{C}$. An accuracy of $1{ }^{\circ} \mathrm{C}$ was the primary focus with the realization that future NWC temperature ranges might be requested up to $250^{\circ} \mathrm{C}$. Some applications would require "directional" temperature sensing, requiring the monitoring of an object some fixed distance away. There also is a demand for omni-directional temperature sensing where the temperature of a given environment was desired. Since temperature sensing was one of the first applications of fiber optic sensors, the technology is more mature then most other types of sensors. Eight different types of fiber optic, non-contact sensors were identified and purchased. In addition, two "traditional" piezoelectric sensors were purchased for comparison. Most fiber optic based sensors use Bragg gratings. The types of technologies incorporated in this review include: traditional piezoelectric (both analog and digital, not fiber optic sensors), fluoroptic thermometers, two color photodiodes, infrared thermometer, thermopiles and white-light Interferometric technology. 

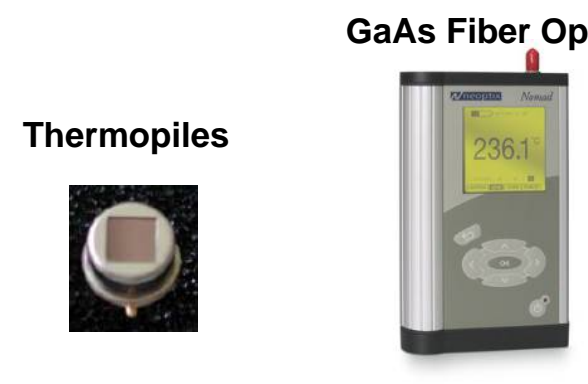

Fiber Optic Pyrometers

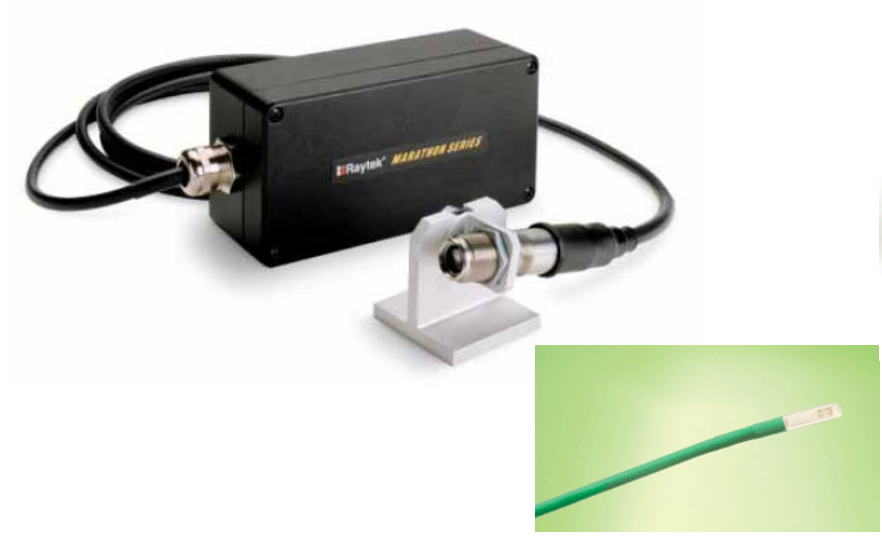

Fluoroptic Fiber Optics

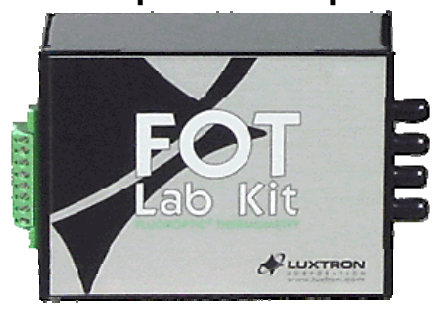

White-Light Interferometric Technology

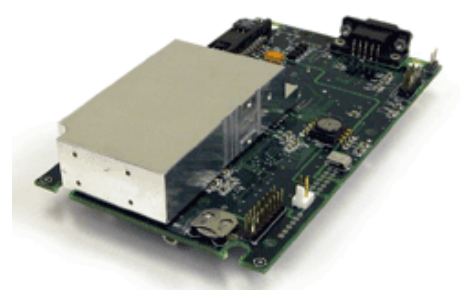

Figure 77. Temperature Sensors

These sensors were evaluated by placing them into a confined metrology well and characterized using maximum temperatures, minimum temperatures, full-range accuracy and resolution, linearity of readings, and noise floor. Based on the vendor-supplied application notes and specifications, almost all sensors being evaluated meet the design agency recommended specifications. The sensors differ in size of the sensor probe/tip; size of the integrator, integration frequency, temperature range, and directional or omni-directional sensing.

Of particular interest are the FISO and OpSens sensors, both use White-Light Interferometric Technology. Both systems allow a single integrator to be a multipurpose device. The sensor can be configured for temperature, strain, displacement, reflective index and pressure. Both companies sell single channel and multiple channel integrators.

All fiber sensors for this test, were bundled together and inserted into a metal cylinder with a hole just large enough to accommodate the sensors. The metal cylinder was then inserted into the secondary standard well. No one sensor appeared any better than the others. 
A comparison of temperature readouts is shown in Figure 78.

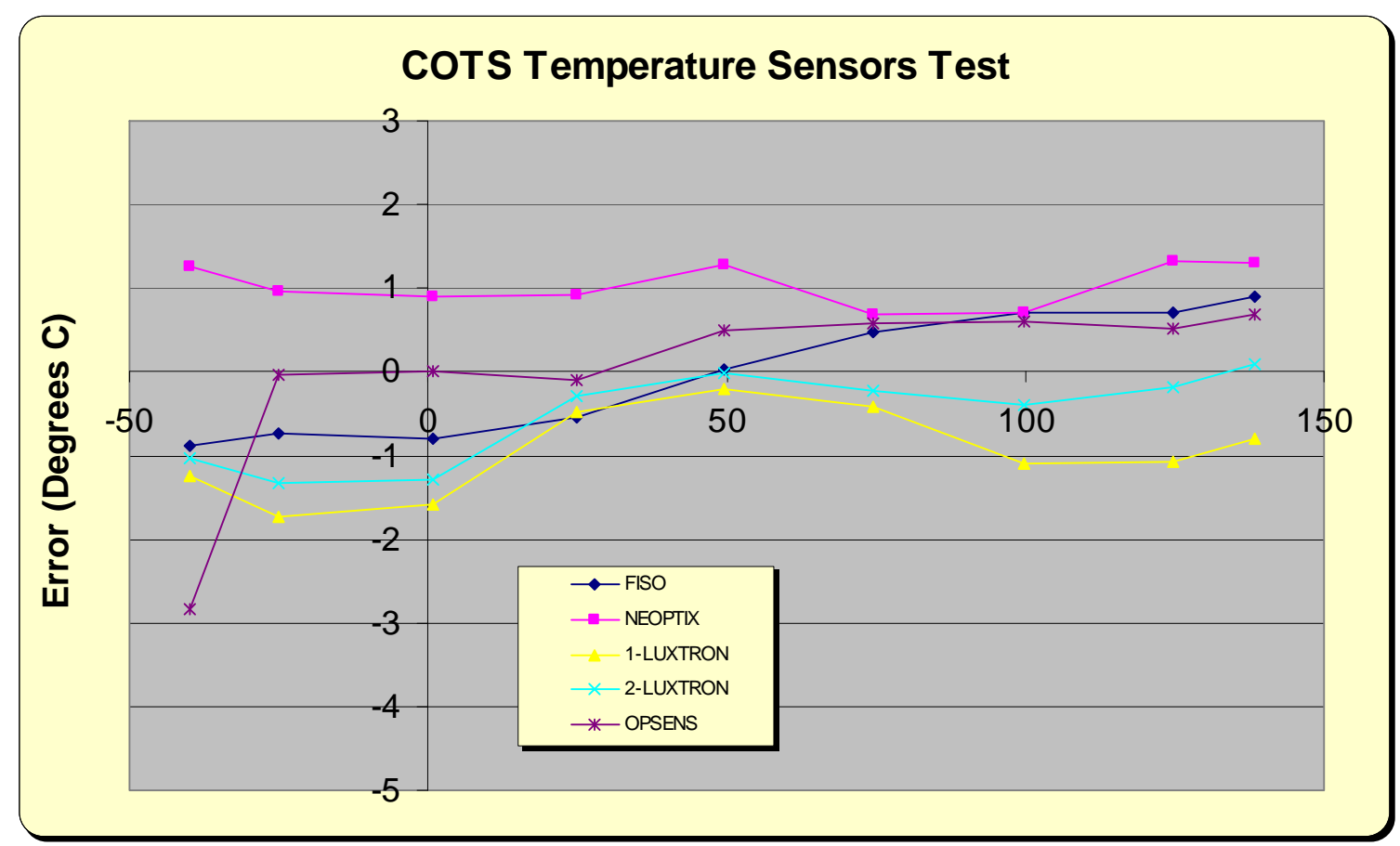

Figure 78. -40 to $+140{ }^{\circ} \mathrm{C}$ results for the FISO, Neoptix, Luxtron, and OpSens Temperature sensors. Note: The $-40^{\circ} \mathrm{C}$ Point for the Opsens Instrument was out of Vendors Specified Range.

\section{Strain Fiber Optics COTS Sensors}

A vendor survey resulted in no commercial non-contact-based strain sensors. There are white papers and patents on approaches which could be taken, but nothing has materialized to this point. The design agencies desired specifications were to find a strain sensor with a $+/-1000$ microstrain range with a +/- 5 microstrain accuracy. KCP has a LUNA Optical Backscattering Reflectometer which uses optical time-domain reflectometry (OTDR) technology to calculate reflections of pulses down a fiber optic cable to either strain measurements or temperature measurements. The resolution and accuracy on single-mode fiber is promising but any measurements on a multimode fiber optic result in unrealistic and incorrect data. The integrator for this unit is quite large with minimum ability to shrink the technology smaller. 

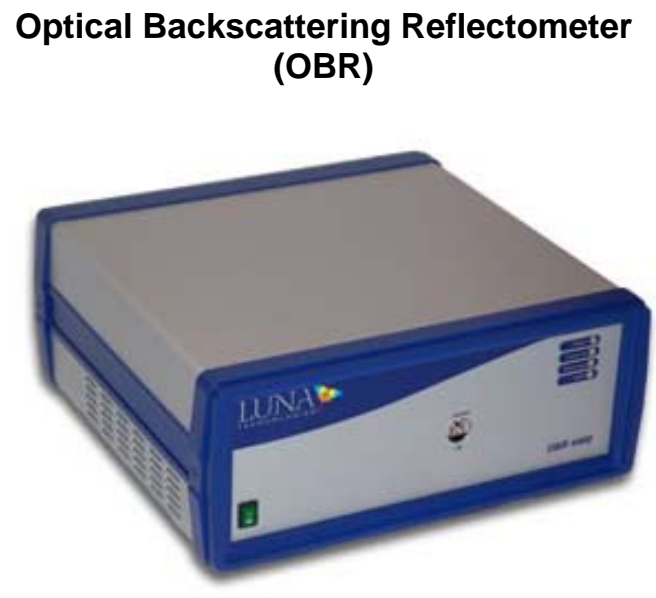

\author{
OpSens/FISO \\ Displacement Sensors
}

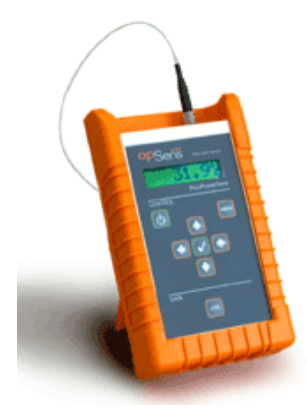

Figure 79. Strain Sensors

Both OpSens and FISO offer contact-based fiber optic strain sensors. Caution is needed to measure actual strain applied as opposed to creep. This risk has been mitigated by holding the sensor tip in place using lead-based solder points, which have been documented not to creep. Various strains applied to both sensors (FISO and OpSens), will result in a characterization curve for evaluation. Additional testing will be performed as the design agencies suggest specific testing materials to apply the sensor.

\section{Displacement Fiber Optics COTS Sensors}

The displacement/vibration sensors requested by the design agencies were to be non-contact based sensors with a displacement range up to $8 \mathrm{~mm}$. Two vendors were identified who currently sell fiber optic non-contact displacement sensors, PhilTec and Keyence. In addition, FISO and OpSens provide contact fiber optic based sensors. They also will be included in the evaluation as a reference, because they use the same integrator as other sensors being evaluated. The PhilTec sensor works by sending light down a central fiber bundle, allowing it to reflect off the target and the sensor collects the signal using 4 fiber bundles all in a confined jacket. One of the advantages of the PhilTec sensors is the option to have a sharp 90 degree turn at the end of the sensor tip. The Keyence sensor uses two diode-based light sources at different positions and wavelengths with two detectors. The detectors take the difference of the two wavelengths and compute distance from the wavelengths absorbed by each detector and the time of arrival. Previous KCP research has been performed similar to the PhilTec method for non-contact displacement sensors. The performance was similar, but the internal develop would have required more development, packaging and sensor costs then what is commercially already available (PhilTec). The FISO and OpSens sensors are contact-based, but work with the common integrator. The technology behind these two sensors is a thin film Fizeau interferometer which is activated by the moving shaft. This film differentiates a Fabry-Perot cavity which can be detected on the other side of the fiber using white-light Interferometric technology. 


\section{PhilTec Displacement Reflectance Compensated Sensors}

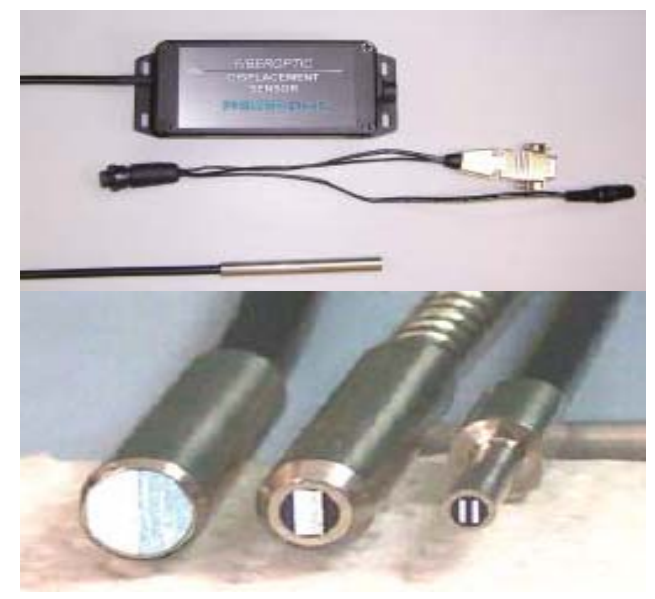

OpSens/FISO Displacement Sensors

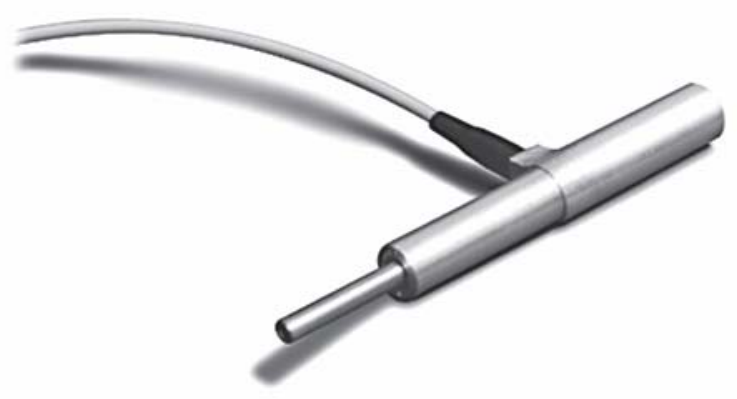

KCP Fiber Optic Bundles Sensors

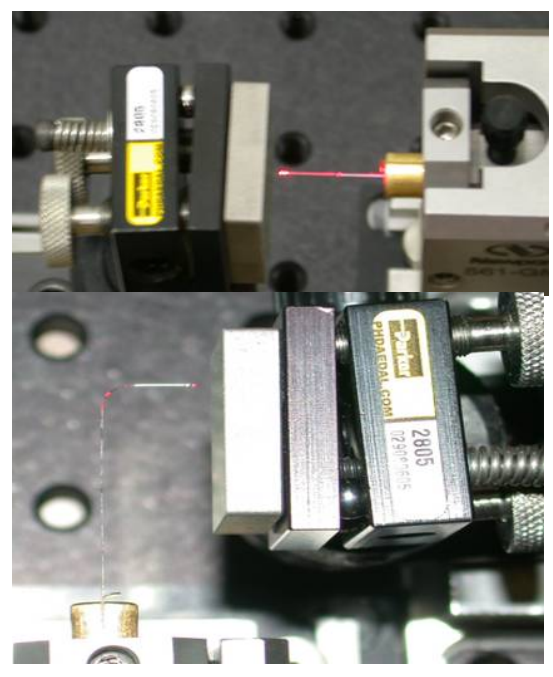

\section{Keyence Displacement Sensors}

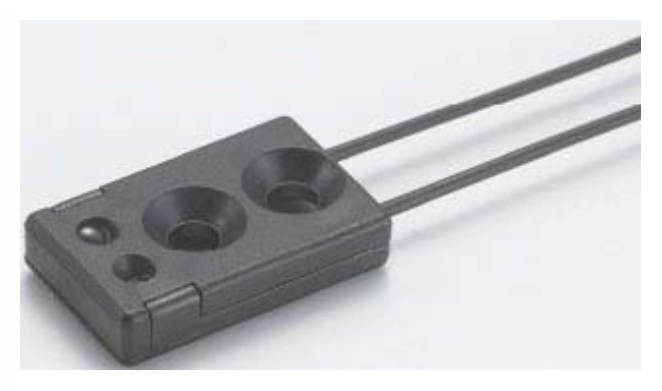

Figure 80. Displacement Sensors

The advantage of all four of these fiber optic sensors (opposed to traditional linear variable differential transformer actuators) is none of these sensors require $\mathrm{AC} /$ driver power and are immune to RFI/EMI. All four of these displacement sensors have 10mm full stroke displacement ranges, with several of the vendors offering shorter and longer stroke lengths. The PhilTec and Keyence sensors have kilohertz integration times where the OpSens/FISO sensors refresh rate is near the 10 hertz range. All four sensors advertise resolution in the micron range, well below the $0.1 \mathrm{~mm}$ suggested specification requested from the design agencies.

To test the sensors, the sensor was mounted on a ThorLabs 3-axis piezoelectric block with a PID feedback and computer control. The resolution of movement of this block is $25 \mathrm{~nm}$. The sensor being evaluated is referenced by a linear variable differential actuator (contact-based, with a $30 \mathrm{~nm}$ resolution) mounted on the same block. A target was placed in front of both sensors and 
the block motion changed the displacement of the sensors. Targets with varying reflectance were used to characterize how the fiber optic based sensors would perform to varying light intensities being reflected off the target. Additional testing will be performed with the sensors placed at various angles to the target and characterized. The initial recommendation, were these sensors to be deployed would be to use a film with a high reflectance (gold mirror has a $99 \%$ reflectance, stainless steel mirror has a $65 \%$ reflectance, silver paint only has a $20 \%$ reflectance) and previously characterized on the target surface.

\title{
Vibration and Shock Testing
}

A total of fourteen different COTS sensors and parts have been selected based on their operational performance to go through shock and vibration testing. These tests simulate the environment encountered in the area. The components chosen for testing are as follows:

\author{
Accu-Glass Ultrahigh Vacuum Conflat Flange Feed-through FO1 \\ Accu-Glass High Vacuum Bolt Style Feed-through BOLT-1 \\ Micron Optics Fiber Fabry-Perot Tunable Filter (FFP-TF) \\ Micron Optics Bragg Grating Fiber (temperature and strain sensor) \\ Avensys Bragg Grating Fiber (temperature and strain sensor) \\ Neoptix Fiber (temperature sensor) \\ LUXTRON Fluoroptic Fiber (temperature sensor) \\ Opsens Fiber (temperature sensor) \\ FISO Fiber (strain and pressure sensor) - 2 \\ Miniature Mechanical Transfer Optical Assembly (MMTOA) - 2 \\ Shock Time of Arrival (STOA) - 2
}

A custom shock and vibration test fixture, seen in Figure 81 below, was designed to hold all parts and sensors in the limited space allowed by the drop-shock test carriage. Each part needed to be placed in such a way that it was easily accessible for operational testing between shock loads. Survivability of the environment was being tested; therefore, the test fixture had to be designed so that the fixture itself would cause no damage to the sensors or parts. Any sharp bends in the fixture where the fiber optic sensors would be housed needed to be rounded out to prevent breakage. Each part had to be secured down to the fixture so that no extra vibration would be seen by the parts other than what was being administered by the test profile. 


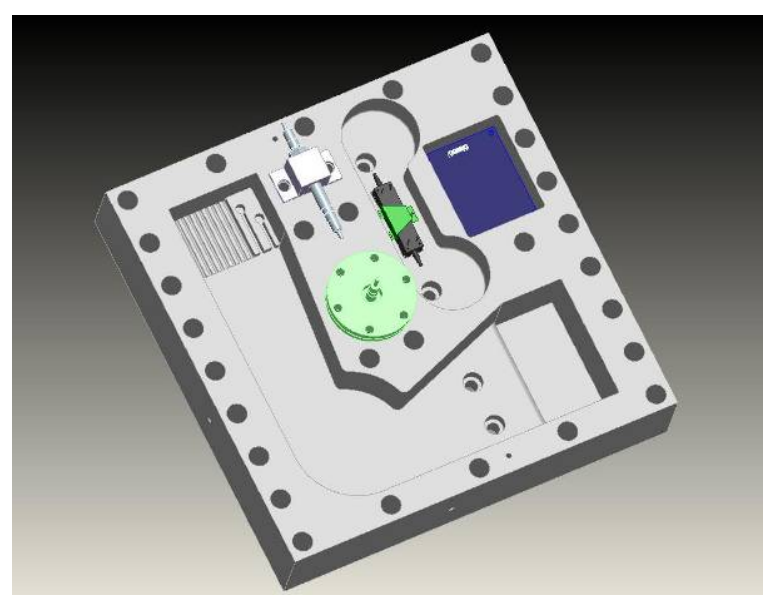

Figure 81. Pro-Engineer Model of Test Fixture

The aluminum test fixture is 13 " long by 13 " wide and takes up the maximum land area allowed by the drop-shock test carriage. The fixture is 2.5 " thick to accommodate the length of the AccuGlass Flange Feed-through at the middle of the fixture and to provide pockets for the various fibers and parts. Numerous bolt holes were placed throughout the fixture to match up with the bolt pattern of the test carriage to securely hold the fixture in place as the shock loads were carried out. Each part was placed in a predetermined area of the fixture to make it easier for multiple people to run survivability tests on the sensors after each load (see Figure 82 below for labeled components). Foam inserts were cut to protect connectors that were not being environmentally tested and to keep optic fibers from coming away from the fixture. Foam pieces were secured in place by Kapton and Duct tape. Two different aluminum brackets were fabricated to securely hold the Accu-Glass Bolt Feed-through and to hold down the Micron Optics Fabry-Perot Filter. The COTS fiber optic sensors and the STOAs were potted into the fixture using Scotch-Weld. 


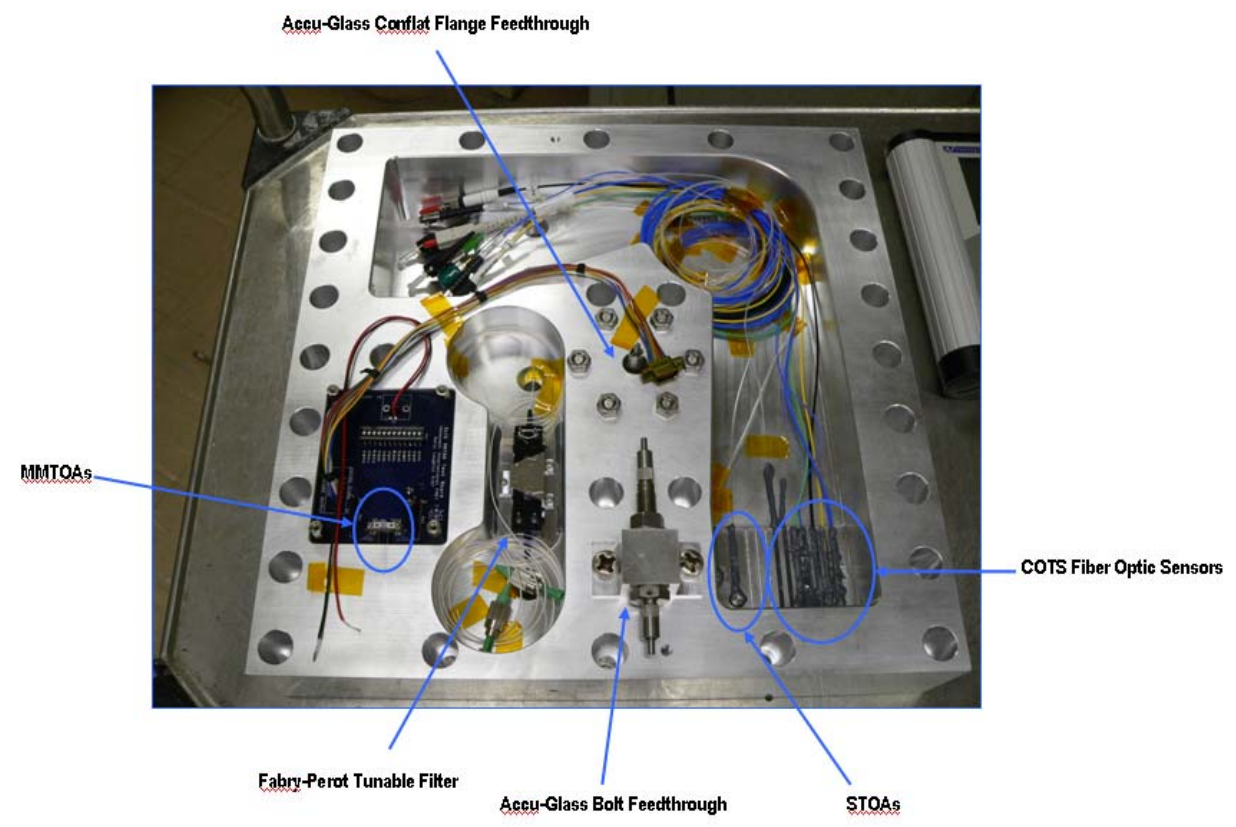

Figure 82. Component Placement within Text Fixture

Testing occurred in the Environmental Lab (E-Lab) and the Kinetics Lab (K-Lab) of KCP. The E-Lab shock-tested the test fixture at $100 \mathrm{~g}, 200 \mathrm{~g}$ and $400 \mathrm{~g}$ in the $+\mathrm{X},+\mathrm{Y}$ and $+\mathrm{Z}$ directions. The $\mathrm{K}-\mathrm{Lab}$ was able to test it even further at $800 \mathrm{~g}, 1500 \mathrm{~g}, 2200 \mathrm{~g}, 3300 \mathrm{~g}, 4000 \mathrm{~g}$ and $5000 \mathrm{~g}$ in the $+\mathrm{X}$, $+\mathrm{Y}$ and $+\mathrm{Z}$ directions. A total of 27 tests were conducted on all of the components. Each part was tested for proper operation after each test.

Five fiber optic sensors were tested by connecting them into their proper transducer/readout and verifying proper operation. The OPSENS PCS Fiber Optic Sensor, the NEOPTIX Fiber Optic Thermometer and the FISO FTI Optical Conditioner with both temperature and pressure sensors continued operating throughout all shock extremes. The Luxtron Industrial Fluoroptic Thermometer developed erratic readings after being cemented into the fixture even before testing began and became further erroneous after $400 \mathrm{~g}$.

The two STOAs were tested by sending a Vcsel signal down the fiber using a splitter and reading a reflectance back in the photodiode detector. They survived up to $5000 \mathrm{~g}$ in the $+\mathrm{X}$ and $+\mathrm{Y}$ directions. However, the Vcsel test source was destroyed and prevented the final test at $5000 \mathrm{~g}$ in the $+\mathrm{Z}$ direction.

The Accu-Glass bulkhead feed-throughs were tested for transmission continuity. The bolt feedthrough was mounted directly on top of the test fixture while the flange feed-through was bolted through the middle of the test fixture. These components were tested by sending a laser signal through each with an Ocean Optics LED light source and comparing their through-put loss to the original signal measured with a Newport power meter. Both SMA attachments became loose in 
their setscrew mountings with the bolt feed-through unit breaking at $800 \mathrm{~g}$ in the $+\mathrm{X}$ direction. The conflate flange unit survived all shock tests.

Two MMTOA assemblies were board mounted then attached with standoffs to the test fixture. These were tested using an Optotest power meter and driven at $3 \mathrm{~V}$ which approximated $18 \mathrm{~mA}$ each. There was an early switch malfunction on the top MMTOA which developed into a failure at $1500 \mathrm{~g}$ in the $+\mathrm{X}$ direction. The bottom MMTOA failed at 5000g in the $+\mathrm{X}$ direction with the top MMTOA losing 2 additional channels of the remaining 11 at $5000 \mathrm{~g}$ in the $+Y$ direction. There was complete failure at the last test of $5000 \mathrm{~g}$ in the $+\mathrm{Z}$ direction.

The fiber optic Bragg filters were tested using a Micron Optics Sensing Interrogator and observing their wavelength spectrum. The smaller fiber was an 8 micron fiber which survived to $3300 \mathrm{~g}$ in the $+Y$ direction, at which time the SMA connector broke off and further testing was discontinued. The larger fiber was a 10 micron fiber which survived all tests.

A Micron Optics Fabry-Perot Tunable Filter was tested using the Micron Optics Sensing Interrogator with SMA connectors and splitter which displayed its characteristic waveform. This survived $4000 \mathrm{~g}$ and failed at $5000 \mathrm{~g}$ in the $+\mathrm{X}$ direction. A complete list of the shock and vibration performance data is shown in Appendix B.

\section{Fiber Optic Connector Systems}

The motivation behind developing the MMTOA concept was to obtain passively aligned fiber optical sources and detector assemblies. The MT connector's alignment pins can be utilized to kinematically locate the VCSEL sources to the fibers on one end of the optical cable and to locate the detectors on the other end. The Dual MMTOA concept seeks to miniaturize the assembly further by utilizing an MT with two rows of optical fibers and a single board with both the sources and detectors.

\section{Miniature MT Optical Assembly}

The existing MMTOA design was found to have a flaw in the ceramic board design. The board was re-designed and new quality boards were purchased for future implementation. The boards arrived and die were flip-chipped onto the boards. An alternate material was looked into through ProtoMold/ProtoCut to potentially replace the metal mounting block on the MMTOA design. The block is currently expensive to machine due to the tight tolerances required. A molded part would be cheaper, but material considerations and even tolerance to cost considerations were examined. It was determined that due to the tolerance restrictions of the vendor, examination of the alternate material would not be pursued at this time. It was found however, that ProtoMold and ProtoCut is a great tool that should be used when possible for fast prototype turnaround. It is an alternative to KCP's Stereolith and 3D printer capabilities with more material options. 


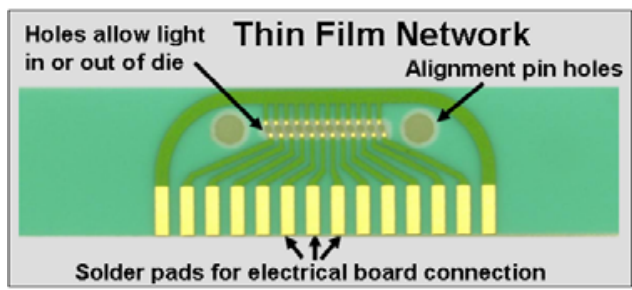

Figure 83. Miniature MT Optical Assembly (MMTOA)

Ceramic substrates were fabricated by KCP in parallel with material being obtained from the outside vendor, UltraSource. Different ceramic substrate designs were utilized in an effort to optimize the process and the ultimate product. Die placement was improved as a result of the failure analysis techniques utilized in addition to improvements due to experienced gained in working with the fabrication processes. Shear testing of the solder joints was performed on various units fabricated onto different types of substrates. Investigations were performed to characterize optical output as a function of die location.
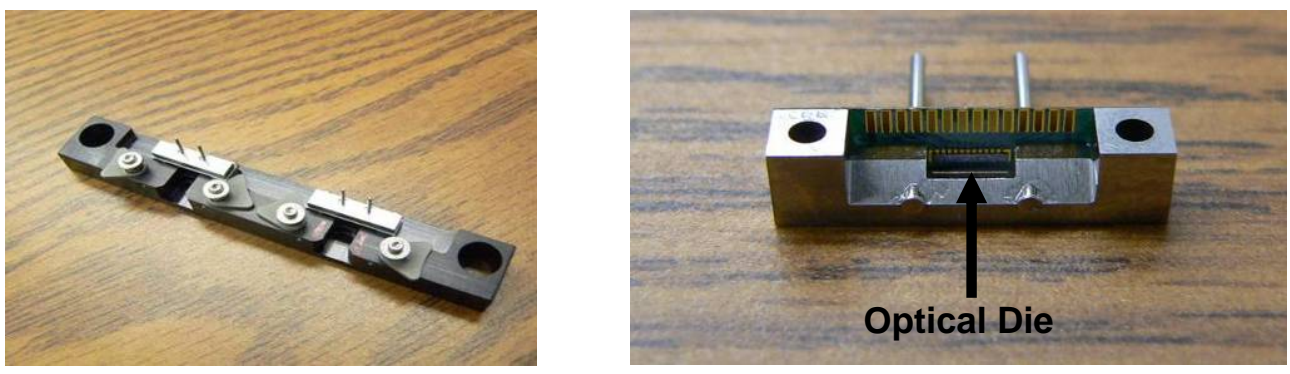

Figure 84. MMTOA Assembly Fixture

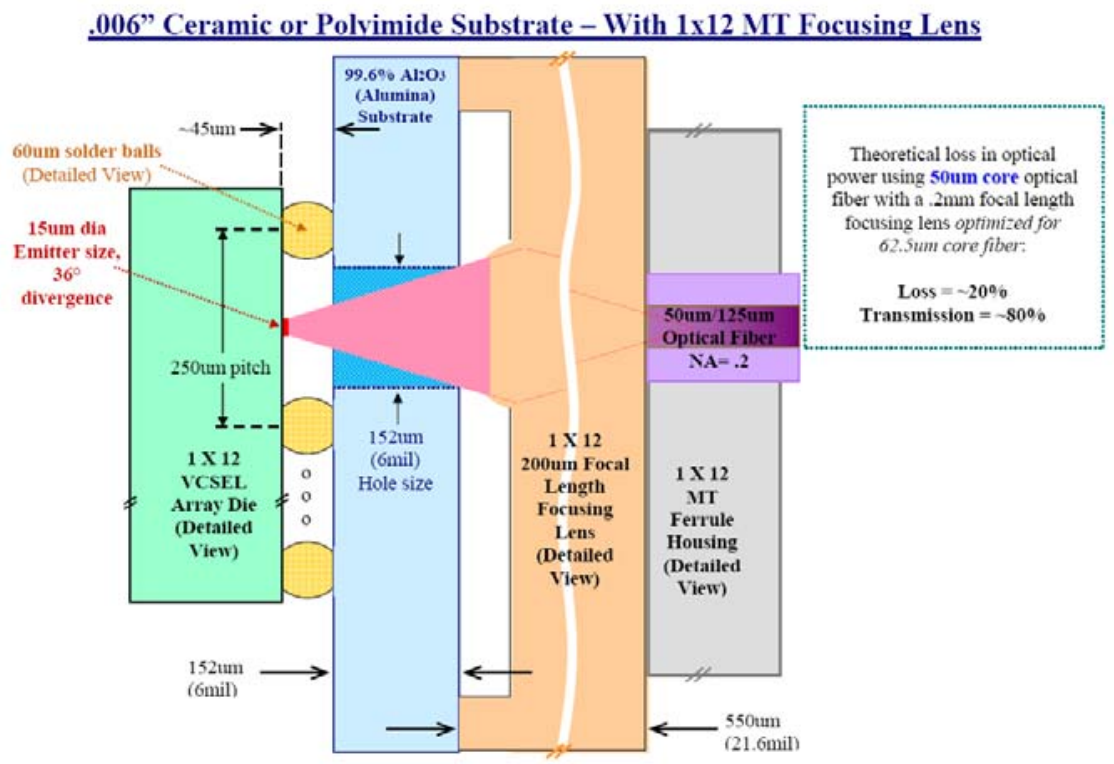

Figure 85. Flip Chip MMTOA Optical Efficiency Calculations 


\section{Dual MMTOA}

The Dual MMTOA was fabricated after being designed in FY07. Boards were received and both die were flip-chipped onto one board. Ambient as well as temperature testing was performed on the parts. The Designed Dual MMTOA parts were laid-out on ceramic substrates utilizing Orcad. The Dual MMTOA design will provide a higher density package containing both VCSEL sources and detectors on the same board (Figure 86). The procurement of a custom focuser lens limited the efficiency of the device, but can be improved upon in the future. The general concept was proven to work and showed the expandability of the MMTOA technology.

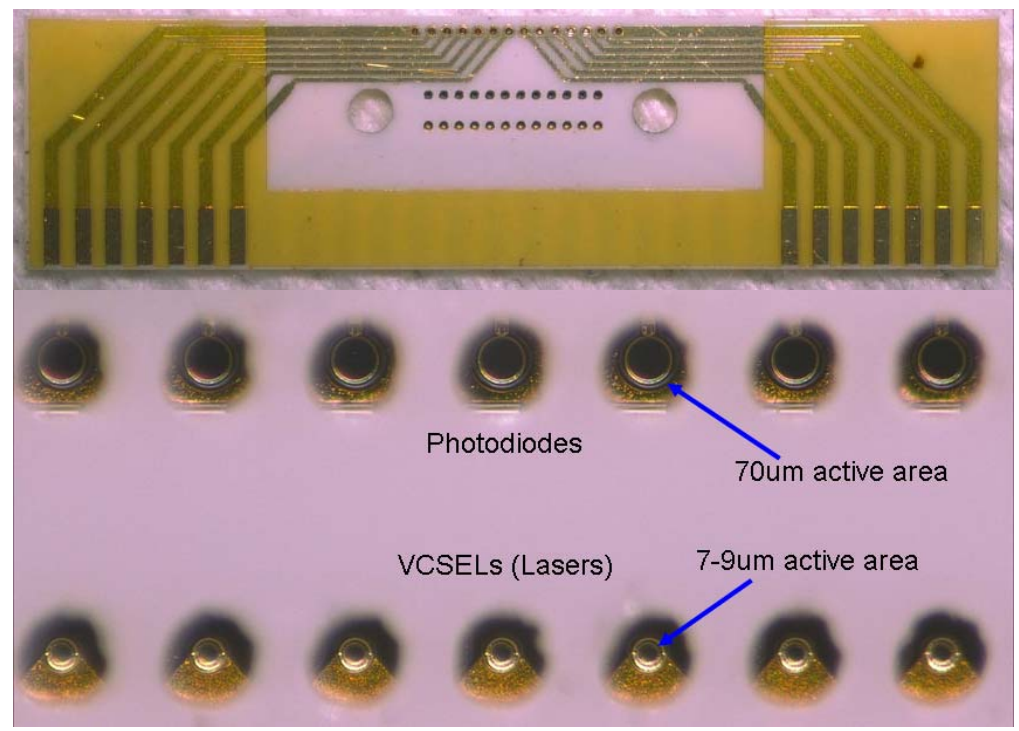

Figure. 86. Dual Miniature MT Optical Assembly (MMTOA)

\section{COTS Right Angle MT}

A COTS right angle MT assembly was created by Fujikura and US CONEC. US CONEC provided $\mathrm{KCP}$ with a sample assembly to test. Industry is having a hard time aligning the VCSEL arrays to the MT array. This matches up very well with the plug and play feature of the MMTOA. The MMTOA solves the alignment issue after it is assembled. A number of ambient tests were conducted with the right angle assembly. More tests were conducted with MT collimator lenses from OMRON Electronics. A sample of the data is shown below. 


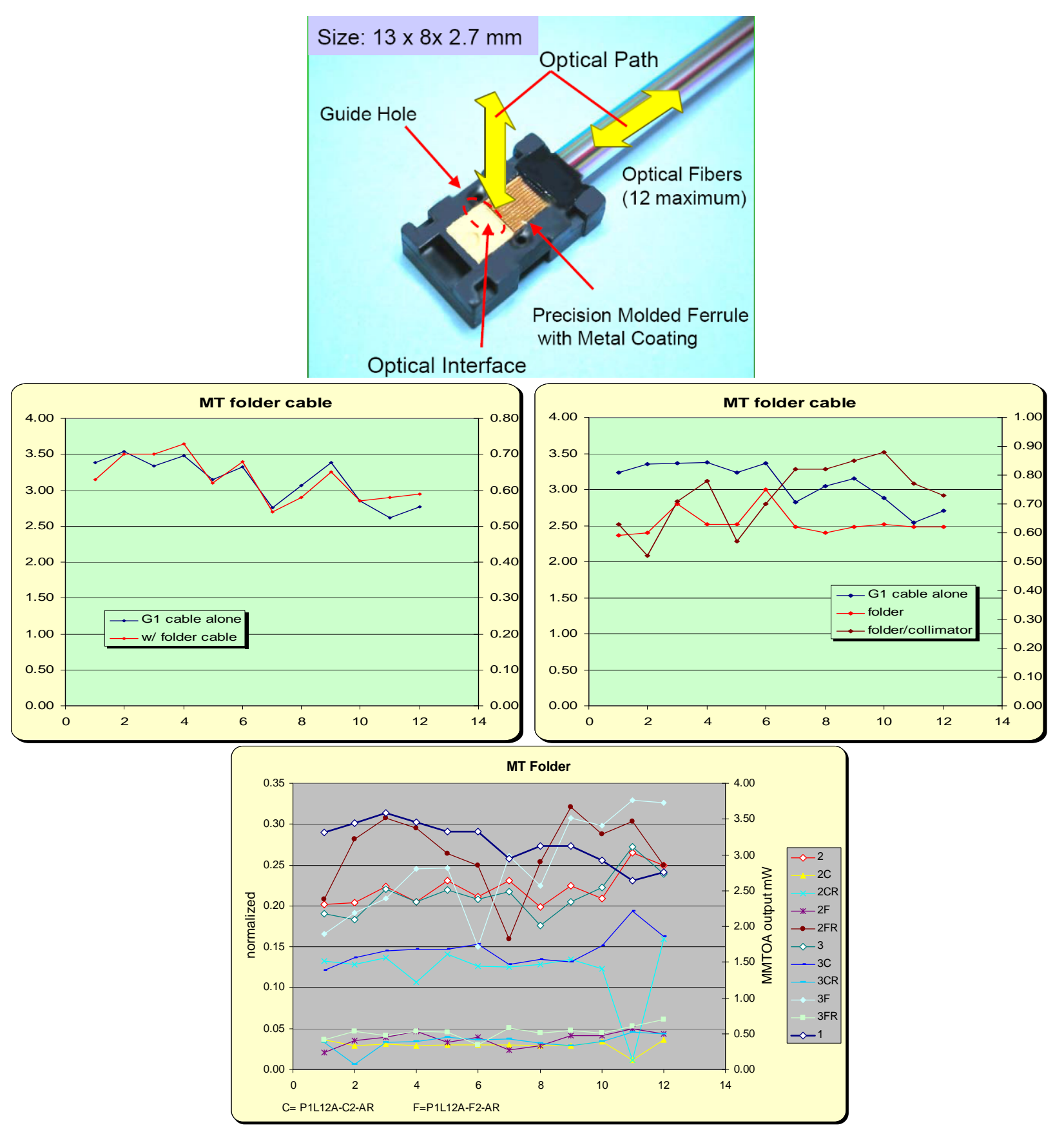

Figure 87. Right Angle MT and Normalized Output 


\section{Accomplishments}

Prototype gas, displacement, and shock sensors were characterized in conjunction with the AESJWG. Benchmarking of commercially available Bragg grating demodulation devices was completed, with a goal of identifying a suitable system that would lend itself to miniaturization and ruggedization. Prototype fiber optic connector systems were developed and characterized. These systems are based on MMTOA and Dual MMTOA packages leveraging the commercial availability of the MT connectors. KCP collaborated with LANL to develop a mutually beneficial guidance document. This report covers the coordinated development of Optical Sensors and requirements. Additionally, this guidance identifies a set of deliverables emphasizing the exchange of information and technology.

Embedded surveillance fiber optic temperature, gas, displacement, and shock sensors were refined for desired applications on future weapon systems. The Optical Backscatter Reflectometer was researched as a method of measuring cracks and micro-strains in HE. Commercial hermetic connectors and seals were evaluated with temperature cycling and helium leak testing. The TDLAS test bed was improved and used to investigate hermetic sealing options for delivering the VCSEL light into a hollow wave guide inside a sealed container. The fiber sensor and hermetic connectors underwent shock and vibration profiles similar to various lifetime weapon environments.

KCP representatives attended the LANL hosted, multi-site Condition Monitoring-Ad Hoc Working Group. Presentations were provided detailing the status of KCP's Embedded Sensors Development projects. KCP participated in breakout sessions in which UK-US Enhanced Collaboration: Condition Monitoring agreements were developed. 


\section{Appendix A}

COTS Hermetic Fiber Optic Connector Specifications 


\begin{tabular}{|c|c|c|c|c|c|c|c|c|c|c|c|c|c|c|c|}
\hline ID & Supplier & Brand Name & Cost & $\begin{array}{c}\text { Connector } \\
\text { Type }\end{array}$ & $\begin{array}{l}\text { Fiber } \\
\text { Profile }\end{array}$ & Mode & $\begin{array}{c}\text { Core } \\
\text { Diameter } \\
\text { (um) }\end{array}$ & $\begin{array}{c}\text { Connection } \\
\text { Material }\end{array}$ & $\begin{array}{c}\mathrm{He} \\
\text { Hermiticity } \\
\text { (cc/min) }\end{array}$ & $\begin{array}{c}\text { Expected } \\
\text { Wavelength } \\
(\mathrm{nm})\end{array}$ & $\begin{array}{l}\text { Insertion } \\
\text { Loss of } \\
\text { Inter- } \\
\text { connects } \\
\text { (dB) } \\
\end{array}$ & $\begin{array}{l}\text { Simple } \\
\text { Feed- } \\
\text { through } \\
\text { or Pigtail }\end{array}$ & $\begin{array}{l}\text { Connector } \\
\text { Dimensions }\end{array}$ & $\begin{array}{l}\text { Possible } \\
\text { Temp } \\
\text { (C) }\end{array}$ & $\begin{array}{c}\text { Fiber\# } \\
\text { Through } \\
\text { Flange } \\
\end{array}$ \\
\hline 1 & $\begin{array}{l}\text { Fiber } \\
\text { Systems } \\
\text { International }\end{array}$ & Amphenol & 0.00 & D38999 & & $\begin{array}{l}\text { Multi- } \\
\text { mode }\end{array}$ & $50 / 125$ & $\begin{array}{l}\text { Electroless } \\
\text { Nickel and } \\
\text { Olive Drab } \\
\text { Cadmium }\end{array}$ & $1.00 \mathrm{E}-07$ & & & $\begin{array}{l}\text { Feed- } \\
\text { through }\end{array}$ & & & Single \\
\hline 2 & $\begin{array}{l}\text { Fiber } \\
\text { Systems } \\
\text { International }\end{array}$ & Amphenol & 0.00 & D38999 & & $\begin{array}{l}\text { Multi- } \\
\text { mode }\end{array}$ & $62.5 / 125$ & $\begin{array}{l}\text { Electroless } \\
\text { Nickel and } \\
\text { Olive Drab } \\
\text { Cadmium }\end{array}$ & $1.00 \mathrm{E}-07$ & & 0 & $\begin{array}{l}\text { Feed- } \\
\text { through }\end{array}$ & & & Single \\
\hline 3 & $\begin{array}{l}\text { Fiber } \\
\text { Systems } \\
\text { International }\end{array}$ & Amphenol & 0.00 & CF & & $\begin{array}{l}\text { Multi- } \\
\text { mode }\end{array}$ & $50 / 125$ & $\begin{array}{l}\text { Electroless } \\
\text { Nickel and } \\
\text { Olive Drab } \\
\text { Cadmium }\end{array}$ & $1.00 \mathrm{E}-07$ & & 0 & $\begin{array}{l}\text { Feed- } \\
\text { through }\end{array}$ & & & Single \\
\hline 4 & $\begin{array}{l}\text { Fiber } \\
\text { Systems } \\
\text { International }\end{array}$ & Amphenol & 0.00 & CF & & $\begin{array}{l}\text { Multi- } \\
\text { mode }\end{array}$ & $62.5 / 125$ & $\begin{array}{l}\text { Electroless } \\
\text { Nickel and } \\
\text { Olive Drab } \\
\text { Cadmium }\end{array}$ & $1.00 \mathrm{E}-07$ & & 0 & $\begin{array}{l}\text { Feed- } \\
\text { through }\end{array}$ & & & Single \\
\hline 5 & $\begin{array}{l}\text { Fiberguide } \\
\text { Industries }\end{array}$ & $\begin{array}{l}\text { FO Feed- } \\
\text { Through } \\
\text { Series }\end{array}$ & 0.00 & SMA & & $\begin{array}{l}\text { Multi- } \\
\text { mode }\end{array}$ & $\begin{array}{l}50 \text { to } \\
1500\end{array}$ & $\begin{array}{l}\text { Stainless } \\
\text { Steel }\end{array}$ & $1.00 \mathrm{E}-07$ & VI/NIR & $\begin{array}{l}-0.8 \mathrm{~dB} \text { to }- \\
2.0 \mathrm{~dB}\end{array}$ & Pigtail & $\begin{array}{l}2 "(L) x \\
0.375 "(D)\end{array}$ & 250 & Single \\
\hline 6 & $\begin{array}{l}\text { Fiberguide } \\
\text { Industries }\end{array}$ & $\begin{array}{l}\text { FO Feed- } \\
\text { Through } \\
\text { Series }\end{array}$ & 0.00 & ST & & $\begin{array}{l}\text { Multi- } \\
\text { mode }\end{array}$ & $\begin{array}{l}50 \text { to } \\
1500\end{array}$ & $\begin{array}{l}\text { Stainless } \\
\text { Steel }\end{array}$ & $1.00 \mathrm{E}-07$ & VI/NIR & $\begin{array}{l}-0.8 \mathrm{~dB} \text { to }- \\
2.0 \mathrm{~dB}\end{array}$ & Pigtail & $\begin{array}{l}2 "(L) x \\
0.375^{\prime \prime}(D)\end{array}$ & 250 & Single \\
\hline 7 & $\begin{array}{l}\text { Fiberguide } \\
\text { Industries }\end{array}$ & $\begin{array}{l}\text { FO Feed- } \\
\text { Through } \\
\text { Series }\end{array}$ & 0.00 & FC & & $\begin{array}{l}\text { Multi- } \\
\text { mode }\end{array}$ & $\begin{array}{l}50 \text { to } \\
1500\end{array}$ & $\begin{array}{l}\text { Stainless } \\
\text { Steel }\end{array}$ & $1.00 \mathrm{E}-07$ & VI/NIR & $\begin{array}{l}-0.8 \mathrm{~dB} \text { to }- \\
2.0 \mathrm{~dB}\end{array}$ & Pigtail & $\begin{array}{l}2 "(L) x \\
0.375^{\prime \prime}(D)\end{array}$ & 250 & Single \\
\hline 8 & $\begin{array}{l}\text { Fiberguide } \\
\text { Industries }\end{array}$ & $\begin{array}{l}\text { FO Feed- } \\
\text { Through } \\
\text { Series }\end{array}$ & 0.00 & Ferrule & & $\begin{array}{l}\text { Multi- } \\
\text { mode }\end{array}$ & $\begin{array}{l}50 \text { to } \\
1500\end{array}$ & $\begin{array}{l}\text { Stainless } \\
\text { Steel }\end{array}$ & $1.00 \mathrm{E}-07$ & VI/NIR & $\begin{array}{l}-0.8 \mathrm{~dB} \text { to }- \\
2.0 \mathrm{~dB}\end{array}$ & Pigtail & $\begin{array}{l}2 "(L) x \\
0.375 "(D)\end{array}$ & 250 & Single \\
\hline 9 & $\begin{array}{l}\text { Ocean } \\
\text { Optics }\end{array}$ & $\begin{array}{l}\text { Vacuum } \\
\text { Feed- } \\
\text { Throughs }\end{array}$ & 314.00 & SMA & $\begin{array}{l}\text { Step- } \\
\text { Index }\end{array}$ & $\begin{array}{l}\text { Multi- } \\
\text { mode }\end{array}$ & 200 & $\begin{array}{l}\text { Metal-to- } \\
\text { Glass }\end{array}$ & $1.00 \mathrm{E}-10$ & & 0 & $\begin{array}{l}\text { Feed- } \\
\text { through }\end{array}$ & & 350 & Single \\
\hline 10 & $\begin{array}{l}\text { Ocean } \\
\text { Optics }\end{array}$ & $\begin{array}{l}\text { Vacuum } \\
\text { Feed- } \\
\text { Throughs }\end{array}$ & 314.00 & SMA & $\begin{array}{l}\text { Step- } \\
\text { Index }\end{array}$ & $\begin{array}{l}\text { Multi- } \\
\text { mode }\end{array}$ & 400 & $\begin{array}{l}\text { Metal-to- } \\
\text { Glass }\end{array}$ & $1.00 \mathrm{E}-10$ & & 0 & $\begin{array}{l}\text { Feed- } \\
\text { through }\end{array}$ & & 350 & Single \\
\hline 11 & $\begin{array}{l}\text { Ocean } \\
\text { Optics }\end{array}$ & $\begin{array}{l}\text { Vacuum } \\
\text { Feed- } \\
\text { Throughs }\end{array}$ & 314.00 & SMA & $\begin{array}{l}\text { Step- } \\
\text { Index }\end{array}$ & $\begin{array}{l}\text { Multi- } \\
\text { mode }\end{array}$ & 600 & $\begin{array}{l}\text { Metal-to- } \\
\text { Glass }\end{array}$ & $1.00 \mathrm{E}-10$ & UV or VIS & 0 & $\begin{array}{l}\text { Feed- } \\
\text { through }\end{array}$ & & 350 & Single \\
\hline 12 & $\begin{array}{l}\text { Ocean } \\
\text { Optics }\end{array}$ & $\begin{array}{l}\text { Vacuum } \\
\text { Feed- } \\
\text { Throughs }\end{array}$ & 314.00 & SMA & $\begin{array}{l}\text { Step- } \\
\text { Index }\end{array}$ & $\begin{array}{l}\text { Multi- } \\
\text { mode }\end{array}$ & 1000 & $\begin{array}{l}\text { Metal-to- } \\
\text { Glass }\end{array}$ & 1.00E-10 & & 0 & $\begin{array}{l}\text { Feed- } \\
\text { through }\end{array}$ & & 350 & Single \\
\hline
\end{tabular}




\begin{tabular}{|c|c|c|c|c|c|c|c|c|c|c|c|c|c|c|c|}
\hline ID & Supplier & Brand Name & Cost & $\begin{array}{c}\text { Connector } \\
\text { Type }\end{array}$ & $\begin{array}{l}\text { Fiber } \\
\text { Profile }\end{array}$ & Mode & $\begin{array}{l}\text { Core } \\
\text { Diameter } \\
\text { (um) }\end{array}$ & $\begin{array}{c}\text { Connection } \\
\text { Material }\end{array}$ & $\begin{array}{c}\mathrm{He} \\
\text { Hermiticity } \\
\text { (cc/min) }\end{array}$ & $\begin{array}{l}\text { Expected } \\
\text { Wavelength } \\
(\mathrm{nm})\end{array}$ & $\begin{array}{l}\text { Insertion } \\
\text { Loss of } \\
\text { Inter- } \\
\text { connects } \\
\text { (dB) }\end{array}$ & $\begin{array}{l}\text { Simple } \\
\text { Feed- } \\
\text { through } \\
\text { or Pigtail }\end{array}$ & $\begin{array}{l}\text { Connector } \\
\text { Dimensions }\end{array}$ & $\begin{array}{l}\text { Possible } \\
\text { Temp } \\
\text { (C) }\end{array}$ & $\begin{array}{l}\text { Fiber\# } \\
\text { Through } \\
\text { Flange }\end{array}$ \\
\hline 13 & $\begin{array}{l}\text { Ocean } \\
\text { Optics }\end{array}$ & $\begin{array}{l}\text { Vacuum } \\
\text { Feed- } \\
\text { Throughs } \\
\text { with } \\
\text { Standard } \\
\text { Flanges }\end{array}$ & 293.00 & SMA & $\begin{array}{l}\text { Step- } \\
\text { Index }\end{array}$ & $\begin{array}{l}\text { Multi- } \\
\text { mode }\end{array}$ & 200 & $\begin{array}{l}\text { Stainless } \\
\text { Steel/Glass } \\
\text { Bonding }\end{array}$ & $1.00 \mathrm{E}-10$ & UV or VIS & $1-1$ & $\begin{array}{l}\text { Feed- } \\
\text { through }\end{array}$ & $\begin{array}{l}1.33 " \text { Con- } \\
\text { Flat } \\
\text { Flanges }\end{array}$ & 350 & Single \\
\hline 14 & $\begin{array}{l}\text { Ocean } \\
\text { Optics }\end{array}$ & $\begin{array}{l}\text { Vacuum } \\
\text { Feed- } \\
\text { Throughs } \\
\text { with } \\
\text { Standard } \\
\text { Flanges }\end{array}$ & 462.00 & SMA & $\begin{array}{l}\text { Step- } \\
\text { Index }\end{array}$ & $\begin{array}{l}\text { Multi- } \\
\text { mode }\end{array}$ & 400 & $\begin{array}{l}\text { Stainless } \\
\text { Steel/Glass } \\
\text { Bonding }\end{array}$ & $1.00 \mathrm{E}-10$ & UV or VIS & 0 & $\begin{array}{l}\text { Feed- } \\
\text { through }\end{array}$ & $\begin{array}{l}1.33 " \text { Con- } \\
\text { Flat } \\
\text { Flanges }\end{array}$ & 350 & Single \\
\hline 15 & $\begin{array}{l}\text { Ocean } \\
\text { Optics }\end{array}$ & $\begin{array}{l}\text { Vacuum } \\
\text { Feed- } \\
\text { Throughs } \\
\text { with } \\
\text { Standard } \\
\text { Flanges }\end{array}$ & 473.00 & SMA & $\begin{array}{l}\text { Step- } \\
\text { Index }\end{array}$ & $\begin{array}{l}\text { Multi- } \\
\text { mode }\end{array}$ & 600 & $\begin{array}{l}\text { Stainless } \\
\text { Steel/Glass } \\
\text { Bonding }\end{array}$ & 1.00E-10 & UV or VIS & 0 & $\begin{array}{l}\text { Feed- } \\
\text { through }\end{array}$ & $\begin{array}{l}1.33^{\prime \prime} \text { Con- } \\
\text { Flat } \\
\text { Flanges }\end{array}$ & 350 & Single \\
\hline 16 & $\begin{array}{l}\text { Ocean } \\
\text { Optics }\end{array}$ & $\begin{array}{l}\text { Vacuum } \\
\text { Feed- } \\
\text { Throughs } \\
\text { with } \\
\text { Standard } \\
\text { Flanges }\end{array}$ & 510.00 & SMA & $\begin{array}{l}\text { Step- } \\
\text { Index }\end{array}$ & $\begin{array}{l}\text { Multi- } \\
\text { mode }\end{array}$ & 1000 & $\begin{array}{l}\text { Stainless } \\
\text { Steel/Glass } \\
\text { Bonding }\end{array}$ & 1.00E-10 & UV or VIS & 0 & $\begin{array}{l}\text { Feed- } \\
\text { through }\end{array}$ & $\begin{array}{l}1.33 " \text { Con- } \\
\text { Flat } \\
\text { Flanges }\end{array}$ & 350 & Single \\
\hline 17 & $\begin{array}{l}\text { Ocean } \\
\text { Optics }\end{array}$ & $\begin{array}{l}\text { Vacuum } \\
\text { Feed- } \\
\text { Throughs } \\
\text { with } \\
\text { Standard } \\
\text { Flanges }\end{array}$ & 473.00 & SMA & $\begin{array}{l}\text { Step- } \\
\text { Index }\end{array}$ & $\begin{array}{l}\text { Multi- } \\
\text { mode }\end{array}$ & 200 & $\begin{array}{l}\text { Stainless } \\
\text { Steel/Glass } \\
\text { Bonding }\end{array}$ & $1.00 \mathrm{E}-10$ & UV or VIS & 0 & $\begin{array}{l}\text { Feed- } \\
\text { through }\end{array}$ & $\begin{array}{l}2.75 " \text { Con- } \\
\text { Flat } \\
\text { Flanges }\end{array}$ & 350 & Single \\
\hline 18 & $\begin{array}{l}\text { Ocean } \\
\text { Optics }\end{array}$ & $\begin{array}{l}\text { Vacuum } \\
\text { Feed- } \\
\text { Throughs } \\
\text { with } \\
\text { Standard } \\
\text { Flanges }\end{array}$ & 478.00 & SMA & $\begin{array}{l}\text { Step- } \\
\text { Index }\end{array}$ & $\begin{array}{l}\text { Multi- } \\
\text { mode }\end{array}$ & 400 & $\begin{array}{l}\text { Stainless } \\
\text { Steel/Glass } \\
\text { Bonding }\end{array}$ & $1.00 \mathrm{E}-10$ & UV or VIS & 0 & $\begin{array}{l}\text { Feed- } \\
\text { through }\end{array}$ & $\begin{array}{l}2.75 " \text { Con- } \\
\text { Flat } \\
\text { Flanges }\end{array}$ & 350 & Single \\
\hline 19 & $\begin{array}{l}\text { Ocean } \\
\text { Optics }\end{array}$ & $\begin{array}{l}\text { Vacuum } \\
\text { Feed- } \\
\text { Throughs } \\
\text { with } \\
\text { Standard } \\
\text { Flanges }\end{array}$ & 489.00 & SMA & $\begin{array}{l}\text { Step- } \\
\text { Index }\end{array}$ & $\begin{array}{l}\text { Multi- } \\
\text { mode }\end{array}$ & 600 & $\begin{array}{l}\text { Stainless } \\
\text { Steel/Glass } \\
\text { Bonding }\end{array}$ & $1.00 \mathrm{E}-10$ & UV or VIS & 0 & $\begin{array}{l}\text { Feed- } \\
\text { through }\end{array}$ & $\begin{array}{l}2.75 " \text { Con- } \\
\text { Flat } \\
\text { Flanges }\end{array}$ & 350 & Single \\
\hline 20 & $\begin{array}{l}\text { Ocean } \\
\text { Optics }\end{array}$ & $\begin{array}{l}\text { Vacuum } \\
\text { Feed- } \\
\text { Throughs } \\
\text { with } \\
\text { Standard } \\
\text { Flanges }\end{array}$ & 524.00 & SMA & $\begin{array}{l}\text { Step- } \\
\text { Index }\end{array}$ & $\begin{array}{l}\text { Multi- } \\
\text { mode }\end{array}$ & 1000 & $\begin{array}{l}\text { Metal-to- } \\
\text { Glass }\end{array}$ & $1.00 \mathrm{E}-10$ & UV or VIS & 0 & $\begin{array}{l}\text { Feed- } \\
\text { through }\end{array}$ & $\begin{array}{l}2.75 " \text { Con- } \\
\text { Flat } \\
\text { Flanges }\end{array}$ & 350 & Single \\
\hline
\end{tabular}




\begin{tabular}{|c|c|c|c|c|c|c|c|c|c|c|c|c|c|c|c|}
\hline ID & Supplier & Brand Name & Cost & $\begin{array}{c}\text { Connector } \\
\text { Type }\end{array}$ & $\begin{array}{l}\text { Fiber } \\
\text { Profile }\end{array}$ & Mode & $\begin{array}{l}\text { Core } \\
\text { Diameter } \\
\text { (um) }\end{array}$ & $\begin{array}{c}\text { Connection } \\
\text { Material }\end{array}$ & $\begin{array}{c}\mathrm{He} \\
\text { Hermiticity } \\
\text { (cc/min) }\end{array}$ & $\begin{array}{l}\text { Expected } \\
\text { Wavelength } \\
(\mathrm{nm})\end{array}$ & $\begin{array}{l}\text { Insertion } \\
\text { Loss of } \\
\text { Inter- } \\
\text { connects } \\
\text { (dB) }\end{array}$ & $\begin{array}{l}\text { Simple } \\
\text { Feed- } \\
\text { through } \\
\text { or Pigtail }\end{array}$ & $\begin{array}{l}\text { Connector } \\
\text { Dimensions }\end{array}$ & $\begin{array}{l}\text { Possible } \\
\text { Temp } \\
\text { (C) }\end{array}$ & $\begin{array}{l}\text { Fiber\# } \\
\text { Through } \\
\text { Flange }\end{array}$ \\
\hline 21 & $\begin{array}{l}\text { Ocean } \\
\text { Optics }\end{array}$ & $\begin{array}{l}\text { Vacuum } \\
\text { Feed- } \\
\text { Throughs } \\
\text { with } \\
\text { Standard } \\
\text { Flanges }\end{array}$ & 452.00 & SMA & $\begin{array}{l}\text { Step- } \\
\text { Index }\end{array}$ & $\begin{array}{l}\text { Multi- } \\
\text { mode }\end{array}$ & 200 & $\begin{array}{l}\text { Stainless } \\
\text { Steel/Glass } \\
\text { Bonding }\end{array}$ & $1.00 \mathrm{E}-10$ & UV or VIS & $1-1$ & $\begin{array}{l}\text { Feed- } \\
\text { through }\end{array}$ & $\begin{array}{l}\text { KF16 ISO } \\
\text { Flanges }\end{array}$ & 350 & Single \\
\hline 22 & $\begin{array}{l}\text { Ocean } \\
\text { Optics }\end{array}$ & $\begin{array}{l}\text { Vacuum } \\
\text { Feed- } \\
\text { Throughs } \\
\text { with } \\
\text { Standard } \\
\text { Flanges }\end{array}$ & 457.00 & SMA & $\begin{array}{l}\text { Step- } \\
\text { Index }\end{array}$ & $\begin{array}{l}\text { Multi- } \\
\text { mode }\end{array}$ & 400 & $\begin{array}{l}\text { Stainless } \\
\text { Steel/Glass } \\
\text { Bonding }\end{array}$ & $1.00 \mathrm{E}-10$ & UV or VIS & 0 & $\begin{array}{l}\text { Feed- } \\
\text { through }\end{array}$ & $\begin{array}{l}\text { KF16 ISO } \\
\text { Flanges }\end{array}$ & 350 & Single \\
\hline 23 & $\begin{array}{l}\text { Ocean } \\
\text { Optics }\end{array}$ & $\begin{array}{l}\text { Vacuum } \\
\text { Feed- } \\
\text { Throughs } \\
\text { with } \\
\text { Standard } \\
\text { Flanges }\end{array}$ & 468.00 & SMA & $\begin{array}{l}\text { Step- } \\
\text { Index }\end{array}$ & $\begin{array}{l}\text { Multi- } \\
\text { mode }\end{array}$ & 600 & $\begin{array}{l}\text { Stainless } \\
\text { Steel/Glass } \\
\text { Bonding }\end{array}$ & $1.00 \mathrm{E}-10$ & UV or VIS & 0 & $\begin{array}{l}\text { Feed- } \\
\text { through }\end{array}$ & $\begin{array}{l}\text { KF16 ISO } \\
\text { Flanges }\end{array}$ & 350 & Single \\
\hline 24 & $\begin{array}{l}\text { Ocean } \\
\text { Optics }\end{array}$ & $\begin{array}{l}\text { Vacuum } \\
\text { Feed- } \\
\text { Throughs } \\
\text { with } \\
\text { Standard } \\
\text { Flanges }\end{array}$ & 504.00 & SMA & $\begin{array}{l}\text { Step- } \\
\text { Index }\end{array}$ & $\begin{array}{l}\text { Multi- } \\
\text { mode }\end{array}$ & 1000 & $\begin{array}{l}\text { Stainless } \\
\text { Steel/Glass } \\
\text { Bonding }\end{array}$ & 1.00E-10 & UV or VIS & 0 & $\begin{array}{l}\text { Feed- } \\
\text { through }\end{array}$ & $\begin{array}{l}\text { KF16 ISO } \\
\text { Flanges }\end{array}$ & 350 & Single \\
\hline 25 & $\begin{array}{l}\text { Ocean } \\
\text { Optics }\end{array}$ & $\begin{array}{l}\text { Vacuum } \\
\text { Feed- } \\
\text { Throughs } \\
\text { with } \\
\text { Standard } \\
\text { Flanges }\end{array}$ & 468.00 & SMA & $\begin{array}{l}\text { Step- } \\
\text { Index }\end{array}$ & $\begin{array}{l}\text { Multi- } \\
\text { mode }\end{array}$ & 200 & $\begin{array}{l}\text { Stainless } \\
\text { Steel/Glass } \\
\text { Bonding }\end{array}$ & $1.00 \mathrm{E}-10$ & UV or VIS & 0 & $\begin{array}{l}\text { Feed- } \\
\text { through }\end{array}$ & $\begin{array}{l}\text { KF40 ISO } \\
\text { Flanges }\end{array}$ & 350 & Single \\
\hline 26 & $\begin{array}{l}\text { Ocean } \\
\text { Optics }\end{array}$ & $\begin{array}{l}\text { Vacuum } \\
\text { Feed- } \\
\text { Throughs } \\
\text { with } \\
\text { Standard } \\
\text { Flanges }\end{array}$ & 473.00 & SMA & $\begin{array}{l}\text { Step- } \\
\text { Index }\end{array}$ & $\begin{array}{l}\text { Multi- } \\
\text { mode }\end{array}$ & 400 & $\begin{array}{l}\text { Stainless } \\
\text { Steel/Glass } \\
\text { Bonding }\end{array}$ & $1.00 \mathrm{E}-10$ & UV or VIS & 0 & $\begin{array}{l}\text { Feed- } \\
\text { through }\end{array}$ & $\begin{array}{l}\text { KF40 ISO } \\
\text { Flanges }\end{array}$ & 350 & Single \\
\hline 27 & $\begin{array}{l}\text { Ocean } \\
\text { Optics }\end{array}$ & $\begin{array}{l}\text { Vacuum } \\
\text { Feed- } \\
\text { Throughs } \\
\text { with } \\
\text { Standard } \\
\text { Flanges }\end{array}$ & 483.00 & SMA & $\begin{array}{l}\text { Step- } \\
\text { Index }\end{array}$ & $\begin{array}{l}\text { Multi- } \\
\text { mode }\end{array}$ & 600 & $\begin{array}{l}\text { Stainless } \\
\text { Steel/Glass } \\
\text { Bonding }\end{array}$ & $1.00 \mathrm{E}-10$ & UV or VIS & 0 & $\begin{array}{l}\text { Feed- } \\
\text { through }\end{array}$ & $\begin{array}{l}\text { KF40 ISO } \\
\text { Flanges }\end{array}$ & 350 & Single \\
\hline 28 & $\begin{array}{l}\text { Ocean } \\
\text { Optics }\end{array}$ & $\begin{array}{l}\text { Vacuum } \\
\text { Feed- } \\
\text { Throughs } \\
\text { with } \\
\text { Standard } \\
\text { Flanges }\end{array}$ & 520.00 & SMA & $\begin{array}{l}\text { Step- } \\
\text { Index }\end{array}$ & $\begin{array}{l}\text { Multi- } \\
\text { mode }\end{array}$ & 1000 & $\begin{array}{l}\text { Stainless } \\
\text { Steel/Glass } \\
\text { Bonding }\end{array}$ & $1.00 \mathrm{E}-10$ & UV or VIS & 0 & $\begin{array}{l}\text { Feed- } \\
\text { through }\end{array}$ & $\begin{array}{l}\text { KF40 ISO } \\
\text { Flanges }\end{array}$ & 350 & Single \\
\hline
\end{tabular}




\begin{tabular}{|c|c|c|c|c|c|c|c|c|c|c|c|c|c|c|c|}
\hline ID & Supplier & Brand Name & Cost & $\begin{array}{c}\text { Connector } \\
\text { Type }\end{array}$ & $\begin{array}{l}\text { Fiber } \\
\text { Profile }\end{array}$ & Mode & $\begin{array}{l}\text { Core } \\
\text { Diameter } \\
\text { (um) }\end{array}$ & $\begin{array}{c}\text { Connection } \\
\text { Material }\end{array}$ & $\begin{array}{c}\mathrm{He} \\
\text { Hermiticity } \\
\text { (cc/min) }\end{array}$ & $\begin{array}{l}\text { Expected } \\
\text { Wavelength } \\
(\mathrm{nm})\end{array}$ & $\begin{array}{l}\text { Insertion } \\
\text { Loss of } \\
\text { Inter- } \\
\text { connects } \\
\text { (dB) }\end{array}$ & $\begin{array}{l}\text { Simple } \\
\text { Feed- } \\
\text { through } \\
\text { or Pigtail }\end{array}$ & $\begin{array}{l}\text { Connector } \\
\text { Dimensions }\end{array}$ & $\begin{array}{l}\text { Possible } \\
\text { Temp } \\
\text { (C) }\end{array}$ & $\begin{array}{c}\text { Fiber\# } \\
\text { Through } \\
\text { Flange }\end{array}$ \\
\hline 29 & $\begin{array}{l}\text { Accu-Glass } \\
\text { Products }\end{array}$ & $\begin{array}{l}\text { Vacuum } \\
\text { Feed- } \\
\text { Throughs } \\
\text { with } \\
\text { Standard } \\
\text { Flanges }\end{array}$ & 450.00 & SMA & $\begin{array}{l}\text { Step- } \\
\text { Index }\end{array}$ & $\begin{array}{l}\text { Multi- } \\
\text { mode }\end{array}$ & 200 & $\begin{array}{l}\text { Stainless } \\
\text { Steel/Glass } \\
\text { Bonding }\end{array}$ & $1.00 \mathrm{E}-10$ & UV or VIS & 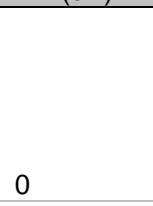 & $\begin{array}{l}\text { Feed- } \\
\text { through }\end{array}$ & $\begin{array}{l}\text { Con-Flat } \\
\text { Flanges }\end{array}$ & 250 & Single \\
\hline 30 & $\begin{array}{l}\text { Accu-Glass } \\
\text { Products }\end{array}$ & $\begin{array}{l}\text { Vacuum } \\
\text { Feed- } \\
\text { Throughs } \\
\text { with } \\
\text { Standard } \\
\text { Flanges }\end{array}$ & 455.00 & SMA & $\begin{array}{l}\text { Step- } \\
\text { Index }\end{array}$ & $\begin{array}{l}\text { Multi- } \\
\text { mode }\end{array}$ & 400 & $\begin{array}{l}\text { Stainless } \\
\text { Steel/Glass } \\
\text { Bonding }\end{array}$ & $1.00 \mathrm{E}-10$ & UV or VIS & 0 & $\begin{array}{l}\text { Feed- } \\
\text { through }\end{array}$ & $\begin{array}{l}\text { Con-Flat } \\
\text { Flanges }\end{array}$ & 250 & Single \\
\hline 31 & $\begin{array}{l}\text { Accu-Glass } \\
\text { Products }\end{array}$ & $\begin{array}{l}\text { Vacuum } \\
\text { Feed- } \\
\text { Throughs } \\
\text { with } \\
\text { Standard } \\
\text { Flanges }\end{array}$ & 465.00 & SMA & $\begin{array}{l}\text { Step- } \\
\text { Index }\end{array}$ & $\begin{array}{l}\text { Multi- } \\
\text { mode }\end{array}$ & 600 & $\begin{array}{l}\text { Stainless } \\
\text { Steel/Glass } \\
\text { Bonding }\end{array}$ & $1.00 \mathrm{E}-10$ & UV or VIS & 0 & $\begin{array}{l}\text { Feed- } \\
\text { through }\end{array}$ & $\begin{array}{l}\text { Con-Flat } \\
\text { Flanges }\end{array}$ & 250 & Single \\
\hline 32 & $\begin{array}{l}\text { Accu-Glass } \\
\text { Products }\end{array}$ & $\begin{array}{l}\text { Vacuum } \\
\text { Feed- } \\
\text { Throughs } \\
\text { with } \\
\text { Standard } \\
\text { Flanges }\end{array}$ & 499.00 & SMA & $\begin{array}{l}\text { Step- } \\
\text { Index }\end{array}$ & $\begin{array}{l}\text { Multi- } \\
\text { mode }\end{array}$ & 1000 & $\begin{array}{l}\text { Stainless } \\
\text { Steel/Glass } \\
\text { Bonding }\end{array}$ & $1.00 \mathrm{E}-10$ & UV or VIS & 0 & $\begin{array}{l}\text { Feed- } \\
\text { through }\end{array}$ & $\begin{array}{l}\text { Con-Flat } \\
\text { Flanges }\end{array}$ & 250 & Single \\
\hline 33 & $\begin{array}{l}\text { Accu-Glass } \\
\text { Products }\end{array}$ & $\begin{array}{l}\text { Vacuum } \\
\text { Feed- } \\
\text { Throughs } \\
\text { with } \\
\text { Standard } \\
\text { Flanges }\end{array}$ & 445.00 & SMA & $\begin{array}{l}\text { Step- } \\
\text { Index }\end{array}$ & $\begin{array}{l}\text { Multi- } \\
\text { mode }\end{array}$ & 200 & $\begin{array}{l}\text { Stainless } \\
\text { Steel/Glass } \\
\text { Bonding }\end{array}$ & $1.00 \mathrm{E}-10$ & UV or VIS & 0 & $\begin{array}{l}\text { Feed- } \\
\text { through }\end{array}$ & $\begin{array}{l}\text { ISO KF } \\
\text { Flanges }\end{array}$ & 250 & Single \\
\hline 34 & $\begin{array}{l}\text { Accu-Glass } \\
\text { Products }\end{array}$ & $\begin{array}{l}\text { Vacuum } \\
\text { Feed- } \\
\text { Throughs } \\
\text { with } \\
\text { Standard } \\
\text { Flanges }\end{array}$ & 450.00 & SMA & $\begin{array}{l}\text { Step- } \\
\text { Index }\end{array}$ & $\begin{array}{l}\text { Multi- } \\
\text { mode }\end{array}$ & 400 & $\begin{array}{l}\text { Stainless } \\
\text { Steel/Glass } \\
\text { Bonding }\end{array}$ & $1.00 \mathrm{E}-10$ & UV or VIS & 0 & $\begin{array}{l}\text { Feed- } \\
\text { through }\end{array}$ & $\begin{array}{l}\text { ISO KF } \\
\text { Flanges }\end{array}$ & 250 & Single \\
\hline 35 & $\begin{array}{l}\text { Accu-Glass } \\
\text { Products }\end{array}$ & $\begin{array}{l}\text { Vacuum } \\
\text { Feed- } \\
\text { Throughs } \\
\text { with } \\
\text { Standard } \\
\text { Flanges }\end{array}$ & 460.00 & SMA & $\begin{array}{l}\text { Step- } \\
\text { Index }\end{array}$ & $\begin{array}{l}\text { Multi- } \\
\text { mode }\end{array}$ & 600 & $\begin{array}{l}\text { Stainless } \\
\text { Steel/Glass } \\
\text { Bonding }\end{array}$ & $1.00 \mathrm{E}-10$ & UV or VIS & 0 & $\begin{array}{l}\text { Feed- } \\
\text { through }\end{array}$ & $\begin{array}{l}\text { ISO KF } \\
\text { Flanges }\end{array}$ & 250 & Single \\
\hline 36 & $\begin{array}{l}\text { Accu-Glass } \\
\text { Products }\end{array}$ & $\begin{array}{l}\text { Vacuum } \\
\text { Feed- } \\
\text { Throughs } \\
\text { with } \\
\text { Standard } \\
\text { Flanges }\end{array}$ & 495.00 & SMA & $\begin{array}{l}\text { Step- } \\
\text { Index }\end{array}$ & $\begin{array}{l}\text { Multi- } \\
\text { mode }\end{array}$ & 1000 & $\begin{array}{l}\text { Stainless } \\
\text { Steel/Glass } \\
\text { Bonding }\end{array}$ & $1.00 \mathrm{E}-10$ & UV or VIS & 0 & $\begin{array}{l}\text { Feed- } \\
\text { through }\end{array}$ & $\begin{array}{l}\text { ISO KF } \\
\text { Flanges }\end{array}$ & 250 & Single \\
\hline
\end{tabular}




\begin{tabular}{|c|c|c|c|c|c|c|c|c|c|c|c|c|c|c|c|}
\hline ID & Supplier & Brand Name & Cost & $\begin{array}{c}\text { Connector } \\
\text { Type }\end{array}$ & $\begin{array}{l}\text { Fiber } \\
\text { Profile }\end{array}$ & Mode & $\begin{array}{c}\text { Core } \\
\text { Diameter } \\
\text { (um) }\end{array}$ & $\begin{array}{c}\text { Connection } \\
\text { Material }\end{array}$ & $\begin{array}{c}\mathrm{He} \\
\text { Hermiticity } \\
\text { (cc/min) }\end{array}$ & $\begin{array}{c}\text { Expected } \\
\text { Wavelength } \\
(\mathrm{nm})\end{array}$ & $\begin{array}{l}\text { Insertion } \\
\text { Loss of } \\
\text { Inter- } \\
\text { connects } \\
\text { (dB) } \\
\end{array}$ & $\begin{array}{l}\text { Simple } \\
\text { Feed- } \\
\text { through } \\
\text { or Pigtail }\end{array}$ & $\begin{array}{l}\text { Connector } \\
\text { Dimensions }\end{array}$ & $\begin{array}{l}\text { Possible } \\
\text { Temp } \\
\text { (C) }\end{array}$ & $\begin{array}{c}\text { Fiber\# } \\
\text { Through } \\
\text { Flange } \\
\end{array}$ \\
\hline 37 & PA\&E & $\begin{array}{l}\text { Kryoflex } \\
\text { Ceramic } \\
\text { Sealing } \\
\text { System }\end{array}$ & 0.00 & $\mathrm{FC} / \mathrm{PC}$ & & $\begin{array}{l}\text { Single- } \\
\text { mode }\end{array}$ & & $\begin{array}{l}\text { Stainless } \\
\text { Steel }\end{array}$ & $1.00 \mathrm{E}-09$ & & $-0.7 \mathrm{~dB}$ & $\begin{array}{l}\text { Feed- } \\
\text { through }\end{array}$ & & 250 & Single \\
\hline 38 & PA\&E & $\begin{array}{l}\text { Kryoflex } \\
\text { Ceramic } \\
\text { Sealing } \\
\text { System }\end{array}$ & 0.00 & $\mathrm{FC} / \mathrm{PC}$ & & $\begin{array}{l}\text { Multi- } \\
\text { mode }\end{array}$ & & $\begin{array}{l}\text { Stainless } \\
\text { Steel }\end{array}$ & 1.00E-09 & & $-0.7 d B$ & $\begin{array}{l}\text { Feed- } \\
\text { through }\end{array}$ & & 250 & Single \\
\hline 39 & PA\&E & $\begin{array}{l}\text { Kryoflex } \\
\text { Ceramic } \\
\text { Sealing } \\
\text { System }\end{array}$ & 0.00 & FC/APC & & $\begin{array}{l}\text { Single- } \\
\text { mode }\end{array}$ & & $\begin{array}{l}\text { Stainless } \\
\text { Steel }\end{array}$ & 1.00E-09 & & $-0.7 d B$ & $\begin{array}{l}\text { Feed- } \\
\text { through }\end{array}$ & & 250 & Single \\
\hline 40 & PA\&E & $\begin{array}{l}\text { Kryoflex } \\
\text { Ceramic } \\
\text { Sealing } \\
\text { System }\end{array}$ & 0.00 & FC/APC & & $\begin{array}{l}\text { Multi- } \\
\text { mode }\end{array}$ & & $\begin{array}{l}\text { Stainless } \\
\text { Steel }\end{array}$ & 1.00E-09 & & $-0.7 \mathrm{~dB}$ & $\begin{array}{l}\text { Feed- } \\
\text { through }\end{array}$ & & 250 & Single \\
\hline 41 & $\begin{array}{l}\text { Accu-Glass } \\
\text { Products }\end{array}$ & $\begin{array}{l}\text { Vacuum } \\
\text { Feed- } \\
\text { Throughs } \\
\text { with } \\
\text { Standard } \\
\text { Flanges }\end{array}$ & 635.00 & SMA & $\begin{array}{l}\text { Step- } \\
\text { Index }\end{array}$ & $\begin{array}{l}\text { Multi- } \\
\text { mode }\end{array}$ & 100 & $\begin{array}{l}\text { Stainless } \\
\text { Steel/Glass } \\
\text { Bonding }\end{array}$ & $1.00 \mathrm{E}-10$ & $\mathrm{VI} / \mathrm{NIR}$ & 0 & $\begin{array}{l}\text { Feed- } \\
\text { through }\end{array}$ & $\begin{array}{l}1.33 " \text { Con- } \\
\text { Flat } \\
\text { Flanges }\end{array}$ & 350 & Single \\
\hline 42 & $\begin{array}{l}\text { Accu-Glass } \\
\text { Products }\end{array}$ & $\begin{array}{l}\text { Vacuum } \\
\text { Feed- } \\
\text { Throughs } \\
\text { with } \\
\text { Standard } \\
\text { Flanges }\end{array}$ & 650.00 & SMA & $\begin{array}{l}\text { Step- } \\
\text { Index }\end{array}$ & $\begin{array}{l}\text { Multi- } \\
\text { mode }\end{array}$ & 100 & $\begin{array}{l}\text { Stainless } \\
\text { Steel/Glass } \\
\text { Bonding }\end{array}$ & $1.00 \mathrm{E}-10$ & $\mathrm{VI} / \mathrm{NIR}$ & 0 & $\begin{array}{l}\text { Feed- } \\
\text { through }\end{array}$ & $\begin{array}{l}2.75 " \text { Con- } \\
\text { Flat } \\
\text { Flanges }\end{array}$ & 350 & Single \\
\hline 43 & $\begin{array}{l}\text { Accu-Glass } \\
\text { Products }\end{array}$ & $\begin{array}{l}\text { Vacuum } \\
\text { Feed- } \\
\text { Throughs } \\
\text { with } \\
\text { Standard } \\
\text { Flanges }\end{array}$ & 435.00 & SMA & $\begin{array}{l}\text { Step- } \\
\text { Index }\end{array}$ & $\begin{array}{l}\text { Multi- } \\
\text { mode }\end{array}$ & 200 & $\begin{array}{l}\text { Stainless } \\
\text { Steel/Glass } \\
\text { Bonding }\end{array}$ & $1.00 \mathrm{E}-10$ & $\mathrm{VI} / \mathrm{NIR}$ & 0 & $\begin{array}{l}\text { Feed- } \\
\text { through }\end{array}$ & $\begin{array}{l}1.33 " \text { Con- } \\
\text { Flat } \\
\text { Flanges }\end{array}$ & 350 & Single \\
\hline 44 & $\begin{array}{l}\text { Accu-Glass } \\
\text { Products }\end{array}$ & $\begin{array}{l}\text { Vacuum } \\
\text { Feed- } \\
\text { Throughs } \\
\text { with } \\
\text { Standard } \\
\text { Flanges }\end{array}$ & 450.00 & SMA & $\begin{array}{l}\text { Step- } \\
\text { Index }\end{array}$ & $\begin{array}{l}\text { Multi- } \\
\text { mode }\end{array}$ & 200 & $\begin{array}{l}\text { Stainless } \\
\text { Steel/Glass } \\
\text { Bonding }\end{array}$ & $1.00 \mathrm{E}-10$ & VI/NIR & 0 & $\begin{array}{l}\text { Feed- } \\
\text { through }\end{array}$ & $\begin{array}{l}2.75 " \text { Con- } \\
\text { Flat } \\
\text { Flanges }\end{array}$ & 250 & Single \\
\hline 45 & $\begin{array}{l}\text { Accu-Glass } \\
\text { Products }\end{array}$ & $\begin{array}{l}\text { Vacuum } \\
\text { Feed- } \\
\text { Throughs } \\
\text { with } \\
\text { Standard } \\
\text { Flanges }\end{array}$ & 440.00 & SMA & $\begin{array}{l}\text { Step- } \\
\text { Index }\end{array}$ & $\begin{array}{l}\text { Multi- } \\
\text { mode }\end{array}$ & 400 & $\begin{array}{l}\text { Stainless } \\
\text { Steel/Glass } \\
\text { Bonding }\end{array}$ & $1.00 \mathrm{E}-10$ & $\mathrm{VI} / \mathrm{NIR}$ & 0 & $\begin{array}{l}\text { Feed- } \\
\text { through }\end{array}$ & $\begin{array}{l}1.33 " \text { Con- } \\
\text { Flat } \\
\text { Flanges }\end{array}$ & 350 & Single \\
\hline
\end{tabular}




\begin{tabular}{|c|c|c|c|c|c|c|c|c|c|c|c|c|c|c|c|}
\hline ID & Supplier & Brand Name & Cost & $\begin{array}{c}\text { Connector } \\
\text { Type }\end{array}$ & $\begin{array}{l}\text { Fiber } \\
\text { Profile }\end{array}$ & Mode & $\begin{array}{l}\text { Core } \\
\text { Diameter } \\
\text { (um) }\end{array}$ & $\begin{array}{c}\text { Connection } \\
\text { Material }\end{array}$ & $\begin{array}{c}\mathrm{He} \\
\text { Hermiticity } \\
\text { (cc/min) }\end{array}$ & $\begin{array}{l}\text { Expected } \\
\text { Wavelength } \\
(\mathrm{nm})\end{array}$ & $\begin{array}{l}\text { Insertion } \\
\text { Loss of } \\
\text { Inter- } \\
\text { connects } \\
\text { (dB) }\end{array}$ & $\begin{array}{l}\text { Simple } \\
\text { Feed- } \\
\text { through } \\
\text { or Pigtail }\end{array}$ & $\begin{array}{l}\text { Connector } \\
\text { Dimensions }\end{array}$ & $\begin{array}{l}\text { Possible } \\
\text { Temp } \\
\text { (C) }\end{array}$ & $\begin{array}{c}\text { Fiber\# } \\
\text { Through } \\
\text { Flange }\end{array}$ \\
\hline 46 & $\begin{array}{l}\text { Accu-Glass } \\
\text { Products }\end{array}$ & $\begin{array}{l}\text { Vacuum } \\
\text { Feed- } \\
\text { Throughs } \\
\text { with } \\
\text { Standard } \\
\text { Flanges }\end{array}$ & 455.00 & SMA & $\begin{array}{l}\text { Step- } \\
\text { Index }\end{array}$ & $\begin{array}{l}\text { Multi- } \\
\text { mode }\end{array}$ & 400 & $\begin{array}{l}\text { Stainless } \\
\text { Steel/Glass } \\
\text { Bonding }\end{array}$ & $1.00 \mathrm{E}-10$ & VI/NIR & 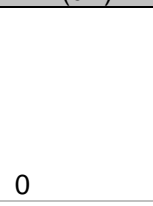 & $\begin{array}{l}\text { Feed- } \\
\text { through }\end{array}$ & $\begin{array}{l}2.75 " \text { Con- } \\
\text { Flat } \\
\text { Flanges }\end{array}$ & 350 & Single \\
\hline 47 & $\begin{array}{l}\text { Accu-Glass } \\
\text { Products }\end{array}$ & $\begin{array}{l}\text { Vacuum } \\
\text { Feed- } \\
\text { Throughs } \\
\text { with } \\
\text { Standard } \\
\text { Flanges }\end{array}$ & 450.00 & SMA & $\begin{array}{l}\text { Step- } \\
\text { Index }\end{array}$ & $\begin{array}{l}\text { Multi- } \\
\text { mode }\end{array}$ & 600 & $\begin{array}{l}\text { Stainless } \\
\text { Steel/Glass } \\
\text { Bonding }\end{array}$ & $1.00 \mathrm{E}-10$ & $\mathrm{VI} / \mathrm{NIR}$ & 0 & $\begin{array}{l}\text { Feed- } \\
\text { through }\end{array}$ & $\begin{array}{l}1.33 " \text { Con- } \\
\text { Flat } \\
\text { Flanges }\end{array}$ & & Single \\
\hline 48 & $\begin{array}{l}\text { Accu-Glass } \\
\text { Products }\end{array}$ & $\begin{array}{l}\text { Vacuum } \\
\text { Feed- } \\
\text { Throughs } \\
\text { with } \\
\text { Standard } \\
\text { Flanges }\end{array}$ & 465.00 & SMA & $\begin{array}{l}\text { Step- } \\
\text { Index }\end{array}$ & $\begin{array}{l}\text { Multi- } \\
\text { mode }\end{array}$ & 600 & $\begin{array}{l}\text { Stainless } \\
\text { Steel/Glass } \\
\text { Bonding }\end{array}$ & $1.00 \mathrm{E}-10$ & VI/NIR & 0 & $\begin{array}{l}\text { Feed- } \\
\text { through }\end{array}$ & $\begin{array}{l}2.75 " \text { Con- } \\
\text { Flat } \\
\text { Flanges }\end{array}$ & 350 & Single \\
\hline 49 & $\begin{array}{l}\text { Accu-Glass } \\
\text { Products }\end{array}$ & $\begin{array}{l}\text { Vacuum } \\
\text { Feed- } \\
\text { Throughs } \\
\text { with } \\
\text { Standard } \\
\text { Flanges }\end{array}$ & 485.00 & SMA & $\begin{array}{l}\text { Step- } \\
\text { Index }\end{array}$ & $\begin{array}{l}\text { Multi- } \\
\text { mode }\end{array}$ & 1000 & $\begin{array}{l}\text { Stainless } \\
\text { Steel/Glass } \\
\text { Bonding }\end{array}$ & $1.00 \mathrm{E}-10$ & $\mathrm{VI} / \mathrm{NIR}$ & 0 & $\begin{array}{l}\text { Feed- } \\
\text { through }\end{array}$ & $\begin{array}{l}1.33^{\prime \prime} \text { Con- } \\
\text { Flat } \\
\text { Flanges }\end{array}$ & 350 & Single \\
\hline 50 & $\begin{array}{l}\text { Accu-Glass } \\
\text { Products }\end{array}$ & $\begin{array}{l}\text { Vacuum } \\
\text { Feed- } \\
\text { Throughs } \\
\text { with } \\
\text { Standard } \\
\text { Flanges }\end{array}$ & 499.00 & SMA & $\begin{array}{l}\text { Step- } \\
\text { Index }\end{array}$ & $\begin{array}{l}\text { Multi- } \\
\text { mode }\end{array}$ & 1000 & $\begin{array}{l}\text { Stainless } \\
\text { Steel/Glass } \\
\text { Bonding }\end{array}$ & $1.00 \mathrm{E}-10$ & $\mathrm{VI} / \mathrm{NIR}$ & 0 & $\begin{array}{l}\text { Feed- } \\
\text { through }\end{array}$ & $\begin{array}{l}2.75 " \text { Con- } \\
\text { Flat } \\
\text { Flanges }\end{array}$ & 350 & Single \\
\hline 51 & $\begin{array}{l}\text { Accu-Glass } \\
\text { Products }\end{array}$ & $\begin{array}{l}\text { Vacuum } \\
\text { Feed- } \\
\text { Throughs } \\
\text { with } \\
\text { Standard } \\
\text { Flanges }\end{array}$ & $1,150.00$ & SMA & $\begin{array}{l}\text { Step- } \\
\text { Index }\end{array}$ & $\begin{array}{l}\text { Multi- } \\
\text { mode }\end{array}$ & 100 & $\begin{array}{l}\text { Stainless } \\
\text { Steel/Glass } \\
\text { Bonding }\end{array}$ & $1.00 \mathrm{E}-10$ & $\mathrm{VI} / \mathrm{NIR}$ & 0 & $\begin{array}{l}\text { Feed- } \\
\text { through }\end{array}$ & $\begin{array}{l}2.75 " \text { Con- } \\
\text { Flat } \\
\text { Flanges }\end{array}$ & 350 & Duplex \\
\hline 52 & $\begin{array}{l}\text { Accu-Glass } \\
\text { Products }\end{array}$ & $\begin{array}{l}\text { Vacuum } \\
\text { Feed- } \\
\text { Throughs } \\
\text { with } \\
\text { Standard } \\
\text { Flanges }\end{array}$ & $3,695.00$ & SMA & $\begin{array}{l}\text { Step- } \\
\text { Index }\end{array}$ & $\begin{array}{l}\text { Multi- } \\
\text { mode }\end{array}$ & 100 & $\begin{array}{l}\text { Stainless } \\
\text { Steel/Glass } \\
\text { Bonding }\end{array}$ & $1.00 \mathrm{E}-10$ & $\mathrm{VI} / \mathrm{NIR}$ & 0 & $\begin{array}{l}\text { Feed- } \\
\text { through }\end{array}$ & $\begin{array}{l}2.75 " \text { Con- } \\
\text { Flat } \\
\text { Flanges }\end{array}$ & 350 & Quad \\
\hline 53 & $\begin{array}{l}\text { Accu-Glass } \\
\text { Products }\end{array}$ & $\begin{array}{l}\text { Vacuum } \\
\text { Feed- } \\
\text { Throughs } \\
\text { with } \\
\text { Standard } \\
\text { Flanges }\end{array}$ & 790.00 & SMA & $\begin{array}{l}\text { Step- } \\
\text { Index }\end{array}$ & $\begin{array}{l}\text { Multi- } \\
\text { mode }\end{array}$ & 200 & $\begin{array}{l}\text { Stainless } \\
\text { Steel/Glass } \\
\text { Bonding }\end{array}$ & $1.00 \mathrm{E}-10$ & $\mathrm{VI} / \mathrm{NIR}$ & 0 & $\begin{array}{l}\text { Feed- } \\
\text { through }\end{array}$ & $\begin{array}{l}2.75 " \text { Con- } \\
\text { Flat } \\
\text { Flanges }\end{array}$ & 350 & Duplex \\
\hline
\end{tabular}




\begin{tabular}{|c|c|c|c|c|c|c|c|c|c|c|c|c|c|c|c|}
\hline ID & Supplier & Brand Name & Cost & $\begin{array}{c}\text { Connector } \\
\text { Type }\end{array}$ & $\begin{array}{l}\text { Fiber } \\
\text { Profile }\end{array}$ & Mode & $\begin{array}{l}\text { Core } \\
\text { Diameter } \\
\text { (um) }\end{array}$ & $\begin{array}{c}\text { Connection } \\
\text { Material }\end{array}$ & $\begin{array}{c}\mathrm{He} \\
\text { Hermiticity } \\
\text { (cc/min) }\end{array}$ & $\begin{array}{l}\text { Expected } \\
\text { Wavelength } \\
(\mathrm{nm})\end{array}$ & $\begin{array}{l}\text { Insertion } \\
\text { Loss of } \\
\text { Inter- } \\
\text { connects } \\
\text { (dB) }\end{array}$ & $\begin{array}{l}\text { Simple } \\
\text { Feed- } \\
\text { through } \\
\text { or Pigtail }\end{array}$ & $\begin{array}{l}\text { Connector } \\
\text { Dimensions }\end{array}$ & $\begin{array}{l}\text { Possible } \\
\text { Temp } \\
\text { (C) }\end{array}$ & $\begin{array}{c}\text { Fiber\# } \\
\text { Through } \\
\text { Flange }\end{array}$ \\
\hline 54 & $\begin{array}{l}\text { Accu-Glass } \\
\text { Products }\end{array}$ & $\begin{array}{l}\text { Vacuum } \\
\text { Feed- } \\
\text { Throughs } \\
\text { with } \\
\text { Standard } \\
\text { Flanges }\end{array}$ & $3,395.00$ & SMA & $\begin{array}{l}\text { Step- } \\
\text { Index }\end{array}$ & $\begin{array}{l}\text { Multi- } \\
\text { mode }\end{array}$ & 200 & $\begin{array}{l}\text { Stainless } \\
\text { Steel/Glass } \\
\text { Bonding }\end{array}$ & $1.00 \mathrm{E}-10$ & $\mathrm{VI} / \mathrm{NIR}$ & 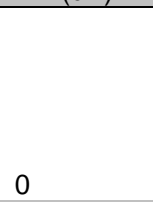 & Pigtail & $\begin{array}{l}2.75 " \text { Con- } \\
\text { Flat } \\
\text { Flanges }\end{array}$ & & Quad \\
\hline 55 & $\begin{array}{l}\text { Accu-Glass } \\
\text { Products }\end{array}$ & $\begin{array}{l}\text { Vacuum } \\
\text { Feed- } \\
\text { Throughs } \\
\text { with } \\
\text { Standard } \\
\text { Flanges }\end{array}$ & 795.00 & SMA & $\begin{array}{l}\text { Step- } \\
\text { Index }\end{array}$ & $\begin{array}{l}\text { Multi- } \\
\text { mode }\end{array}$ & 400 & $\begin{array}{l}\text { Stainless } \\
\text { Steel/Glass } \\
\text { Bonding }\end{array}$ & $1.00 \mathrm{E}-10$ & $\mathrm{VI} / \mathrm{NIR}$ & 0 & $\begin{array}{l}\text { Feed- } \\
\text { through }\end{array}$ & $\begin{array}{l}2.75 " \text { Con- } \\
\text { Flat } \\
\text { Flanges }\end{array}$ & 350 & Duplex \\
\hline 56 & $\begin{array}{l}\text { Accu-Glass } \\
\text { Products }\end{array}$ & $\begin{array}{l}\text { Vacuum } \\
\text { Feed- } \\
\text { Throughs } \\
\text { with } \\
\text { Standard } \\
\text { Flanges }\end{array}$ & $3,095.00$ & SMA & $\begin{array}{l}\text { Step- } \\
\text { Index }\end{array}$ & $\begin{array}{l}\text { Multi- } \\
\text { mode }\end{array}$ & 400 & $\begin{array}{l}\text { Stainless } \\
\text { Steel/Glass } \\
\text { Bonding }\end{array}$ & $1.00 \mathrm{E}-10$ & $\mathrm{VI} / \mathrm{NIR}$ & 0 & $\begin{array}{l}\text { Feed- } \\
\text { through }\end{array}$ & $\begin{array}{l}2.75 " \text { Con- } \\
\text { Flat } \\
\text { Flanges }\end{array}$ & 350 & Quad \\
\hline 57 & $\begin{array}{l}\text { Accu-Glass } \\
\text { Products }\end{array}$ & $\begin{array}{l}\text { Vacuum } \\
\text { Feed- } \\
\text { Throughs } \\
\text { with } \\
\text { Standard } \\
\text { Flanges }\end{array}$ & 805.00 & SMA & $\begin{array}{l}\text { Step- } \\
\text { Index }\end{array}$ & $\begin{array}{l}\text { Multi- } \\
\text { mode }\end{array}$ & 600 & $\begin{array}{l}\text { Stainless } \\
\text { Steel/Glass } \\
\text { Bonding }\end{array}$ & $1.00 \mathrm{E}-10$ & $\mathrm{VI} / \mathrm{NIR}$ & 0 & $\begin{array}{l}\text { Feed- } \\
\text { through }\end{array}$ & $\begin{array}{l}2.75 " \text { Con- } \\
\text { Flat } \\
\text { Flanges }\end{array}$ & 350 & Duplex \\
\hline 58 & $\begin{array}{l}\text { Accu-Glass } \\
\text { Products }\end{array}$ & $\begin{array}{l}\text { Vacuum } \\
\text { Feed- } \\
\text { Throughs } \\
\text { with } \\
\text { Standard } \\
\text { Flanges }\end{array}$ & $2,895.00$ & SMA & $\begin{array}{l}\text { Step- } \\
\text { Index }\end{array}$ & $\begin{array}{l}\text { Multi- } \\
\text { mode }\end{array}$ & 600 & & $1.00 \mathrm{E}-10$ & $\mathrm{VI} / \mathrm{NIR}$ & 0 & $\begin{array}{l}\text { Feed- } \\
\text { through }\end{array}$ & $\begin{array}{l}2.75 " \text { Con- } \\
\text { Flat } \\
\text { Flanges }\end{array}$ & 350 & Quad \\
\hline 59 & $\begin{array}{l}\text { Accu-Glass } \\
\text { Products }\end{array}$ & $\begin{array}{l}\text { Vacuum } \\
\text { Feed- } \\
\text { Throughs } \\
\text { with } \\
\text { Standard } \\
\text { Flanges }\end{array}$ & 875.00 & SMA & $\begin{array}{l}\text { Step- } \\
\text { Index }\end{array}$ & $\begin{array}{l}\text { Multi- } \\
\text { mode }\end{array}$ & 1000 & $\begin{array}{l}\text { Stainless } \\
\text { Steel/Glass } \\
\text { Bonding }\end{array}$ & $1.00 \mathrm{E}-10$ & VI/NIR & 0 & $\begin{array}{l}\text { Feed- } \\
\text { through }\end{array}$ & $\begin{array}{l}2.75 " \text { Con- } \\
\text { Flat } \\
\text { Flanges }\end{array}$ & 350 & Duplex \\
\hline 60 & $\begin{array}{l}\text { Accu-Glass } \\
\text { Products }\end{array}$ & $\begin{array}{l}\text { Vacuum } \\
\text { Feed- } \\
\text { Throughs } \\
\text { with } \\
\text { Standard } \\
\text { Flanges }\end{array}$ & 515.00 & SMA & $\begin{array}{l}\text { Step- } \\
\text { Index }\end{array}$ & $\begin{array}{l}\text { Multi- } \\
\text { mode }\end{array}$ & $62.5 / 125$ & $\begin{array}{l}\text { Stainless } \\
\text { Steel/Glass } \\
\text { Bonding }\end{array}$ & $1.00 \mathrm{E}-10$ & $\begin{array}{l}\text { UV/VIS or } \\
\text { VIS/NIR }\end{array}$ & 0 & $\begin{array}{l}\text { Feed- } \\
\text { through }\end{array}$ & $\begin{array}{l}\text { KF16 ISO } \\
\text { Flanges }\end{array}$ & 350 & Single \\
\hline 61 & $\begin{array}{l}\text { Accu-Glass } \\
\text { Products }\end{array}$ & $\begin{array}{l}\text { Vacuum } \\
\text { Feed- } \\
\text { Throughs } \\
\text { with } \\
\text { Standard } \\
\text { Flanges }\end{array}$ & 525.00 & SMA & $\begin{array}{l}\text { Step- } \\
\text { Index }\end{array}$ & $\begin{array}{l}\text { Multi- } \\
\text { mode }\end{array}$ & $62.5 / 125$ & $\begin{array}{l}\text { Stainless } \\
\text { Steel/Glass } \\
\text { Bonding }\end{array}$ & $1.00 \mathrm{E}-10$ & $\begin{array}{l}\text { UV/VIS or } \\
\text { VIS/NIR }\end{array}$ & 0 & $\begin{array}{l}\text { Feed- } \\
\text { through }\end{array}$ & $\begin{array}{l}\text { KF40 ISO } \\
\text { Flanges }\end{array}$ & 350 & Single \\
\hline
\end{tabular}




\begin{tabular}{|c|c|c|c|c|c|c|c|c|c|c|c|c|c|c|c|}
\hline ID & Supplier & Brand Name & Cost & $\begin{array}{c}\text { Connector } \\
\text { Type }\end{array}$ & $\begin{array}{l}\text { Fiber } \\
\text { Profile }\end{array}$ & Mode & $\begin{array}{l}\text { Core } \\
\text { Diameter } \\
\text { (um) }\end{array}$ & $\begin{array}{l}\text { Connection } \\
\text { Material }\end{array}$ & $\begin{array}{c}\mathrm{He} \\
\text { Hermiticity } \\
\text { (cc/min) }\end{array}$ & $\begin{array}{l}\text { Expected } \\
\text { Wavelength } \\
(\mathrm{nm})\end{array}$ & $\begin{array}{l}\text { Insertion } \\
\text { Loss of } \\
\text { Inter- } \\
\text { connects } \\
\text { (dB) }\end{array}$ & $\begin{array}{l}\text { Simple } \\
\text { Feed- } \\
\text { through } \\
\text { or Pigtail }\end{array}$ & $\begin{array}{l}\text { Connector } \\
\text { Dimensions }\end{array}$ & $\begin{array}{l}\text { Possible } \\
\text { Temp } \\
\text { (C) }\end{array}$ & $\begin{array}{c}\text { Fiber\# } \\
\text { Through } \\
\text { Flange }\end{array}$ \\
\hline 62 & $\begin{array}{l}\text { Accu-Glass } \\
\text { Products }\end{array}$ & $\begin{array}{l}\text { Vacuum } \\
\text { Feed- } \\
\text { Throughs } \\
\text { with } \\
\text { Standard } \\
\text { Flanges }\end{array}$ & 0.00 & SMA & $\begin{array}{l}\text { Step- } \\
\text { Index }\end{array}$ & $\begin{array}{l}\text { Multi- } \\
\text { mode }\end{array}$ & $62.5 / 125$ & $\begin{array}{l}\text { Stainless } \\
\text { Steel/Glass } \\
\text { Bonding }\end{array}$ & $1.00 \mathrm{E}-10$ & $\begin{array}{l}\text { UV/VIS or } \\
\text { VIS/NIR }\end{array}$ & 0 & $\begin{array}{l}\text { Feed- } \\
\text { through }\end{array}$ & $\begin{array}{l}\text { KF40 ISO } \\
\text { Flanges }\end{array}$ & 350 & Duplex \\
\hline 63 & $\begin{array}{l}\text { Accu-Glass } \\
\text { Products }\end{array}$ & $\begin{array}{l}\text { Vacuum } \\
\text { Feed- } \\
\text { Throughs } \\
\text { with } \\
\text { Standard } \\
\text { Flanges }\end{array}$ & 630.00 & SMA & $\begin{array}{l}\text { Step- } \\
\text { Index }\end{array}$ & $\begin{array}{l}\text { Multi- } \\
\text { mode }\end{array}$ & 100 & $\begin{array}{l}\text { Stainless } \\
\text { Steel/Glass } \\
\text { Bonding }\end{array}$ & $1.00 \mathrm{E}-10$ & VI/NIR & 0 & $\begin{array}{l}\text { Feed- } \\
\text { through }\end{array}$ & $\begin{array}{l}\text { KF16 ISO } \\
\text { Flanges }\end{array}$ & 350 & Single \\
\hline 64 & $\begin{array}{l}\text { Accu-Glass } \\
\text { Products }\end{array}$ & $\begin{array}{l}\text { Vacuum } \\
\text { Feed- } \\
\text { Throughs } \\
\text { with } \\
\text { Standard } \\
\text { Flanges }\end{array}$ & 645.00 & SMA & $\begin{array}{l}\text { Step- } \\
\text { Index }\end{array}$ & $\begin{array}{l}\text { Multi- } \\
\text { mode }\end{array}$ & 100 & $\begin{array}{l}\text { Stainless } \\
\text { Steel/Glass } \\
\text { Bonding }\end{array}$ & $1.00 \mathrm{E}-10$ & $\mathrm{VI} / \mathrm{NIR}$ & 0 & $\begin{array}{l}\text { Feed- } \\
\text { through }\end{array}$ & $\begin{array}{l}\text { KF40 ISO } \\
\text { Flanges }\end{array}$ & 350 & Single \\
\hline 65 & $\begin{array}{l}\text { Accu-Glass } \\
\text { Products }\end{array}$ & $\begin{array}{l}\text { Vacuum } \\
\text { Feed- } \\
\text { Throughs } \\
\text { with } \\
\text { Standard } \\
\text { Flanges }\end{array}$ & 0.00 & SMA & $\begin{array}{l}\text { Step- } \\
\text { Index }\end{array}$ & $\begin{array}{l}\text { Multi- } \\
\text { mode }\end{array}$ & 100 & $\begin{array}{l}\text { Stainless } \\
\text { Steel/Glass } \\
\text { Bonding }\end{array}$ & $1.00 \mathrm{E}-10$ & $\mathrm{VI} / \mathrm{NIR}$ & 0 & $\begin{array}{l}\text { Feed- } \\
\text { through }\end{array}$ & $\begin{array}{l}\text { KF40 ISO } \\
\text { Flanges }\end{array}$ & 350 & Duplex \\
\hline 66 & $\begin{array}{l}\text { Accu-Glass } \\
\text { Products }\end{array}$ & $\begin{array}{l}\text { Vacuum } \\
\text { Feed- } \\
\text { Throughs } \\
\text { with } \\
\text { Standard } \\
\text { Flanges }\end{array}$ & $3,690.00$ & SMA & $\begin{array}{l}\text { Step- } \\
\text { Index }\end{array}$ & $\begin{array}{l}\text { Multi- } \\
\text { mode }\end{array}$ & 100 & $\begin{array}{l}\text { Stainless } \\
\text { Steel/Glass } \\
\text { Bonding }\end{array}$ & $1.00 \mathrm{E}-10$ & $\mathrm{VI} / \mathrm{NIR}$ & 0 & $\begin{array}{l}\text { Feed- } \\
\text { through }\end{array}$ & $\begin{array}{l}\text { KF40 ISO } \\
\text { Flanges }\end{array}$ & 350 & Quad \\
\hline 67 & $\begin{array}{l}\text { Accu-Glass } \\
\text { Products }\end{array}$ & $\begin{array}{l}\text { Vacuum } \\
\text { Feed- } \\
\text { Throughs } \\
\text { with } \\
\text { Standard } \\
\text { Flanges }\end{array}$ & 430.00 & SMA & $\begin{array}{l}\text { Step- } \\
\text { Index }\end{array}$ & $\begin{array}{l}\text { Multi- } \\
\text { mode }\end{array}$ & 200 & $\begin{array}{l}\text { Stainless } \\
\text { Steel/Glass } \\
\text { Bonding }\end{array}$ & 1.00E-10 & $\mathrm{VI} / \mathrm{NIR}$ & 0 & $\begin{array}{l}\text { Feed- } \\
\text { through }\end{array}$ & $\begin{array}{l}\text { KF16 ISO } \\
\text { Flanges }\end{array}$ & 350 & Single \\
\hline 68 & $\begin{array}{l}\text { Accu-Glass } \\
\text { Products }\end{array}$ & $\begin{array}{l}\text { Vacuum } \\
\text { Feed- } \\
\text { Throughs } \\
\text { with } \\
\text { Standard } \\
\text { Flanges }\end{array}$ & 445.00 & SMA & $\begin{array}{l}\text { Step- } \\
\text { Index }\end{array}$ & $\begin{array}{l}\text { Multi- } \\
\text { mode }\end{array}$ & 200 & $\begin{array}{l}\text { Stainless } \\
\text { Steel/Glass } \\
\text { Bonding }\end{array}$ & $1.00 \mathrm{E}-10$ & VI/NIR & 0 & $\begin{array}{l}\text { Feed- } \\
\text { through }\end{array}$ & $\begin{array}{l}\text { KF40 ISO } \\
\text { Flanges }\end{array}$ & 350 & Single \\
\hline 69 & $\begin{array}{l}\text { Accu-Glass } \\
\text { Products }\end{array}$ & $\begin{array}{l}\text { Vacuum } \\
\text { Feed- } \\
\text { Throughs } \\
\text { with } \\
\text { Standard } \\
\text { Flanges }\end{array}$ & 0.00 & SMA & $\begin{array}{l}\text { Step- } \\
\text { Index }\end{array}$ & $\begin{array}{l}\text { Multi- } \\
\text { mode }\end{array}$ & 200 & $\begin{array}{l}\text { Stainless } \\
\text { Steel/Glass } \\
\text { Bonding }\end{array}$ & $1.00 \mathrm{E}-10$ & $\mathrm{VI} / \mathrm{NIR}$ & 0 & $\begin{array}{l}\text { Feed- } \\
\text { through }\end{array}$ & $\begin{array}{l}\text { KF40 ISO } \\
\text { Flanges }\end{array}$ & 350 & Duplex \\
\hline
\end{tabular}




\begin{tabular}{|c|c|c|c|c|c|c|c|c|c|c|c|c|c|c|c|}
\hline ID & Supplier & Brand Name & Cost & $\begin{array}{c}\text { Connector } \\
\text { Type }\end{array}$ & $\begin{array}{l}\text { Fiber } \\
\text { Profile }\end{array}$ & Mode & $\begin{array}{l}\text { Core } \\
\text { Diameter } \\
\text { (um) }\end{array}$ & $\begin{array}{l}\text { Connection } \\
\text { Material }\end{array}$ & $\begin{array}{c}\mathrm{He} \\
\text { Hermiticity } \\
\text { (cc/min) }\end{array}$ & $\begin{array}{l}\text { Expected } \\
\text { Wavelength } \\
(\mathrm{nm})\end{array}$ & $\begin{array}{l}\text { Insertion } \\
\text { Loss of } \\
\text { Inter- } \\
\text { connects } \\
\text { (dB) }\end{array}$ & $\begin{array}{l}\text { Simple } \\
\text { Feed- } \\
\text { through } \\
\text { or Pigtail }\end{array}$ & $\begin{array}{l}\text { Connector } \\
\text { Dimensions }\end{array}$ & $\begin{array}{l}\text { Possible } \\
\text { Temp } \\
\text { (C) }\end{array}$ & $\begin{array}{c}\text { Fiber\# } \\
\text { Through } \\
\text { Flange }\end{array}$ \\
\hline 70 & $\begin{array}{l}\text { Accu-Glass } \\
\text { Products }\end{array}$ & $\begin{array}{l}\text { Vacuum } \\
\text { Feed- } \\
\text { Throughs } \\
\text { with } \\
\text { Standard } \\
\text { Flanges }\end{array}$ & $3,390.00$ & SMA & $\begin{array}{l}\text { Step- } \\
\text { Index }\end{array}$ & $\begin{array}{l}\text { Multi- } \\
\text { mode }\end{array}$ & 200 & & $1.00 \mathrm{E}-10$ & VI/NIR & 0 & $\begin{array}{l}\text { Feed- } \\
\text { through }\end{array}$ & $\begin{array}{l}\text { KF40 ISO } \\
\text { Flanges }\end{array}$ & 350 & Quad \\
\hline 71 & $\begin{array}{l}\text { Accu-Glass } \\
\text { Products }\end{array}$ & $\begin{array}{l}\text { Vacuum } \\
\text { Feed- } \\
\text { Throughs } \\
\text { with } \\
\text { Standard } \\
\text { Flanges }\end{array}$ & 435.00 & SMA & $\begin{array}{l}\text { Step- } \\
\text { Index }\end{array}$ & $\begin{array}{l}\text { Multi- } \\
\text { mode }\end{array}$ & 400 & $\begin{array}{l}\text { Stainless } \\
\text { Steel/Glass } \\
\text { Bonding }\end{array}$ & $1.00 \mathrm{E}-10$ & VI/NIR & 0 & $\begin{array}{l}\text { Feed- } \\
\text { through }\end{array}$ & $\begin{array}{l}\text { KF16 ISO } \\
\text { Flanges }\end{array}$ & 350 & Single \\
\hline 72 & $\begin{array}{l}\text { Accu-Glass } \\
\text { Products }\end{array}$ & $\begin{array}{l}\text { Vacuum } \\
\text { Feed- } \\
\text { Throughs } \\
\text { with } \\
\text { Standard } \\
\text { Flanges }\end{array}$ & 0.00 & SMA & $\begin{array}{l}\text { Step- } \\
\text { Index }\end{array}$ & $\begin{array}{l}\text { Multi- } \\
\text { mode }\end{array}$ & 400 & $\begin{array}{l}\text { Stainless } \\
\text { Steel/Glass } \\
\text { Bonding }\end{array}$ & $1.00 \mathrm{E}-10$ & VI/NIR & 0 & $\begin{array}{l}\text { Feed- } \\
\text { through }\end{array}$ & $\begin{array}{l}\text { KF40 ISO } \\
\text { Flanges }\end{array}$ & 350 & Single \\
\hline 73 & $\begin{array}{l}\text { Accu-Glass } \\
\text { Products }\end{array}$ & $\begin{array}{l}\text { Vacuum } \\
\text { Feed- } \\
\text { Throughs } \\
\text { with } \\
\text { Standard } \\
\text { Flanges }\end{array}$ & 790.00 & SMA & $\begin{array}{l}\text { Step- } \\
\text { Index }\end{array}$ & $\begin{array}{l}\text { Multi- } \\
\text { mode }\end{array}$ & 400 & $\begin{array}{l}\text { Stainless } \\
\text { Steel/Glass } \\
\text { Bonding }\end{array}$ & $1.00 \mathrm{E}-10$ & VI/NIR & 0 & $\begin{array}{l}\text { Feed- } \\
\text { through }\end{array}$ & $\begin{array}{l}\text { KF40 ISO } \\
\text { Flanges }\end{array}$ & & Duplex \\
\hline 74 & $\begin{array}{l}\text { Accu-Glass } \\
\text { Products }\end{array}$ & $\begin{array}{l}\text { Vacuum } \\
\text { Feed- } \\
\text { Throughs } \\
\text { with } \\
\text { Standard } \\
\text { Flanges }\end{array}$ & $3,090.00$ & SMA & $\begin{array}{l}\text { Step- } \\
\text { Index }\end{array}$ & $\begin{array}{l}\text { Multi- } \\
\text { mode }\end{array}$ & 400 & $\begin{array}{l}\text { Stainless } \\
\text { Steel/Glass } \\
\text { Bonding }\end{array}$ & $1.00 \mathrm{E}-10$ & VI/NIR & 0 & $\begin{array}{l}\text { Feed- } \\
\text { through }\end{array}$ & $\begin{array}{l}\text { KF40 ISO } \\
\text { Flanges }\end{array}$ & 350 & Quad \\
\hline 75 & $\begin{array}{l}\text { Accu-Glass } \\
\text { Products }\end{array}$ & $\begin{array}{l}\text { Vacuum } \\
\text { Feed- } \\
\text { Throughs } \\
\text { with } \\
\text { Standard } \\
\text { Flanges }\end{array}$ & 445.00 & SMA & $\begin{array}{l}\text { Step- } \\
\text { Index }\end{array}$ & $\begin{array}{l}\text { Multi- } \\
\text { mode }\end{array}$ & 600 & $\begin{array}{l}\text { Stainless } \\
\text { Steel/Glass } \\
\text { Bonding }\end{array}$ & $1.00 \mathrm{E}-10$ & VI/NIR & 0 & $\begin{array}{l}\text { Feed- } \\
\text { through }\end{array}$ & $\begin{array}{l}\text { KF16 ISO } \\
\text { Flanges }\end{array}$ & 350 & Single \\
\hline 76 & $\begin{array}{l}\text { Accu-Glass } \\
\text { Products }\end{array}$ & $\begin{array}{l}\text { Vacuum } \\
\text { Feed- } \\
\text { Throughs } \\
\text { with } \\
\text { Standard } \\
\text { Flanges }\end{array}$ & 460.00 & SMA & $\begin{array}{l}\text { Step- } \\
\text { Index }\end{array}$ & $\begin{array}{l}\text { Multi- } \\
\text { mode }\end{array}$ & 600 & & $1.00 \mathrm{E}-10$ & VI/NIR & 0 & $\begin{array}{l}\text { Feed- } \\
\text { through }\end{array}$ & $\begin{array}{l}\text { KF40 ISO } \\
\text { Flanges }\end{array}$ & 350 & Single \\
\hline 77 & $\begin{array}{l}\text { Accu-Glass } \\
\text { Products }\end{array}$ & $\begin{array}{l}\text { Vacuum } \\
\text { Feed- } \\
\text { Throughs } \\
\text { with } \\
\text { Standard } \\
\text { Flanges }\end{array}$ & 800.00 & SMA & $\begin{array}{l}\text { Step- } \\
\text { Index }\end{array}$ & $\begin{array}{l}\text { Multi- } \\
\text { mode }\end{array}$ & 600 & $\begin{array}{l}\text { Stainless } \\
\text { Steel/Glass } \\
\text { Bonding }\end{array}$ & 1.00E-10 & VI/NIR & 0 & $\begin{array}{l}\text { Feed- } \\
\text { through }\end{array}$ & $\begin{array}{l}\text { KF40 ISO } \\
\text { Flanges }\end{array}$ & 350 & Duplex \\
\hline
\end{tabular}




\begin{tabular}{|c|c|c|c|c|c|c|c|c|c|c|c|c|c|c|c|}
\hline ID & Supplier & Brand Name & Cost & $\begin{array}{c}\text { Connector } \\
\text { Type }\end{array}$ & $\begin{array}{l}\text { Fiber } \\
\text { Profile }\end{array}$ & Mode & $\begin{array}{l}\text { Core } \\
\text { Diameter } \\
\text { (um) }\end{array}$ & $\begin{array}{c}\text { Connection } \\
\text { Material }\end{array}$ & $\begin{array}{c}\mathrm{He} \\
\text { Hermiticity } \\
\text { (cc/min) }\end{array}$ & $\begin{array}{l}\text { Expected } \\
\text { Wavelength } \\
(\mathrm{nm})\end{array}$ & $\begin{array}{l}\text { Insertion } \\
\text { Loss of } \\
\text { Inter- } \\
\text { connects } \\
\text { (dB) }\end{array}$ & $\begin{array}{l}\text { Simple } \\
\text { Feed- } \\
\text { through } \\
\text { or Pigtail }\end{array}$ & $\begin{array}{l}\text { Connector } \\
\text { Dimensions }\end{array}$ & $\begin{array}{l}\text { Possible } \\
\text { Temp } \\
\text { (C) }\end{array}$ & $\begin{array}{c}\text { Fiber\# } \\
\text { Through } \\
\text { Flange }\end{array}$ \\
\hline 78 & $\begin{array}{l}\text { Accu-Glass } \\
\text { Products }\end{array}$ & $\begin{array}{l}\text { Vacuum } \\
\text { Feed- } \\
\text { Throughs } \\
\text { with } \\
\text { Standard } \\
\text { Flanges }\end{array}$ & $2,890.00$ & SMA & $\begin{array}{l}\text { Step- } \\
\text { Index }\end{array}$ & $\begin{array}{l}\text { Multi- } \\
\text { mode }\end{array}$ & 600 & $\begin{array}{l}\text { Stainless } \\
\text { Steel/Glass } \\
\text { Bonding }\end{array}$ & $1.00 \mathrm{E}-10$ & $\mathrm{VI} / \mathrm{NIR}$ & 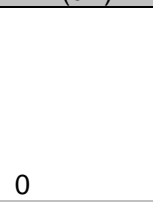 & $\begin{array}{l}\text { Feed- } \\
\text { through }\end{array}$ & $\begin{array}{l}\text { KF40 ISO } \\
\text { Flanges }\end{array}$ & 350 & Quad \\
\hline 79 & $\begin{array}{l}\text { Accu-Glass } \\
\text { Products }\end{array}$ & $\begin{array}{l}\text { Vacuum } \\
\text { Feed- } \\
\text { Throughs } \\
\text { with } \\
\text { Standard } \\
\text { Flanges }\end{array}$ & 480.00 & SMA & $\begin{array}{l}\text { Step- } \\
\text { Index }\end{array}$ & $\begin{array}{l}\text { Multi- } \\
\text { mode }\end{array}$ & 1000 & $\begin{array}{l}\text { Stainless } \\
\text { Steel/Glass } \\
\text { Bonding }\end{array}$ & $1.00 \mathrm{E}-10$ & $\mathrm{VI} / \mathrm{NIR}$ & 0 & $\begin{array}{l}\text { Feed- } \\
\text { through }\end{array}$ & $\begin{array}{l}\text { KF16 ISO } \\
\text { Flanges }\end{array}$ & 350 & Single \\
\hline 80 & $\begin{array}{l}\text { Accu-Glass } \\
\text { Products }\end{array}$ & $\begin{array}{l}\text { Vacuum } \\
\text { Feed- } \\
\text { Throughs } \\
\text { with } \\
\text { Standard } \\
\text { Flanges }\end{array}$ & 495.00 & SMA & $\begin{array}{l}\text { Step- } \\
\text { Index }\end{array}$ & $\begin{array}{l}\text { Multi- } \\
\text { mode }\end{array}$ & 1000 & $\begin{array}{l}\text { Stainless } \\
\text { Steel/Glass } \\
\text { Bonding }\end{array}$ & $1.00 \mathrm{E}-10$ & VI/NIR & 0 & $\begin{array}{l}\text { Feed- } \\
\text { through }\end{array}$ & $\begin{array}{l}\text { KF40 ISO } \\
\text { Flanges }\end{array}$ & 350 & Single \\
\hline 81 & $\begin{array}{l}\text { Accu-Glass } \\
\text { Products }\end{array}$ & $\begin{array}{l}\text { Vacuum } \\
\text { Feed- } \\
\text { Throughs } \\
\text { with } \\
\text { Standard } \\
\text { Flanges }\end{array}$ & 870.00 & SMA & $\begin{array}{l}\text { Step- } \\
\text { Index }\end{array}$ & $\begin{array}{l}\text { Multi- } \\
\text { mode }\end{array}$ & 1000 & $\begin{array}{l}\text { Stainless } \\
\text { Steel/Glass } \\
\text { Bonding }\end{array}$ & $1.00 \mathrm{E}-10$ & VI/NIR & 0 & $\begin{array}{l}\text { Feed- } \\
\text { through }\end{array}$ & $\begin{array}{l}\text { KF40 ISO } \\
\text { Flanges }\end{array}$ & 350 & Duplex \\
\hline 82 & $\begin{array}{l}\text { Accu-Glass } \\
\text { Products }\end{array}$ & $\begin{array}{l}\text { Vacuum } \\
\text { Feed- } \\
\text { Throughs } \\
\text { with } \\
\text { Standard } \\
\text { Flanges }\end{array}$ & 630.00 & SMA & $\begin{array}{l}\text { Step- } \\
\text { Index }\end{array}$ & $\begin{array}{l}\text { Multi- } \\
\text { mode }\end{array}$ & 100 & $\begin{array}{l}\text { Stainless } \\
\text { Steel/Glass } \\
\text { Bonding }\end{array}$ & $1.00 \mathrm{E}-10$ & UV or VIS & 0 & $\begin{array}{l}\text { Feed- } \\
\text { through }\end{array}$ & $\begin{array}{l}\text { KF16 ISO } \\
\text { Flanges }\end{array}$ & 350 & Single \\
\hline 83 & $\begin{array}{l}\text { Accu-Glass } \\
\text { Products }\end{array}$ & $\begin{array}{l}\text { Vacuum } \\
\text { Feed- } \\
\text { Throughs } \\
\text { with } \\
\text { Standard } \\
\text { Flanges }\end{array}$ & 645.00 & SMA & $\begin{array}{l}\text { Step- } \\
\text { Index }\end{array}$ & $\begin{array}{l}\text { Multi- } \\
\text { mode }\end{array}$ & 100 & & $1.00 \mathrm{E}-10$ & UV or VIS & 0 & $\begin{array}{l}\text { Feed- } \\
\text { through }\end{array}$ & $\begin{array}{l}\text { KF40 ISO } \\
\text { Flanges }\end{array}$ & 350 & Single \\
\hline 84 & $\begin{array}{l}\text { Accu-Glass } \\
\text { Products }\end{array}$ & $\begin{array}{l}\text { Vacuum } \\
\text { Feed- } \\
\text { Throughs } \\
\text { with } \\
\text { Standard } \\
\text { Flanges }\end{array}$ & $1,140.00$ & SMA & $\begin{array}{l}\text { Step- } \\
\text { Index }\end{array}$ & $\begin{array}{l}\text { Multi- } \\
\text { mode }\end{array}$ & 100 & $\begin{array}{l}\text { Stainless } \\
\text { Steel/Glass } \\
\text { Bonding }\end{array}$ & $1.00 \mathrm{E}-10$ & UV or VIS & 0 & $\begin{array}{l}\text { Feed- } \\
\text { through }\end{array}$ & $\begin{array}{l}\text { KF40 ISO } \\
\text { Flanges }\end{array}$ & 350 & Duplex \\
\hline 85 & $\begin{array}{l}\text { Accu-Glass } \\
\text { Products }\end{array}$ & $\begin{array}{l}\text { Vacuum } \\
\text { Feed- } \\
\text { Throughs } \\
\text { with } \\
\text { Standard } \\
\text { Flanges }\end{array}$ & 645.00 & SMA & $\begin{array}{l}\text { Step- } \\
\text { Index }\end{array}$ & $\begin{array}{l}\text { Multi- } \\
\text { mode }\end{array}$ & 100 & $\begin{array}{l}\text { Stainless } \\
\text { Steel/Glass } \\
\text { Bonding }\end{array}$ & $1.00 \mathrm{E}-10$ & UV or VIS & 0 & $\begin{array}{l}\text { Feed- } \\
\text { through }\end{array}$ & $\begin{array}{l}\text { KF40 ISO } \\
\text { Flanges }\end{array}$ & 350 & Quad \\
\hline
\end{tabular}




\begin{tabular}{|c|c|c|c|c|c|c|c|c|c|c|c|c|c|c|c|}
\hline ID & Supplier & Brand Name & Cost & $\begin{array}{c}\text { Connector } \\
\text { Type }\end{array}$ & $\begin{array}{l}\text { Fiber } \\
\text { Profile }\end{array}$ & Mode & $\begin{array}{l}\text { Core } \\
\text { Diameter } \\
\text { (um) }\end{array}$ & $\begin{array}{c}\text { Connection } \\
\text { Material }\end{array}$ & $\begin{array}{c}\mathrm{He} \\
\text { Hermiticity } \\
\text { (cc/min) }\end{array}$ & $\begin{array}{l}\text { Expected } \\
\text { Wavelength } \\
(\mathrm{nm})\end{array}$ & $\begin{array}{l}\text { Insertion } \\
\text { Loss of } \\
\text { Inter- } \\
\text { connects } \\
\text { (dB) }\end{array}$ & $\begin{array}{l}\text { Simple } \\
\text { Feed- } \\
\text { through } \\
\text { or Pigtail }\end{array}$ & $\begin{array}{l}\text { Connector } \\
\text { Dimensions }\end{array}$ & $\begin{array}{l}\text { Possible } \\
\text { Temp } \\
\text { (C) }\end{array}$ & $\begin{array}{c}\text { Fiber\# } \\
\text { Through } \\
\text { Flange }\end{array}$ \\
\hline 86 & $\begin{array}{l}\text { Accu-Glass } \\
\text { Products }\end{array}$ & $\begin{array}{l}\text { Vacuum } \\
\text { Feed- } \\
\text { Throughs } \\
\text { with } \\
\text { Standard } \\
\text { Flanges }\end{array}$ & 430.00 & SMA & $\begin{array}{l}\text { Step- } \\
\text { Index }\end{array}$ & $\begin{array}{l}\text { Multi- } \\
\text { mode }\end{array}$ & 200 & $\begin{array}{l}\text { Stainless } \\
\text { Steel/Glass } \\
\text { Bonding }\end{array}$ & $1.00 \mathrm{E}-10$ & UV or VIS & 0 & $\begin{array}{l}\text { Feed- } \\
\text { through }\end{array}$ & $\begin{array}{l}\text { KF16 ISO } \\
\text { Flanges }\end{array}$ & 350 & Single \\
\hline 87 & $\begin{array}{l}\text { Accu-Glass } \\
\text { Products }\end{array}$ & $\begin{array}{l}\text { Vacuum } \\
\text { Feed- } \\
\text { Throughs } \\
\text { with } \\
\text { Standard } \\
\text { Flanges }\end{array}$ & 445.00 & SMA & $\begin{array}{l}\text { Step- } \\
\text { Index }\end{array}$ & $\begin{array}{l}\text { Multi- } \\
\text { mode }\end{array}$ & 200 & $\begin{array}{l}\text { Stainless } \\
\text { Steel/Glass } \\
\text { Bonding }\end{array}$ & $1.00 \mathrm{E}-10$ & UV or VIS & 0 & $\begin{array}{l}\text { Feed- } \\
\text { through }\end{array}$ & $\begin{array}{l}\text { KF40 ISO } \\
\text { Flanges }\end{array}$ & & Single \\
\hline 88 & $\begin{array}{l}\text { Accu-Glass } \\
\text { Products }\end{array}$ & $\begin{array}{l}\text { Vacuum } \\
\text { Feed- } \\
\text { Throughs } \\
\text { with } \\
\text { Standard } \\
\text { Flanges }\end{array}$ & $7,850.00$ & SMA & $\begin{array}{l}\text { Step- } \\
\text { Index }\end{array}$ & $\begin{array}{l}\text { Multi- } \\
\text { mode }\end{array}$ & 200 & $\begin{array}{l}\text { Stainless } \\
\text { Steel/Glass } \\
\text { Bonding }\end{array}$ & $1.00 \mathrm{E}-10$ & UV or VIS & 0 & $\begin{array}{l}\text { Feed- } \\
\text { through }\end{array}$ & $\begin{array}{l}\text { KF40 ISO } \\
\text { Flanges }\end{array}$ & 350 & Duplex \\
\hline 89 & $\begin{array}{l}\text { Accu-Glass } \\
\text { Products }\end{array}$ & $\begin{array}{l}\text { Vacuum } \\
\text { Feed- } \\
\text { Throughs } \\
\text { with } \\
\text { Standard } \\
\text { Flanges }\end{array}$ & 445.00 & SMA & $\begin{array}{l}\text { Step- } \\
\text { Index }\end{array}$ & $\begin{array}{l}\text { Multi- } \\
\text { mode }\end{array}$ & 200 & $\begin{array}{l}\text { Stainless } \\
\text { Steel/Glass } \\
\text { Bonding }\end{array}$ & $1.00 \mathrm{E}-10$ & UV or VIS & 0 & $\begin{array}{l}\text { Feed- } \\
\text { through }\end{array}$ & $\begin{array}{l}\text { KF40 ISO } \\
\text { Flanges }\end{array}$ & 350 & Quad \\
\hline 90 & $\begin{array}{l}\text { Accu-Glass } \\
\text { Products }\end{array}$ & $\begin{array}{l}\text { Vacuum } \\
\text { Feed- } \\
\text { Throughs } \\
\text { with } \\
\text { Standard } \\
\text { Flanges }\end{array}$ & 435.00 & SMA & $\begin{array}{l}\text { Step- } \\
\text { Index }\end{array}$ & $\begin{array}{l}\text { Multi- } \\
\text { mode }\end{array}$ & 400 & $\begin{array}{l}\text { Stainless } \\
\text { Steel/Glass } \\
\text { Bonding }\end{array}$ & $1.00 \mathrm{E}-10$ & UV or VIS & 0 & $\begin{array}{l}\text { Feed- } \\
\text { through }\end{array}$ & $\begin{array}{l}\text { KF16 ISO } \\
\text { Flanges }\end{array}$ & 350 & Single \\
\hline 91 & $\begin{array}{l}\text { Accu-Glass } \\
\text { Products }\end{array}$ & $\begin{array}{l}\text { Vacuum } \\
\text { Feed- } \\
\text { Throughs } \\
\text { with } \\
\text { Standard } \\
\text { Flanges }\end{array}$ & 450.00 & SMA & $\begin{array}{l}\text { Step- } \\
\text { Index }\end{array}$ & & 400 & $\begin{array}{l}\text { Stainless } \\
\text { Steel/Glass } \\
\text { Bonding }\end{array}$ & $1.00 \mathrm{E}-10$ & UV or VIS & 0 & $\begin{array}{l}\text { Feed- } \\
\text { through }\end{array}$ & $\begin{array}{l}\text { KF40 ISO } \\
\text { Flanges }\end{array}$ & 350 & Single \\
\hline 92 & $\begin{array}{l}\text { Accu-Glass } \\
\text { Products }\end{array}$ & $\begin{array}{l}\text { Vacuum } \\
\text { Feed- } \\
\text { Throughs } \\
\text { with } \\
\text { Standard } \\
\text { Flanges }\end{array}$ & 790.00 & SMA & $\begin{array}{l}\text { Step- } \\
\text { Index }\end{array}$ & $\begin{array}{l}\text { Multi- } \\
\text { mode }\end{array}$ & 400 & $\begin{array}{l}\text { Stainless } \\
\text { Steel/Glass } \\
\text { Bonding }\end{array}$ & $1.00 \mathrm{E}-10$ & UV or VIS & 0 & $\begin{array}{l}\text { Feed- } \\
\text { through }\end{array}$ & $\begin{array}{l}\text { KF40 ISO } \\
\text { Flanges }\end{array}$ & 350 & Duplex \\
\hline 93 & $\begin{array}{l}\text { Accu-Glass } \\
\text { Products }\end{array}$ & $\begin{array}{l}\text { Vacuum } \\
\text { Feed- } \\
\text { Throughs } \\
\text { with } \\
\text { Standard } \\
\text { Flanges }\end{array}$ & $3,090.00$ & SMA & $\begin{array}{l}\text { Step- } \\
\text { Index }\end{array}$ & $\begin{array}{l}\text { Multi- } \\
\text { mode }\end{array}$ & 400 & $\begin{array}{l}\text { Stainless } \\
\text { Steel/Glass } \\
\text { Bonding }\end{array}$ & $1.00 \mathrm{E}-10$ & UV or VIS & 0 & $\begin{array}{l}\text { Feed- } \\
\text { through }\end{array}$ & $\begin{array}{l}\text { KF40 ISO } \\
\text { Flanges }\end{array}$ & 350 & Quad \\
\hline
\end{tabular}




\begin{tabular}{|c|c|c|c|c|c|c|c|c|c|c|c|c|c|c|c|}
\hline ID & Supplier & Brand Name & Cost & $\begin{array}{c}\text { Connector } \\
\text { Type }\end{array}$ & $\begin{array}{l}\text { Fiber } \\
\text { Profile }\end{array}$ & Mode & $\begin{array}{c}\text { Core } \\
\text { Diameter } \\
\text { (um) }\end{array}$ & $\begin{array}{c}\text { Connection } \\
\text { Material }\end{array}$ & $\begin{array}{c}\mathrm{He} \\
\text { Hermiticity } \\
\text { (cc/min) }\end{array}$ & $\begin{array}{c}\text { Expected } \\
\text { Wavelength } \\
(\mathrm{nm})\end{array}$ & $\begin{array}{l}\text { Insertion } \\
\text { Loss of } \\
\text { Inter- } \\
\text { connects } \\
\text { (dB) }\end{array}$ & $\begin{array}{l}\text { Simple } \\
\text { Feed- } \\
\text { through } \\
\text { or Pigtail }\end{array}$ & $\begin{array}{l}\text { Connector } \\
\text { Dimensions }\end{array}$ & $\begin{array}{l}\text { Possible } \\
\text { Temp } \\
\text { (C) }\end{array}$ & $\begin{array}{c}\text { Fiber\# } \\
\text { Through } \\
\text { Flange } \\
\end{array}$ \\
\hline 94 & $\begin{array}{l}\text { Accu-Glass } \\
\text { Products }\end{array}$ & $\begin{array}{l}\text { Vacuum } \\
\text { Feed- } \\
\text { Throughs } \\
\text { with } \\
\text { Standard } \\
\text { Flanges }\end{array}$ & 445.00 & SMA & $\begin{array}{l}\text { Step- } \\
\text { Index }\end{array}$ & $\begin{array}{l}\text { Multi- } \\
\text { mode }\end{array}$ & 600 & $\begin{array}{l}\text { Stainless } \\
\text { Steel/Glass } \\
\text { Bonding }\end{array}$ & $1.00 \mathrm{E}-10$ & UV or VIS & 0 & $\begin{array}{l}\text { Feed- } \\
\text { through }\end{array}$ & $\begin{array}{l}\text { KF16 ISO } \\
\text { Flanges }\end{array}$ & 350 & Single \\
\hline 95 & $\begin{array}{l}\text { Accu-Glass } \\
\text { Products }\end{array}$ & $\begin{array}{l}\text { Vacuum } \\
\text { Feed- } \\
\text { Throughs } \\
\text { with } \\
\text { Standard } \\
\text { Flanges }\end{array}$ & 460.00 & SMA & $\begin{array}{l}\text { Step- } \\
\text { Index }\end{array}$ & $\begin{array}{l}\text { Multi- } \\
\text { mode }\end{array}$ & 600 & $\begin{array}{l}\text { Stainless } \\
\text { Steel/Glass } \\
\text { Bonding }\end{array}$ & $1.00 \mathrm{E}-10$ & UV or VIS & 0 & $\begin{array}{l}\text { Feed- } \\
\text { through }\end{array}$ & $\begin{array}{l}\text { KF40 ISO } \\
\text { Flanges }\end{array}$ & 350 & Single \\
\hline 96 & $\begin{array}{l}\text { Accu-Glass } \\
\text { Products }\end{array}$ & $\begin{array}{l}\text { Vacuum } \\
\text { Feed- } \\
\text { Throughs } \\
\text { with } \\
\text { Standard } \\
\text { Flanges }\end{array}$ & 800.00 & SMA & $\begin{array}{l}\text { Step- } \\
\text { Index }\end{array}$ & $\begin{array}{l}\text { Multi- } \\
\text { mode }\end{array}$ & 600 & $\begin{array}{l}\text { Stainless } \\
\text { Steel/Glass } \\
\text { Bonding }\end{array}$ & 1.00E-10 & UV or VIS & 0 & $\begin{array}{l}\text { Feed- } \\
\text { through }\end{array}$ & $\begin{array}{l}\text { KF40 ISO } \\
\text { Flanges }\end{array}$ & 350 & Duplex \\
\hline 97 & $\begin{array}{l}\text { Accu-Glass } \\
\text { Products }\end{array}$ & $\begin{array}{l}\text { Vacuum } \\
\text { Feed- } \\
\text { Throughs } \\
\text { with } \\
\text { Standard } \\
\text { Flanges }\end{array}$ & $2,890.00$ & SMA & $\begin{array}{l}\text { Step- } \\
\text { Index }\end{array}$ & $\begin{array}{l}\text { Multi- } \\
\text { mode }\end{array}$ & 600 & $\begin{array}{l}\text { Stainless } \\
\text { Steel/Glass } \\
\text { Bonding }\end{array}$ & $1.00 \mathrm{E}-10$ & UV or VIS & 0 & $\begin{array}{l}\text { Feed- } \\
\text { through }\end{array}$ & $\begin{array}{l}\text { KF40 ISO } \\
\text { Flanges }\end{array}$ & 350 & Quad \\
\hline 98 & $\begin{array}{l}\text { Accu-Glass } \\
\text { Products }\end{array}$ & $\begin{array}{l}\text { Vacuum } \\
\text { Feed- } \\
\text { Throughs } \\
\text { with } \\
\text { Standard } \\
\text { Flanges }\end{array}$ & 480.00 & SMA & $\begin{array}{l}\text { Step- } \\
\text { Index }\end{array}$ & $\begin{array}{l}\text { Multi- } \\
\text { mode }\end{array}$ & 1000 & $\begin{array}{l}\text { Stainless } \\
\text { Steel/Glass } \\
\text { Bonding }\end{array}$ & $1.00 \mathrm{E}-10$ & UV or VIS & 0 & $\begin{array}{l}\text { Feed- } \\
\text { through }\end{array}$ & $\begin{array}{l}\text { KF16 ISO } \\
\text { Flanges }\end{array}$ & 350 & Single \\
\hline 99 & $\begin{array}{l}\text { Accu-Glass } \\
\text { Products }\end{array}$ & $\begin{array}{l}\text { Vacuum } \\
\text { Feed- } \\
\text { Throughs } \\
\text { with } \\
\text { Standard } \\
\text { Flanges }\end{array}$ & 495.00 & SMA & $\begin{array}{l}\text { Step- } \\
\text { Index }\end{array}$ & $\begin{array}{l}\text { Multi- } \\
\text { mode }\end{array}$ & 1000 & $\begin{array}{l}\text { Stainless } \\
\text { Steel/Glass } \\
\text { Bonding }\end{array}$ & $1.00 \mathrm{E}-10$ & UV or VIS & 0 & $\begin{array}{l}\text { Feed- } \\
\text { through }\end{array}$ & $\begin{array}{l}\text { KF40 ISO } \\
\text { Flanges }\end{array}$ & 350 & Single \\
\hline 100 & $\begin{array}{l}\text { Accu-Glass } \\
\text { Products }\end{array}$ & $\begin{array}{l}\text { Vacuum } \\
\text { Feed- } \\
\text { Throughs } \\
\text { with } \\
\text { Standard } \\
\text { Flanges }\end{array}$ & 870.00 & SMA & $\begin{array}{l}\text { Step- } \\
\text { Index }\end{array}$ & $\begin{array}{l}\text { Multi- } \\
\text { mode }\end{array}$ & 1000 & $\begin{array}{l}\text { Stainless } \\
\text { Steel/Glass } \\
\text { Bonding }\end{array}$ & $1.00 \mathrm{E}-10$ & UV or VIS & 0 & $\begin{array}{l}\text { Feed- } \\
\text { through }\end{array}$ & $\begin{array}{l}\text { KF40 ISO } \\
\text { Flanges }\end{array}$ & 350 & Duplex \\
\hline
\end{tabular}




\section{Appendix B}

Fiber Optic Sensor Shock and Vibration Data 


\begin{tabular}{|c|c|c|c|c|c|c|c|c|c|c|}
\hline & & \multicolumn{3}{|c|}{$100 \mathrm{G}$} & \multicolumn{3}{|c|}{$220 \mathrm{G}$} & \multicolumn{3}{|c|}{$400 \mathrm{G}$} \\
\hline & & $\mathrm{x}$ & $\mathrm{Y}$ & $\bar{Z}$ & $\mathrm{x}$ & $\bar{Y}$ & $\bar{Z}$ & $x$ & $\mathrm{Y}$ & $\bar{Z}$ \\
\hline \multirow[t]{2}{*}{ OpSens } & Temperature $\left({ }^{\circ} \mathrm{C}\right)$ & 23.60 & 24.10 & 22.60 & 21.20 & 23.70 & 23.20 & 21.40 & 21.60 & 22.90 \\
\hline & Temperature $\left({ }^{\circ} \mathrm{F}\right)$ & 74.48 & 75.38 & 72.68 & 70.16 & 74.66 & 73.76 & 70.52 & 70.88 & 73.22 \\
\hline \multirow{2}{*}{ Neoptix } & Temperature $\left({ }^{\circ} \mathrm{C}\right)$ & 25.80 & 25.90 & 24.60 & 23.20 & 25.60 & 25.20 & 23.30 & 23.70 & 24.80 \\
\hline & Temperature $\left({ }^{\circ} \mathrm{F}\right)$ & 78.44 & 78.62 & 76.28 & 73.76 & 78.08 & 77.36 & 73.94 & 74.66 & 76.64 \\
\hline \multirow[t]{2}{*}{ Fiso } & Temperature $2505\left({ }^{\circ} \mathrm{F}\right)$ & 74.10 & 74.90 & 72.20 & 69.50 & 73.70 & 73.30 & 69.90 & 70.20 & 72.60 \\
\hline & Strain $91601(\mathrm{PSI})$ & -0.25 & -0.25 & -0.25 & -0.15 & -0.20 & -0.20 & -0.20 & -0.20 & -0.25 \\
\hline \multicolumn{2}{|r|}{ Temperature $\left({ }^{\circ} \mathrm{F}\right)$} & 22.10 & 24.10 & 21.00 & 21.20 & 24.80 & 23.10 & 22.10 & 22.40 & 24.70 \\
\hline \multirow{2}{*}{ STOA } & P143877 (uW) & 10,23 & 1133 & 12.04 & 10.43 & 11.87 & 1199 & 1166 & 1194 & 11.26 \\
\hline & P143892 (uW) & 10.43 & 10.63 & 11.21 & 9.70 & 11.37 & 11.39 & 11.82 & 11.63 & 10.80 \\
\hline \multirow{2}{*}{$\begin{array}{l}\text { Accu-Glass Feed-through } \\
\text { (21.5 uW) }\end{array}$} & High Vacuum Bolt & $79.49 \%$ & $83.78 \%$ & $86.13 \%$ & $85.05 \%$ & $80.36 \%$ & $85.77 \%$ & $89.13 \%$ & $1540.00 \%$ & $1650.00 \%$ \\
\hline & Ultrahigh Vacuum CF Flange & $92.50 \%$ & $89.19 \%$ & $91.36 \%$ & $89.18 \%$ & $87.66 \%$ & $=17.21 / ? ? ?$ & $96.74 \%$ & $86.67 \%$ & $91.79 \%$ \\
\hline
\end{tabular}

\begin{tabular}{|c|c|c|c|c|c|c|c|c|c|c|}
\hline MMTOA (1) & TOP & & & & & & & & & \\
\hline & $\begin{array}{lc}\text { channel } 1 \\
\end{array}$ & 5.62 & 5.27 & 5.42 & 5.67 & 5.23 & 5.06 & 5.48 & 5.54 & 4.88 \\
\hline & channel 2 & 4.45 & 4.39 & 4.59 & 4.57 & 4.20 & 4.11 & 4.39 & 4.32 & 3.91 \\
\hline & channel 3 & 0.00 & 4.81 & 5.05 & 5.10 & 4.42 & 4.49 & 4.71 & 4.73 & 4.18 \\
\hline & channel 4 & 4.31 & 4.25 & 4.30 & 4.31 & 3.55 & 3.49 & 3.71 & 3.77 & 3.46 \\
\hline & channel 5 & 4.76 & 4.57 & 4.70 & 4.68 & 3.88 & 3.72 & 3.93 & 4.03 & 3.82 \\
\hline & channel 6 & 5.90 & 5.78 & 6.00 & 5.95 & 4.65 & 4.49 & 4.86 & 4.92 & 4.60 \\
\hline & channel 7 & 6.29 & 6.22 & 6.40 & 6.41 & 4.28 & 4.52 & 4.84 & 5.01 & 4.50 \\
\hline & channel 8 & 5.99 & 5.99 & 5.99 & 5.99 & 4.25 & 4.52 & 4.77 & 4.84 & 4.45 \\
\hline & channel 9 & 6.59 & 6.41 & 6.78 & 6.48 & 4.31 & 4.50 & 4.83 & 4.76 & 4.40 \\
\hline & channel 10 & 5.83 & 5.83 & 5.83 & 5.83 & 4.14 & 4.42 & 4.63 & 4.72 & 4.41 \\
\hline & channel 11 & 7.13 & 7.01 & 7.22 & 7.36 & 4.11 & 4.51 & 4.73 & 4.66 & 4.29 \\
\hline & channel 12 & 5.92 & 5.92 & 5.92 & 5.92 & 4.01 & 4.23 & 4.34 & 4.47 & 4.11 \\
\hline
\end{tabular}

\begin{tabular}{|c|c|c|c|c|c|c|c|c|c|c|}
\hline MMTOA (2) & BOTTOM & & & & & & & & & \\
\hline & channel 1 & 1.80 & 1.82 & 1.78 & 1.82 & 1.87 & 1.82 & 1.71 & 1.70 & 1.65 \\
\hline & channel 2 & 1.54 & 1.55 & 1.54 & 1.57 & 1.57 & 1.61 & 1.52 & 1.52 & 1.46 \\
\hline & channel 3 & 1.37 & 1.40 & 1.40 & 1.39 & 1.41 & 1.45 & 1.38 & 1.33 & 1.29 \\
\hline & channel 4 & 1.71 & 1.81 & 1.76 & 1.73 & 1.75 & 1.75 & 1.66 & 1.63 & 1.62 \\
\hline & channel 5 & 1.55 & 1.64 & 1.59 & 1.63 & 1.68 & 1.66 & 1.54 & 1.56 & 1.53 \\
\hline & channel 6 & 1.54 & 1.57 & 1.51 & 1.55 & 1.57 & 1.51 & 1.40 & 1.43 & 1.44 \\
\hline & channel 7 & 1.44 & 1.37 & 1.42 & 1.43 & 1.45 & 1.42 & 1.37 & 1.34 & 1.32 \\
\hline & channel 8 & 1.43 & 1.36 & 1.42 & 1.44 & 1.44 & 1.40 & 1.35 & 1.32 & 1.33 \\
\hline & channel 9 & 1.41 & 1.35 & 1.42 & 1.46 & 1.50 & 1.38 & 1.32 & 1.33 & 1.35 \\
\hline & channel 10 & 1.64 & 1.59 & 1.56 & 1.61 & 1.67 & 1.57 & 1.46 & 1.53 & 1.44 \\
\hline & channel 11 & 1.63 & 1.57 & 1.58 & 1.66 & 1.61 & 1.50 & 1.43 & 1.46 & 1.42 \\
\hline & channel 12 & 1.67 & 1.59 & 1.61 & 1.63 & 1.65 & 1.57 & 1.53 & 1.51 & 1.47 \\
\hline
\end{tabular}




\begin{tabular}{|c|c|c|c|c|c|c|c|c|c|c|}
\hline & & \multicolumn{3}{|c|}{$800 \mathrm{G}$} & \multicolumn{3}{|c|}{$1500 \mathrm{G}$} & \multicolumn{3}{|c|}{$2200 \mathrm{G}$} \\
\hline & & $\mathrm{X}$ & $\mathrm{Y}$ & Z & $\mathrm{X}$ & $\mathrm{Y}$ & $\mathrm{Z}$ & $\mathrm{X}$ & $\mathrm{Y}$ & $\mathrm{Z}$ \\
\hline \multirow[t]{2}{*}{ OpSens } & Temperature $\left({ }^{\circ} \mathrm{C}\right)$ & 23.70 & 24.00 & 23.80 & 24.20 & 24.40 & 24.30 & 23.00 & 22.60 & 23.30 \\
\hline & Temperature $\left({ }^{\circ} \mathrm{F}\right)$ & 74.66 & 75.20 & 74.84 & 75.56 & 75.92 & 75.74 & 73.40 & 72.68 & 73.94 \\
\hline \multirow[t]{2}{*}{ Neoptix } & Temperature $\left({ }^{\circ} \mathrm{C}\right)$ & 25.20 & 25.50 & 25.20 & 25.60 & 25.80 & 25.80 & 24.50 & 23.90 & 24.90 \\
\hline & Temperature $\left({ }^{\circ} \mathrm{F}\right)$ & 77.36 & 77.90 & 77.36 & 78.08 & 78.44 & 78.44 & 76.10 & 75.02 & 76.82 \\
\hline \multirow[t]{2}{*}{ Fiso } & Temperature $2505\left({ }^{\circ} \mathrm{F}\right)$ & 73.00 & 73.80 & 73.40 & 73.90 & 74.50 & 74.40 & 72.10 & 71.60 & 72.50 \\
\hline & Strain 91601 (PSI) & -0.10 & -0.10 & -0.15 & -0.15 & -0.15 & -0.15 & -0.05 & -0.05 & -0.05 \\
\hline \multicolumn{2}{|r|}{ Temperature $\left({ }^{\circ} \mathrm{F}\right)$} & 33.20 & 47.00 & 44.00 & 46.90 & 53.00 & 27.10 & -32.70 & 62.30 & -0.40 \\
\hline \multirow[t]{2}{*}{ STOA } & $\mathrm{P} 143877(\mathrm{uW})$ & 9.40 & 12.62 & 11.20 & 10.86 & 10.99 & 10.43 & 11.00 & 12.14 & 12.28 \\
\hline & P143892 (uW) & 9.48 & 13.12 & 10.30 & 11.40 & 10.28 & 9.94 & 11.75 & 11.52 & 12.54 \\
\hline \multirow{2}{*}{$\begin{array}{c}\text { Accu-Glass Feed-through } \\
(21.5 \mathrm{uW})\end{array}$} & High Vacuum Bolt & BROKEN & - & - & - & - & - & - & - & - \\
\hline & Ultrahigh Vacuum CF Flange & $88.83 \%$ & $85.18 \%$ & $92.86 \%$ & $91.02 \%$ & $88.55 \%$ & $91.28 \%$ & $89.64 \%$ & $84.72 \%$ & $91.36 \%$ \\
\hline
\end{tabular}

\begin{tabular}{|c|c|c|c|c|c|c|c|c|c|c|}
\hline MMTOA (1) & TOP & & & & & & & & & \\
\hline & channel 1 & 6.33 & 6.21 & 5.05 & 5.65 & 6.49 & 6.00 & 6.28 & 5.95 & 6.07 \\
\hline & channel 2 & 4.90 & 5.04 & 3.94 & 4.50 & 4.99 & 4.82 & 4.90 & 4.87 & 4.73 \\
\hline & channel 3 & Dead Switch & - & - & - & - & - & - & - & - \\
\hline & channel 4 & 4.02 & 4.08 & 3.32 & 3.79 & 4.13 & 4.19 & 4.26 & 4.11 & 4.25 \\
\hline & channel 5 & 4.43 & 4.50 & 3.61 & 3.90 & 4.73 & 4.41 & 4.66 & 4.45 & 4.72 \\
\hline & channel 6 & 5.27 & 5.40 & 4.34 & 4.86 & 5.37 & 5.21 & 5.42 & 5.32 & 5.32 \\
\hline & channel 7 & 5.51 & 5.51 & 4.37 & 4.94 & 5.40 & 5.24 & 5.56 & 5.18 & 5.53 \\
\hline & channel 8 & 5.30 & 5.40 & 4.14 & 4.80 & 5.26 & 5.22 & 5.50 & 5.34 & 5.33 \\
\hline & channel 9 & 5.38 & 5.44 & 4.23 & 4.73 & 5.06 & 5.03 & 5.43 & 5.02 & 4.96 \\
\hline & channel 10 & 5.22 & 5.22 & 4.12 & 4.44 & 4.95 & 4.91 & 5.30 & 5.21 & 5.15 \\
\hline & channel 11 & 5.23 & 5.37 & 4.10 & 4.50 & 4.96 & 4.95 & 5.27 & 5.07 & 5.14 \\
\hline & channel 12 & 4.93 & 5.07 & 3.94 & 4.36 & 4.65 & 4.80 & 5.17 & 4.93 & 4.83 \\
\hline \multirow[t]{14}{*}{ MMTOA (2) } & BOTTOM & & & & & & & & & \\
\hline & channel 1 & 1.91 & 1.88 & 1.70 & 1.90 & 1.94 & 1.88 & 1.96 & 1.92 & 1.92 \\
\hline & channel 2 & 1.65 & 1.69 & 1.52 & 1.70 & 1.70 & 1.66 & 1.69 & 1.69 & 1.71 \\
\hline & channel 3 & 1.50 & 1.48 & 1.43 & 1.49 & 1.55 & 1.47 & 1.53 & 1.49 & 1.59 \\
\hline & channel 4 & 1.81 & 1.76 & 1.62 & 1.83 & 1.82 & 1.80 & 1.87 & 1.78 & 1.86 \\
\hline & channel 5 & 1.64 & 1.66 & 1.67 & 1.67 & 1.73 & 1.70 & 1.75 & 1.70 & 1.70 \\
\hline & channel 6 & 1.58 & 1.57 & 1.48 & 1.58 & 1.62 & 1.56 & 1.61 & 1.59 & 1.61 \\
\hline & channel 7 & 1.48 & 1.49 & 1.31 & 1.51 & 1.52 & 1.48 & 1.54 & 1.50 & 1.53 \\
\hline & channel 8 & 1.45 & 1.42 & 1.32 & 1.49 & 1.51 & 1.45 & 1.53 & 1.43 & 1.52 \\
\hline & channel 9 & 1.45 & 1.45 & 1.27 & 1.47 & 1.50 & 1.46 & 1.50 & 1.46 & 1.49 \\
\hline & channel 10 & 1.64 & 1.54 & 1.44 & 1.60 & 1.68 & 1.56 & 1.70 & 1.63 & 1.67 \\
\hline & channel 11 & 1.61 & 1.52 & 1.46 & 1.65 & 1.59 & 1.54 & 1.66 & 1.63 & 1.64 \\
\hline & channel 12 & 1.65 & 1.64 & 1.54 & 1.63 & 1.67 & 1.67 & 1.70 & 1.71 & 1.71 \\
\hline & & & & & & & & & & \\
\hline
\end{tabular}




\begin{tabular}{|c|c|c|c|c|c|c|c|c|c|c|}
\hline & & \multicolumn{3}{|c|}{$3300 \mathrm{G}$} & \multicolumn{3}{|c|}{$4000 \mathrm{G}$} & \multicolumn{3}{|c|}{$5000 \mathrm{G}$} \\
\hline & & $x$ & $\mathrm{Y}$ & Z & $x$ & $\mathrm{Y}$ & $\mathrm{Z}$ & $\mathrm{x}$ & $\mathrm{Y}$ & Z \\
\hline \multirow[t]{2}{*}{ OpSens } & Temperature $\left({ }^{\circ} \mathrm{C}\right)$ & 23.10 & 23.50 & 23.70 & 22.70 & 23.20 & 23.60 & 23.70 & 23.60 & 23.50 \\
\hline & Temperature $\left({ }^{\circ} \mathrm{F}\right)$ & 73.58 & 74.30 & 74.66 & 72.86 & 73.76 & 74.48 & 74.66 & 74.48 & 74.30 \\
\hline \multirow[t]{2}{*}{ Neoptix } & Temperature $\left({ }^{\circ} \mathrm{C}\right)$ & 25.20 & 25.20 & 25.40 & 24.40 & 24.80 & 24.00 & 25.00 & 25.10 & 24.90 \\
\hline & Temperature $\left({ }^{\circ} \mathrm{F}\right)$ & 77.36 & 77.36 & 77.72 & 75.92 & 76.64 & 75.20 & 77.00 & 77.18 & 76.82 \\
\hline \multirow[t]{2}{*}{ Fiso } & Temperature $2505\left({ }^{\circ} \mathrm{F}\right)$ & 72.60 & 73.30 & 73.40 & 71.90 & 72.40 & 72.70 & 72.90 & 73.30 & 72.70 \\
\hline & Strain 91601 (PSI) & -0.10 & -0.10 & -0.10 & -0.05 & -0.05 & -0.05 & -0.05 & -0.05 & -0.05 \\
\hline \multicolumn{2}{|r|}{ Temperature $\left({ }^{\circ} \mathrm{F}\right)$} & -8.70 & -24.50 & 22.90 & 22.20 & -19.90 & -1.00 & 7.10 & 45.70 & 58.90 \\
\hline \multirow[t]{2}{*}{ STOA } & P143877 (uW) & 11.25 & 11.38 & 11.31 & 8.61 & 5.41 & 2.45 & 2.13 & 3.21 & cannot test \\
\hline & P143892 (uW) & 11.02 & 10.34 & 10.93 & 8.36 & 6.07 & 2.18 & 2.23 & 3.34 & cannot test \\
\hline \multirow{2}{*}{$\begin{array}{l}\text { Accu-Glass Feed-through } \\
(21.5 \mathrm{uW}) \\
\end{array}$} & High Vacuum Bolt & - & - & - & - & - & - & - & - & - \\
\hline & Ultrahigh Vacuum CF Flange & $92.74 \%$ & $93.21 \%$ & $90.74 \%$ & $90.43 \%$ & $90.68 \%$ & $91.29 \%$ & $91.05 \%$ & $90.60 \%$ & $90.50 \%$ \\
\hline \multirow[t]{13}{*}{ MMTOA (1) } & TOP & & & & & & & & & open circuit \\
\hline & channel 1 & 5.82 & 5.76 & 5.65 & Failed & - & - & - & - & - \\
\hline & channel 2 & 4.76 & 4.66 & 4.62 & 4.42 & 2.50 & 0.85 & 0.86 & - & - \\
\hline & channel 3 & - & - & - & - & - & - & - & - & - \\
\hline & channel 4 & 3.93 & 4.15 & 3.93 & 4.02 & 2.50 & 0.55 & 0.61 & 0.69 & - \\
\hline & channel 5 & 4.36 & 4.37 & 4.22 & 4.52 & 1.72 & 0.75 & 0.83 & 0.92 & - \\
\hline & channel 6 & 5.16 & 5.24 & 5.13 & 5.27 & 3.26 & 1.06 & 1.06 & 1.15 & - \\
\hline & channel 7 & 5.16 & 5.31 & 5.14 & 5.24 & 2.90 & 1.16 & 1.16 & 1.31 & - \\
\hline & channel 8 & 5.01 & 5.18 & 5.10 & 5.06 & 3.36 & 1.16 & 1.20 & 1.35 & - \\
\hline & channel 9 & 4.81 & 4.73 & 4.82 & 4.75 & 2.79 & 1.03 & 1.06 & 1.14 & - \\
\hline & channel 10 & 5.01 & 4.95 & 4.98 & 5.04 & 3.01 & 1.15 & 1.22 & 1.29 & - \\
\hline & channel 11 & 4.99 & 4.99 & 4.88 & 5.06 & 3.07 & 1.26 & 1.37 & 1.46 & - \\
\hline & channel 12 & 4.62 & 4.91 & 4.64 & 5.01 & 1.28 & 1.32 & 1.31 & 1.32 & - \\
\hline \multirow[t]{13}{*}{ MMTOA (2) } & BOTTOM & & & & & & & open circuit & & 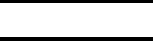 \\
\hline & channel 1 & 1.90 & 1.87 & 1.93 & 1.92 & 1.86 & 1.90 & - & - & - \\
\hline & channel 2 & 1.65 & 1.66 & 1.75 & - & - & - & - & - & - \\
\hline & channel 3 & 1.50 & 1.49 & 1.56 & 1.54 & 1.36 & 1.44 & - & - & - \\
\hline & channel 4 & 1.80 & 1.84 & 1.88 & 1.85 & 1.77 & 1.82 & - & - & - \\
\hline & channel 5 & 1.75 & 1.76 & 1.80 & 1.78 & 1.70 & 1.75 & - & - & - \\
\hline & channel 6 & 1.61 & 1.65 & 1.66 & 1.69 & 1.62 & 1.65 & - & - & - \\
\hline & channel 7 & 1.58 & 1.53 & 1.59 & 1.58 & 1.56 & 1.56 & - & - & - \\
\hline & channel 8 & 1.53 & 1.51 & 1.55 & 1.60 & 1.54 & 1.55 & - & - & - \\
\hline & channel 9 & 1.54 & 1.53 & 1.54 & 1.59 & 1.56 & 1.60 & - & - & - \\
\hline & channel 10 & 1.69 & 1.72 & 1.75 & 1.73 & 1.67 & 1.73 & - & - & - \\
\hline & channel 11 & 1.65 & 1.67 & 1.65 & 1.66 & 1.66 & 1.31 & - & - & - \\
\hline & channel 12 & 1.72 & 1.68 & 1.72 & 1.75 & 1.73 & 1.80 & - & - & - \\
\hline
\end{tabular}

